15 k

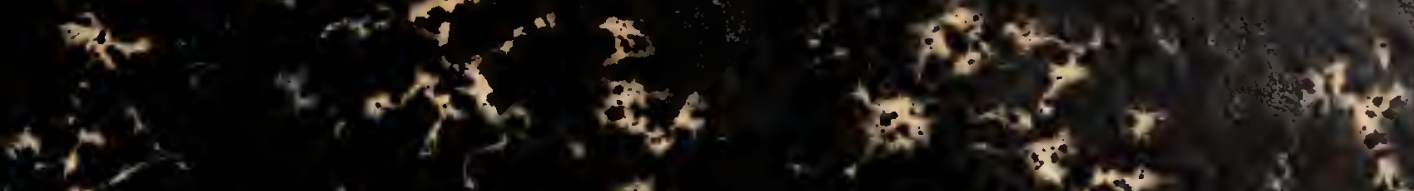

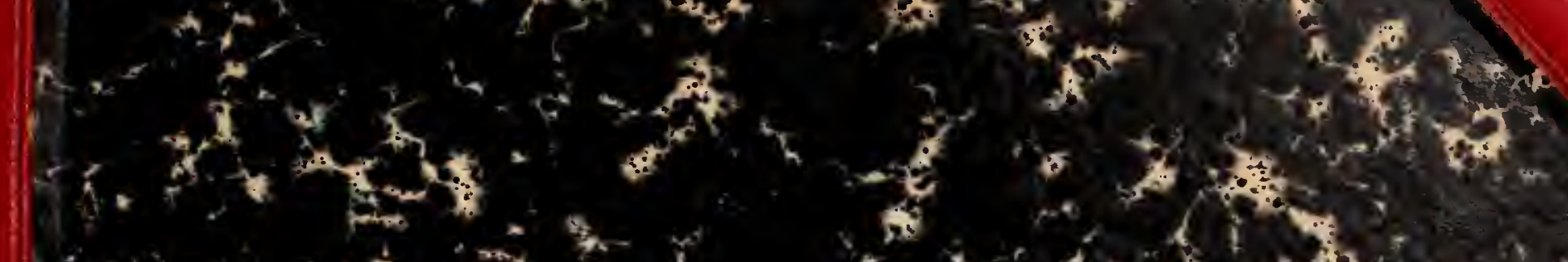

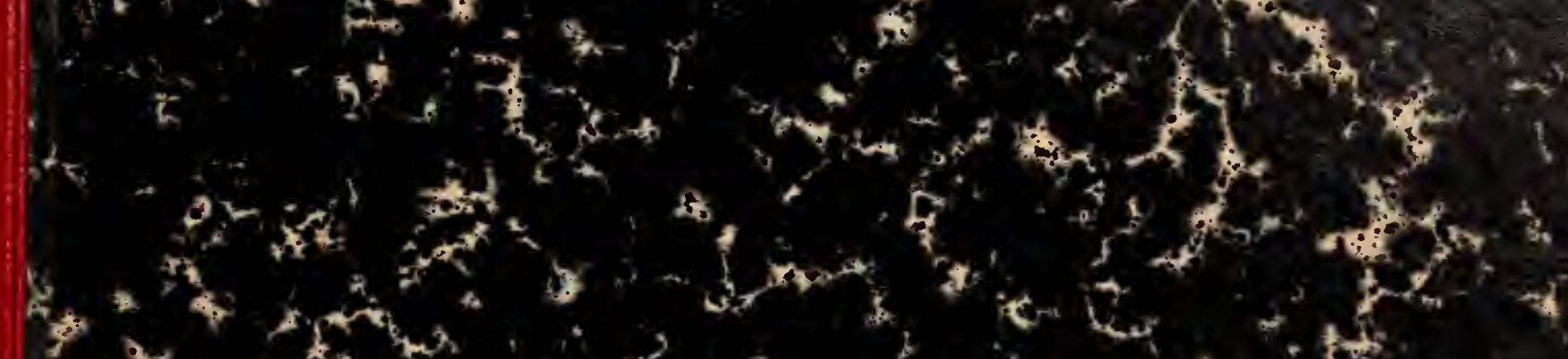

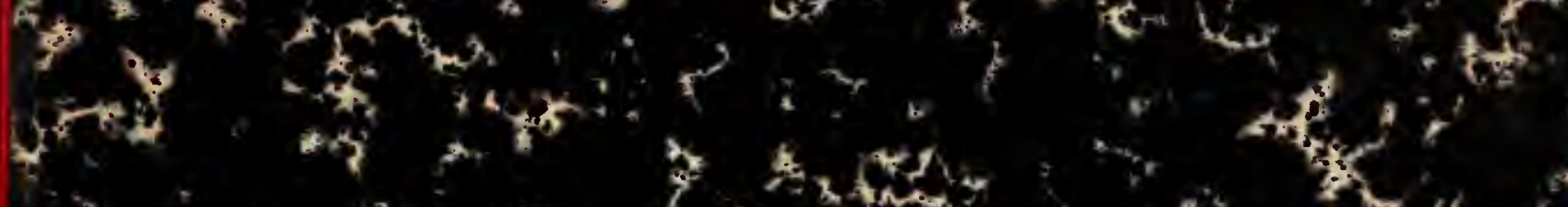

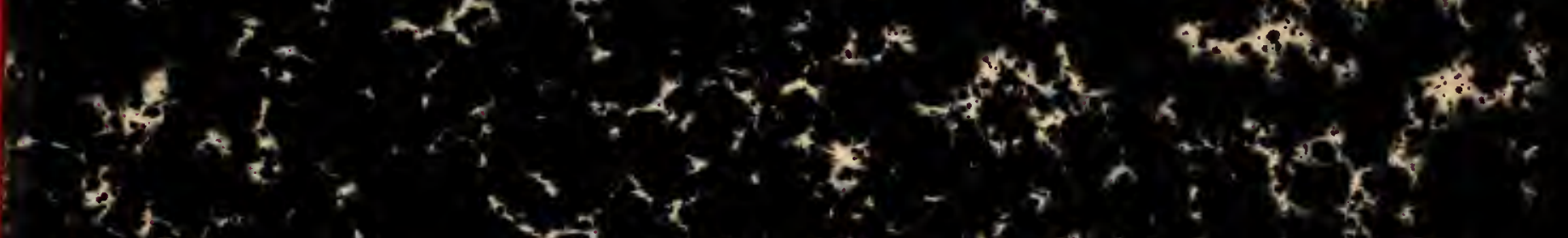

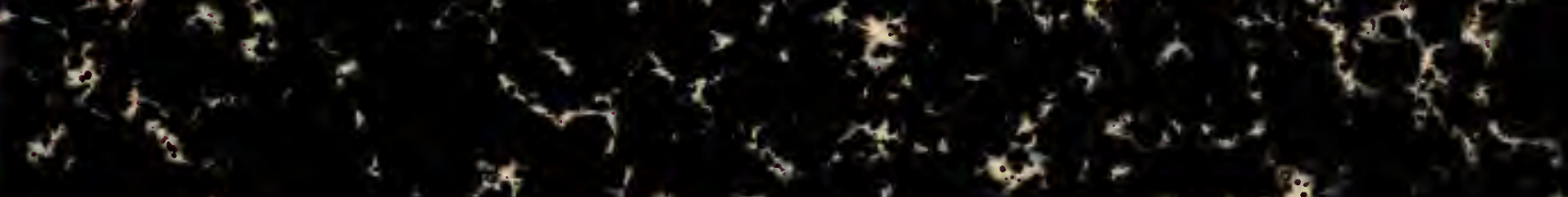

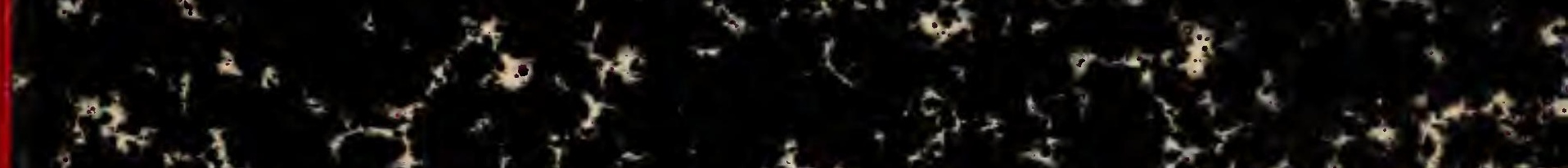



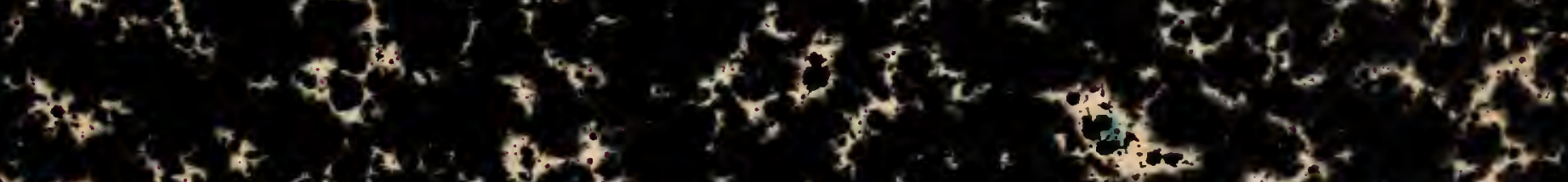



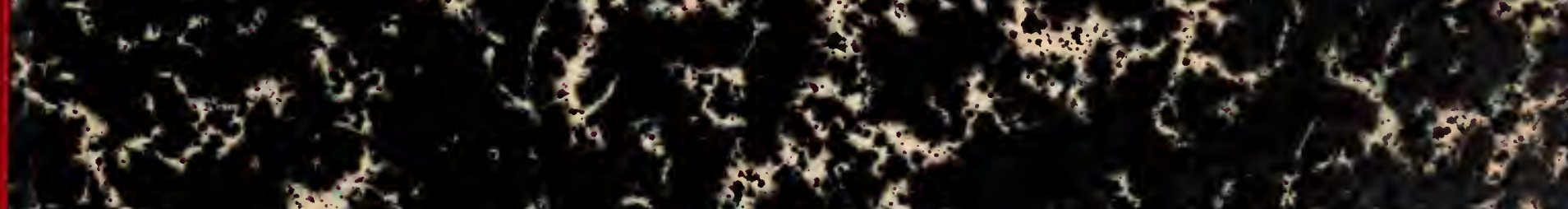

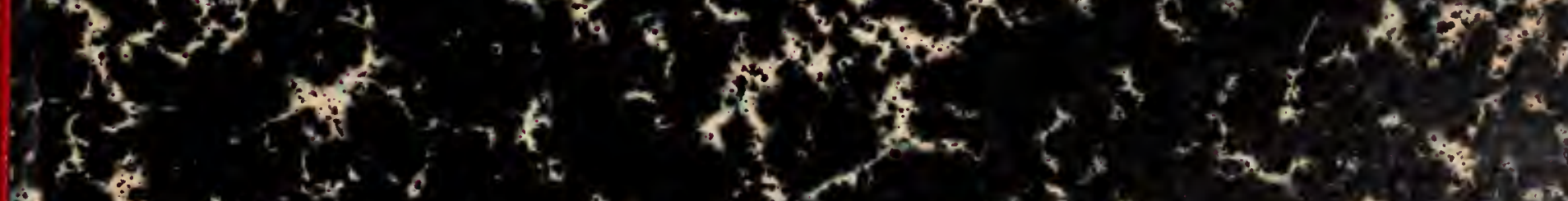

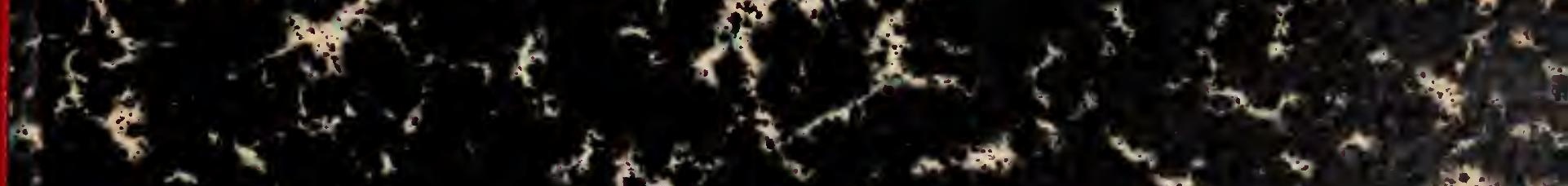

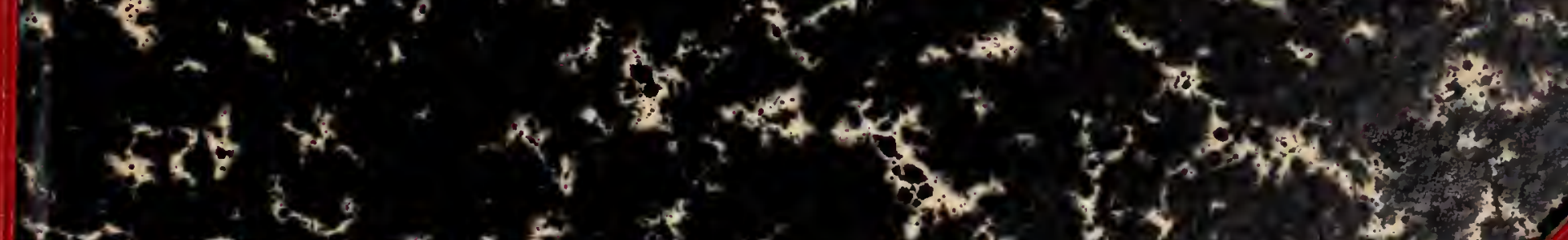

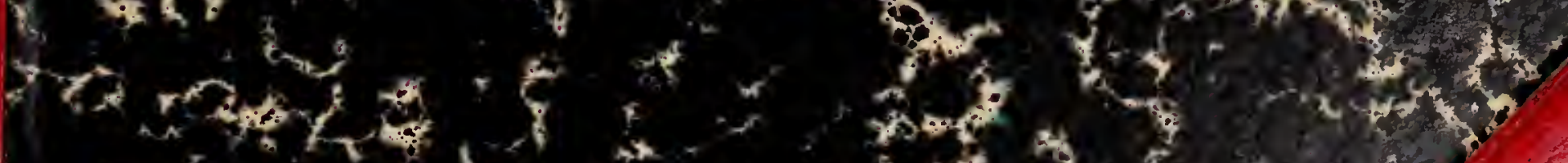

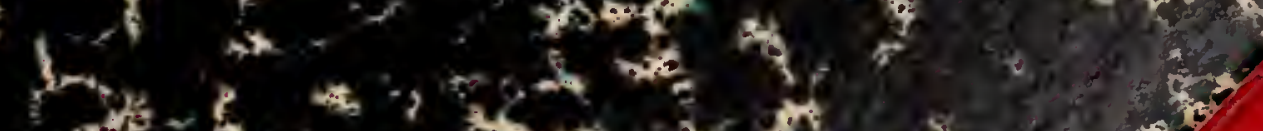

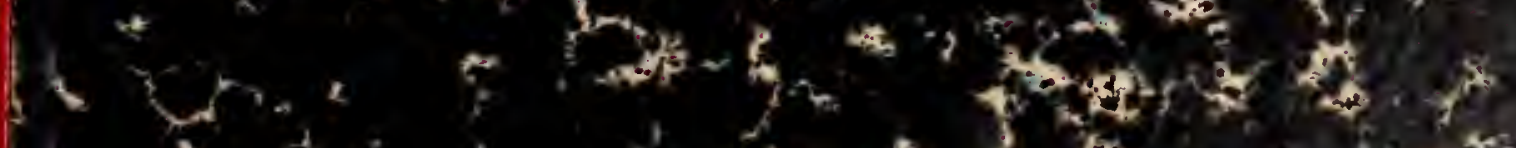


HARVARD UNIVERSITY

है

Library of the

Museum of

Comparative Zoology 



\section{MEMOIRS}

OF THE

IIUSEUN OF COMPARATIVE Z00̈LOGY

AT

\section{HARVARD COLLEGE.}

VOL. XXIX.

CAMBRIDGE, U.S.A.

PRINTED FOR THE MUSEUM.

1903. 



\section{MEMOIRS}

OF THE

\section{MUSEUM OF COMPARATIVE Z00̈LOGY \\ AT}

\section{HARVARD COLLEGE.}

VOL. XXIX.

CAMBRIDGE, U.S.A.

PRINTED FOR THE MUSEUM.

1903. 
University Press :

John Wilson and Son, Cambridge, U.S. A. 


\section{O N T E T S.}

Tile CORal ReEFs of the Maldives. By Alexander Agassiz. pp. i-xxv, 1-168. 82 Plates. December, 1903.

One Volume Text. One Volume Plates. 



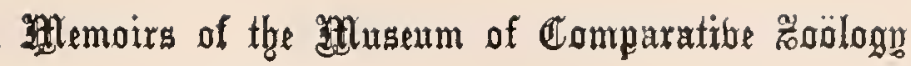 \\ AT HARVARD COLLEGE. \\ VoL. XXIX.
}

\section{THE CORAL REEFS OF THE MALDIVES.}

\author{
BY ALEXANDER AGASSIZ.
}

WITH EIGHTY-TWO PLATES.

TEXT.

CAMBRIDGE, U.S.A.:

俰inted for the fusum.

DeCEMBER, 1903. 


\section{TABLE OF CONTENTS.}

Introduction . . . . . . . . . . . . . . . . . . . Page ix

Hrdrography of the Maldives. Plates 1-8 c . . . . . . . . . . . 1

TOpography of the Indian Ocean Wegt of Malabar. Plates 7,8 . . . . 5

Analysis of the Soundings taken by the "Amra." Plates 1-8 c . . . . . 12

List of Soundings . . . . . . . . . . . . . . . . . . . . . . 29

Description of the Atolls:

North Male. Plates $1,3,4 ; 8$ a, fig. $6 ; 8$ b, figs. 11,$19 ; 8$ c, fig. $24 ; 9-18 ; 19$, fig. 135

Gaha Faro. Plates 1,$3 ; 8$ a, figs. 6,$8 ; 8$ b, fig. 11 . . . . . . . . . . . 53

Goifurfehendu. Plates 1,$3 ; 8$ a, fig. $8 ; 8$ b, fig. $10 ; 19$, fig. $2 ; 20$. . . . . . 54

Karidu. Plates 1,$3 ; 8$ b, fig. $11 ; 21$. . . . . . . . . . . . . . . 55

Malosmadulu Plateau. Plates 1,$3 ; 8$ a, fig. $5 ; 8$ b, figs. 9, 10; 8 c, fig. 28; 22-30;

31 , fig. 1 . . . . . . . . . . . . . . . . . . . . . . . . 56

South Malosmadulu. Plates 1,$3 ; 8$ b, fig. $10 ; 8 \mathrm{c}$, fig. 28; 22-28; 29, fig. 2 . . 59

Middle Malosmadulu. Plates 1,$3 ; 8$ b, figs. 9,$10 ; 29$, fig. 1 . : . . . . 64

North Malosmadulu. Plates 1,$3 ; 8$ a, fig. $5 ; 8$ b, fig. $9 ; 8$ c, fig. $26 ; 30 ; 31$, fig. 165

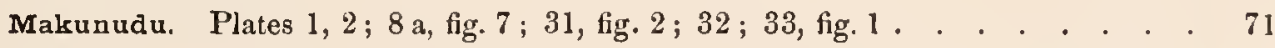

Fadiffolu. Plates 1,$3 ; 8$ a, fig. $4 ; 8$ b, fig. $11 ; 8$ c, fig. $28 ; 33$, fig. $2 ; \cdot 34$, fig. 1 . 73

Tiladummati-Miladummadulu Plateau. Plates $1,2,3 ; 8$ a, figs. 2-5, 7; 34, fig. 2;

$35-53 ; 79$, fig. 3 . . . . . . . . . . . . . . . . . . . . . 78

Miladummadulu. Plates $1,2,3 ; 8$ a, figs. $4,5,7 ; 34$, fig. $2 ; 35-44 ; 79$, fig. 3 . 83

Tiladummati. Plates 1,$2 ; 8$ a, figs. 2,$3 ; 45-53$. . . . . . . . . . . . 93

Ihavandiff ulu. Plates 1,$2 ; 8$ a, figs. 1,$3 ; 54,55$, fig. 1 . . . . . . . . . 100

Toddu. Plates 1, 4. . . . . . . . . . . . . . . . . 102

Rasdu. Plates 1,4 . . . . . . . . . . . . . . . . . . 102

Ari. Plates 1,$4 ; 8$ b, figs. 12,$14 ; 8$ c, fig. $25 ; 55$, fig. $2 ; 56,57,58$, fig. 2 . . 103

North Nilandu. Plates $1,4,5 ; 8$ b, fig. $14 ; 59-61 ; 78$, fig. 1 . . . . . . 107

South Nilandu. Plates 1,$5 ; 8$ b, figs. 13,$17 ; 62,63,64$, fig. $2 ; 78$, fig. 2 . . 110

South Male. Plates 1, 4; 8 b, figs. 12,$16 ; 8$ c, figs. 19,$27 ; 79$, fig. 2 . . . 113

Felidu. Plates $1,4,5 ; 8$ b, figs. 15,16 . . . . . . . . . . . . 114

Wataru Reef. Plates 1,$5 ; 8$ b, fig. $15 ; 58$, fig. 1 . . . . . . . . 118

Mulaku. Plates 1, 5; 8 b, figs. 13, 15, 18; 64, fig. 1;65 . . . . . . . . . 118

Kolumadulu. Plates 1, 5; 8 b, figs. 17,$18 ; 8 \mathrm{c}$, fig. $20 ; 66$. . . . . . . 122

Haddummati. Plates 1,$6 ; 8 \mathrm{c}$, figs. 20,$22 ; 67-70,77$, fig. 1 . . . . . . . . 127

Suvadiva. Plates 1,$6 ; 8 \mathrm{c}$, figs. 22,$23 ; 71-75 ; 79$, fig. 1 . . . . . . . 134 
Description of the Atolls (Continued): Page

Fua Mulaku. Plates 1,$6 ; 8 \mathrm{c}$, fig. 23 . . . . . . . . . . . . 145

Addu. Plates 1,$6 ; 8 \mathrm{c}$, figs. 21,$23 ; 76,77$, fig. 2 . . . . . . . . 145

Temperature of the Lagoons . . . . . . . . . . . . . . . . . 149

Вотtom Deposits in the Lagoons . . . . . . . . . . . . . . . . . 152

The Pelagic Fauna of the Maldives . . . . . . . . . . . . . . 155

$\operatorname{INDEX}$. . . . . . . . . . . . . . . . . . . 161 


\section{IN T R O D U C T I O N.}

IT had always been my intention, on the completion of my explorations of the atoll and coral regions of the Pacific, to make an expedition to the Maldives, the only great group of atolls I had not visited, and which promised interesting results; the coral reefs of the Maldives differing radically, according to the charts, from every region I had examined.' We spent part of December, 1901, and Jannary, 1902, in exploring the Maldives.

The steamer "Amra," chartered from the British India Steam Navigation Company, proved a most serviceable vessel for examining the coral reefs of the Maldives. ${ }^{2}$ She was commanded by Captain William Pigott, R.N.R., who proved himself a most careful navigator among the maze of atolls through which we steamed for over sixteen hundred miles. Both he and the officers of the "Amra" showed the greatest interest in the objects of the Expedition. Captain Pigott took charge of the sounding machine, and himself superintended all the soundings we took (more than eighty in number); he becime exceeringly skilful at this work. Several of the deeper soundings were taken successfully under most trying circumstances. The "Amra" was equipped with a deep-sea Lucas sounding machine built for me by the Telegraph Construction and Maintenance Company of London. The machine differs radically from the American type of sounding machine developed by Captain Sigsbee with which I was familiar, and which I had in commission on all my former expeditions.

1 This is the last of the series of monographs I shall publish on Coral Reefs, and I hope, as soon as practicable, to give a résumé and connected acconnt of the results obtained during my expeditions to all the important coral regions of the Atlantic, Pacific, and Indian Oceans.

2 A sketch of the work of the Experlition was published at Colombo in the "Observer," January 29, 1902, and in the American Journal of Science for March of the same year. 
Excellent as is the Sigsbee machine, the Lucas sounder has some advantages in its compactness, it being self-contained and practically automatic. But its greatest advantage lies in the use of malleable wire for sounding in place of the hard-drawn wire in use in American machines. This greatly simplifies the rnaking of splices and lessens immensely the danger of kinking while handling the wire. We had in addition a Sir William Thomson sounding machine for moderate depths in the lagoons or at our anchorages. I also placed on board a steam winch of the Bacon pattern with a drum large enough to hold six hundred to eight hundred fathoms of wire dredging rope. This winch was used for deep-sea towing down to one hundred and fifty fathoms and for the few hauls of the dredge we found time to take.

Dr. W. MclI. Woodworth, my son Maximilian, and Mr. H. B. Bigelow accompanied me as assistants. My son and Dr. Woodworth took a large number of photograplis. Dr. Woodworth had general charge of the collections. They were intentionally limited, as we could not hope in the short time at our command to add much to the material obtained by Mr. J. Stanley Gardiner during his prolonged stay at the Maldives and Laccadives. Mr. Bigelow collected thirty species of Medusae, interesting mainly for the geographical distribution of the genera represented. As might be expected, they were principally Hydroids, exclusive of the Siphonophores, Discophores, and Ctenophores. The pelagic Fauna was at times very rich, and some of our deeper hanls were most productive. The surface hauls inside the lagoons were also frequently very rich, far more than in the lagoons of any other coral-reef region I have visited. This may be accounted for from the open condition of the lagoons of the composite atolls of the Maldives. No attempt was made to collect any plants, the collections of Mr. Gardiner having supplied the material for an exhaustive list of the Flora of the Maldives. ${ }^{1}$

Messrs. Willis and Gardiner have published a most interesting account of the Flora of the Maldives and of Minikoi based upon the extensive collections made by Mr. Gardiner. They have made a careful analysis of the flora,

1 The Botany of the Maldive Islands, by J. C. Willis and J. Stanley Gardiner, Ann. Royal Botanic Gardens, Peradeniya, Vol. I., Part II., December, 1901. 
showing the sources from which it has been derived and the manner in which it has reached the islands. Messrs. Willis and Gardiner consider the flora of the islands to be recent, and that if the Maldives "were now to be submerged and to rise again above the waves, they would probably accuire in time a flora almost identical with that which they now possess." 1 They look upon the effect of oceanic currents as the most important of all the agencies in stocking oceanic islands.

To the eonsiderable direct trade which exists between the Malabar Coast, Calcutta, and Male is probably due the introduction of many Indian weeds ${ }^{2}$ and a large number of cultivated plants and trees. At Huludu (Addu) there are also "traditions of an Arabian trade in times past." 3 The natives of Tiladummati and Ihavandiffuln are most enterprising, and they have undoubtedly introduced a number of plants and trees in the northern groups of the Archipelago. For an archipelago with such active traders, the agency of man has undoubtedly been an effective factor in modifying the flora of the group and in introducing many plants and trees both from India and Arabia. It was interesting to watch the native ships taking advantage of the shetter of the islands to beat northward against the northeast monsoon in comparatively smooth water, until they reached Ihavandiffulu and could fetch the southern coast of India and Ceylon.

In discussing the origin of the flora of other oceanic islands of the Indian Ocean, Messrs. Willis and Gardiner" come to the conclusion that "there is probably no need to assume complete land connections across the Indian Ocean to explain the flora of its islands, or perhaps even the affinities of the African and Indian floras." We might even go a step further and say that there is no need of assuming the former existence of larger islands like those sketehed by Mr. Gardiner as occupying areas indicated by the two thousand fathom line. ${ }^{4}$

We made a fair ethological collection, the better part of which we owe to the kindness of His Highmess Muhammadu Imadudin, the Sultan of the Maldives. I have also to thank the Agents of the British India Steam Navigation Company at Colombo, Messrs. Bois Brothers and Company,

1 Loc. cit., Willis and Gardiner, 1. 162.

Loc. cit., ए. 140.

s Loc. cit., p. 123.

4 Loc. cit., Willis and Gardiner, PI. II. fig. 1. 
and Captain Fenwick for having carried out my instructions regarding the equipment of the "Amra." We found the steamer ready for us on our arrival at Colombo.

To the Riglt Honorable Joseph Chamberlain I am indebted for his kindness in giving me letters to the Government officials at Ceylon, and for writing to His Excellency Sir West Ridgeway in regard to our proposed visit. The Governor kindly wrote to the Sultan of the Maldives notifying him of the objects of our Expedition, and also gave us letters to the Snltan. His Highness took great interest in our work, gave us a circular letter to the chiefs of the various atolls, and in addition sent a representative and an interpreter to accompany us on our trip. Thanks to this, we were everywhere received with the greatest cordiality.

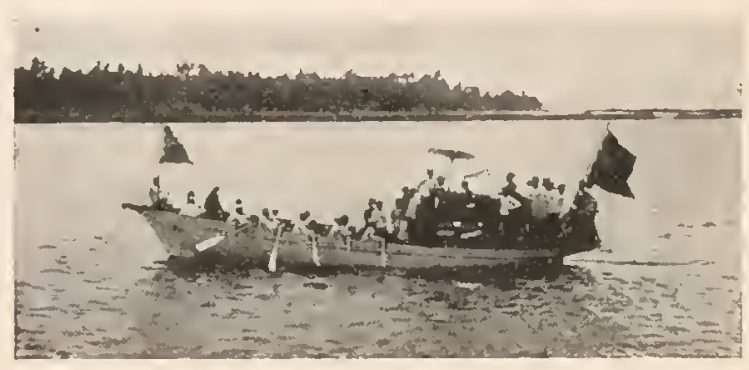

Tue Sultan's Barge

We started on our explorations from Male after having, on making the atoll, obtained a glimpse of the east coast of North Male as we skirted the atoll, from Mirufuri to Male Island itself. This stretch of coast together with the islands near Male and the actjoining faros ${ }^{1}$ of the lagoon to the northwest of Male contain all that is most cliaracteristic of the atolls of the Maldives. A glance at the Chart gave us an approximate idea of the problems to be solved in the study of the coral reefs of the group.

1 Faro is the name given by the natives to the small atolls which rise in the interior of the large lagoons or are found on their rims. It may be convenient to retain, as Mr. Gardiner has suggested, the Maldivian terms "faro" and "velu," * for the small atolls or ring-shaped reefs with their enclosed basin. Gardiner extends the term "velu" to the deep pools in the linear circumseribing reefs of many of the banks. This is likely to lead to confusion, as the mode of formation of the last is not necessarily the same as that of the velu proper.

We are also confronted with the difficnlty of distinguishing a faro from an atoll when the former constitutes a separate bank which may or may not be larger than a faro forming part of a land rim and larger than many an atoll in the Tropical Paeific.

* The Maldives and Laccadives Archipelagoes, I) I55. 
After examining North Male ${ }^{1}$ we passed to Ari, then to North and South Nilandu, crossing to Mulaku, making our way to Kolumadulu, to Hadduinmati, to Suvadiva, and to Addu, the southernmost atoll of the Maldives. On account of the heavy sea we were mable either on our way south or north to stop at Fua Mulaku, a small island between Suvadiva and Addu; but, judging from the chart and such accounts as I could obtain, it probably does not differ from similar islands in the Maldives.

Going north we modified our course so as to visit the faces of the atolls we had not seen on our way south, and to cross the lagoons from a different direction, taking thus a bird's eye-view of the atolls and islands. Our route was further daily modified according to the position of the sun to enable us to navigate the interior of an atoll in safety, or to take photographs as we passed, without loss of time.

On our way north we examined the atolls of the eastern chain which we had not seen: Wataru, Felidu, and South Male. From Male Island we exanined the westem parts of North Male which we had not visited before, passed on to Gaha Faro, to Karidu, to Fadiffolu, to Sonth Malosmadulu, to Goifurfehendu, to Middle and North Malosmadulu, to Miladummadulu, crossing to Makunudu and Tiladummati. We left the Maldives through one of the passages on the east face of Ihavandiffulu, the northernmost atoll of the group, after having steamed nearly sixteen hundred miles among the atolls of the Maldives.

Although the waters within the groups of atolls of the Maldives have been most carefully sounded by Commander Moresby and Lieutenant Powell, ${ }^{2}$ yet very little was known of the depths on the two sea faces of the great plateau upon which the atolls of the Maldives have developed, or of the depths in the chamnels separating them, until Mr. Gardiner's visit. $\mathrm{He}$ took a number of soundings across the central basin and a few of the channels separating the Central Maldives. ${ }^{3}$ The soundings of the Admiralty Charts give an excellent idea of the topography of the bottom of the lagoons of the composite atolls; their greatest depth is not much more than forty

1 Pl. 1 shows the track of the "Amra" through the Maldives.

2 B. A. Charts Nos. $66 a-c$.

3 The Fauna and Geography of the Maldive and Laccadive Arehipelagoes, edited by Mr. J. Stanley Gardiner, Vol. I., Part I., p. 19, and Introduetion to the above, pp. 10, 11 ; Part II., p. 150, Pl. X. 
fathoms. The depths indicate considerable variation over the bottom, and in some regions these changes in depth are very abrupt, from eight to over twenty fathoms in short distances. The character of the bottom varies greatly according to the locality and its vicinity to gaps, to passes, to islands or islets or sand-bars. In many cases the bottom is hard, swept clean by the currents, or covered with fragments coated with Nullipores, or it is covered with Corallines or made up of fragments of broken corals, or of coarse or fine coral sand. On one occasion the claspers brought up a piece of Millepore cut off from a living cluster from a depth of thirty-nine fathoms. This is an unusual depth for a reef builder, as in the Maldives the reef corals rarely extend below seventeen fathoms; twelve fathoms is the usual depth I have observed, there usually begin the sand lanes and patches which separate them, and finally end in covering the bottom.

We did not attempt to check any of the soundings on the Admiralty Charts. Within the atolls they exist in sufficient number for all theoretical and practical purposes, and for a party not sufficiently numerous and not properly equipped for the most delicate surveying operations it would have been hopeless to add any exact information to that already existing.

Our explorations were immensely facilitated from the existence of the admirable cliarts published by the Admiralty of the Survey of the Maldives by Commander Moresby and Lientenant Powell from 1834 to 1836 . The accuracy of these charts is something wonderful when we remember the conditions under which the surveys were made nearly seventy years ago, with sailing vessels and rowboats. In our extensive and intricate navigation among the Maldives we were guided absolutely by these charts and never found them in error. Of course some minor changes have occurred on the reef flats, such as the disappearance of an islet or of a bank, or the addition of a sand-bar and the junction of adjoining islands or islets on the same reef flats. Otherwise the charts stand to-day as they did seventy years ago, a monument to the insurpassed skill of the surveyors of those days. It was a simple task to pick out one's work in each atoll by an examination of the chart, and thus much time was saved. I have endeavored to adopt the spelling of the Admiralty Charts revised to May, 1903, but undoubtedly a few discrepancies will have occurred from our constant use of the older editions. 
In exploring any coral-reef region with a steamer a good deal of planning is necessary to enable one to see the interesting points of an atoll. 'The lagoon can be explored only with the sun in certain positions; one cannot steam east in the morning or west in the afternoon. 'To take photographs successfully the eastern face of an atoll must be explored in the morning and the western in the afternoon, that the sun may strike shallows and banks to define their limits and contrast their coloring with that of the deeper navigable waters of the atoll; and finally the programme must be so arranged as to reach an anchorage before sunset, and an anchorage so selected as to entail but little loss of time in leaving in the morning with the sun in a favorable position either for further exploration or to pass out of the channels of the atolls when the flats and banks flanking them are well defined and rendered plainly visible from the angle at which the sun shines upon them.

A mere glance at the Admiralty Charts of the Maldives ${ }^{1}$ cannot fail to show how very different in structure are Makunudu, Gaha Faro, Karidu, Goifurfehendu, Rasdu, Toddu, Wataru, Fua Mulaku, and Addu from such groups of atolls as North and South Male, Ari, North and South Nilandu, Felidu, the Malosmadulu atolls, Miladummadulu and its northern extension Tiladummati which might be ealled the Maldivian group of atolls par excellence. Both these groups may be contrasted again to such atolls or groups of atolls as Fadiffolu, Felidı, and Mulaku, which have as it were combinations or nodifications characteristic of the Maldivian atolls with features common to a number of Pacific atolls. And finally they may be compared to a third class of atolls like Kolumadulu, Haddummati, and Suvadiva, which remind us of the larger atolls of the Pacific in the Marshall, Ellice, Gilbert or Caroline Islands; atolls noted for the absence of shoals and of islands in the lagoons. The groups of small typical Maldivian atolls along the forty to thirty fathoun line of the great Maldivian plateau form an agglomeration of small atolls along that belt resembling the great land-rim reef flats of the Pacific atolls, but they have grown up as distinct parts and are separated by deep channels. These small atolls vary in size from a couple of hundred feet in diameter to atolls of seven miles in length. In

\footnotetext{
1 B. A. Charts Nos $66 a, b, c$.
} 
such clusters of atolls as those of North and South Male, of Ari, of Malosmadulu, and of other groups, their arrangement is such as to form welldefined rims, reminding us of the rims formed by great reef flats such as are common in the Pacific.

In such groups of atolls as Miladummadulu and its Tiladummati extension we liave the key to a rational explanation of the formation of the atolls and groups of atolls in the Maldives. The two atolls I have just named are not atolls in any sense of the word. They are so ill-defined that their division for political purposes is marked on the chart by a mere dotted line. In fact, they are composed of a great number of small atolls, often separated by considerable distances, as much as five to ten miles, which have gradually grown up on that part of the Maldivian platean from depths of twenty-five to thirty fathoms, and where they can be seen in all possible stages of growth.

The shape of the rings (faros) or bar's or flats is not necessarily circular; it varies greatly and is indirectly controlled by the topography of the bottom. Some of the faros are elliptical, pear-shaped, or crescent-shaped, differing greatly in ontline and dimensions on the onter lines of the composite atolls. Their outer slopes are covered with corals growing with great luxuriance from the edge or even from the surface of the flats of the ring to a depth of from eight to twelve or fifteen fathoms. The superb growth of corals found in all the lagoons of the Maldives is in marked contrast with the scanty growth of corals in the lagoons of the atolls of the Pacific. We have a simple explanation of this in the fact that the rim of the atolls in the Maldives is full of wide and deep passages. In fact, the extent of the passes is generally much larger than the space occupied by the small atolls (the atollons or faros) and reef flats.

As soon as the rim flats of the rings have reached the surface, either wholly or in part, sand-bars begin to form; these develop rapidly into islets, and finally into large islands more or less covered with scrub vegetation and bushes. The rings or faros either retain a central lagoon or it becomes partly or wholly filled up. In the former case they appear as small atolls with islands or islets on the reef flats; in the next stage there is either a smaller lagoon on the lee face of a larger island, or else the island has grown to occupy the whole flat of the faro with only very narrow flats on the 
lagoon faces of which corals grow. The larger islands are often covered with fine vegetation, large trees occupying the space bordered by the outer belt of bushes growing close to the beach. The greater number of the many islands which dot the large lagoons of the Maldives have been formed in the manner described, and it is comparatively easy to trace the progress of their development in all the stages intermediate between a mere ring, not yet rising to the surface, and a steep to island with its rich vegretation such as we find either in the lagoons or on the outer edge of a Maldivian composite atoll.

The small atolls which form the outer rim of the composite atolls owe their existence to the same causes, and their development can be as easily traced from a mere ring which has risen to the surface having more or less extensive flats on which islands or islets or sand-bars have been thrown up. The sea reef flats of the onter lines of atolls are usually wider than those of the lee face, and naturally so.

From my observations I am inclined to look upon Nullipores much as does Mr. Gardiner, ${ }^{1}$ as especially efficient in consolidating the corals and in the protection of reef platforms and flats. Nullipores also flourish on the sea faces of coral reefs to the greatest depths at which corals grow, but they are far more important below that depth in lagoons.

As far as I have examined the outer slopes of the reef flats or faros of the varions banks, they are covered with a growth of corals down to a depth of twenty to twenty-one fathoms, taking their greatest development at from five to nine or ten fathoms and rapidly disappearing from seventeen to twenty-five fathoms, where the coral slope passes into a region barren of reef corals.

Mr. Gardiner comes to the conchusion that about thirty fathoms is the extreme limit of the growth of the effective reef-building corals. He also noticed, what is generally the case in the Pacific, that, nodified by local conditions, corals grow more luxuriantly as the water becomes shallower to within three to six fathoms of the surface. From his obscrvations ${ }^{2}$ Gardiner concludes Darwin is correct in stating that the extreme depth of reef corals is not more than twenty-five fathoms. There are great diffi-

${ }_{1}^{1}$ Loc. cit., p. 177.

2 Loc. cit., n 325. 
culties in ascertaining the lateral rate of increase on the outer slope of a coral reef where it depends so largely upon local conditions within the bathymetrical range at which corals grow. There is great difference in the method of growth of corals on the reef flats or slopes of lagroons and of the exterior faces of coral reefs. The method of solidifying is quite different from the amount of sand on the flats within a lagoon, the excess of encrusting Nullipores on the sea faces, and the mass of coral fragments in constant movement on that face.

The rate of growth of branching corals is quite rapid, as is readily seen in the channels, cleared out every few years by the natives, leading through the outer recfs to the canals existing between them and the land. Mr. Gardiner has calculated from his observations that the coral reefs of Hulule might grow at the rate of a fathom in sixty years. ${ }^{1}$ On a bank of twenty-five to thirty fathoms depth ${ }^{2}$ patches of corals would grow over its surface wherever conditions were especially advantageous, and the outer patches might, according to the direction of the current, form a rim, such parts as were lower forming the passages through the encircling reef. This, according to him, would account for such atolls as Addu, Goifurfehendu, Gaha Faro, Makunudu, Wataru, Rasdu, as well as for atolls of greater size, like Felichu, Ihavandiffulu, Mulaku, and others of the central Maldives where the corals built up also sinall atolls on the rims; while on the great Tiladummati-Miladummadulu Bank the oceanic conditions prevailing have maintained the individuality of the separate faros.

Mr. Gardiner says no faro has reefs or shoals. This cannot be said of Rasdu, of the many faros of the northern part of Tiladummati, from Hanimadu to Kelai and to Gafuri; they are full of small shonls and banks and sand-bars. Gardiner is right in looking upon the condition of the shoals and reefs of the bank as greatly influenced by the extent of the circulation of the water. If the bank is represented by a small lagoon it is of course limited, but if by a great lagoon as Suvadiva, or a more or less open bank

1 Loc. cit., p. 332 .

2 It seems to me that the presence of such genera as Lophohelia on deep banks does not necessarily imply that thcy play so important a part in building up the deep coral banks of the Atlantic as to raise them from four hundred and thirty-five to fifty fathoms, the depth Mr. Gardiner assumes as the upper limit of growth of reef corals. 
as in Tiladummati and Miladummadulu, the circulation becomes almost oceanic. The reef and islands of portions of each bank will show the effect of the greater or more limited circulation. This is admirably shown by the condition of the reefs and heads described by Mr. Gardiner ${ }^{1}$ as existing in the "jungle of reefs" in North Malos.

Gardiner calls attention to the contrast of the slight growth of corals off a reef in an enclosed atoll or clusters like Haddummati or Kolumadulu to the luxuriant growth off a reef in open banks like Miladummadulu. This, in such large, comparatively open atolls, is often due quite as much to many minor local causes as to the prevailing oceanic conditions.

In the Maldives the increase in size of the islands on the outer land rim of atolls goes on much as we have observed it in the Gilbert, Ellice, Marshall, and Paumotu Islands. Small islets or islands on the same reef flats are gradually united by the formation of sand spits on the lee face of the islands, thus forming bays on the sea face of an atoll; the spits gradually approach, become connected, and the filling up of the bay from the sea face unites adjacent islands; their former discomnected state is merely indicated by a difference in the growth of the vegetation, a distinction which gradually disappears with years. The bay may also be formed on the lee sicle by the throwing up on the sea face of a bar on the edge of the reef flat between separate islands, and the bay may then be filled up both from the lee and weather side and thus unite separate islands or sand-bars.

The existence of lagoons completely shut off from the sea in some of the atolls of the northern part of the Maldives is readily explained by their mode of formation; this can be traced in all its stages, from the time the atoll consists of a crescent-shaped island occupying only a portion of the reef flat of the ring, the remainder of the reef flat of the ring still enclosing a comparatively deep lagoon sometimes with six to seven fathoms of water. The island throws out spits from the horns of the crescent until there is only a narrow pass left between them, and finally this gap is closed by a sand or shingle beach and we have the ideal atoll, - a closed ring of land enclosing a deep lagoon, which exists so rarely but is always the atoll to which one refers when discussing the coral-reef question. These phenomena are well

\footnotetext{
1 Loc. cit., p. 166.
} 
illustrated in the long line of crescent-shaped atolls occurring on the east side of Miladummadulu from Nalandu south as far as Bomasdu. Such a change, from an open crescentic island flanked by a lagoon to a closed land rim surrounding a lagoon, may take place with considerable rapidity. Bodu Mandu is represented on the chart as an open crescent-shaped island; we found it seventy years later a closed land ring completely surrounding a small lagoon with a depth of two fathoms.

The formation of fresh-water or brackish sinks edged with mangroves ${ }^{1}$ in some of the atolls can be traced to the same process which has formed enclosed lagoons. They occur on Kendikolu, Ekasdu, Nalandu, Madidu, and Filadu. The sinks differ from the lagoons only in being shallow, having been cut off by spits and bars extending across portions of the adjacent reef flats, covered only by water of a couple of feet or more in depth, while the enclosed lagoons were cut off from lagoons of atolls of considerable depth, six to seven fathoms or more.

What has been written above seems to me to point to the uselessness of our present definition of atolls. There is every possible gradation between a curved, crescent-shaped open bank of greater or less size and an absolutely closed ring of land surrounding a lagoon without direct communication with the sea. The evidence of a great number of atolls scattered on an extensive bank or plateau like that of Tiladummati and Miladummadulu shows that reef corals will grow upon any foundation where they find the proper depth, and that local conditions will determine their existence as fringing reefs, barrier reefs, or atolls. In fact, in the Maldives, reefs that once formed an atoll may in time, when the atoll or faro is changed into an island, become fringing reefs, $-\mathrm{a}$ transformation which is quite common both on the outer lines of islands and on islands in the interior of the larger basins.

The composite atolls of the Maldives have arisen upon minor elevations upon the greater Maldive plateau which have given to the reef-building corals a base at the proper depth from which they have risen to the surface. In such smaller plateaus as North Male, Ari, and others, there is found on the secondary plateaus in their turn a number of bases on which the atolls and faros have grown. In the central and most of the northern plateaus the con-

1 Messrs. Gardiner and Willis have called attention to the scarcity of mangroves on the Maldives. 
dition of exposure to oceanic currents is such that an immense body of water is constantly flowing across the plateau during both the northeast and the southwest monsoons. Where the plateans are smaller or not so open to the flow of eurrents as in such atolls as Addu, Karidu, Goifurfehendu, Gaha Faro, Wataru, Makunudu, and others, we have only a single atoll developed; again in such plateaus as those upon which Kolumadulu, Haddummati, and Suvadiva have developed, the conditions are oceanic, more similar to those we find in the widely separated atolls of the Ellice, Gilbert, or Marshall Islands. At the same time the lagoons of the southern atolls are far less open to oceanic circulation than those of the northern plateans, and thus we find fewer banks or islands in the lagoons, and only here and there a trace of those remarkable rings which are so characteristic a feature in Maldivian coral-reef scenery. I have seen nothing so striking in my experience of coral reefs as these rings with a light-colored rim standing out from the deep blue water surrounding them, like ghosts of an atoll which had sunk, and enclosing a lighter blue or emerald-colored lagoon indicative of its depth below the surface.

The conditions existing at the Maldives are repeated to a certain extent on the Yucatan Plateau, where the Alacran reef, a regular atoll, rises from it at a depth of about thirty fathoms. It is true that it is the only atoll on this extensive plateau; but there are also other irregularly shaped patches of coral reefs. The absence of atolls may be traced to the fact that the plateau is not within an area of such regular trades as are the northeast and southwest monsoons in the region of the Maldives. The central banks in the Tonga Archipeligo, the Haapai and Nomuka groups, with their irregularly shaped lagoon reefs and land-rim flats, remind us also somewhat of Maldivian conditions.

The moderate strength of the prevailing winds in the Maldives has greatly influenced many of the characteristic features of its atolls. The effect of the sonthwest and of the northeast monsoons cannot be compared to that of the trades in the Pacific. We have nothing in the Maldives corresponding to the incessant breakers of the huge rollers which pound upon the reef flats of the Paumotus and of the atolls and barrier reefs of the central and western Pacific. The boulders thrown upon the reef tlats are mere pyg- 
mies compared to the gigantic masses moved on some of the reef flats of the Pacific Islands. The boulder belts of the Maldives seem like a newly macadamized road as compared to the quarry blocks which often line miles of the beaches of some Pacific atolls. But the same forces are at work in the Maldives only on a diminutive scale, even during the prevalence of the southwest monsoon. The beaches both sand and shingle are as a whole lemarkably steep; they rarely rise to more than five or six feet, though in some of the northern atolls they are fully twelve feet high. Mr. Gardiner informs me he has seen dunes rising to twenty-eight or thirty feet in height.

The Maldives are remarkable for the small amount of coral breccia and conglomerate or beach rock which is rehandled. The material moved upon the reef flats is nearly all coral sand, - a great contrast to the Pacific atolls, where the wearing and crushing and rehandling of the reef rock ledges, both old and recent, are the most prominent features in the modification of the reef flats of the Gilbert, Ellice, Marshall, and Paumotu Islands.

There exist in the Maldives, it is true, a number of shingle beaches and boulder beaches on some of the islands exposed to the full action of the southwest monsoon both in the southern and northern part of the group; but these beaches are insignificant as compared with the wide reef flats and beaches of the Pacific atolls, which are strewn for miles with shingle and boulders often of a great size. This marked difference is due in the one case to the comparatively feeble sea and rollers of the southwest monsoon, in the other to the huge rollers of the southeast and northeast trades acting continuously with a force which bears no comparison to the forces at work in the Indian Ocean.

Mr. J. Stanley Gardiner spent over three months at Minikoi; he has given a detailed account of the atoll. ${ }^{1}$ According to him the sea is rapidly eneroaching upon the east face of the island. He looks upon the Minikoi conglomerate, found at the base of the onter beach, as a reef rock similar to the conglomerate I have observed at so many of the Pacific atolls ${ }^{2}$; showing that Minikoi, as well as the Pacific atolls, must at one time have been subject to a slight elevation (which he places at twenty-four feet). The

1 Loc. cit., p. 13.

2 A. Agassiz, Mem. M. C. Z., Vol. XXVIII., Pls. 8, 11, 12, 40, 63, 135, 136, 158, 163, 171. 
boulder zone, as he calls the belt of masses of conglomerate, is what remains of the elevated coral rock which has not been washed or dissolved away. It is far more prominent at Minikoi than in the Maldives, but it does not attain the importance it has in many of the Pacific atolls. Judging from what I have observed in the Pacific, Mr. Gardiner is justified in assuming the existence of a lagoon in Minikoi at the time of its elevation, and in considering the atoll to have been stationary for a considerable period of time on account of the broad reef flat round most of its circumference."

It is unfortunate that Mr. Gardiner should speak of a perfect atoll or of a perfect reef. He thus characterizes not only Minikoi, but also Kiltan, Chetlat, and Kavaratti among the Laccadives, and speaks of Cardamum as an atoll either in a late or an early stage. Judging from the charts and in analogy with the formation of Minikoi, he considers their present land configuration due to elevation and subsequent erosion, as has been shown to be the case for many Pacific atolls. We might indeed speak of Niau in the Paumotus as a perfect atoll where the rim is continuous, or of Pinaki or Maraki where we have only a small narrow boat passage opening through the otherwise continuous wooded rim of the atoll. These atolls represent a stage of growth which ultimately will end in the filling of the lagoon and leaving a central shallow sink or pool as the only trace of the former existence of a lagoon.

While it is impracticable to subdivide atolls representing areas more or less ciremseribed by belts of land and of reefs awash, or submerged, they vary from submerged banks throngh all the intermediate stages of banks with creseent-shaped rims with or withont islands to the so-called perfect atolls with reef flats and passages and land rims. It seems to me misleading to refer to Addu as differing from all the other banks of the Maldives and Laccadives in its more perfectly typical atoll form. Certainly Minikoi, Goifurfehendu, Rasdu, Gaha Faro, Wataru, Makunudu are as typical atolls as Addu.

Mr. Gardiner has given an account ${ }^{2}$ of the mode of formation of atolls which calls upon solution as the essential factor for deepening the lagoon of

1 Mr. Gardiner has given a number of sections of Minikoi on page 30, loc. cit., showing the width of the reef flats at different points of the atoll.

2 Loc. cit., pp. 180, 181. 
an atoll after it has "become fairly perfect," 1 though he recognizes "the outwash of mud as an important and direct subsidiary cause." 2 It has considerable bearing on the nature of the deposits on the outer face of an atoll. The amount of detritus washed out of a lagoon depends again in great measure on the position of an atoll. If sheltered or exposed to the sweep of the monsoons, the amount of silt will greatly vary with the depth of the lagoon, and will be nore or less detrimental to the growth of corals wherever they happen to grow, on the lagoon or sea face.

No one can cross one of the Fiji atolls of the Lau group ${ }^{3}$ without being struck with the evidence of the action of solution on the islands, islets, and flats within the lagoon. Such atolls as Fulanga, Ongea, the Yangasí cluster, the Argo reef, and others of the Lau group show this effect most plainly. Islands like Kambara, Vatu Leile, Mango, are on a large scale, pitted, honeycombed, and under-cut by the combined wearing and solvent action of the sea. But with our present knowledge it seems difficult to assign to each factor its proportionate value.

Wherever in the Maldives reef rock was examined I found it without exception of the most modern character, a few exposures as horses on the beaches and on the reef flats would seem to indicate a slight elevation of the Maldives. If the existing conditions at the Maldives have been brought about by subsidence, it is strange we should not find anywhere on this extensive plateau, from the northernmost atolls as far as Kolumadulu, some trace, some outlier or some central rocks indicating the nature of the rocks composing the underlying plateau forming the base upon which the innumerable atolls of the Maldives have been formed. The conditions are in many ways similar to those of the Lau Islands on the eastern platean of Fiji. There the elevation has been considerable (to a height of one thousand feet), and everywhere indications are found of the character and age of the underlying strata. A similar condition exists in the Paumotus, where some of the tertiary elevated reefs attain an elevation of about three humdred feet. At the Maldives there is, however, only evidence of a very slight elevation.

1 This does not seem to hold good for Minikoi and other Laccadive atolls with shallow lagoons.

2 Loc. cit., p. 334.

8 A. Agassiz, Bull. M. C. Z., Vol. XXXIII., pp. $43,88$. 
In addition to the information to be derived from the charts and from Mr. Gardiner's Memoir on the Maldives, he was kind enough on two occasions, after his return from the Maldives, where he preceded me, to give me valuable details regarding many interesting localities. I can only close by expressing my admiration for the amount of work Mr. Gardiner was able to accomplish with the facilities at his command, and for the pluck and energy displayed by him and his companion, Mr. Cooper, in meeting, in native boats, the winds and currents which impeded their progress at every point, to say nothing of the constant discomforts to which they were subjected during their stay in the Maldives.

I have especially to thank Admiral Sir J. W. Wharton for the interest be took in our expedition, and for allowing me access to those of the original charts of Moresby deposited in the London Hydrographic Office of tlie Admiralty.

Newport, Rhode Islaxd, July 15th, 1903.

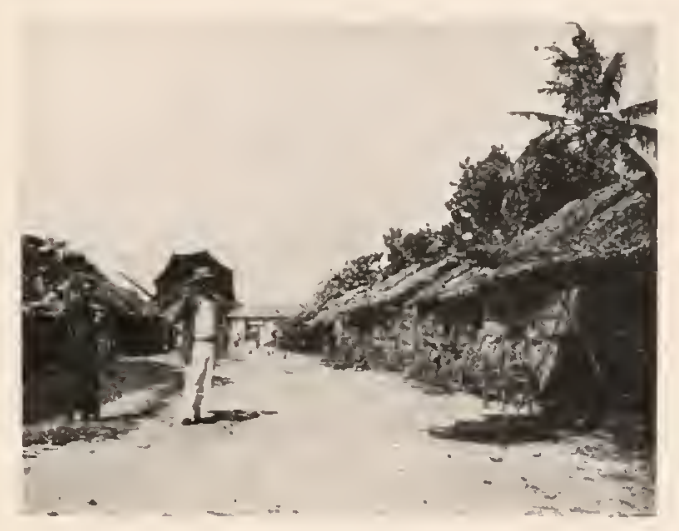

Strekt in Male. 







\title{
HYDROGRAPHY OF THE MALDIVES.
}

\author{
Plutes 1-8c.
}

IT was greatly to our advantage to have as a guide the surveys published by the Admiralty. ${ }^{1}$ We could obtain at a glance an accurate idea of the points of interest needing further examination and thus worked with great rapidity, losing no time in obtaining information by a tedious examination on shore of points of unknown value. This was specially important in a group of such simplicity and uniformity of structure as the Maldives.

It seems to me as if the conditions of portions of the Maldive plateau were very similar to those existing upon the Yucatan Platean inside the one-hundred-fathom line, where from a depth of about forty fathoms rise independent reefs such as the Triangles, Alacran Reef, the English, Opisbo, and Areas Banks.

There is however a great difference in the number of atolls found in the two regious. On the Maldivian platean in a distance of over four hundred and fifty miles there must be hundreds of atolls; while on the Yucatan plateau, three or four only of the patches can be designated as atolls in about the same length. The number of atolls and islands existing on the Maldives is estimated to be as great as ten thousand. This is probably an exaggeration. I have counted roughly the number of atolls and rings and islands of Ari and other groups. There are three hundred and ninety-one in the Ari

I The Maldives were surveyed during 1834-1836 by Commander Moreshy and Lieutenants Powell and Young. These surveys were published by the Admiralty as sheets $66 a, 66 b$, and $66 c$ (Pls. 1-6). The survey of Minikoi in 1891 by Commander Hoskyn is published as Admiralty Chart 2738; it also shows the relations of Minikoi to the Indian peninsula as well as to the Mallives and Laeeadives.

The Laceadives and the opposite coast of the Indian peninsula were surveyed in 1848 by offieers of the East Indian Government, and by officers of the Marine Survey of India in 1891-92; see Admiralty Chart 2.37 (Pl. 8).

II. O. Chart No. 1591 shows in a convenient form the ennnection of the Maldives and of Minikoi with the southern part of the Indian peninsula and with Ceylon (Pl. 7). From Admiralty Chart 748 B (Pl. 7) bas been construeted. 
group, eighty-two in North Nilandu, one hmudred and twenty-eight in South Nilandn; but in this enmmeration each lagoon reef as well as each reef flat was counted as a unit, and no account was taken of the many islands which sometimes occur on each flat. In groups like Ari, North Male, and North Nilandn, the increase in number could not be great. But in an atoll like Suvadiva and such groups as South Male, Soutl Nilandu, Mulaku, Kolumadulu, and Haddummati, where are often a great number of small islands forming a chain on the extensive reef flats, then the number of islands on the reef flats we have considered as units becomes very great.

The coral reefs of the Haapai and of the Nomuka groups, the central part of the Tonga Islands, is another region which nay be compared to the Maldives. Both the Tongan groups are independent banks separated by narrow and moderately deep channels from the banks to the north and south of them, and themselves separated by a channel of about five miles with depths varying from three hundred fathoms in the central part of the channel to three hundred and fifty and nearly five hundred at its eastern and western extremities.

The Haapai and Nomuka groups hold to each other much the same relation which North and South Malosmadulu have. The plateaus of these groups are well defined by the steep falling off near the one-hundred-fathon line; from their shallower parts rise secondary plateaus forming the coral reefs of Nomuka and Haapai. The circular or elongated lagoon reefs of the Haapai Platean are flanked on the east and south by linear or circular reefs, while the Nomuka reefs are flanked by linear reefs, only on a part of the east face of the Nomuka Plateau. ${ }^{1}$

The Maldive Islands (Pl. 7) are about four hundred miles west of Ceylon. They extend north and south for a distance of about four hundred and seventy miles; from $7^{\circ}$ north latitude to fifty miles south of the Equator. The central part of the archipelago (Pl. 1) consists of two chains of groups separated by a channel, varying in width from less than ten miles between Miladummadulu and North Malosmadulu to over twentyfive miles between Ari and South Male.

1 Admiralty Charts 2421, 3099, 3100, 474 ; A. Agassiz, Mem. M. C. Z. Vol. XXVIII., Pl. 175, 192-197, Pls. 214-218. 
The northern extremity of the Maldives ( $\mathrm{Pl} .1$ ) consists of a single line of groups, Ihavandiffulu and Tiladummati flanked on the west by an isolated atoll, Makunudu. Then follows the eastern chain of the central Maldive basin, composed of the southern part of Miladummadulu, Fadiffolu, Gaha Faro, North and South Male, Felidu, Wataru Reef, and Mnlaku, while the western chain of groups consists of Nortl, Middle, and Southern Malosmadulu, Goifurfehendu, Ari, and North and Sonth Nilandu. Then comes the single southern row of groups (Pl. 1), Kolumadulu, Haddunmati, Suvadiva, and Addu.

The depth of the channel between the eastern and western chains varies from five hundred and thirteen fathoms in the central part of the channel, between Miladummati and North Malosmadulu, to oue hundred and ninetyfour, the greatest depth between South Nilandu and Mulaku (Pl. 1). The depth of the central basin increases gradually as we go north. It is two hundred and seventeen fathoms between Ari and South Nale; its northern part is separated by a shallow shelf west of North Male from the deeper basin to the east of Goifurfehendu, between it and Gaha Faro, where the greatest depth is two hundred and fifty-eight fathoms, increasing to two hundred and sixty-six, between South Malosmadulu and Fadiffolu and to five hundred and thirteen fathoms between North Malosmadulu and Miladummaduln.

The depths of the channels separating the southern groups of the double chain north of Kolumadulu indicate that the sonthern part of the central plateau dips rapidly to the eastward (Pl. 1). The greatest depth of Kudahuvadu Channel between Mulaku and Kolumadulu is nearly six hundred and fifty fathoms, while it is only two hundred and fifty-one fathoms in the channel between South Nilandu and Kolumadulu.

The eastward dip of the central basin can be traced from Mulaku to Miladummadulu from the depths of the western channels which are somewhat shallower than those dividing the groups of the eastern face. On the western flank of the central basin the depth of the centre of the channel between South Nilandu and North Nilandu is 200 fathoms. On the eastern flank in the centre of Sonth and North Wataru channels we find 253 and 283 fathoms. The depth of Ariyaddu Channel is 231 fathoms, that of 
Fulidu Chamel, 374 fathoms. The greatest depth between Goifurfebend and South Malosmadulu is 302 fathoms, that of North Kardiva Channel, 372 fathoms. From South Malosmadulu the central basin dips from 236 to 519 fathoms, and between Fadiffolu and Miladummadulu the greatest depth is 769 fathoms.

The groups which constitute the western and eastern chains of the central Ilaldives (PI. 1) are elevations of considerable size; they form the rim of an inver basin. The channels between the groups both on the eastern and western faces of the basin correspond as far as we know very nearly in depth with those of the nearest part of the central basin.

Our soundings ( $\mathrm{Pl} .1$ ) indicate that Kolumadulu is on the sonthern extremity of that part of the plateau of the Maldives which extends unbroken from Ilsavandiffilu south to Kolumadulu, or rather of a plateau of which the mululations are nowhere separated by depths greater than three hundred fathous; although between Fadiffolu and Miladummadulu a tongue of deeper water projects to the westward a considerable distance towards North Malosmadulu.

Sonth of Kolumadulu the conditions are different; Haddummati, Suvadiva, and Addu occupy small plateaus separated by considerable depths and distinet from the larger one to the north. Haddummati, although less than twenty miles sonth of Kolumadulu, is divided from the northern plateau by a channel over eleven hundred fathoms in depth (Pl. 1). Suvadiva rises from depths of over eleven humdred fathoms in the One and half degree Chamel, fifty-five miles in width, which separates it from Haddummati; and finally the small plateau of Addu, forty-five miles south of Suvadiva, rises from depths of nearly thirteen hundred fathoms, indicated in the central part of the Equatorial Channel. 


\title{
TOPOGRAPHY OF THE INDIAN OCEAN WEST OF MALABAR.
}

\author{
Plates 7,8 .
}

Tee Adniralty Chart (Pl. 7) contains a sufficient number of somdings to throw very important light on the depths of the Indian Ocean between the Malabar coast and the region south, and the Laccadives and Maldives. The one-humdred-fathom line rums nearly parallel to the coast at a distance varying from twenty-five to sixty miles, and again parallel to this from twentyfive to thirty miles further west rums the one-thousand-fathom line.

The Laccadives (Pl. 8) rise from a plateau bounded by the one-thousandfathom line, separated on the eastern side from the continental shelf by a chamel of from ten to forty miles in width with a depth between ten and twelve hundred fatloms, the width of the channel and its depth gradually increasing as we go south; so that between Kalpeni and Kiltan the distance between the eastern edge of the Laccadives and the one-thousand-fathom continental line is fully seventy-five miles, and the depth separating it from the Indian coast more than thirteen hundred fathoms.

Within the one-thousand-fathom line surromding the Laccadives plateau, rise quite abruptly the smaller banks and plateaus upon which are the coral reefs of the group. The five-hundred-fathom line of the plateans and banks are within moderate distances of the outer edge of the reef flats. This is indicated by the charts for Cora Divh, Sesostris Bank, and Bassas de Pedro, as well as for Cherbaniani Reef, Byramgore, Chetlat, Bitra, Peremul Par, Kiltan, Cardamum, Piti Bank. and Agatti. The same is the case for the more southern Laccadives, Elicalpeni Bank, Androth, Karawatti, Suheli Par, and Kalpeni, whicli rise from the leeper parts of the channel, over one thonsand fathoms, separating the southern Laccadives from the Malabar continental shelf. It is interesting to note in the Laccadives the existence of extensive banks similar in outline to some of the Maldive Banks or Plateans, such as Cora Divh, Sesostris Bank, the Bassas de Pedro. and Piti Bank with 
its northern extension, Cardamum Bank, which equal in depth and nearly equal in size the largest plateaus of the Maldivian groups, for Bassas de Pedro is seventy miles in length, and the Piti Bank about forty. Three of the larger banks have no islands or lagoon reefs, the others culminate in coral reefs, having the structure of atolls; some of the sinall banks are no larger than many lagoon reefs or faros in the Maldives.

The soundings (Pl. 7 ) also indicate a narrow swale from fifteen to twenty miles wide, limited by the one-thousand-fathom line, as uniting Ihavandiffulu in the northern Maldives with Minikoi. A similar ridge has been sketched out by the Valdivia, south of Addu, towards Diego Garcia, a distance of nearly three hundred miles; but Addu and Diego Garcia are separated by a much deeper channel, of twenty-five hundred fathoms in depth (Pl. 7), fully as great a depth as the average of the Indian Ocean to the east and west of the supposed Addu ridge.

A long ridge bounded by the one-thousand-fathom line seems to unite Kalpeni with Suheli Par with a somewhat deeper channel between it and the Laccadives to the north, of a greatest depth of over twelve hundred fathoms; while a much broader and deeper channel separates this rise from Minikoi and the small banks inmediately to the north with a greatest depth of nearly thirteen hundred fathons.

The fifteen-hundred-fathom line of the great tongue of the ocean ( $\mathrm{Pl} .7$ ), between Ceylon and the Maldives, extends north as far as the ninth degree of north latitude, to the east of Minikoi and the Laceadives about lalfway between them. On the west of the Laceadives and Maldives the fifteenhundred-fathom line rums close to the western shore of the latter off Ari; it is not more than eight miles from the one-hundred-fathom line to the west of the Laccadives; it runs in a northerly direction thirty miles west of Agatti to west of Cora Divh.

1 Wissenshaftliche Ergebnisse d. Deutsehen Tiefsee Expedition auf d. Dampfer "Valdivia." Frster Band, Oceanographie . . . v. J)r. G. Schott, 1902, p. 117., Taf. III.

The soundings on which the existence of this ridge are based are so widely separated that it is not possible to deternine if the deep soundings of twenty-five hundred fatloms to the west of the line run by the "Valdivia" do not extend aeross it as a deep valley fully as deep as the oceanie depths, both to the east and west. It seems somewhat far-fetehed to speak, as does Dr. Sehott, of the Carolines, Marshall, and Gilbert Islands as eonnected by a plateau with a depth of four thousand metres; and to speak of coral island districts as generally eonnected by sueb plateaus. 
The plateau upon which the Laccadives rise is nearly two hundred miles in latitude and about ninety in longitude. The two-thousand-fathon line runs nearly parallel with and at a short distance from the fifteen-hundredfathom line, only it does not follow the tongue of the latter to the east of the Maldives. ${ }^{1}$

There are other isolated banks to the north of the Laccadives off the continental slope (Pl. 7). A bank of about twenty iniles in length, of a least deptl of one hundred and seventy-eight fathoms, lies in latitude $14^{\circ} 30^{\prime}$ north, longitude $73^{\circ}$ east, it is separated from the one-lnundred-fathom continental line by a deptlı of more than five hundred fathoms. Fartler to the north in latitude $16^{\circ} 30^{\prime}$ north, longitude $73^{\circ}$ enst, is Angria Bank, twentyfive miles in length and twelve in breadth; it is separated from the onehundred-fathom line by a channel, with depths varying from one hundred and seventy to over two hundred fathoms; see Admiralty Chart 2737.

On the same chart are plans of Chetlat and of Kiltan 1slands. They are small atolls, each with an island occupying the eastern reef flat, and a narrow reef flat on the western face of a shallow lagoon witls a couple of boat. passages leading throngh the westem reef. These islands are steep to on the eastern face, but on the western face shallow soundings extend towards the one-liundred-fathom line about a quarter of a mile.

Minikoi (A. C. 2738) ${ }^{2}$ is usually considered as one of the Laccadives, yet it is only sixty-nine miles from the northernmost of the Maldives, while it is one lumdred and eight from the southernmost of the Laccadives. This is quite an artificial subdivision, and it seems to me that Minikoi and the Laccadives in the north stand to the Maldives much in the same relation which Addu and Suvadiva do in the south.

The Laccadives are independent plateans within the one-thousand-fathom line. Kalpeni, the sonthern bank, is separated from Minikoi by a chamel with a depth of twelve humdred and forty-seven fathoms, while Minikoi is

1 The "Valdivia" took some soundings between Colombo and Suradiva, the greatest depth obtainet being 4754 metres. Schott, loc. cit., p. 96 .

${ }^{2}$ Mr. Gardiner* has taken Minikoi as a typical atoll to which he refers the structure of the Maldives; it appears from the chart and from Mr. Gardiner's description as quite similar to some of the characteristic atolls of the Pacific. Not only Minikoi but the Lacearlires as well as the southernmost Maldires do not possess the characteristics of the composite Maldive atolls; on the contrary, they greatly resemble characteristic Pacific atolls.

$$
\text { * Loc. cit., p. } 27 .
$$


separated from the northern Maldives by a channel with not over ten humdred and seventy-two fathoms, - depths not greater than those between Haddummati and Suvadiva, or Suvadiva and Addu. From what has been stated of the relation between Minikoi and the northern Maldives, it belongs geographically rather to them than to the Laccadives.

The atoll of Minikoi is somewhat triangular, about five miles long, of a greatest width of abont three miles. The eastern face of the atoll is flanked by a long narrow island; there is no other land on the onter reef flat except a small island (Small-pox Island) on the sonthern part of its west face. At the northern apex of the atoll, a passage with from ten to twelve feet of water leads into a lagoon with a greatest depth of seven fathoms. The westem and southern sides of the lagoon are flanked by a wide shallow reef flat full of coral heads in the southern part, with a few small shallow banks in the central part of the atoll. Minikoi rises quite abruptly from a depth of about one thousand fathoms.

The northern Maldives are within the limits of the northeast and southwest monsoons; at the Equatorial Channel, however, the prevailing winds from May to December are westerly and southerly winds; the northeast monsoon reaches the Equator and even beyond it during January, February, and March. Addu is in the region of the variable winds beyond the influence of the monsoons.

The southwest monsoon blows with greater strength than the northeast, and it is interesting to trace the modifications brought about by these opposite winds on the faces of the islands exposed to their action. One can trace on the west coasts the action of the sonthwest monsoon with its eastern lee, while during the northeast monsoons the eastern face becomes the windward face. The position of an island, lagoon reef, faro, or ring in the interior of a group also greatly modifies the action of either of the monsoons upon its shores, according to the range they may have, due to the trend of the island or of the group. Thus a great number of combinations are formed in position and in time, all having more or less influence upon a given area. They give us generally simple causes to account for the wasting of an island or for its increase, for the existence of coral sand or of shingle beaches, or for the presence of reaches or of belts of boulders, for 
the formation of bays by the shutting off of parts of the reef flats either on the windward or on the leeward side of an atoll, for the existence of horses of coral reef rock across certain beaches, and for the formation of coral reef rock patches, pitted and weather-worn, rising above the general level of the surromding reef flats, for the formation of sinks, for the throwing up of dams, or even for the formation of a gap in the rim of an atoll. 'To elimatic conditions, as affected by the position of islands and groups of islands, we also owe the degree of development of the flora of certain sections, or even its final destruction; in others these forces begin to act only when the lagoon reefs have risen to sufficient height for the outer rim to come under the influence of the action of the sea upon its submerged reef flat rims.

The soundings taken by the "Amra" do not bear out the statement of Mr. Gardiner that all the various banks of the Maldives (Pl. 7) and Laceadives (Pls. 7, S) appear to have been built on the same set of fomdations. ${ }^{1}$ Several of the Laccadive banks are separated by depths of more than one thousand fathoms, and the banks from Cora Divh to Cardamum are enclosed by the one-thousand-fathom line. Minikoi is similarly isolated, and the plateau of the fifteen-hundred-fathom line alone can be said to form the foundation of the Laceadives and Maldives (Pls. T, 8).

At any rate, the main chain of the Maldives does not lie alone upon a relatively shallow platean at a depth of about two hundred fathoms." Goifurfehendu is separated from South Malosmadulu by a chamel of more than three hundred fathoms, South Malosmadulu from Fadiffolu by over five hundred fathoms, North Malosmadulu from Miladummadulu by abont the same depth, Makunudu from Tiladummati by a channel of nearly eight hundred fathoms, Fadiffolu from Karidu by three hundred and seventy-two fathoms, and from Miladummadulu by seven hundred and sixty-nine fathoms, - depths greatly in excess of those separating the banks of the central Maldives from North Male to South Nilandu and Mulaku (Pl. 1). To the south, Mulaku is separated from the eastem face of Kolumadulu by a depth of nearly six bundred and fifty fathoms, and Kolumadulu from Haddummati by over eleven hundred fathoms, - depths nearly as great as those separating the banks of the southern Maldives (Pl. 1).

\footnotetext{
${ }^{1}$ Loc. cit., p. 172.

2 T.oc. cit., Pp. 150, 172.
} 
Gardiner has well shown that the topography of the central Maldivian basin almost precludes the idea that it was formed by the subsidence of a large central island. ${ }^{1}$ But it seems to me he is hardly correct in stating that the shallower water lies in the centre of the plateau and that the depth gradually increases in the passages. ${ }^{2}$ The deepest part of the central basin between South Male and Ari is in the centre; but as I have stated, there is a more marked dip of the central plateau to the eastward than to the westward, the eastern passages being deeper than the western ones.

That the precipitous slopes of the banks ficing the central basin indicate that they have been built up of corals or other organisms from a deeper plateau from a depth of over one hundred fathoms does not seem to me probable. ${ }^{3} \quad$ I should on the contrary consider each of these banks as an independent one as much as Makumudu, Goifurfebendu, Fadiffolu, Haddummati, and the southern banks. The existence of such banks as North Malosnuadulu and Kolumadulu, - the former rising from a depth of about two hundred fathoms at its southern, of nearly five humdred at its northern extremity, and from over twelve hundred fathoms on the western side; the latter rising on the northwest from a depth of over two huudred and fifty fatlioms, on the northeast from over six humdred, and on the southeast from over eleven hundred fathoms, - can only be explained on the supposition that they are independent banks. The existence of a deeper central valley between North Malosmadulu and Miladummadulu, off Fadiffolu and Kolomadulu, developed by the soundings of the "Amra," shows a far greater irregularity in the deptis of the plitean than is assumed by $\mathrm{Mr}$. Gardiner, ${ }^{4}$ and maturally modifies to a considerable extent the conclusions he draws from the existence of such a great level central plateau. ${ }^{5}$

According to Darwin ${ }^{6}$ there has been a disseverment of large atolls into smaller ones in the Maldives, but that "this process can be observed only in the northern half of the group, where the atolls have imperfect margins consisting of detached basin-formed reefs." He imagines the strong currents

1 Loc. cit., p. 122.

${ }^{3}$ Iarwin * calls attention to the steepness of the slope off the Maldives in spite of the sandy nature of the bottom of the slopes, slopes which excecd fifty-five degrees.

${ }^{4}$ Loc. cit., p. $174 . \quad{ }^{5}$ Loc. cit., p. $175 . \quad{ }^{6}$ Coral lieefs, p. 143.

* Coral Reefs, p. 31 . 
which flow across these atolls to have broken "through the many wide breaches in their margin," and to have removed the finer sediment and deepened the channels. Such channels as divide Middle Malosmadulı from North and South Malosmadulu and the separate parts would then form distinet atolls like those of Ari and Ross, or the two Nilandus. "Further subsidence would render these channels unfathomable, and the dissevered portions would then resemble Felidu, Mulaku, and Horsburgh, which are related only in proximity."

From what the soundings made by the "Amra" teach, the ingenious suggestions of Darwin regarding the formation of the Maldives are not borne out. Nor does it seem possible, as he suggests, that the Maldive Archipelago originally existed as a barrier reef of nearly the same dimensions as that of New Caledonia. The central basin which separates the eastern and western Maldives has no analogue in New Caledonia, and even if the whole island were to subside, the section across the centre would in no way resemble that of the great Maldivian basin with its fringe of independent atoll-like groups. 


\section{ANALISIS OF THE SOUNDINGS TAKEN BY THE "AMRA." \\ Plutes 1-Se.}

A sounding (No. 76) ${ }^{1}$ taken in the centre of Gallandn Channel between 'Tiladummati and Ihavandiffulu (PI. Sa, fig. 3) gave a deptl of two hundred and fifty-one fathoms with a bottom of coarse coral sand.

On the Admiralty Chart ${ }^{2}$ are a number of somdings off Jhavandiffulu, rumning into ten hundred and seventy-five fathoms, at a distance of eleven miles to the westward, normal to the trend of the west face (Pl. $S a$, fig. 1). The onter edge of the slope must be quite flat, as nine hundred and ninetytwo fathoms was obtained five miles from the face of the atoll. The soundings within a distance of five miles off the northern, the northeastern, and sontheastern faces indicate a slope similar to that off the western face. The sounding of seven humdred and eighty-one fathoms, seven miles to the east of Kelai, even indicates a somewhat flatter slope (Pl. $8 a$, fig. 2), off the northeast horn of Tiladummati. From this a tongue of deep water rums westward towards the ridge connecting Tiladummati with Ihavandiffulu (Pl. 2).

The other lines we sounded to ascertain the slope of the oceanic faces of the Maldives are off North Male (Pl. Sc, fig. 24), off the west face of North Malosmaduln (Pl. Sc, fig. 26), off the west face of Ari (Pl. Sc, fig. 25), off the east face of South Malc (PI. 8c, fig. 27), and off Addu (Pl. Sc, fig. 21), in addition to the lines between the sonthern Maldives (Pl. Sc, figs. 22, 23).

Line across the chamnel between Miladummadulu and the northern extremity of Makmundu (Pl. 8 a, fig. 7).

Makunudu is separated from Miladummadulu by a channel with an oceanic bottom of a greatest depth of nearly eight hundred fathoms; it rises from a small secondary platean on the western slope of the northern

1 The numbers refer to the List of Soundings, p. 29.

2 Aimiralty Chart, $66 a$. 
part of the Maldives. One mile west of the northern extremity of the faro, southwest of Goadu Island, we sounded in five hundred and four fathoms with a bottom of fine greenish sand with Globigerinae (No. 73). Four miles from the same starting-point in the centre of the chanmel, we obtained seven hundred and ninety-two fathoms (No.74) with a bottom of broken shells. One mile east from Makunudu we sounded in five hundred and sixty-six fathoms with a bottom of coarse coral fragments (No. 75). Its western face must be steep and cannot be far from the fifteen-hundred-fathom line.

The soundings between Miladummadulu and North Malosmadulu (Pl. Sa, fig. 5) seem to indicate that a tongue of deep water extends northward from the centre of the ehannel between Fadiffolu and Miladummadulu (Pl. 3) towards the northern part of the central basin, and also southward towards the western point of Fadiffolu.

We ran three lines of soundings across the northern part of the central basin of the Maldives.

A northern line across its narrowest part between Mavila (Milarlummadulu) and Furidu (North Malosmadulu) (Pl. 8 a, fig. 5).

One mile west of Mavila, we sounded in four hundred and twelve fathoms (No. 70) with a bottom consisting of green coral sand mixed with broken shells and Pteropods. Fom and a half miles from the same point in the centre of the ehamnel, we obtained five hundred and thirteen fathoms (No. 71) with a bottom of fine eoral sand and Globigerina ooze. One mile east of Furidu, we obtained two hundred and eighty-six fathoms (No. 72) with fine coral sand and Globigerinae. The soundings we took of the west coast of North Malosmadulu (Pl. Sc, fig. 26) indicate a less steep slope than further south, off the western part of the platean. We obtained off Ari (Pl. Sc, fig. 25), at a distance of seven miles, a depth of nearly fifteen hundred fathoms (No. 9); while off the coast of North Malosmadulu we sounded in twelve hundred and forty-seven fathoms (No. 65), at a distance of eight miles.

A second line across the northern basin ran from Kanifuri (Fadiffolu) to Mabaru (South Malosmadulu) (Il. Sc, fig. 2S). 
One and a half miles west of Kanifuri we found five hundred and nineteen fathoms (No. 5T), with a bottom of sticky yellow coral ooze, with but few Globigerinae and little sand and Pteropod shells. Five and a quarter miles from the starting-point in the centre of the chamnel, we sounded in three humdred and sixty-six fathoms (No. 58), with a bottom of green, fine coral ooze, with few Globigerinae. A mile and a half from Mabaru Island the depth had decreased to two hundred and thirty-six fathoms (No. 59), with a bottom of broken shells and coral sand.

The plateau evidently dips rapidly to the eastward from the centre of the channel.

Our third line across the northern central basin ran to the west of Gahi Faro towards Coifurfehendu; the soundings of the other extremity of the line from Goifurfehendu east were taken while rumning to Goifurfehendu after leaving South Malosmadulu (Pl. 8 a, fig. 8).

One and a half miles to the west of the western entrance to Gaha Faro, we sounded in one hundred and forty-nine fathoms (No.49), with a bottom consisting of coral sand and masses of large Globigerinae. ${ }^{1}$ Nine miles from our starting-point, we obtained two hundred and fifty-eight fathoms (No. 50). In continuation of this line we obtained, seven miles east of Goifurfehendu, a depth of two hundred and thirty-seven fathoms (No. 60), with a bottom of fine green sand and masses of Globigerinae or Globigerinae sand. One and a half miles east of Goifurfehendu, we found two hundred and twelve fathoms (No. 61), with fine green sand and Globigerinae sand, showing a comparatively shallow plateau extending to the west of Gaha Faro towards Goifurfehendu, though it deepens somewhat to the west of Goifurfehendu, as is shown by the line from Goifurfehendu to South Malosmadulu, which has a greatest depth of three hundred and two fathoms in the centre of the channel separating them. The platean again deepens to the northward, as is shown by the deptlı obtained between Gaha Faro and Fadiffolu, which varies between two hundred and forty-one and three hundred and seventytwo fathoms (Nos. 51, 56).

1 In the channels open to the sea, Globigerinae often occur in such quantities that we might with advantage eall that kind of bottom Globigerina sand. 
Line off the west coast of the sonthern part of North Malosmadulu (Pl. $8 e$, fig. 26).

Eight miles off the coast in a northwesterly direction from Femfuri Faro we sounded in twelve lunndred and forty-seven fathoms (No. 65). One mile off Maregiri, we obtained three hundred and seventy-eiglit fathoms (No. 66), and already found a bottom consisting of green coral sand mixed with Pteropod shells and Globigerinae. Pteropod shells are common in shallow somdings near the atolls; we collected them in number, as well as Globigerinae, in nearly all our surface tows made off the outer faces of the archipelago.

We did not sound any of the Malosmadulu Channels (Pl. Sb; figs. 9, 10), the soundings on the Admiralty Charts being sufficiently numerous to define their depth.

According to the Admiralty Chart (No. $66 a$ ), Sonth Malosmadulu is separated from Middle Malosmadulu by a chamel from two to three miles wide, with sonndings in the axis of the chamnel langing from one hundred and ten to one hundred and forty fathoms. Middle Malosmadulu is separated from North Malosmadulu by Moresby Chamel, somewhat wider than the chamnel to the south of it, about three miles in width, with soundings in the centre of the channel ranging from one hundred and twenty to one hundred and thirty-five fathoms.

Line across the chamel between Furudu (Goifurfehendu) and Maduwari (South M:tlosmaduln) (Pl. Sb, fig. 10).

One mile north of our Goifurfehendu base-line we obtained two hundred and forty-eight fathoms (No.62), with a bottom of coarse coral sand and broken shells. In the centre of the chamel, three and one-half miles from the starting-point, we sounded in three hundred and two fathoms (No. 63); bottom of coral sand and broken shells. One mile from Maduwari we sounded in one hundred and ninety-three fathoms (No. 64), bringing up in the claspers a few fragments of broken corals. The bottom of this channel is apparently covered with coarse coral sand, broken shells, and corals. 
Line across the channel between Fadiffolu and Miladummadulu (Pl. $8 a$, fig. 4). From Hurawali (Fadiffolu) to Karema (Miladummadulu).

One mile north of Hurawali we found three hundred and forty-two fathoms (No. 67), hard bottom. Four miles north, in the centre of the channel, we obtained seven hundred and sixty-nine fathoms (No. 6s). One mile south of Karema we sounded in three hundred and forty fathoms (No. 69). Unfortmately, no sample of the bottom of this ehamel was obtained. No. 67 indicated a hard current-swept bottom.

Line across Kardiva Channe], from Gaha Faro to Aligau (Fadiffolu) (Pl. $8 b$, fig. 11).

One and a half miles north of Gaha Faro we sounded in two hundred and forty-one fathoms (No.51), and brought up a fragment of Oculina. Six miles morth of Gaha Faro, halfway to Karidu Island, we obtained two hundred and fifty-eight fathoms (No. 52), with a hard bottom; and a mile and a half south of Karidu we got two hundred and ninety-eight fathoms (No. 53), bringing up coral sand and small fragments of Pteropod shells. One mile north of Karidu we found three hundred and twelve fathoms (No. 54), and brought up small pieces of pumice from a hard bottom. In the centre of the channel between Karidu and Fadiffolu, seven and a half miles north of Karidu Island, there seems to be a distinct ridge, as we only obtained one hundred and ninety-seven fathoms (No.55), with a bottom of clean coarse Globigerinae sand. One and onc-half miles south of Aligau (Fadiffolu), we sounded in three hundred and seventy-two fathoms (No. 56), with a bottom consisting of coarse coral sand and Globigerinae sand. The edge of the Maldivian plateau drops gradually to the north of Gaha Faro from two hundred and forty-one to three hundred and seventytwo (Nos. 51, 56) near Fadiffolu.

The northern part of the central basin is very open to the sea (Pl. 1); between Gaha Faro and Fadiffolu it slopes to the east, only a few higher knolls, like Karidu, and the sounding of one hundred and ninety-seven fathoms (No. 55) to the north, indicating its boundary. 
Line from North Male to Gaha Faro (Pl. $8 a$, fig. 6).

In the centre of the channel, between Gaha Faro and North Male, we obtained a depth of one hundred fathoms (No. 48). The claspers only bronght up a fragment of pumice, covered with Bryozoa, Algae, and Nullipores.

Mr. Gardiner states that pumice was found on all beaches of the Maldives, and that it was not known before the eruption of Krakatoa in 1883 . But pumice must have found its way on the beaches of the Maldives earlier, as it occurs inland on many of the islands.

The bottom of all the cliannels separating the composite atolls of the central Maldives appears to be quite flat, the somndings off shore drop rapidly; generally at a distance of a mile and a balf from either face they attain a depth but little inferior to the greatest depths in the centre of the chamnels.

Line of soundings west of North Male (Pl. Sc. fig. 24).

One mile due west, off the normal to the pass west of Hembadn, in the centre of the western face of North Male, we obtained one hundred and twenty fathoms, with coral sand (PI. 1). At a distance of three and one-half miles the depth only increased to one hundred and fifty-nine fathoms with a bottom of sticky coral sand, and at seven and one-half miles we ran only into one hundred and eighty-six fathoms, with a bottom of fine green sand filled with Globigerinae.

Judging from this line of soundings and from the soundings existing ${ }^{1}$ between the northern part of Ari and Rasdu and Toddu, as well as to the westward of these atolls, these atolls are on the western edge of a shallow plateau extending west of North Male and north to Goifurfehendu. This plateau separates the northern part of the central basin from the southern; it drops off very rapidly to the westward of Ari, if we may judge from the line of somdings we ran to the west of the pass south of Mandu (Ari) (PI. $8 c$, fig. 25). At a distance of three miles off the normal we ran into nine hmindred and eight fathoms (No. S), and eight miles off Mandu Pass we obtained fourteen bundred and ninety-eight fathoms (No. 9). The bottom 
in the first sounding was composed of light-green fine coral sand with numerous Globigerinae. In fourteen hundred and ninety-eight fathoms we found bluish ooze with a greater number of Globigerinae.

Line of soundings across Wadu Channel (Pl. 8 b, fig. 19).

We ran a line normal to the pass between Male and Toddy Islands (North Male), to Wadu Island (South Male). One mile sonthwest of Mate Island we found two hundred and sixty-five fathoms (No. 1); hard bottom. In the centre of the channel the depth was somewhat less: two hundred and fifty-nine fathoms (No. 2), hard bottom, and one mile from Wadu two hundred and thirty-nine fathoms (No. 3), with broken corals and shells. The deepest part of the chamnel is near North Male, the bottom of the channel rising slightly towards Sonth Male. The flat plateau of Wadu channel extends well to the eastward, as we obtained three hundred and nineteen fathoms (No.47) nearly five miles to the eastward, about two and one-half miles northeast off the outer reef flat of Huras, South Male.

The somnding of one thousand and five fathoms two and one half miles from Hulule Island, given by Mr. Gardiner, ${ }^{1}$ indicates either a sharp bight to the westward in the one-thousand-fathom line, or that Mr. Gardiner may have used too light a weight (fifteen pounds) to rum ont his line. We found the one-thousand-fathom line (No. 45) at least six miles off the central part of the east face of South Male, and in our own soundings a sixty pound shot none too heavy for the deeper somdings in passes where the currents often ran with great violenee.

Everywhere in the Maldives the strong currents appear to extend to the bottom of the channels separating the banks; they sweep the bottom clean, and must, as has been observed by Mr. Gatrdiner, exert considerable influence in keeping them clear, and may also have greatly contributed to their origin.

Line rumning east of Sonth Male, from Guru Pass (Pl. $8 c$, fig. 27).

Three miles due east of Guru Pass we sounded in nine lundred and sixty

1 Mr. Gardner's* sounding lies between our soundings of two hundred and fifty-nine (No. 2) and three hundred and nineteen fathoms (No.47) off the southeast corner of Male.

* Loc. cit., p. 153. 
fathoms (No. 44), with a bottom of fine greenish coral sand with many Pteropod shells and masses of Globigerinae. Eight miles from our startingpoint, we obtained twelve hundred and thirty-eight fathoms (No.45), with a bottom of fine grayish ooze containing mineral particles and many Globigerinae. Twelve miles east of South Male, in continuation of the same line, the depth has only increased to twelve hundred and seventy fathoms (No. 46), with a bottom of fine gray Globigerinae ooze. We also sounded one mile normal to the northeast horn of South Male, and obtained a depth of three hundred and nineteen fathoms (No. 47), hard bottom. The only other soundings off the east slope of the Inaldive platean are those off the northern horn of 'Tiladummati and off Ihavandiffulu in Admiralty Chart, 66a, and the soundings taken by the "Amra" on the way to Colombo from Ihavandiffulu (Nos. Tテ-79).

We ran two lines of soundings across the southern part of the central basin of the Maldives, the one partly to the north, the other to the south of the lines rum across this basin by Mr. Gardiner." His soundings of the central basin agree well with those of the "Amra." 2

Northern line of soundings from Waregili (west face of South Male) to the east face of Ari (Kadibudu) (Pl. 8 b, fig. 12).

Across the basin separating the eastern from the western chain of groups we obtained, two miles off the west face of South Male, a depth of one hundred and eighty fathoms (No.4) with fine greenish coral sand, many Globigerinae, and a few Pteropods. Eight miles further west we found the same bottom in a depth of two hundred and eiglit fathoms (No. 5). Sixteen miles further, a point at about the same distance east of Ari, the depth was two hundred and seventeen fathoms (No. 6), and three miles off the east face of Ari it had diminished to one hundred and seventy-seven fathoms (No. T).

These soundings show a very flat basin dropping rapidly on both" sides, within a short distance of the edges of the channel, to nearly the depth of the central part of the channel, with a bottom of an oceanic character: Globigerinae mixed with Pteropods.

$$
1 \text { Loc. cit., p. 4, fig. 2. } \quad{ }^{2} \text { Loc. cit., p. 152, Pl X. }
$$


Sonthern line across the central basin ran from Konipafuri (Sonth Nilandu) towards Kureli (Mulaku) (Pl. 8b, fig. 13).

Two and a half miles off Konipafuri we obtained one hundred and sixtyone fathoms (No. 13) with a bottom of fine coral sand mixed with Pteropod shells and green Globigerinae. At a distance of seven and one-half miles from our starting-point we sounded in one hundred and eighty-one fathoms (No. 14), the bottom consisting of fine green coral sand with many Globigerinae and shells of Spirialis and many other Pteropods. Twelve and one-half miles from the starting-point we obtained one hundred and ninety-four fathoms (No. 15) with very fine green coral sand mixed with Globigerinae shells of Spirialis and other Pteropods; and about four miles north of Kureli we fonnd a similar bottom in two hundred and five fathoms (No. 16).

This channel shows, after the first abrupt drop off shore, the same general flat bottom as aeross the northern part between South Male and Ari, but with a slight increase in depth as we go east from South Nilandu to Mulaku. The bottom of the southern part of the central basin is like the northern part oceanic in character, composed of Globigerinae mixed with Pteropods.

To determine the western slope of the eentras part of the Maldive plateau we ran a line from Mandu Pass, west of Ari, into nearly fifteen hundred fathoms (Pl. $8 c$, fig. 25). Three miles off the normal to Mandu Pass we sounded in nine hundred and eight fathoms (No. 8); fine lightgreen coral sand bottom and Globigerinae. Eight miles off the startingpoint we obtained a sounding of fourteen hundred and ninety-eight fathoms (No. 9); with a bottom of light bluish-gray fine coral sand and ooze, with many Globigerinae. This part of the Maldivian plateau falls off quite rapidly to the westward, more so than the northern part of the western slope (see Nos. 65, 66; 73-75, and Admiralty Chart, $66 a$ ).

Line across Fulidu Channel, from Fulidu Pass, east of Fulidu Island, towards Hutekolu (South Male) (Pl. 8b, fig. 16).

One mile north of Fulidu Pass, east of Fulidu Island, we obtained two 
hundred and seventy-six fathoms (No. 41), with a bottom consisting of fine corill sand, Pteropod shells, and masses of greenish Globigerinae. Four miles from the starting-point, halfway across the channel, we sounded in three hundred and seventy-four fathoms (No. 42), bringing up in the eup fragments of white corals, coated with manganese. One and one-half miles south of South Male Atoll (Hutekolu), we obtained two hundred and fortythree fathoms (No. 43), bringing up in the cup small fragments of coral.

The nature of the bottom of the main channels between the composite atolls of the east or west chain varies greatly, some of them having, like Wadu, Eastern Kudahuvadu, Fadiffolu to Miladummadulu channels, a hard bottom swept clear; in others the botton is composed of Globigerinae and Pteropods, as in Fulidu and Kardiva channels, and others of coral sand and broken shells, as Ariyaddn, Wataru, and Gallandu, or coral sand and Globigerinae, as in Veimandu, West Kudahtivadu, Gaha Faro to Goifurfehendu.

Line of somndings from Mulaku to Wataru Reef and to Felidu (Pl. \&b, fig. 15).

Halfway between Mulaku and Wataru Reef, in the centre of the channel, we found a depth of two hundred and fifty-three fathoms (No. 39). The northern channel separating Wataru Reef from Felidu is somewhat deeper than the southern one; we obtained two hundred and eightythree fathoms (No. 40) in the centre of the channel, halfway from Wataru Reef to Felidu Atoll, the bottom consisting of broken corals, shells, and of coarse coral sand.

Line of soumdings across Ariyaddu Channel from Ariadu (Ari) to the nearest point (clump of trees) in the northern face of North Nilandu (Pl. 8b, fig. 14).

One mile from Ariadu Pass we sounded in one hundred and forty-nine fathoms (No. 10). In the centre of the channel we obtained two hundred and thirty-one fathoms (No. 11), the bottom consisting of fragments of corals and of coral sand and broken shells. One mile from North Nilandu we sounded in one hundred and seventy-seven fathoms (No. 12), with a coarse coral sand bottom, Ariyaddu Chamnel showing the same flat bottom 
characteristic of other channels separating the groups of the two sides of the central basin of the Maldives. The bottom of this channel seems to be composed wholly of coral sand and broken shells.

A sounding of two hundred fathoms being marked in the Admiralty Chart $(66 b)$ in the centre of the channel between North and South Nilandr, and indicating the same general depth found in other channels, we did not think it necessary to make any other soundings while running across to South Nilandu from Magndu.

Mr. Gardiner somded this channel and obtained a greatest depth of two hundred and thirty-five fathoms in the centre of the channel. ${ }^{1}$

Line of sonndings betweẹn Mulakn and Kolumaduln across the Kudahuvadu Channel from Mulaku to Wilifuri (PI. S6, fig. 18).

Four miles south of Mulaku we obtained four hundred and three fathoms (No. 17), with a hard rocky bottom. Nine miles from our startingpoint in the centre of the channel. we ran into six hundred and forty-nine fathoms (No. 1S), with a fine gray ooze. Two miles from Wilifuri, we sounded in two hundred and eighty-two fathoms (No. 19), a deptl considerably greater than we found at the same distance off the west face of Mulaku.

The eastern opening of Kudahuvadu Channel is deeper than the corre. sponding western chamel separating South Nilandu from Kolumadulu. The southern extremity of the central basin of the Maldive platean dips rapidly towards the east, judgring from the soundings across Kudahuradu (Nos. 17 19, 36-3S) and Veimandu (Nos. 20-23) channels.

Line of somdings across Kudahuvadu Channel, between Kandufuri (Kolumadulu) and Maimbudu (South Nilandu) (Pl. Sb, fig. 17).

We obtained one and a half miles off Kandufuri two hundred and fiftythree fathoms (No.36), with a bottom of coarse coral sand mixed with broken Pteropod shells. Halfway across the channel, six and a half miles from our starting-point, we sounded in two hundred and fifty-one fathoms 
(No. 37), with the same sort of bottom as nearer Kolumadulu. Within a mile and a half from Maimbudu (South Nilandu), we obtained two hundred and two fathoms (No. 38), with a bottom of fine greenish coral sand mixed with many Globigerinae.

The bottom of the western Kudahuvadu Channel is oceanic in character, not only in the centre, but also quite close to South Nilandu, Mulaku, and Kolumadulu; while the bottom of eastern Kudahuvadu Channel (Nos. 17, $19)$ is hard and swept clean by currents.

Line across the Veimandu Channel from Timarafuri Pass (Kolumadulu) to Munafuri (Haddummati) (Pl. $8 c$, fig. 20).

Two and a half miles off Timarafuri we were already in seven hundred and thirty-eight fathoms (No. 20), with a bottom of coarse coral sand and broken shells. Seven miles off the starting-point in the centre of the channel, the depth had increased to eleven hundred and eighteen fathoms (No. 21); the bottom was still made up of coarse coral sand, though somewhat finer than that of the previous sounding. Two miles west of Waduni Pass we obtained eight hundred and forty-three fathoms (No. 22). Three quarters miles off Haddummati, we sounded in eight hundred and ninetyseven fathoms (No. 23), with a bottom of a mixture of coarse and fine coral sand with many Globigerinae.

Kolumadulu forms a bar across the southern extremity of the central basin of the Maldives, on the two sides of which to the north are arranged the great Maldive atolls, while to the south, including Kolumadulu, the Naldives form only a single line of atolls.

These soundings are interesting as showing the very sudden drop in depth off the plateaus on the two faces of the Veimandu Channel. They also illustrate the gradual increase in depth of the channels separating the single groups as we go south, and the greater isolation of these plateaus as compared to the shallower channels which separate the higher plateaus of the northern and of the parallel chains of groups of the Maldives.

The depth of the centre of Veimandu Channel is as great as that in the channel separating the northern Maldives from Minikoi (Pl. 7 ), though in one case the channel is only sixteen miles wide, while in the other the 
distance is fully seventy miles, and its greatest depth ten hundred and fifty-seven fathoms. Still further north, the Laccadive group, small isolated summits, with comparatively small atolls, resemble in every respect the smaller and widely separated atolls of the Ellice and Gilbert groups, a series of independent summits separated by at least two thousand fathouns of water and scattered over a distance of fifteen degrees of latitude. The distance from Minikoi to the most distant Laceadive bank is not more than four hundred and twenty miles, with deptlss of little over one thousand fathoms.

Line from Haddummati to Suvadiva (the One and half degree Channel) (Pl. $8 c$, fig. 22).

Our starting-point was halfway across the normal between the reef flats off Gadu and Hitadu; four miles south we obtained nine hundred and eighty-seven fathoms (No. 24), with a bottom composed of fine coral sand, broken shells, and Globigerinae. Fourteen miles south of Haddummati, in ten hundred and seventy-eight fathoms (No. 25), we brought up small, flit, irregularly shaped manganese nodules, from the size of coarse sand to half an inch in length.' Twenty-nine miles sonth of Haddunmati, about in the centre of the channel, we sounded in eleven hundred and thirty fathoms (No. 26), and brought up a mass of large light-green Globigerinae, so abundant that they might be called Globigerina sand. Forty-four miles south of the starting-point we obtained ten hundred and eighty-six fathoms (No. 27), with the same Globigerina sand bottom as in the previous sounding; and two and three-quarters miles from the northern point of Suvadiva ${ }^{2}$ we found eight hundred and ninety-nine fathoms (No. 28), with a coarse greenish coral sand bottom, mixed with fragments of broken shells and corals. The channel between Haddummati and Suvadiva is a very level platean of an averagre depth of somewhat over a thousand fathoms. The

1 It is interesting to find this typical deep-sea oceanie deposit at such moderate lepths, and surrounded, as far as we know, by Globigerinae or Pteroporl deposits. Further south, near Addu, we also found manganese coating fragments of coral at very moderate depths (three hundred and seventy-six fatboms). North, in the Fulidu Channel, fragments of eoral eoated with manganese were obtained in three hundred and seventy-four fathoms. The eoated fragments were mueh in the eondition of similar fragments dredged in the Straits of Florida at abont the same depth.

2 A small nameless faro north of Matu Island. 
slope both of Haddummati and Suvadiva is very abrupt. We ran into nine liundred fathoms at from three to four miles from the edges of the group.

Soundings across the Equatorial Channel, from Suvadiva to Addu, via Fua Mulaku (Pl. Sc, fig. 23).

Six miles south by east from the normal, across Gan Channel, we obtained ten hundred and forty fathoms (No. 29), with a bottom consisting of fine greenish coral sand and Globigerinae. Twenty-one miles from the same starting-point we sounded in twelve hundred and sixty-two fathoms (No. 30), with a bottom of greenish Globigerina ooze. Thirty-one miles from our starting-point, aud about three and one-half miles from Fua Mulaku, we sounded in twelve hundred and ninety-two fathoms (No. 31), the bottom consisting of fine greenish coral sand mised with broken shells. Fua Mulaku ${ }^{1}$ rises quite steeply from the bottom of the channel, separating Suvadiva and Addu.

On our way uorth from Addu we made a sounding about halfway from Addu to Fua Mulaku in ten hundred and forty-eight fathoms (No. 35), with a bottom consisting of greenish Globigerina sand. With the exception of the manganese nodule patch the bottom of the Equatorial and of the One and half degree Channel is oceanic. It is covered with Globigerina sand. Coral sand and Pteropod bottom are only found on the upper slopes, in close proximity to Suvadiva and Arddu.

The two soundings of ten hundred and twenty-seven and twelve hundred and forty-three fathoms, indicated on the chart to the west of our soundings, and of thirteen hundred and twenty-nine fathoms to the east, seem to indicate the existence of a broad plateau of comparatively uniform depth on both sides of the line we ran.

Line south of Addu (Pl. $8 c$, fig. 21).

We hoped to extend a line of soundings from Addu far enough south to show how far its slope extended, and how far the Maldivian ridge or plateau was connected with the Chagos Archipelago (see p. 6). Unfortunately we

1 It was unfortunately too rough for us to attempt a landing on Fua Mulaku, both on our way to and from Addu. 
were unable to carry out this line, and owing to the heavy sea were compelled to abandon sounding at a distance of about three miles south of Addu (Nos. 33, 34), where we sounded in seven hundred and eighteen fathoms, with a bottom of coral sand mixed with fragments of Pteropod shells. At a distance of one and one-half miles south of Addu we found three hundred and seventy-six fathoms (No. 32), with a bottom of small fragments of coral coated with manganese.

Line from Murdu (Ihavandiffulu) to Colombo.

On our way back to Ceylon from Thavandiffulu we took a few soundings to fill gaps in the hydrography of that part of the Indian Ocean. Thirtysix miles from Murdu, in latitude $7^{\circ} 4^{\prime}$ north, longitude $73^{\circ} 34^{\prime}$ east, we obtained fourteen bundred and sixty fathoms (No.77), with a bottom of fine green ooze and Globigerinae. Fifty-five miles to the eastward of this sounding, in latitude $7^{\circ} 4^{\prime}$ north, longitude $74^{\circ} 27^{\prime}$ east, we obtained fifteen hundred and forty-seven fathoms (No. 78), with a bottom composed of fine green Globigerina ooze. Ninety miles still further to the east, in latitude $7^{\circ} 7^{\prime}$ north, longitude $75^{\circ} 46^{\prime}$ east, we ran into nine hundred and sixty-four fathoms (No.79), with a bottom of fine green sticky ooze filled with Globigerinae. These soundings are intercalated with others already on the chart, and make a fairly good section from the Maldives to Ceylon. The soundings on the chart round the northern extremity of the Maldives give the slope of that part of the plateau.

The line towards Colombo brings out clearly the deep wide tongue of the Indian Ocean, of fully fifteen hundred fathoms, which extends northward and separates the Maldivian plateau from the ridge of the Indian continent and its continental shelf.

$\mathrm{Mr}$. Gardiner," while on the steamer "Ileafaee," sounded across three of the western and two of the eastern channels of the central Maldives. His soundings across the western Kudabuvadu Channel, being somewhat to the east of those made by the "Amra," are shallower; one deeper sounding indicates the western terninus of a deeper bight, running west from the centre of the eastern Kudahuvadu Channel.

$$
1 \text { Loc. cit., pp. 9, 352, Pl. X. }
$$


Mr. Gardiner also found thirty-five fathoms' greater depth than is indicated on the Admiralty Chart in the channel between North and South Nilandu. His soundings across the North and South Wataru channels are a few fathoms less than those obtained by the "Amra," as are also his soundings across Wadu Channel.

Mr. Gardiner's soundings across Ariyaddu Channel are well to the eastward of the central line of the channel. They are parallel but to the westward of the axis of the central basin. His lines from the centre of Ari to Wadu Channel, across the central basin, and a southern line from Felidu to North Nilandu, do not indicate any difference in the topography of the southern central basins from that shown by the lines of soundings taken by the "Amra." There are a few discrepancies between the soundings as indicated on his chart, Plate $X$, and the text, but they are not of importance.



Lucas Soundivg Machine. 



\section{LIST OF THE SOUNDINGS}

\section{TAKEN BY THE B. I. S. S. "AMRA," DURING A CRUISE IN THE IIAIDIVES.*}

December 1901-TaNeary 1902.

LINE DUE WEST FRON PASS WEST OF HENBADU NORTH MALE TOWARDS TODDU.

\begin{tabular}{|c|c|c|c|c|c|c|}
\hline \multirow{2}{*}{$\begin{array}{c}\text { Serial } \\
\text { Number. }\end{array}$} & \multirow{2}{*}{ Date 1901 . } & \multicolumn{2}{|c|}{ Position. } & \multirow{2}{*}{$\begin{array}{c}\text { Depth } \\
\text { in } \\
\text { Fathoms. }\end{array}$} & \multirow{2}{*}{$\begin{array}{l}\text { Nature } \\
\text { of } \\
\text { Bottom. }\end{array}$} & \multirow{2}{*}{ Remark8. } \\
\hline & & $\begin{array}{l}\text { Latitude } \\
\text { North. }\end{array}$ & $\begin{array}{l}\text { Longitude } \\
\text { East. }\end{array}$ & & & \\
\hline & $\begin{array}{c}\text { Dec. } 26 \\
\text { “ “ } \\
\text { " " }\end{array}$ & 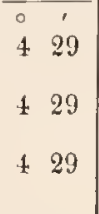 & $\begin{array}{cc}73 & 19.8 \\
73 & 16.5 \\
73 & 13.5\end{array}$ & $\begin{array}{l}120 \\
159 \\
156\end{array}$ & $\begin{array}{l}\text { Coral sand. } \\
\text { Fine clay. Coral } \\
\text { sand. } \\
\text { Fine coral sand. } \\
\text { Grcen globigerinae. }\end{array}$ & $\begin{array}{l}1 \text { mile W. off uormal to Pass } W \text {. of } \\
\text { Hembadu. } \\
3 \frac{1}{2} \text { miles W. off normal to Pass W. of } \\
\text { Hembadu. } \\
\text { Th miles W. off normal to Pass W. of } \\
\text { ILembadu. }\end{array}$ \\
\hline
\end{tabular}

LINE ACROSS WADU CHANNEL FROM PASS WEST OF MALE ISLAND TO WADU SOUTH MALE.

\begin{tabular}{|c|c|c|c|c|c|c|}
\hline 1 & Dec. 27 & $\begin{array}{l}\circ \\
\cdots \\
\cdots\end{array}$ & $\circ \cdot$ & 265 & llard bottom. & 1 mile S. W. off normal to Pass W. of \\
\hline $\begin{array}{l}2 \\
3\end{array}$ & $\begin{array}{ll}\text { " } & \text { " }\end{array}$ & $\begin{array}{l}4.5 \\
.\end{array}$ & $\begin{array}{ll}\tau_{3} & 2 \tau \\
\cdots & \ldots\end{array}$ & $\begin{array}{l}259 \\
236\end{array}$ & $\begin{array}{l}\text { Hard botton. } \\
\text { Broken corals and } \\
\text { shells. }\end{array}$ & $\begin{array}{l}\text { Half-way across Wadu Channel. } \\
1 \text { mile N. W. of Wadu Island, So. } \\
\text { Male. }\end{array}$ \\
\hline
\end{tabular}

ACROSS CIIANNEL BETWEEN SOUTH MALE AND ARI.

\begin{tabular}{|c|c|c|c|c|c|c|}
\hline & & 。 & & & & \\
\hline 4 & Dec. 27 & 356 & $73 \quad 18$ & 180 & $\begin{array}{l}\text { Fine coral sand globi- } \\
\text { gcrinae aud pterop. }\end{array}$ & $\begin{array}{l}2 \text { miles off central part of west face } \\
\text { of So. Male. }\end{array}$ \\
\hline 5 & " " & 355 & $73 \quad 12$ & $20 s$ & $\begin{array}{l}\text { Fine coral sand globi- } \\
\text { gerinae and pterop. }\end{array}$ & $\begin{array}{l}8 \text { miles off central part of west face } \\
\text { of So. IIalc. }\end{array}$ \\
\hline 6 & " " & 354 & 734 & $21 i$ & No sample. & $\begin{array}{l}\text { I } 6 \text { miles off central part of west facc } \\
\text { of } \mathrm{S} \text {. Male. }\end{array}$ \\
\hline 7 & " " & 353 & 7258 & 177 & No sample. & $\begin{array}{l}3 \text { milcs off Kadibudu, centre of east } \\
\text { face of Ari. }\end{array}$ \\
\hline
\end{tabular}

- The positions are all referred to the Admiralty Charts of the Maldives, nos. $66^{4}, 66^{b}, 66^{\circ}$ (sheets $1,2,3$ ). correrted February 1899. See also Plate 1. 
LINE WEST OF ARI.

\begin{tabular}{|c|c|c|c|c|c|c|}
\hline \multirow{2}{*}{$\begin{array}{c}\text { Serial } \\
\text { Number. }\end{array}$} & \multirow{2}{*}{ Date 1901.} & \multicolumn{2}{|c|}{ Positiou. } & \multirow{2}{*}{$\begin{array}{c}\text { Depth } \\
\text { in } \\
\text { Fathoms. }\end{array}$} & \multirow{2}{*}{$\begin{array}{l}\text { Nature } \\
\text { of } \\
\text { Bottom. }\end{array}$} & \multirow{2}{*}{ Remarks. } \\
\hline & & $\begin{array}{c}\text { Latitude } \\
\text { North. }\end{array}$ & $\begin{array}{c}\text { Longitude } \\
\text { East. }\end{array}$ & & & \\
\hline 8 & Dec. 28 & 3 41 & 72 $3 \dot{3}$ & 908 & $\begin{array}{l}\text { Tery fine coral sand } \\
\text { and light grecu glo. } \\
\text { bigerinae. }\end{array}$ & $\begin{array}{l}3 \text { miles W. off normal to Pass south } \\
\text { of Mandu, west face of Ari. }\end{array}$ \\
\hline 9 & " " & $\begin{array}{ll}3 & 41\end{array}$ & 7233 & $I \ddagger 99$ & $\begin{array}{l}\text { Coral ooze and light } \\
\text { blue-gray globigeri- } \\
\text { nae. }\end{array}$ & $\begin{array}{l}8 \text { miles W. off normal to Pass south of } \\
\text { Mandu, west face of Ari. }\end{array}$ \\
\hline
\end{tabular}

LINE ACROSS ARIYADDU CHANNEL.

\begin{tabular}{|c|c|c|c|c|c|c|}
\hline & & & & & & \\
\hline I0 & Dec. 29 & 330 & 7251 & $I \notin 9$ & No sample. & $\begin{array}{l}\text { I mile S. E. of Ariadu Island, So. } \\
\text { face of Ari. }\end{array}$ \\
\hline II & & 326 & 7253 & 231 & $\begin{array}{l}\text { Fraginents of coral } \\
\text { and broken shells. }\end{array}$ & $\begin{array}{l}\text { About half-way across Channel from } \\
\text { Ariadu Island to } \mathrm{N} \text {. face of } \mathrm{N} \text {. } \\
\text { Nilandu. }\end{array}$ \\
\hline I 2 & "“ " & $\begin{array}{lll}3 & 22 \\
-1\end{array}$ & 7253 & 177 & Coarse coral sand. & 1 mile from N. Nilaudu. \\
\hline
\end{tabular}

LINE ACROSS CHANNEL BETWEEN SOUTII NILANIU AND MULAKU.

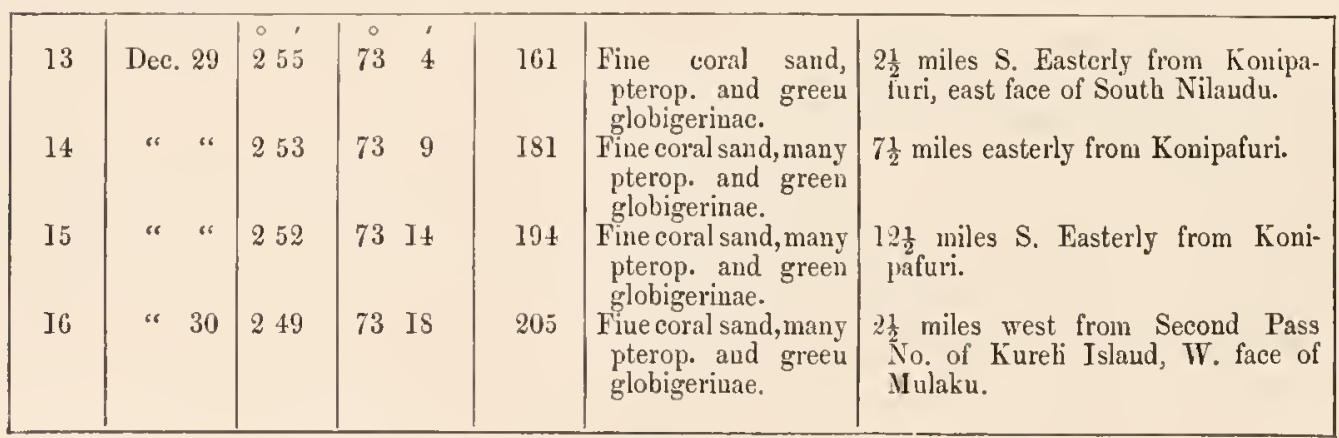

\section{LINE ACROSS KUDAHLVADU CHANNEL.}

Mulaku to Nohtr east face of holumadulu.

\begin{tabular}{|c|c|c|c|c|c|c|}
\hline & & & & & & \\
\hline 17 & Dec. 30 & 241 & 7322 & 403 & $\begin{array}{l}\text { Ilard bottom, clis- } \\
\text { pers indented. }\end{array}$ & $\begin{array}{l}4 \text { miles south of southern face of } \\
\text { Mulaku. }\end{array}$ \\
\hline 18 & ، & 237 & 7320 & 649 & $\begin{array}{l}\text { Hard bottom, clas- } \\
\text { pers indented. }\end{array}$ & $\begin{array}{l}9 \text { miles sonth of Mulaku about half- } \\
\text { wav across to Kolumadulu. }\end{array}$ \\
\hline 19 & " " & 233 & 7319 & 282 & $\begin{array}{l}\text { Hard bottom, clas- } \\
\text { pers indented. }\end{array}$ & 14 miles south of Mulak $\mathrm{v}$. \\
\hline
\end{tabular}


LINE ACROSS VEIMANDU CHANNEL.

Kolumadulu to Hadumiti.

\begin{tabular}{|c|c|c|c|c|c|c|}
\hline \multirow{2}{*}{$\begin{array}{l}\text { Serial } \\
\text { Number. }\end{array}$} & \multirow{2}{*}{ Date 1901.} & \multicolumn{2}{|c|}{ Position. } & \multirow{2}{*}{$\begin{array}{l}\text { Depth } \\
\text { in } \\
\text { Fathoms. }\end{array}$} & \multirow{2}{*}{$\begin{array}{l}\text { Nature } \\
\text { of } \\
\text { Bottom. }\end{array}$} & \multirow{2}{*}{ Remarks } \\
\hline & & $\begin{array}{l}\text { Latitude } \\
\text { North. }\end{array}$ & $\begin{array}{l}\text { Longitude } \\
\text { East. }\end{array}$ & & & \\
\hline 20 & Dec. 31 & 210 & $\begin{array}{rr}0 & 1 \\
73 & 10\end{array}$ & 738 & $\begin{array}{l}\text { Coarse coral sand, } \\
\text { broken sliells. }\end{array}$ & $\begin{array}{l}2 \frac{1}{2} \text { miles off Timarafuri (Koluma- } \\
\text { dulu). }\end{array}$ \\
\hline 21 & $" 6$ & 26 & $73 \quad 13$ & 1119 & Coarse coral sand. & $\begin{array}{l}\text { About } 7 \text { miles off Timarafuri, half- } \\
\text { way across Veimandu Channel. }\end{array}$ \\
\hline 22 & " & . & $\cdots$ & $8 \pm 3$ & No sample. & 2 miles from Pass West of Waduni \\
\hline 23 & of If & 21 & 7319 & 997 & $\begin{array}{l}\text { Coarse coral sand } \\
\text { witl globigerinae. }\end{array}$ & $\begin{array}{l}\text { About } \frac{8}{4} \text { of a mile to N. E. of sound. } \\
\text { ing No. } 22 \text {. }\end{array}$ \\
\hline
\end{tabular}

\section{LINE ACROSS ONE AND HALF DEGREE CHANNEL.}

Iladdumati to Suvadiva.

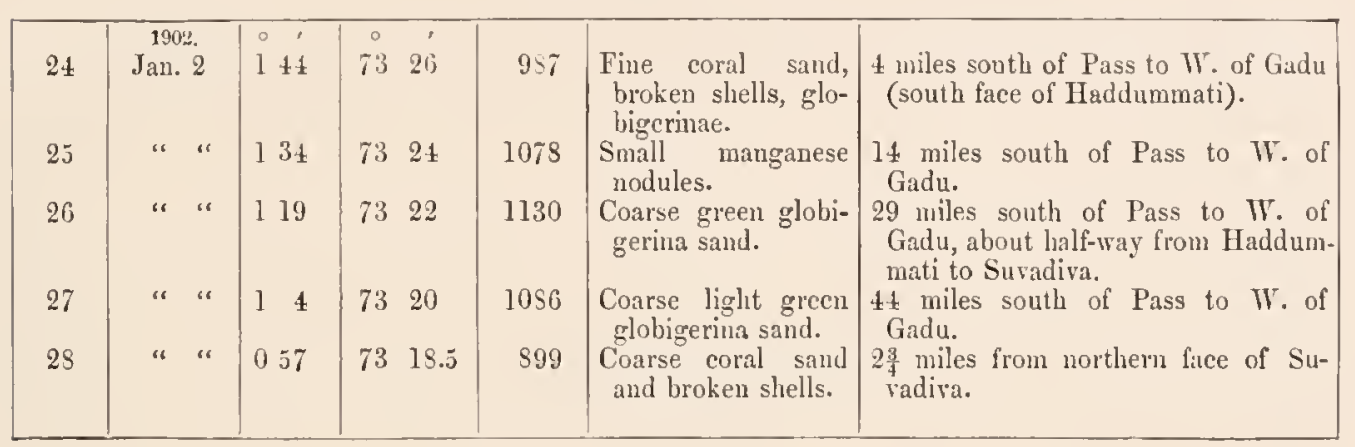

LINE ACROSS EQUATORIAL CHANNEL.

Suvadia to Fua Mulaku and to ADdu.

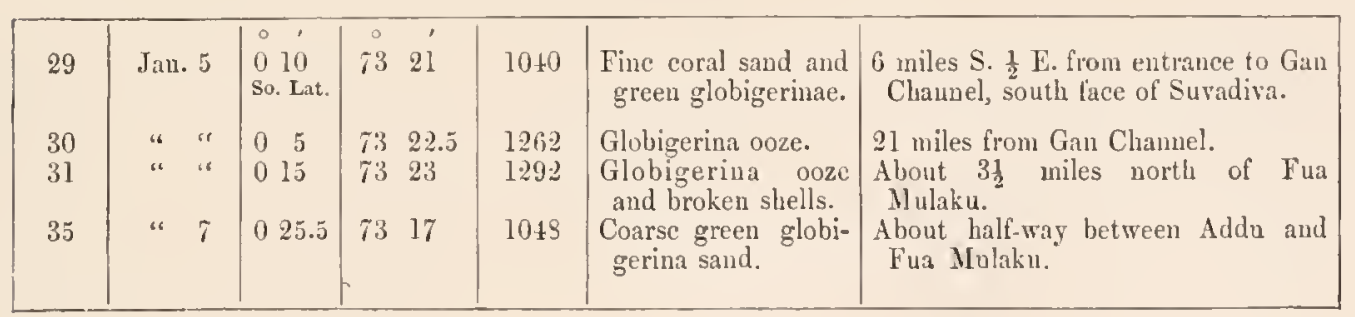

I.INE SOU'TH OF ADDU.




LINE FROII KOLOMADULU TO SOUTII NILANDU.

\begin{tabular}{|c|c|c|c|c|c|c|}
\hline \multirow{2}{*}{$\begin{array}{l}\text { Serial } \\
\text { Number. }\end{array}$} & \multirow{2}{*}{ Date 1902.} & \multicolumn{2}{|c|}{ Position. } & \multirow{2}{*}{$\begin{array}{c}\text { Depth } \\
\text { in } \\
\text { Fathoms. }\end{array}$} & \multirow{2}{*}{$\begin{array}{c}\text { Nature } \\
\text { of } \\
\text { Bottom. }\end{array}$} & \multirow{2}{*}{ Rernarks. } \\
\hline & & $\begin{array}{l}\text { Latitude } \\
\text { North. }\end{array}$ & $\begin{array}{l}\text { Longitnde } \\
\text { East. }\end{array}$ & & & \\
\hline 36 & Jan. 10 & 233 & $\begin{array}{rr}0 \\
72 & 58\end{array}$ & 253 & Coarse coral sand, & $I_{\frac{1}{2}}$ miles off Kandufuri (Koluma- \\
\hline 37 & " & 237 & $72 \quad 58.5$ & 251 & Coarse coral sand, & $6 \frac{1}{2}$ miles from Kandufuri ; half-way \\
\hline 38 & " " & 242 & 7259 & 202 & $\begin{array}{l}\text { Fine coral sand, } \\
\text { grcen globigerinac. }\end{array}$ & $\begin{array}{l}\text { I miles oll Maimbudu (South Ni- } \\
\text { landu). }\end{array}$ \\
\hline
\end{tabular}

SOUTH WATARU CIIANNEL.

\begin{tabular}{|l|c|cc|cc|c|c|c|}
\hline 39 & Jan. 10 & 3 12 & 73 & 23 & 253 & No samplc. & $\begin{array}{c}\text { IIalf-way between Mulaku and Wa- } \\
\text { taru Reef. }\end{array}$ \\
\hline
\end{tabular}

\section{NORTI WATARU CHANNEL.}

\begin{tabular}{|c|c|c|c|c|c|c|}
\hline 40 & Jan. 10 & 318 & $73 \quad 26.5$ & 283 & $\begin{array}{l}\text { Coarse coral sand } \\
\text { and broken shells. }\end{array}$ & $\begin{array}{l}\text { Half-way between Wataru and Fe- } \\
\text { lidu. }\end{array}$ \\
\hline
\end{tabular}

\section{LINE ACROSS FULIDU CHANNEL.}

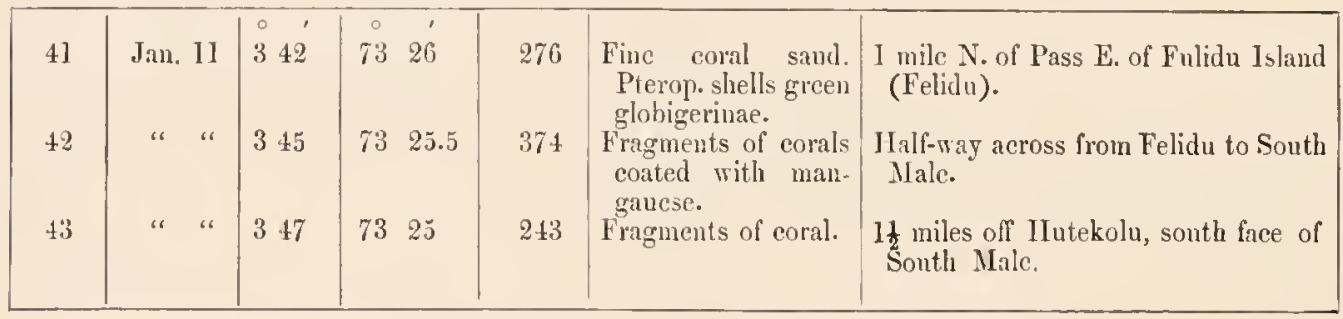

\section{LINE OFF GURU ISLD. EAST FACE OF SOUTH MALE.}

\begin{tabular}{|c|c|c|c|c|c|c|}
\hline & & 10, & & & & \\
\hline 44 & Jan. II & 358 & $73 \quad 32$ & 960 & $\begin{array}{l}\text { Globigerina sand. } \\
\text { Pterop. shells, fine }\end{array}$ & $\begin{array}{l}3 \text { miles cast of Groru Pass, east face of } \\
\text { Sonth Male. }\end{array}$ \\
\hline 45 & " " & 358 & 73 37 & 1238 & $\begin{array}{l}\text { green, cor. saud. } \\
\text { Gray globig. ooze. }\end{array}$ & $\begin{array}{l}8 \text { miles cast of Guru Pass, east face of } \\
\text { South Male. }\end{array}$ \\
\hline 46 & " " & 358 & 7341 & 1270 & Gray globig. ooze. & $\begin{array}{l}12 \text { miles east of Guru Pass, east face } \\
\text { of Soutl. Male. }\end{array}$ \\
\hline 47 & " " & 48 & 7331 & 319 & $\begin{array}{l}\text { Hard botton, clasp- } \\
\text { ers bent. }\end{array}$ & $\begin{array}{l}\text { I miles N. E. of IIuras, N. E. } \\
\text { Pace of Sonth Male off cntrance to } \\
\text { Wadu Channel. }\end{array}$ \\
\hline
\end{tabular}

CHANNEL BETWEEN GAIA FARO AND NORTH MALE.

\begin{tabular}{|c|c|c|c|c|c|c|}
\hline 49 & Jan. It & +42.5 & $\begin{array}{rr}73 & 26\end{array}$ & 100 & $\begin{array}{l}\text { Piece of punice in- } \\
\text { erusted with Bry- } \\
\text { ozoa, Aloac, and } \\
\text { Nullipores. }\end{array}$ & $\begin{array}{l}\text { Half-way between Gaha laro and } \\
\text { North Male. }\end{array}$ \\
\hline
\end{tabular}


LINE FROI GAHA FARO TO GOIFURFEHENDU.

\begin{tabular}{|c|c|c|c|c|c|c|}
\hline \multirow{2}{*}{$\begin{array}{l}\text { Serial } \\
\text { Number. }\end{array}$} & \multirow{2}{*}{ Date 1902.} & \multicolumn{2}{|c|}{ Position. } & \multirow{2}{*}{$\begin{array}{c}\text { Depth } \\
\text { in } \\
\text { Fathoms. }\end{array}$} & \multirow{2}{*}{$\begin{array}{l}\text { Nature } \\
\text { of } \\
\text { Botton. }\end{array}$} & \multirow{2}{*}{ Remarks. } \\
\hline & & $\begin{array}{l}\text { Latitude } \\
\text { North. }\end{array}$ & $\begin{array}{l}\text { Longitude } \\
\text { East. }\end{array}$ & & & \\
\hline & & $\div \quad$ & $\circ \quad \dot{1}$ & & & \\
\hline 49 & Jan. 14 & 444.5 & $73 \quad 19$ & 149 & $\begin{array}{l}\text { Coral sand aud } \\
\text { coarse globigerina } \\
\text { sand. }\end{array}$ & $\begin{array}{l}1 \frac{1}{2} \text { miles west of westem islet of } \\
\text { Gala faro. }\end{array}$ \\
\hline 50 & " "s & 448 & $73 \quad 12$ & 258 & Sample washed out. & 9 miles west of western islet of \\
\hline 60 & " 15 & 450.5 & 735 & 237 & Fine sand, green glo- & 7 miles east of Goifurfeliendu. \\
\hline 61 & "6 & +53 & $72 \quad 59.0$ & 212 & $\begin{array}{l}\text { Fine sand, green glo- } \\
\text { bigerinae. }\end{array}$ & $1 \frac{1}{2}$ miles east of Goifurfeliendu. \\
\hline
\end{tabular}

SOUTH KARDIVA CHANNEL.

\begin{tabular}{|c|c|c|c|c|c|c|}
\hline & & $\circ$, & $\circ$, & & & \\
\hline 51 & Jan. 14 & +48 & $73 \quad 23$ & 241 & Fragments of Oculina. & $1 \frac{1}{2}$ miles north of Gaha faro. \\
\hline 52 & & \pm 52.5 & 7324 & 258 & $\begin{array}{l}\text { Hard botiom, clasp- } \\
\text { ers bent. }\end{array}$ & $\begin{array}{l}6 \text { miles north of Galia faro, about } \\
\text { lalf-way to Karidu lsland. }\end{array}$ \\
\hline 53 & "e " & 457 & 7325 & 295 & $\begin{array}{l}\text { Simall fragments of } \\
\text { pteropod shells. }\end{array}$ & $1 \frac{1}{2}$ miles from sonth face of Karidu. \\
\hline
\end{tabular}

NORTII KARDIVA CHANNEL.

\begin{tabular}{|c|c|c|c|c|c|c|}
\hline 54 & Jall. 14 & $\begin{array}{ll}\circ \\
5 & 0\end{array}$ & $\begin{array}{rr}\circ 3 \\
73 & 25\end{array}$ & 312 & Hard bottom frag- & 1 mile north of Karidu Island. \\
\hline 55 & ، “ & $\begin{array}{ll}5 & 6.5\end{array}$ & $73 \quad 27$ & 197 & $\begin{array}{l}\text { ments or pobie. } \\
\text { Coarse globigerina } \\
\text { sind. }\end{array}$ & 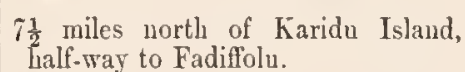 \\
\hline 56 & "6 " & 512.5 & 7328 & $3 \pi 2$ & $\begin{array}{l}\text { Coarse coral saud of } \\
\text { globigerinae. }\end{array}$ & $1 \frac{1}{2}$ miles south of Aligau (Fadiffolu). \\
\hline
\end{tabular}

LINE ACROSS CHANNEL BETWEEN FADIFFOLU AND SOUTH MALOSMADULU.

\begin{tabular}{|c|c|c|c|c|c|c|}
\hline 57 & Jan. 15 & 521 & $\begin{array}{cc}\circ \\
73 & 16.5\end{array}$ & 519 & Coral ooze. Globi- & 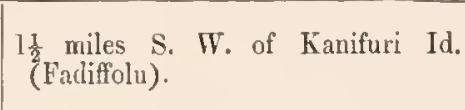 \\
\hline $5 S$ & " " & 519 & 7314 & 366 & $\begin{array}{l}\text { Fine coral ooze. } \\
\text { Few globigerinae. }\end{array}$ & $\begin{array}{l}5 \frac{1}{2} \text { miles from Kauifuri (centre of } \\
\text { Channel). }\end{array}$ \\
\hline 59 & " " & 517 & $73 \quad 11$ & 236 & $\begin{array}{l}\text { Broken shells and } \\
\text { coral sand. }\end{array}$ & $\begin{array}{l}1 \frac{1}{2} \text { miles from Mabaru Id. (S. Malos- } \\
\text { madulu). }\end{array}$ \\
\hline
\end{tabular}

LINE ACROSS CIIANNEL BETWEEN GOIFURFEHENDU AND SOUTII MALOSIADULU.

\begin{tabular}{|c|cc|cc|cc|c|c|l|}
\hline 62 & Jan. 15 & 455.5 & 72 & 55 & 248 & $\begin{array}{l}\text { Coarse coral sand; } \\
\text { broken shells. } \\
\text { Broken shells. }\end{array}$ & 1 mile north of Furudu. \\
63 & " " & 1.55 & 72 & 54.5 & 302 & $\begin{array}{l}3 \frac{1}{2} \text { miles from starting point (eentre } \\
\text { of Channel). } \\
\text { I mile from Maduwari (S. Malos- } \\
\text { madulu). }\end{array}$ \\
\hline
\end{tabular}


THE CORAL REEFS OF THE MALDIVES.

SOUNDINGS WEST OF NORTH MALOSMADULU.

\begin{tabular}{|c|c|c|c|c|c|c|}
\hline \multirow{2}{*}{\begin{tabular}{|c|} 
Serial \\
Number.
\end{tabular}} & \multirow{2}{*}{ Date 1902.} & \multicolumn{2}{|c|}{ Position. } & \multirow{2}{*}{$\begin{array}{c}\text { Depth } \\
\text { in } \\
\text { Fatboms. }\end{array}$} & \multirow{2}{*}{$\begin{array}{c}\text { Nature } \\
\text { of } \\
\text { Bottom. }\end{array}$} & \multirow{2}{*}{ Remarks. } \\
\hline & & $\begin{array}{r}\text { Latitude } \\
\text { North. }\end{array}$ & $\begin{array}{l}\text { Longitude } \\
\text { East. }\end{array}$ & & & \\
\hline 65 & Jan 16 & 527 & i2 $\quad 4$ & 1247 & Sample washed out. & 8 miles $\mathrm{W}$. of Pass south of $\mathrm{Ma}$ \\
\hline 66 & “ & 531 & 7246 & 378 & $\begin{array}{l}\text { Green coral sand. } \\
\text { Globig. and pternp. }\end{array}$ & $\begin{array}{l}1 \text { nile W. of Maregini (N. Malos- } \\
\text { madulu). }\end{array}$ \\
\hline
\end{tabular}

LINE ACROSS CHANNEL BETWEEN FADIFFOLU AND MILADUMNADULU.

\begin{tabular}{|c|cc|cc|cc|c|c|c|}
\hline 67 & Jan. 17 & 5 & 33 & 73 & 23 & 342 & $\begin{array}{l}\text { Hard bottom, clasp- } \\
\text { ers bent. } \\
\text { Sample washed out. }\end{array}$ & $\begin{array}{l}\text { I mile N. of Il urawali (F.diffolu). } \\
\text { 4 miles N. of IIurawali (centue of } \\
\text { Channel). } \\
\text { 1 mile S. of Karema (Miladumma- } \\
\text { dulu). }\end{array}$ \\
\hline
\end{tabular}

LINE ACROSS CHANNEL BETWEEN MILADUMMADULU AND NORTII MALOSMADULU.

\begin{tabular}{|c|c|c|c|c|c|c|}
\hline 70 & Jan. 17 & 548 & 736 & 412 & Coral sand. Broken & 1 mile W. of Mavila (Mliladumma- \\
\hline 71 & " " & 547.5 & 733 & 513 & Fine coral sand and & $\begin{array}{l}4 \frac{1}{2} \text { miles W. of same (centre of } \\
\text { Clianncl). }\end{array}$ \\
\hline 72 & " " & 547 & 7259.5 & 286 & $\begin{array}{l}\text { Fine coral saud and } \\
\text { globigerinae. }\end{array}$ & $\begin{array}{l}1 \text { mile east of Furidu (N. Malus- } \\
\text { madulu). }\end{array}$ \\
\hline
\end{tabular}

CHANNEL BETWELN MILADUMMADUI,U AND NORTI POINT OF MAKUNUDU.

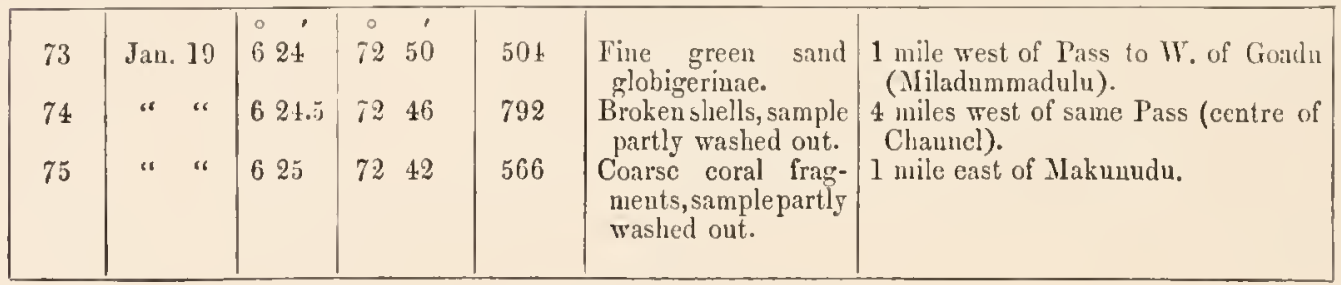

\section{GALLANDU CHANNEL.}

\begin{tabular}{|l|c|cc|cc|c|c|c|}
\hline 76 & Jan, 20 & 6 & $5 \pm$ & 72 & 56 & 251 & $\begin{array}{l}\text { Fragments of coral } \\
\text { in jaw of clasper. }\end{array}$ & $\begin{array}{c}\text { In centre of Gallaudu Chamel separ- } \\
\text { ating Tiludumuati and lhavandiffulu. }\end{array}$ \\
\hline
\end{tabular}

FROM IHAVANDIFFULU TOWARDS COLOMBO.

\begin{tabular}{|c|c|c|c|c|c|c|}
\hline & & & , & & & \\
\hline 77 & Jan. 20 & 7 & $73 \quad 34$ & 1460 & $\begin{array}{l}\text { Fine green ooze, glo- } \\
\text { bigerinae. }\end{array}$ & $\begin{array}{l}36 \text { miles E. of Beramundu (Ihavan- } \\
\text { diffulu). }\end{array}$ \\
\hline 78 & & 7 & 7427 & 1547 & $\begin{array}{l}\text { Fine green globi- } \\
\text { geriua ooze. }\end{array}$ & $\begin{array}{l}91 \text { miles } \mathrm{E} \text {. of Beramundu (Ihavan- } \\
\text { diffu]u). }\end{array}$ \\
\hline 79 & " " & 77 & $75 \quad 46$ & 964 & $\begin{array}{l}\text { Fine greeu globi- } \\
\text { geriua ooze. }\end{array}$ & $\begin{array}{l}181 \text { miles E. of Beramundu (Ihavau- } \\
\text { diffulu). }\end{array}$ \\
\hline
\end{tabular}




\section{DESCRIPTION OF THE ATOLLS.}

\section{North Male.}

Plates 1, 3, 4; 8a, fig. 6; 8b, figs. 11, $19 ; 8 \mathrm{c}$, fig. 24; 2-18; 19, fig. 1 .

Norti Male is irregularly triangular in form (PI. 4), with a western convex side; the northwestern and northeastern faces are concave; it is about thirty-two miles long with a greatest width of twenty-two miles. Orer fifty islands, rings, and banks are enclosed within the basin of North Male; it is flanked both on the east and west faces by large faros, only on a few of those of the west faces are found islets. The principal islands are on the southeast face from Mirufuri to Wilingili Island to the west of Male Islimol. There is no gronp in the Maldives in which there is such a large number of rings (faros) cropping up in all directions to the surface or within three or four fathoms fiom the surface. These submarine rings or embryo submerged atolls are specially numerous inmediately towards the north of Miale Island and in the northern part of the group to the southwest of Mirufuri (Pl. 4). A great number of small banks are dotted over the central area of North Male, either reaching the surface or awash or at depths of three to four fathoms. These banks as well as the rings generally rise from a depth of from twenty to thirty fathoms. There are comparatively few islands scattered through the central area of North Male. Mr. Gardiner has noticed marked discrepancies between Moresby's Charts of North Male and the positions he assigned to several of the reefs. This may be due to the large areas of that atoll left unsurveyed within Noresby's lines of sounding and the difficulty of locating from a low level rings and low islands which become clearly outlined from a higher station like the brirge of a steamer. Wherever we followed lines of somdings we usually found the chart wonderfully accurate, but naturally in the unsurveyed portions we were frequently at sea. 
The rings of the inner parts of North Male and some of the islands on the onter rims are all built of sand, as has also been observed by Mr. Gardiner. But on many of the outer islands remnants of elevated reef rock are found forming the base behind which the sandy growths of the islands have been piled up since the slight elevation of the Maldives took place.

Mrr. Gardiner considers North and Sonth Male to be in a very stable conldition. ${ }^{1} \quad$ On North and South Male as well as Mulaku there is comparatively little land on the east side and still less on the west side of these atolls (Pls. 3, 4, 5).

The charncter of the faros which follow in rapid succession on the southeast face of North Male varies but slightly. They differ in size, in the width of the reef flats, in the size and depth of the lagoons, in the number and dimensions of the islands on the faro rims, and in their position with reference to the sea or inner face (Pl. 4).

The east point of North Male is formed by the northern part of the wide outer flats of an elongated faro about seven miles in length and two at its greatest width. The inner rim of the faro is quite narrow; at its southem extremity are found three small islands and a small secondary lagoon enclosed in a sharp spit forming the north side of the deep pass, with from twenty to twenty-seven fathoms, separating this faro from the one immediately to the sonth of it. Mirufuri and Difuri are two small islands on the northern parts of the east face of this eastern faro. The soundings in the lagoon of the faro vary from four to seven fathoms (Pl. 4).

Tulusdu, the island on the northeastern face of the next faro, is close to the pass; the deepest part of the lagoon of the faro is near the northern extremity. The rim of the faro is nearly of uniform width on the two faces except at the northern and the sonthern points of the faro where the flat is flanked by a wooded island (Pl. 4).

The outer edge of the faros on the southeast face of North Male are all flanked by lines of coral boulders or small horse heads of modern reef rock. The lagoon reef to the sonth of Tulusdu faro is marked by the small size of its lagoon and the central position of the principal island of the faro flats. Inma, the larger faro to the south, is a wide reef flat covered with from one

$$
1 \text { Loc. cit., pp. 402, } 403 .
$$


to six feet of water, with two large islands in the axis of the flat. The lagoon of this faro has practically been filled up by the washing into the central basin of coral sand from both the sea face and the lagoon side during the prevalence of the northeast or southwest monsoons. A small faro with an islet and a sand-bar at its eastern extremity occupies the central part of the deep pass separating it from the faro to the north. We find on the chart twenty-one fathoms in the channel on either side of these obstructions (Pl. 4).

The great faro at the horn of the southeast face of North Male is separated from Inma by a pass nearly three miles wide. It is well seen from off the northern extremity of Hulule, where one can take in at a glance the whole length of the lagoon and look over the flats to the enst of Hulule and to the great reef flats forming the northern horn of the faro. The northern and southern parts of this southernmost faro (Pls. 10, 11) are occupied by wide reef flats; a small island, lying diagonally across the flats, occupies the central part of the northern horn of Hulule, a long island flanks the western face of the sonthern horn, and a small islet lies to the sontheast near the southernmost extremity of the faro. Near the small southeru islet a line of recent reef rock rises inside of the bonlder belt, from a foot to eighteen inches above the reef flat. It is one of the ontliers of the older reef flat conglomerate which has been denuded to its present level. This ridge is eroded, deeply pitted, undercut, and honeycombed, and is the first indication we saw of evidence of a slight elevation of the coral reef of the Maldives in most recent times, judging from the character of the reef rock as it appears there and at other points in the group. The outer eastern edge of Hulule faro is flanked by a boulder belt of fairly large blocks. The belt passes round the southeast horn and extends along the face of the little islet on the edge of the faro near its southeast horn. This faro is in reality an atoll, fully as large as many a Pacific islancl atoll with wide reef flats, flanked on the sea face by coral boulders enclosing a shallow lagoon and with islands on the rim flats.

The southern part of Inma pass is occupied by a small faro and an islet to the north of it. The small faro is separated from Furena by a narrow pass with thirty fathoms of water. In the main ehannel the depths vary from 
twenty-four to thirty-five fathoms. Another faro in the pass to the north of Imma (Pl. 15, fig. 2) is crescentic. One side is formed by an island extending into a sand-bar, while on the other the island extends into a submerged rim; the horms of the crescent are widely separated, enclosing a deep lagoon. 'The southern part of 'Tulusdu faro as seen from the west appears like a narrow, shallow lagoon, enclosed between two strips of shallow flats.

We steamed round a large faro with a wide reef flat rim nearly a mile and a half in diameter, abont four miles to the west of Difuri, and with nine fathoms in the lagoon; a wide flat makes off the eastern part of the rim of this faro. The great Difuri faro has even more than Tulusdu and Inlule the chanacteristics of an atoll; as seen from the west, the lagoon studded with coral heads is seen to be separated from the immer waters of North Male by a narrow rim flat extending from the northern horn to the soutlrern extremity. The eastern reef flat rim is in places nearly a mile wide. To the north of this lagoon reef in the centre of the pass (Pl. 4) is situated a long comma-shaped faro nearly three miles in length and perhaps half a mile wide at the club.

'The faros of North Male are most irregular in shape, some are crescentic, others more or less rectangular, others somewhat polygonal, or dumb-bellshaperl, or circular with long spits, or they have assumed the shape of a long series of loops or cusps forming angular spits. An examination of the chart of North Male (Pl. 4) will show their great diversity in shape and size. Yet it is a simple matter to reduce these protean shapes to a simple and common origin. 'The circular furos occur in the sheltered waters of North Male, where corals are left to grow with but little interference from the monsoons or currents which have tended to modify their ontlines on the outer rim parts of the Maldive plateau, where they are exposed to the full force of the prevailing winds.

To the west of the comma-shaped faro we came upon a maze of bauks and small faros; that part of North Male not being as yet surveyed, we did not dare to push north, but shaped our course for the west face of North Male. We found the western slope of Difuri faro much less abrupt than that of other faros we had examined. About quarter of a mile from the 
edge we were in nine to ten fathoms, the slope rmming very gradually up to the edge of the flat into from four to six feet of water at three quarters tide. There was a fine growth of corals on the western face in marked contrast to the condition of corals usually found on the flats and slopes within the lagoons of the Pacific atolls. Nothing shows, perhaps, as plainly as this the atoll character of these numerous faros, scattered over a great plateau. In the lagoon of the faro, coral heads occm occasionally in small patches as well as on the rim flat, where they are separated by wide lanes of sand. In the lagoon of the faros the corals are retarded in their development by the same cause, which acts so efficiently in the lagoons of atolls of other coral regions. On the onter rim flat there are fewer patches of living corals than on the western rim. The onter sea edge of the reef flat is edged with large coral blocks and boulders, more or less pitted and honeycomber; these in some cases formed ridges of modern reef rock near the outer edge of the boulder belt, more or less undercut, rising a couple of feet at most above the level of the onter edge of the rim, and indicating perhaps an elevation of a few feet, these ridges are outliers of a former higher plane of the outer rim, which has heen cut down to its present level. The depths of the rims of the rings and of the sand banks varies greatly. They are found at all depths from fifteen fathoms to the surface; where they have grown up to within six or seven fathoms of the surface, the color of the water over the rims becomes an 'excellent guide of their depth below it.

It is difficult to form an accurate opinion regarding the junction or coalescence of adjoining faros on the outer faces of such an enclosed basin as the great lagoon of North Male. It wouls seem natural to consider some of the longer and narrower faros which form the onter face of the eastern horn of Felidu, parts of the eastern face of Mulaku, of the outer rim of Kolumidulu and of Inddummati, as having originally been composed of a large number of small faros or banks separated by comparatively shallow passes. With the growth of the corals from the two sides those passes become gradually choked, and may finally have become united to form the long narrow reef flats just mentioned, which with the exception of the existence of small lagoons now show so little trace of their former composite condition. 
However, when we speculate upon the origin of the larger faros of some of the northern groups, as Ari, North Male, Malosmadulu, and Tiladummati (Pls. 2, 3, 4), the conditions now existing do not warrant the conclusion that they have been formed by the junction or coalescence of adjoining faros. The great size and depth of the lagoons of some of the faros, the depth of the passages separating them, their great width, - all these factors indicate that the faros have grown from depths of eighteen to twenty fathoms on secondary elevations of the greater plateau, with much the same shape they now have. In their upward growth they have been modified so as to become faros differing in the width of their rims, their outline, the depth of the lagoons, the number of banks and islets or islands thrown up on the rim flats; or the lagoons may even have been completely filled, and the faro changed to a great reef flat or even an island steep to with a fringing reef, where all trace of the original faro has been lost. Of course we do not deny that faros may join in time if they were originally separated by comparatively shallow passes. This we see taking place by the growth of corals in cusp-like spits from the slope of a rim flat, which enclose shallow parts of the adjoining waters - a process somewhat similar to that by which adjoining islands on wide reef flats become conneeted into a larger island from the throwing out of sand-spits or of shingle-spits, either on the lagoon or the sea face of the outer rim of an atoll, forming great bays which become eventually filled; a process which takes its greatest development, perhaps, in the Ellice, Gilbert, Marshall Islands, and also oceurs in other groups of atolls in the Pacifie.

An examination of the charts (Pls. 2-6) shows a few instances where adjoining faros in the interior of Ari, North Male, and the groups just mentioned may have coaleseed. The distance separating the rings which crop up within the enclosed area of Male and Ari furnishes no evidence that they have been formed by the coalescence of adjoining faros. The irregularly shaped banks and faros are additional evidence of their having grown up on secondary inequalities of the plateaus of these groups.

The western rim of one of the rings on the northwest face is circular; the other is digitate with deep indentations cutting into the wide irregular eastern flat (Pl. 4). 
On the outer line of faros of North Male, Malosmadulu, and Ari (Pls. 3, 4), with the exception of the reef flat bounding the southern face of the latter, and in the maze of coral heads and banks of its southeastern face and the reef flat on the northwest face of North Male there is no evidence of the coalescence of adjoining faros; they stand out separately and distinctly, much as they originally arose from the plateaus upon which they are scattered.

Steaming sonth from Mirufuri along the eastern face of North Male, we could see across the outer line of faros an number of well-wooded islands in the interior of the great enclosed sheet of water to the westward from Asdu and south to the islands to the northwest of Male Island and near it. Such a land rim as we have described from Mirufuri to Male gave to the so-called lagoon of North Male a totally different character from that of any other atoll I had previonsly seen. The existence of well-wooded islands in the interior of the great enclosed sheets of water of the Maldives we subsequently found to be a distinctive feature of the archipelago. 'The outer edge of the faros on the east face of North Male is clearly marked at low tide by a belt of boulders or by the surf breaking on the outer face of the wide reef flat; the depth of the rim below the surface can readily be detected from the color of the water on the flat. The inner edge, at the time of the northeast monsoon, is only marked by the coloring of the inner flat, a yellowish-green belt of varying width separating the light blue of the lagoon of the faro from the deeper, darker-colored water of the larger enclosed sheet. Extensive patches of corals spread over both the inner and onter reef flats of the faro, gradually becoming thinner and more distant and less luxuriant as they recede from the outer edges. Their presence can be detected at a considerable distance from the dark, more or less purple brown coloring of the patches.

The sonthern corner of North Male is occupied by the island of Male, on which is built the capital of the Maldires. The greater part of the island is covered by an old fort erected by the Portnguese and Dutch during their occupancy of the islands. To the west and south extends a wide reef that dished near the outer edge, while on the northern and eastern faces the island is steep to. Extensive works have at different times been built 
either as breakwaters or bastions, which conceal the structure of the island, but it is identical with that of many similar islands throughout the group.

Advantage has been taken of a narrow reef flat on the northwest face of the island to build a breakwater enclosing a small harbor with suffi.

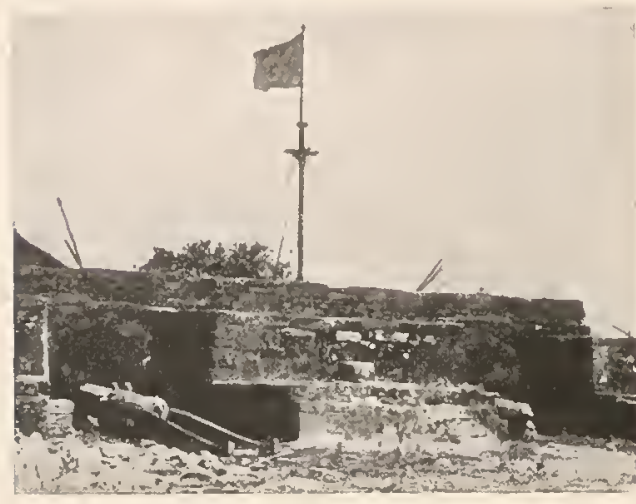

Bastion at Male. cient depth to shelter native boats of considerable size. The southern face of Male Island is also flanked on the outer edge of the somewhat dished reef flat by a belt of angular coral blocks more or less eroded and weathered, forming a low wall.

From our anchorige off Male we conld see to the northwest two of the remarkable light green rings which are so characteristic a feature of the coral physiognomy of the Maldives (Pl. 4). These rings and their endless modifications, due to their age, their size, their position on the primary or secondary plateaus of the group, their exposure to the prevailing winds, their depth from the surface, give us the key to the structure of the coral reefs of the Maldives. ${ }^{1}$

The only structures to which they can at all be compared are the small atolls known as "boilers" in the Bermudas, and which flank the south shore near Sinkey Bay. ${ }^{2}$ But the diminntive atolls of the Bermudas owe their origin to other causes than those which have built the rings of the Maldives. The latter are atolls, and no matter what their size may be, they are built up by corals, while in the Bermudas these small atolls are really only large pot-lioles, the outer rim of which is protected by the incessant growth of Serpula and Algre on the edge. All the faros of which the nucleus consists of elevaterl reef rock planed down to the level of the sea have

1 Darwin * considers the ringlike structure to be eontingent on breaches into the lagoon being wide and numerous, thus placing the inner side of the rings in the same condition with the outside of an ordinary atoll exposed to the sea. Hence the margins have grown vigorously outwards, while they have grown upwards during the subsidence to which, accorling 10 Darwin, the whole arebipelago has been subjected, subsidence and upward growth converting the central space of each little reef into a small lagoon.

2 A. Agassiz, Bull. 11. C. Z., Vol. XXVI., No. 2, Pls, $22-26$.

* Loc. cit., p. 141. 
increased by sand being heaped up in the direction of the prevailing winds or eurrents, forming horns eventually uniting and enclosing a part of the greater inner lacroon. On the face of the banks, corals obtained a foothold and consolidated the rins of the firros. Their mode of formation ean best be explained when tracing the changes undergone by the rings.

In thirty fathoms at our anchorage off Male Island the bottom was covered with fragments of broken eoral coated with Nullipores, or was quite hard, having been swept comparatively elean by the strong current rushing in and ont of North Male throngh the southeast ehannel.

At our anchorage off the west face of Difuri abont three-quarters of a mile from the rim of the furo, we found coarse coral sand in twenty-one fathoms of water; a hanl of the drerlge made in about twenty-seven fathoms nearly in the centre of North Male brought up coral sand mixed with more or less sticky ooze and broken shells. In all cases we found quite a different bottom from that which characterizes the bottom of a Pacific lagoon.

The greatest depth of North Male is thirty-seven fathoms. The majority of the soundings indicated vary from twenty-five to thirty-one fathoms.

As a type of an inner island, we examined a small well-wooded island (Pl. 9, fig. 2) which rises in the middle of the southeast passage into North Male with nearly thirty fathoms on either side of it. The island is elliptical, and is placed on the northwestern horn of an elliptical flat which stretehes out in a southeasterly direction. The flat slopes very gently to the sea, is edged on the outer rim by a sink forming a shallow diteh of varying width, flanked by coral boulders or masses of beach rock extending as an irregular rall along the greater part of the onter edge of the reef flat. The greatest width of the reef flat is from two hundred and fifty to three hundred feet. It diminishes gradually in width to the northwestem comer, where the island is steep to. Corals grow in great abundance at a depth of from five to three fathoms upon the steep slopes of the reef flat; they grow with less profusion to six or seven fathoms, where they are separated by wide lanes and patehes of sand which eventually cover the whole bottom at a depth of from eight to nine fathoms. From the three-fathom line, they also diminish in number towards the surface and spread over the edge of the tlat, which is partly bare at low water; they extend but 
a short way over it, the greater part of the flat being covered by dead corals overgrown with Nullipores. The sand beaches surrounding the island are steep, from six to seven feet in height. The central part of the island is lower than the top of the beaches which surround it, forming a shallow sink from twelve to eighteen inches or more in depth. Considerable moisture aceumulates in this central sink, and in the rainy season a pool is probably formed of more or less brackish water. This structure is most characteristic of the islands of the Maldives, whether they occur in the interior of the great sheets of enclosed waters or on the outer rims of the plateaus. The sink has been formed by the washing up of the beaches round a central area, as we have seen it in the Paumotus and elsewhere in other Pacific atolls. Before the vegetation became too dense, beach sand was blown towards the interior and partly filled the central area, until this was prevented by the growth of bushes and shrubs, when the beaches merely increased in height and the sand of the upper ridge of the beach was driven sparingly towards the centre of the island, or its further passage stopped by the belt of denser vegetition which lad come up on the ligher parts of the coral sand beach. The island of Male has crradually developed and been formed much in the same manner as this island.

The corals growing on the slopes of this island are marked for their luxuriance; they grow as abundantly as they do on the sea face of any atoll. This is in striking contrast to their scanty development in the interior of typical lagoons. It can readily be explained from the great depths of the passes and the great mass and purity of the water passing into the interior of the enclosed basin of North Male. Throughout the northern and central Maldives corals grow in great profusion on the slopes of the islands and faros within the enclosed basins of the group. The branching corals consist mainly of species of Madrepores, of Pocillopores, and Millepores. While the massive corals are usually Astreans, Porites, and the like, Mrandina are not common.

The vegetation of this island is remarkably fine. In spite of its small size large trees are found upon it. It is a favorite resort for flying foxes: its aspect is in striking contrast to the meagre flora found on similar islands in the Paumotus, Ellice, or Gilbert Islands. 
The first ring we examined (Pl. 13) was nearly circular, about laalf a mile in diameter. It rose quite abruptly from a depth of nearly twelve fathoms and sloped very gradually to the general level of the bottom of the greater lagoon (thirty fathoms); the outer edge of the rim being about one hundred and fifty feet from the vertical at the base of the rim slope. The width of the rim varied from sixty to one hundred and seventy-five feet, the general depth of the rim varying from two feet to two fathoms; the slope of the rim towards the interior of the enclosed lagoon was even steeper than the outer slope. On the outer face corals grew in great profusion from the very base to the edge of the rim and in patches on its surface. The inner slope as well as the bottom of the lagoon consisted of coral sand driven across the rim and gradually widening the eastern or western rim according to the direction of the prevailing monsoon, the process at the same time filling the central lagoon, which in this case was about seven fathoins in depth.

The corals were of the same genera as those growing on the island in the southenst pass into North Male, and fully as luxuriant. We did not observe any corals on the bottom of the small lagoon ; they must be killed by the inflowing sand. A few patehes of corals extend from the outer base of the ring into somewhat deeper water, but they fast disappear and the slope consists again of fragments of coral and coral sand. Towards the northeastern face of the rim lat the sea breaks, the depth of a part of the rim not being more than a few inches below the surface. The sand of that part of the rim is kept greatly agitated, and we should expect there the early formation of a sand-bar or diminutive islet on the rim flat of the ring.

The next faro we examined represented a stage in the formation of an island considerably more arvanced than that of the simple ring rim enclosing a comparatively deep lagoon. It consisted of an extensive elliptical flat (Pl. 15, fig. 1) with but three or four feet of water at low tide, its rim flanked on the east by a small narrow island covered with bushes rising from a steep coral sand beach; towards the west a small shallow lagoon, judging from the color of the water, occupies a part of the reef flat.

It seems a simple process to follow the transition of the first ring we 
described to such a larger reef flat. Its original large lagoon has been filled up and left a diminutive pool; the incipient sand-bar has become a constantly growing islet and is covered with scant vegetation derived from the adjoining faros. It needs but an additional stage in the filling of the lagoon and increase in the size of the islet to reach the condition of the island we described lying in the southenst pass to the northeast of Male Island. With the growth of the land larger trees will obtain a focthold, and the original lagoon become transformed into a great reef flat similar to that of the former island. This island rose quite abruptly from a depth of twenty-five fathoms much as did the island to the eastward of Male. It is evident from the mass of broken and dead corals towards the base of the outer slope that the rim flat increases in width by the reaching out of the outer talus.

Corals obtain a foothold on the upper slope of the flat and form extensive patches reaching over its surface from the outer rim. The reef flat gradually becomes covered with fragments and small masses of coral coated with Nullipores which bind the whole together.

These rings are apparently formed by the upward growth of eircular or elliptical patches of corals oceupying slight elevations above the general level of the surrounding plateau. These patches may grow up uniformly, forming elliptical banks, or they may grow as annular structures, the corals of the outer face only rising towards the surface, while those in the central part of the patch are killed either from want of foor or of clean sea water, or are choked by the sand derived from the dead corals of the outer rim, which is washed into the interior and covers the corals. The outer ring growing faster than the inner dish is filled, a central lagoon is formed, this is filled in time after the ring rim lias reached the surface; the amnular structure is then changed into a bank from which all traces of the original lagoon have disappeared and upon the outer rim of which sand-bars or islets or both have formed. There is thus eventually formed either an island surrounded by a more or less extensive reef flat or an island and reef flat with the remnants of a lagoon, or an island or islet on the rim of a ring with a well-marked and deep lagoon. all different stages of growth of an annular coral reef formed upon a base laid within the range of depths 
at which reef-building corals begin to grow. The final stage, that of a well-wooded islind steep to, is well seen in the three small islands we examined lying to the northeast of the first ring we visited in North Male waters. These are all steep to ; the original wide reef flats are reduced to a narrow insignificant strip flanking the islands.

About three miles to the northwest of Male Island rises an interesting faro with a small islet on the eastern rim of its lagoon, that has been reduced to a minimum, nothing but a small hole being left of the original lagoon, which has gradually been filled by coral sand driven into it over the summit of the reef flat rim until there is only an insignificant pool left to indicate the original lagoon. Fine patches of corals extended from the onter edge over the reef flat; a belt of low vegetation has found a foothold on the islet of the faro which is protected by coral sand benches.

Vehamafuri, another large faro to the northwest of Male Island, deserves mention for its narrow rim; its greatest diameter is fully a mile; the enclosed lagoon has a greatest depth of twelve fathoms. It rises from a deptlı of twenty-seven fathom\%. To the westward rises another much smaller circular faro, less than a quarter of a mile in diameter, the rim of which is fully three fathoms below the surfice. On our way to the island of Tulagiri from V'ehamafuri we passed a number of faros with light green rims and darker bluish-colored lagoons of different shades varying according to the width of the rim, its depth below the surface, and the depth of the lagoon.

The island of 'Tulagini (Pl. 16, fig. 2) is on the sonthem rim of a small faro, not quite half a mile in dianeter; its southern rim is remarkably narrow and covered with a great many patehes of corals. To the eastward of this faro could be seen the outline of a circular faro, nearly a mile in diameter. Two others somewhat elliptical rose to the northward. Nearly halfway between Tehamafuri and Tulagiri rises Bundusi and a small island to the south of it; both are steep to; the latter is nearly a mile in diameter with extremely narrow reef thats.

Between Tulagiri and Kudahitty we passed six faros. With the exception of the northern one, which is triangular in shape, they are circular or elliptical, with fairly wide rims and moderately deep lagoons. Kudahitty 
(Pl. 17, fig. 1) is a small island on the eastern edge of a small lagoon, less than a quarter of a mile in length. Hitty (Pl. 17, fig. 2) is a small island a couple of miles east of the great faro on the central part of the western edge of North Male; it is on the southern extrenity of an elliptical ring enclosing a deep lagoon. Hitty is flanked by a hook-like faro, with a broad eastern rim and open to the north. To the north we passed a similar double faro on oul way to Hembadu. A small island covered with trees occupies the greater part of the rim, which separates the two loops of the adjoining faros.

On our way across the Male group, we passed a number of coral patches or sand-bars of irregular or circular shape, at varying depths below the surface, the color of the patch indicating fairly its depth below the surface. Many of the flats were covered here and there with irregular patches of corals, but as a rule they were not flomrishing and not to be compared with the vigorous growth on their slopes.

One of the rings we passed enclosed a well-marked blue lagoon indicating at least seven to eight fathoms; its rim extended to the westward in a long spit awash, on which sand-bars were forming. The spit was separater by a deep channel from a narlow sand bank covered with but a few feet of water. To the north rose small faros and banks, on the rims of which corals were growing in great profusion. One large circular faro was specially noted for its diminutive lagoon, the only indication left of a former larger lagoon which has gradually been filled up by the sand driven from both sides across the lim, and deposited on the bottom of the lagoon during the prevailing monsoons.

To the south of Hembadu we could see three interesting stages in the development of a faro. In the inmerliate foreground rose a large, irregularly circular reef flat of a light green color, its rim edgred with closely packed great violet brown patches of corals, extending down along the outer slopes of the faro into twelve or fifteen fathouns; on the northern face a small, bare sand bank had been thrown up on the reef rim flat. 'To the west a shallow lagoon of considerable size occupied the greater part of that side of the faro. Immerliately to the north of this rose a small elliptical bank, its surface covered with a magnificent growth of corals in six to seven feet 
of water, and a small sand bank thrown up on the outer edge of the rim where the corals were awash. Still further, a large bank of the same character, but with a sand bank rising a comple of fect, and on which a few grasses and shrubs harl obtained a foothold; while in the distance-a similar bank had been blown to a sufficient size and height to be covered with small trees and be surrounded by a considerable belt of low bushes.

Passing out of North Male through the wide passage west of Hembadu, we could not fail to compare it with the narrow passes which characterize the entrinces into so many of the Pacific atolls. Hembadu Pass is fully four miles in width, with from seventeen to twenty-two fithoms in depth; and flanked by low faros, it gave one the impression of still greater width and marked more sharply the contrast to such narrow passes as those of the Pammotus, Ellice, Gilbert, and more northern atolls.

The passes into the central area of North Male are only low portions of the rim separating the more elevated parts of tlic plateau, upon which the faros have grown either on the onter face or in the inner area of North Male. An examination of the soundings within North Male as well as those of any other group of the central and northern Maldives shows how great are the irregularitics of the bottom of the secondary plateans of the Maldives. To the westward of Hembadu the bottom is very uneven; on our way ont of North Male through the wide pass to the west of Hembadu, we found rapid changes in depth, and could distinctly see the extension of the coral patches indicated on the charts scattered over a.good part of our track. They extended all the way across the northern part of the pass, west of Hembadu. Off the eastern face of the faros of the western face of North Male one passes rapidly from fifteen to thirty fathoms; in the vicinity of an agglomeration of small faros the depth varies from twenty to thirty fathoms. The lines of soundings as they exist throughout North Male indicate a series of elevations rising somewhat abruptly at from twenty-four to twenty fathoms; they constitute the base upon which the banks, faros, or islands and islets which stud North Male have been built up. This indicates a condition of the bottom of the central area of North Male different from the great level and unbroken flats which characterize the bottom of the lagoons of the Pacific atolls. There the great fall in 
depth occurs close to the lagoon face of the outer rim and it slopes suddenly to the general dead level of the great central area of the lagoon. ${ }^{1}$

To the south of Hembadu Pass the faros on the west face of North Male are very similar in structure, though greatly differing in shape and size. The largest one, fuur miles in length by one and a lalf wide, immediately. to the south of the pass, is edged on the western rim by a wide reef flat, on the eastern by a narrow rim. A small island covered with low bushes rises in the southern part of the western rim of the reef flat. The reef Hats enclose a large lagoon nearly as long as the faro. Rumning south, parallel with the western face of the outer faros, all the way to Wilingili Island, on the sonthern face of North Male, we remained in sight of a number of faros of all sizes and shapes. Their western rims are generally wider than the eastern, with deep blue or lighter-colored lagoons, according to their depths, often edged on the east by extremely narrow rims, some of them a mere thread but a few feet in width, the wider reef flats being always the outer rims, as on the east face of North Male. The western edges of the onter rims were lined with a belt of great patches of corals extending sometimes across the sandy rim flats of the faro.

The lagoon of the thind faro sonth of Irembadu Pass is divided into two by a transverse bar like the one of the northeast horn of Mulaku, figmed on the Admiralty Chart and mentioned by Mr. Gardiner. 'The three faros to the south are triangular with narrow rim flats. One of them is nearly two miles wide. The faro at the sonthwest angle of North Male is narrow, and on its eastern extremity a small island. fairly wooded, has been thrown up. On the eastern extremity of the faro to the west of Wilingili Island a couple of small islands bave been thrown up which are not indicated on the eharts.

On the west face of North Male north of Hembadu Pass, heaps of coral boulders oceur on the exposed points of the great faros which flank the northern part of the group to the south and to the north.

1 Mr. Gardiner's statement that in the Malrlive Atolls the bottom is perfectly smooth and that no new banks are springing up does not seem in accordance with the soundings of sueh groups as North Male and North Malosmadulu. In both these groups as well as in others are many sand banks and rings with varying depths, of from three to four feet on the rims to five or six fathoms. Nor is it the ease in the "jungle," a tract coveren with humlreds of heads within the twenty-fathom line in the central part of Nortl Malosmalulu. This as well as the general variation of the soundings sbows a far greater range in the depth of the bottom than one would infer from the remarks of $\mathrm{Ml}$. Gardiner. 
The outline of the reef flat to the south of Akirifuri is very striking. The lagoon face of the flat is formed by a series of great bays separated by points jutting out eastward two to three miles, in marked contrast to the rectilinear course of the western edge of the flat. This peculiar mode of growth of the corals shows that, if the bays they formed were closed across the east fuce, what might appear as a series of faros which had coalesced or become united had a very different origin, due to the rapid extension of coral spits at right angles to the western edge of the faro. Similar reef flats occur in other groups of the Maldives in Felidu, in Sonth Nilandu, in Kolumadulu, in Suvadiva and others to a less, extent. But nowhere are these cusps developed to such an extent as in this reef flat of the northern part of North Male.

The regetation on Akirifuri is scanty, and much of it is dying. The beaches of the island are steep, of very coarse yellow coral shingle with stretches of small coral boulders at the base of the beach. The vegetation of the islands of the faro to the north of Hembadu Pass is not vigorous; many of the trees and bushes on the outer belt of vegetation are dying or dead, having been more or less burier by the advancing sands blown into the islands from the beach (Pl. 19, fig. 1). Several of the sand-bars and banks marked on the chart as covered with low vegetation have disappeared, or the vegetation has been killed by the encroaching sands.

To the westward of our track on the way to our anchorage off Kagi we passed a narrow ereseent-shaped sand bank flanked with shingle. The vegetation on Kagi is most meagre, perhaps from its exposure to the full force of the northeast monsoon. This island is edged by coral sand beaches. On the southern face of Kagi corals are growing in abundance within the usual limits of depth.

The northern extremity of Male is open to the northwest, where it is flanked by a narrow reef flat for a distance of nearly five miles, similarly the northern faces of South Male and of Felidu are not well protecterl, and the greater part of the northeast face of Ari is open for a stretch of more than twelve miles. The northern face of North Malosmadulu is also open, as well as the northeast face of Ihavandiffułu and of Tiladumnati. 
On passing out of North Male through the eastem of the passes of the northern face of the group, we saw no boulder belt or heaps of shingle either on the sea faces or the pass fuces of the two northern faros of North Male.

The faro to the west of the pass is really a dimimutive irregularly rectangular atoll. It has a narrow entrance to the north, the western face of which is flanked by a small sand-bar. Within the lagoon are a few heads and diminutive faros (a faro within a faro); the greatest depth of the lagoon indicated on the chart is eight fathoms.

The absence of vegetation on the west face of North Male to the south of Hembadu Pass is a very marked feature, not only of that group, but also of most of the other groups of the Maldives. There are but few small islands on that face of the groups as compared to the number and size of the islands clothed with regetation found on the eastern faces of the Maldive groups. One need only compare the many islands on the east face of Ari, well clothed with vegetation, with the great faros of the west face, on which only here and there rises a diminutive island. It is on the eastern face of Ari also that the greater part of population is gathered, sheltered to a certain extent from the strength of the southwest monsoon. For the east face though exposed to the northeast monsoon, is, as it were, the lee side, if we can call that face by such a name, when we have a southwest and a northeast monsoon season. It merely indicates that the lee face is exposed to a monsoon blowing with less strength than on the western face.



The Stittan's Buggalow, at Anchor off Maie. 


\section{Gaha Faro.}

Plates 1,$3 ; 8$ u, figs. $6,8: 8 l$, fig. 11 .

Gaha Faro is eight miles in length by four in width, four to five times larger than many of the rings and faros of the Maldives. The greatest depth of its lagoon is twenty-two fathoms. Gafaru lsland is the only land on the rim of this atoll, with the exception of small sand banks, one on the southern face to the west of Gafarn and the others on the eastern spit of the notthern and the southern spit of the western entrances to Gaha Faro. Gafaru Island is edged by shingle beaches with a few patehes of coral boulders on the outer edge of its southern reef flat. The reef flat enclosing the lagoon of Gaha Faro is very narrow and shallow, the sea breaking over its surface and along the continuous outer line of the flat broken only by a narrow pass to the north and a similar one opening to the west. The continuous reef flat with its two passes gives Gaha Faro all the features of an atoll which it is difficult to distinguish from a gigantic faro. Had we seen it in the Pacifie it would pass as an atoll in no way differing from the many of its kind in the Ellice, Gilbert, or Marshall Islands. Yet in the Maldives, Gaha Faro and similar atolls are regarded as faros. Gaha Faro is separated from its adjoining cluster of faros on the northern point of North Male by a channel of not more than a mile and half in width, but with a depth of one liundred fathoms. ${ }^{1}$ While the faros of most groups are separated by narrower chamnels with a greatly varying depth, often not more than seven to eight fathoms, generally about twenty fathoms in the central part of the lagoon.

The freest possible circulation exists between the lagoon and the sea over the shallow reef flats of the atoll. Coral patches are scattered in abundance over the rim flats. At Gaha Faro as at many of the openings of faros and off the mouth of the passes leading into the larger enclosed basins, the water is often seen to be turbid, evidently carrying in suspension a considerable amount of silt stirred up by the action of the sea on the exposed face of the inner part of the lagoons, or of the islands and banks within an atoll, or from its shallow bottom.

1 See the depths of the ehannels separating North, Middle, and South Malosmadulu which range from one hundred to one hundred and fifty fathoms (Pls. $3 ; 8$, figs. 9, 10). 


\section{Goifurfehendu.}

Plates 1,$3 ; 8$ a, fig. $8 ; 8$ b. fig. 10;19, fig. 2; 20.

We skirted the eastern extremity of Goifurfehendu ${ }^{1}$ as well as the eastem half of its northern face; this gave us a fair idea of the structure of the atoll. It is elliptical, about ten miles in length and nearly five across its widest part. The atoll is surrounded by a continuous reef flat somewhat wider on the north and east sides than on the southern face; it has a single pass near the southwest horn. The deepest part of the lagoon is twentythree fathoms; the average depth is from eighteen to twenty fathoms. The central part of the atoll is clear of dangers. On the eastern part of the northern reef flat of Goifurfehendn are three large islands of which the island of Goidu, at the very eastern point of the atoll and on the widest part of the reef flat, is the largest. The southern extremity of Goidu Island appears to be wasting away, a small adjoining island marked on the chart has disappeared. A narrow sand beach extends along the central part of Goidu parallel with the outer belt of vegetation close to the water's edge. At the northeast point of Goidu the upper part of a steep shingle beach has been driven far into the outer belt of vegetation. On the northern face of Goidu Island the vegetation is not flomrishing, and it reaches the water's edge. The eastern face of Goidn Island is steep to close to the edge of the outer insignificant reef flat; in places the surf beats directly upon the beach. The projections of the northern face of Goidu form a large rectangular bay; the island seems to be increasing in size towards the west.

The northeastern part of Goifurfehendu atoll is exposed to the full force of the northeast monsoon. On the outer edge of the reef flat are numerous great patches of corals, showing that they grow abundantly on the northern slope of the atoll. On Fehendu, the next island to the west on the wide northern reef flat, the vegetation is fine with many clusters of large trees. Opposite Fehendu the onter reef flat is wide, the island thus appears to be placed well in the middle of it. Inafuri is the westernmost island of Goifurfehendu.

Gardiner" notes the "more purely oceanic conditions of this atoll than any other of the more perfect atolls of small size except Addu" as well as

1 On Plates 1 and 3 Goifufehendu should be Goifurfehendu.

2 Loc. cit., p. $37 \%$. 
its slight protection by the east hom of South Malosmadulu; he recognizes the former recent conneetion of Fehendu and Furudu which were probably formed by the piling up of sand on the flats fringing the lagoon. According to him, "the lagoon is increasing in size at the expense of its encircling reef," the outer contour of his figure being the same as that on the Adniralty Chart, but the reef flat is charted much broader than in Mr. Gardiner's figures. ${ }^{1}$ Furudu Island is wasting away.2

\section{Karidu.}

Plates 1,$8 ; 88$, fig. $11 ;: 1$.

Karidu is a small elliptical atoll about two miles in greatest diameter, nearly halfway between Gaha Faro and Fadiffolu. It rises abruptly in a channel nearly thirty miles aeross, from a depth of about three luundred fathoms. It would be called a faro were it placed on the face or the central area of one of the larger of the Maldive groups. A wide curved islind, following the line of the reef flat, oceupies the greater part of its southern rim, to the west of which rises a small islet. The reef flats to the north and south are shallow and enclose a comparatively shallow lagoon. The point of the south face of the east end of Karidu is covered with coarse shingle; that part of the island is steep to ; the reef flat gradually widens to the west; along the centre of the south face of Karidu rises a steep shingle beach which extends to the base of the outer belt of low bushes. A few large forest trees grow in the centre of the island, much of the vegetation of Karidn is dead; many of the bushes formerly above the beaches now stand in the water on the edge of the reef flat.

At the western extremity of Karidu the central shingle beach has gradually passed into a coral sand beach which extends in an ill-defined sand spit along the narrow reef flats of the northem face of Karidu. On the reef flats corals abound; huge patches extend from the outer rim of the atoll towards the lagoon. On the shallow northern reef flat the breakers due to the northeast monsoon form an almost continuous line.

$$
1 \text { Loc. cit., fig. 90, p. } 37 i_{\text {. }}^{2} \text { Loc. cit., fig. 91, 13. } 378 .
$$


The lagoon has gradually filled; it now consists only of a large bottleshaped pool towards the eastern end of the atoll, probably with four or five fathoms of water, judging by its color.

A narrow opening leads into the lagoon; the pass is indicated by a heap of boulders on the western face and a small sand-bar on the eastem. The island of Karidu as it exists to-day does not, owing to the wasting away of the western extremity, occupy as large a proportion of the area of the reef flats as is indicated on Noresby's chart (1836).

\section{Malosmadulu Plateau.}

Plates 1, 3; 8 a, fig. 5 ; 8 b, figs. 9,$10 ; 8 r$, fig. $28 ; 22-80 ; 31, f i g .1$.

South, Middle, and North Malosmadulu resemble Male and Ari as far as the location of the faros and of the islands on the outer faces of the Malosmadulu platenus is concerned (Pl. 3). Their western face is flanked by large faros, some of them over five miles in length, separated by wide and deep passes. In fact, the faros are atolls of considerable size with as great a variety in size and shape as exists among widely separated atolls in other coral reef regions. Compare, for instance, such faros as Maduni Faro, Ekuru Faro, Ma Faro, Defili Faro, Mawa Faro, which are lagoons surromded by wide reef flats, with faros having one or two islands on the rims, such as Kandu Gandu, Bodı Faro, Femfuri Faro and Turadu, ${ }^{1}$ having all the features of small independent atolls with a minimum of land masses on the reef flats. The former really belong to the same category as the atolls, though no islands or islets have as yet been thrown up on the rim flats.

The east face of North Malosmarlulu and the southenst face of South Malosmadulu are flanked by a few faros and a number of islands running at right angles to the trend of the east face of Malosmadulu; they are separated by wide and deep passes, some of them over three miles in width.

North Malosmadulu bears a elose resemblance to Ari; like it, it is flanked on the west by large faros and on the east by numerous islands, all steep

1 Turadu, according to Gardiner, has become modified into a linear reef Aat; loc. cit., p. 380, fig. 94. 
to, well wooded, and separated by deep passes. It has, like Ari, many faros and rings within the enclosed basin of the group; the central basin, inside the twenty-fathom line, is erowded with a mass of faros, islands, banks, bars, rings, and heads, which constitute a perfect labyrinth and render the navigation of that part of North Malosmaduln impracticable.

The islands near our track, both in South, Middle, and North Malosmadulu, seem to have been built on one pattern. At first they are small banks without vegetation thrown up on the rim of a small flat or faro. The bank gradually inereases in size, oceupying a larger part of the rim. The lagoon then becomes silted up, and eventually the sand bank occupies the greater part of the area of the faro, becoming elothed with vegetation as it inereases in size, and finally passing into a wooded island, steep to or with a narrow reef tlat, as in Wadu, Medu, and other islands in the southern part of North Malosmadulu, or of Karidu, Mararrekelhu, and Anglenufuri in Middle Malosmaduiu and Kendu, Hurudu, and others on the northern and southern faces of South Malosmadulu.

The deepest somnding indicated in the South Malosmaduln group is thirtyeight fathoms; the greater number of the soundings are between twenty-five and thirty fathoms. In North Malosmaduln thirty-one fathoms is the deepest sounding indicated on the chart, and ontside of the area enclosed by the twenty-fathom line the average of the soundings is between twenty and twenty-five fathoms. In Middle Malosmadulu the deepest sounding is twenty-seven fathoms, the soumdings average abont twenty fathoms.

It is interesting to compare the position of the atoll of Goifurfehendn (Pls. I, 3), separated from South Malosmartulu by a channel nearly six miles in width and a greatest depth of three lumdred and two fathoms, with that of the typical Maldivian group of South Malosmaduh, separated from Niddle Malosmadulu by a channel varying in width from one to two miles with a greatest depth of one hundred and forty fathoms, or with that of Middle Malosmadulu, divided from North Malosmadulu by a channel of nearly three miles in width, and a greatest depth of one hundred and thirty-five fathoms. Contrast this with Femfuri Faro, which is north of the southwest horn of North Malosmadulu and separated from the faros to the north and to the south by chamnels, the one about a mile and 
a quarter wide, with a greatest depth of twenty-seven fathoms, the other nearly two miles wide, with a depth varying from twenty-two to twenty-six fathoms.

The relation which these faros or small atolls hold to Middle Malosmadulu are similar to those of Goifurfehendu to South Malosmadulu, or of South Malosmadulu to Middle and to North Malosmadulu, or of Galıa Faro to North Male. The distances and depths separating the atolls are merely questions of quantity.

The faros, or atolls, or lagoon reefs, built up on the summits of the plateaus rising from various depths, are all atolls, though they may differ greatly in size and shape, they all represent variations similar in kind; there is no fundamental difference between them. The lagoons of the largest Maldivian atolls, like Addu, Gaha Faro, Goifurfehendu, Makunudu, Watarn, are but little deeper than the lagoons of smaller faros like those I have just mentioned, or of the many others seattered over the various groups of the platean of the Maldives.

We cannot distinguish these faros from atolls, whether isolated or forming a part of an extensive chain, or occupying a portion of the face of the Maldivian platean, or scattered within the basins enclosed by these chains. The faros and atolls have the same characteristic features, and nowhere is this more prominently brought out than in the group of islands forming the so-called Tiladummati and Miladummadulı atolls (Pls. 2, 3).

Other eases of isolated faros and of atolls are the Powell Islands, about eight miles west of Miladummadulu; Makmudu, nearly ten miles off the west coast of the same group with a depth of nearly eight hundred fathoms in the centre of the dividing channel; Ihavandiffulu, separated from the norther'n face of Tiladnmmati by a channel of nearly four miles in width, with a greatest depth of two hundred and fifty-one fathoms. The large faros at the northern extremity of Tiladummati, separated as they are by wide and deep channels, show the impossibility of distinguishing faros from atolls.

An extreme case, perhaps, is that of Karidu (Pl. 3), distant about sixteen miles from Fadiffolu and twelve from Gaha Faro, with greatest depths in the channels of three hundred and seventy-two and two hundred and 
fifty-eight fathoms. This small faro, for it would be considered small even if it formed a part of one of larger groups, differs in no way from a large number of the characteristic faros of the Maldives. But Karidu has all the characters of a small Pacific atoll; it is isolated, separated by wide channels from the nearest groups, and instead of rising, as do other Maldivian faros, from a broad bank with an average depth of from twenty to thirty-five fathoms, it rises as the summit of a diminutive mound, surrounded by depths of nearly three hundred fathoms. Side by side identical structures exist which have been built up in one case from the minimum depths of twenty to thirty-five fathoms; and in the other, upon summits rising from depths of over three hundred fathoms; and certainly the former do not owe their origin to subsidence. Otherwise Karidu has been formed by the subsidence of a plateau to a depth of nearly 300 fathoms, Gaha Faro to 100, Makumudu to nearly 800 , Ibavandiffulu to 250, Middle Malosmadulu to 100 or 150, Rasdu to 120, Wataru to 200, the hosts of small atolls on the outer faces of the Maldivian groups and of the rings and faros within these groups to twenty or thirty-five fathoms (Pl. 1). The different depths to which these atolls have sunk all occur within the same district, and postulate an irregularity in the rate of subsidence of different and adjoining tracts of this area which it is difficult to imagine, and for which a very slow and regular rate of subsidence has always been demanded. We can far more readily understand the existing conditions as due to the different levels to which the irregular bottom of the great Maldivian plateau has been elevated. In fact, the topography of this wide submarine ridge is neither more nor less varied than that of a mountain plateau.

\section{South Malosmadulu.}

Plates 1, 3; 8b, fig. $10 ; 8 r$, fig. 28; 22-2S; 29, fig. 2.

South Malosmadulu (Pl. 3) is irregularly triangular, its apex facing east; the greater part of the enclosed basin of the group, in a belt parallel to the south face is filled with large faros, many of them more than three miles 
in length. In addition a number of small banks, islands, and islets or faros are clustered in the northeastern area of the group.

The slope of the eastern face of South Malosmadulu is, according to the soundings (Pl. 1), very gradual, far more than that of many of the other groups. The one hundred-fathom line is at a greater distance from the edge of the onter row of islands, faros, and reef flats. This is not the case with the western face of either North or South Malosmadulu (Pl. 1).

Some of the islands in the northeastern area of South Malosmadulu are of considerable size, and many of them are well wooded. An island to the westwird of Mabaru is specially noted for its fine trees. The eastern edge of the reef flat to the south of Mabaru is covered with patches of corals, and fringed with stretches of boulders and heaps of shingle.

The extremities of Mabaru (Pl. 22, fig. 2), exposed to the action of the northeast monsoon, are wasting away on the sea face, as are the islands to the south, many cocoanut palms lying prostrate at the base of the beaches.

The vegetation on the islands of the east face of North and South Malosmadulu is far more flourishing than that of Fadiffolu, probably becanse it is not exposed to the force of the southwest monsoon. On the southeast face of South Malosmadulu both the monsoons blow along the trend of the face, so no heavy swell or sea pounds upon the beaches of that part of South Malosmadulu.

The deep wide passes separating the islands of the southeast face of South Malosmadulu give the impression that the islands are scattered. irregularly over an indefinite sea space, and not that they are part of the land rim of an atoll (Pl. 23).

Aidu Island (Pl. 22, fig. 1) is steep to, with deep wide passes on each side. It is surrounded on the sea face by steep, coarse shingle beaches, passing into colal sand beaches towards the west; it is covered with fine vegetation. To the south of Mabaru, between it and Aidu, a large, irregularly shaped faro, Wandu Faro, fully three miles in length, extends westward. Two islands are found on its western rim. Another large faro, Humi Faro, lies to the sonth of Aidu, with islands at the eastem and western extremities; its lagoon has a greatest depth of six fathoms. The islands 
are flanked by steep coral sand beaches; the outer edge of the rim flat is covered with large patches of thriving corals. On the sea face of Kumfinadu are ontlying patches of boulders and angular reef rock, honeycombed, pitted, and undercut, similar to patches found elsewhere in the Maldives, indicative of a slight former elevation.

Gardiner ${ }^{1}$ says most of the reefs to south and east show traces of a broad line of elevated reef rock on the sea face, with extensions along the faces of the passages which are still going on. He also states that the bottom of South Malos is everywhere hard sand, and singularly barren of organic life, ${ }^{2}$ and that dredging points to a general growth of corals on the outer edge, though it may only be in isolated patches.

After skirting the east face of South Malosmadulu we entered it through the pass east of Hitadn; on either side of the island are Olugeri and Maduwari, both steep to. The vegetation of Olugeri as seen from the pass appears to be quite luxuriant. The west face of Maduwari (Pl. 25) is flanked with a steep beach of coarse coral shingle, so steep as to form an almost vertical wall along part of the island. The shingle has been driven in anng the base of the trees and between the clumps of bushes well back from the beach towards the interior of the island. The coarse coral shingle surrounds the sea face of the island and the greater part of the eastern face along the pass. On the lagoon side of the island it is flanked by steep coral sand beaches. On the steep to sea face slope of Maduwari corals are very luxuriant down to a depth of twelve fathoms, where they become small, and are separated by belts and lanes and patches of sand until they are completely choked and disappear in depths of sixteen to twenty fathoms. ${ }^{3}$

The southwestern hom of South Malosmadulu is formed, according to the chart, by Turadu, a large faro about four miles in length. The main part of the faro has at the northeast angle a regular entrance like that of any atoll of its size, is bounded on the southwestern and southeastern faces by a wide reef flat, on which are two islands, and which forms the southern rim of an elongated lagoon with from three to six fathoms in

\footnotetext{
1 Loc. cit., pp. 384, $385 . \quad 2$ Loc. cit., p. 381.

${ }^{3}$ See Gardiner's account of this island, loc. cit., p. 164, fig. 30, and p. 384.
} 
depth. The northern rim, according to the chart, is a very irregular narrow belt awash here and there with a secondary lagoon at the northern spit of this rim.

The clianges at Turadı from the conditions marked on the Admiralty Chart are, as stated by Gardiner, very marked ${ }^{1}$ and were also noted by us at the time we passed by Dunikolu and anchored near Embudu, but I cannot agree with Mr. Gardiner that the extensive changes observed there are wholly due to solution. ${ }^{2}$ The cyclone by which the island was struck would account for the movement of a great mass of sand such as perhaps formed the northem rim of Turadu in 1836 .



Boats from Turadu.

To the northeast of Turadu rises Dunikolu, a small island with a low coral sand beach and covered with a scanty vegetation. Near our anchorage stretched another, smaller faro (Velengeli), a little over a mile in diameter, with an island on its western rim having somewhat the character of an outer island. The wide rim of this faro cnclosed a shallow lagoon the great part of which had been filled up.

The little island of Embudn (Pls. 26, 27) to the north of our anchorage is covered by a scanty vegetation; it is surrounded by a narrow reef flat and is flanked by steep almost vertical beaches of fine coral sand. At their

1 Loc. cit., fig. 94, p. 380.

2 Gardiner states (loc. cit, p. 386) that in the northeast part of South Malos there seemed to be little change within the lagoon. 
base there are patches of beach rock. The deeper slopes are covered with a magnificent growth of corals extending down to a depth of from twelve to fourteen fathoms, where the corals become patchy and gradually disappear in from eighteen to twenty fathoms in a sandy bottom. The beaches are covered with windrows of small masses of pumice varying from the size of hazel-muts to that of one's fist. Many cuttle-fish bones and Spirula shells have also been blown up above high-water mark.

On the onter edge of the rim of Mutalifoori, projecting here and there high above the outer rim, extends a belt of coral bonlders. 'The little island on the western rim is bordered with low sand beaches; the rim of the faro is comparatively wide, enclosing a small lagoon. The onter belt of the rim flat is thickly covered with great patches of corals which, as off Embudu, seem to be very flourishing on the slopes of the lagoon reef. 'To the east of our track on the way north about a mile and a half from Mutalifoori, we passed a large elliptical ring with from three to six fathoms in depth and more than two miles in length. On the western side of our track nearly opposite, another faro was passed, fringed on the outer edge of the east face of the rim with irlegular patches of boulders.

We passed close to the eastem extremity of Wakaru, a small island on the eastern point of a large ring with from three to four fathoms in the lagoon. On the east face of Wakaru a steep beach has been thrown high up in the outer belt of bushes. At the enstern point the base of the beach is flanked by stretches of beach rock.

At both Embudu and Wakaru the outer beaches lave been thrown up considerably higher than the general level of the central part of the island. This forms a rim to an inner sink or dish from twelve to eighteen inches or more lowel than the summit of the beach. This apparent dishing is quite common among the small central islands of the Maldives, and when it occurs on the rim of an island which is steep to, the inner sink might readily be mistaken for the bottom of a dry lagoon, or for an atoll the lagoon of which had been slightly elevated above the general level of the surrounding reef flat.

As we passed Megeli we noticed a small, low sand-bar on the sonthern fice of the faro to the west of it, which is not indicated on the chart. 
Megeli Island is crescent-shaped. It occupies the castem part of the rim flat of a faro of which the lagoon has been completely filler. The small islet on the east face of Muduwari (Pl. 28, fig. 2) is covered with low bushes.

From Muduwari north towards Kendu and the islands which form the northern boundary of South Malosmaduln the atoll is clear. Kendu (Pl. 29, fig. 2), like the other islands to the eastward, is steep to, with steep and high sand beaches, much higher than any sand beaches we have seen in the central groups of the Maldives. The western point of Kendu, which is exposed to quite a reach of the sonthwest monsoon, is covered with coral boulders. The islands and faros of the north face of South Malosmadulu are divided by deep and wide passes.

At Kiadu (Pl. 28, fig. 1) the apparent depression due to the height of the enclosing beaches is very marked. Kiadufuri is a beautiful elliptical ring with wide reef flats enclosing a lagoon with from five to six fathoms in depth, and an extensive sand bank on the southern face; this is not indicated on the charts of 1836. At Hanikandu Faro, which forms the northwestern angle of South Malosmadulu, the enclosed lagoon is said to be twenty fathoms in depth.

\section{Middle Malosmadulu.}

Plutes 1, 3; 86, figs. 9, 10; 99, fig. 1 .

The large triangular bank wedged in between South and North Malosmadulu may be called Middle Malosmadulu; it is separated from them by deep channels of from two to three miles in width, and with depths varying from one hundred and ten to one hundred and forty fathoms in the axis of the chinnels. The enclosed area of Middle Malosmaduln is free from patches or faros. Its faces are bounded by comparatively few islands and large faros, separated by wide and deep passages. The greatest depth of this bank is twenty-six fathoms, with a general average of about twenty fathoms.

We examined some of the islands and faros of the southern and northwestern faces. Karidn Island is steep to, like Kendu and the islands on 
the northem face of South Malosmadulu, and flanked by high and steep sand beaches. Kari Faro (Pl. 29, fig. 1), a large faro to the west of Karidu, has at the western extremity a broad crescent-shaped reef flat with steep sand beaches, and a narrow elliptical lagroon of a dark blue color, from three to four fithoms in depth; the extremity of its castern rim is occupied by a small sand-bar topped by a clump of vegetation.

Many of the islands of both North, Middle, and South Malosmadulu appear as slightly dished on account of the height to which the summits of the encireling beaches have been thrown up. Mararrekellu, an island on the northwestern face, is, like Karidu, steep to, with steep coral sand beaches, and covered by a scanty vegetation. Anghenufuri, marked as a small lagoon flat to the east of Mararrekellu, since 1836 lias become entirely filled. It is now an islet on the eastern flank of a small reef flat. Many of the smaller islands of this part of Middle Malosmadulu seem to be old faros of which the lagoons have been silted up, and subsequently the islands lave eneroached on the reef flats so as to oceupy the whole of the former area of the faro and the surrounding reef flats. So that former diminutive circular barricr reefs have gradually been changed to fringing reefs, as Karidu has in part.

\section{North Malosmadulu.}

Plates 1, \&: 8 at, fig. $5: 8 b$, fig. $9 ; 8$ c, fig. $26: 30: 31$, fig. 1 .

The northern extremity of North Malosmadulu is open like that of Ari (Pl. 3); on the northern part of the eastern and western faces the faros and islands are more distant and separated by wider and deeper passes than in the southem half of the group. Comparatively few faros, rings, and islands oceur in the interior of the northern half of North Malosmadulu, and in a belt parallel to the southern part of the east face. But in the central part of North Malosmadulu, towards the western face, the twentyfathom line encloses a large area with innumerable islands, islets, sand-bars, faros, and coral heads. The southern part of this area is flanked by a belt of a few more widely separated large islands and faros. The islands on the east face of North Malosmadulu are large (as Maldive Islands go), and 
are separated by wide and deep passes, gradually becoming wider towards the northern part of North Malosmaduln. Some of the northern passes are over two miles in width.

The sonthwesteru hom of North Malosmaduln is formed by Mamanaga (Pl. 30, fig. 1), a large triangular faro the base of which is nearly five miles. It has a wide rim on the western face, and a lagoon with from five to six fathoms in depth. A small sand bank has been thrown up on the northwest horn of the faro. On the southern face to the east of Mamanaga are two smaller faros (Velengeli and Furuwari), somewhit more than a mile in length, with very wide enstern rims, a small lagoon towards the western extremity, and each with a small bank on the eastern horn of the faros. Velengeli is flanked with coarse shingle. The sonthwestern part of North Malosmadulu is quite clear of faros, banks, rings, and islands, so that when entering the group through the pass to the east of Mamanaga, we opened a great stretch of clear water to the northeast as if we had passed out into the open sea. To the north of the sonthwestern horn and separated from it by a channel fully a mile in width lies Femfuri Faro, a long triangular faro fully three and a half miles in length, with the apex to the east and the eastern horn occupied by a small island. Its northern and southern rims are narrow, they pass griulually into a wide western reef flat.

Tura is a small island facing the wide pass on the west face of North Malomadulu between Femfuri Faro and Ma Faro; it is steep to, bounded by a high steep sand beach; near the southem point extends a stretch of coarse shingle beach, and on the westerm spit of the island a belt of small coral boulders. After passing Tura one sees to the northward rising upon the horizon the islands occupying the inmer belt of North Malosmaduln to the south of the twenty-fathom curve.

Maregiri ${ }^{1}$ Island lies south of Bodu Faro, the large faro which occupies the western horn of North Malosmadulu. On the southwest it is flanked by steep sand beaches from ten to twelve feet high, with stretches of coarse shingle driven towards the interior among the bushes and between the base of the trees beyoud that belt. A narrow boulder belt flanks the base of the beaches. At the western point there is a narrow reef flat 
covered with beach rock, and a patch of reef rock honeycombed and weatleled, pitted and undercut; elsewhere the island is steep to. Facing the pass to the south, the beach is composed of coarse shingle and reaches of sand with large boulders at the east point. Unfortunately we could not land and examine the ligh dunes on the island mentioned by Mr. Gardiner.'

Mr. Gardiner Iras made a careful comparison of Moresby's Chart: of a stretch of the westem face of North Mahlos, extending from Kukuludi Faro to Marluni Faro, with sketches of his own. ${ }^{2}$ He finds well-marked velus in Dina Faro and Ma Faro; none are on Moresby's Chart. ${ }^{3}$ At Telin Faro and Bodu Faro, the broad eastern rims of the velu shown by Moresby have disappeared and they have become connected with the general lagoon. The faros to the north do not indicate any special change. Mr. Gardiner considers the enlargement of the velus as due to the solvent action of sea water. Similar differences on the chart between Turadu and Dunikolu he attributes to the same cause. When, as is often the case, the rims of the velus are merely sand, their demolition and the increase of size of the enclosed velus is not necessarily due to solution. The filling up a velu would result in a reef flat. A study of the northeastern point of Tiladummadulu indicates an increase of the land areas of the faros.

I fully agree with Mr. Gardiner's ${ }^{*}$ view that every large reef on the bank has grown up by itself. It does not follow, however, from the changes he has observed, that North Malos is approaching the condition of a perfect atoll. We can trace the passage of such rims composed of atolls, into long linear reefs only in very limited areas.

IVe passed out of North Malosmadulu through the pass west of Tura, and entered again by Maregiri Island (Pl. 30, fig. 2; 31, fig. 1). Steaming in a southeasterly direction, we crossed the corner of the area bounded by the twenty-fathom curve, and obtained an idea of the character of the "jungle of reefs," ${ }_{5}$ crowded as it is with banks, rings, coral heads, faros, flats, and islands and.islets. The first islet we came upon was a small sand islet with a clump of bushes in the centre, with steep coral sand beaches and

1 Loc. cit., p. 166.

a Though the original charts might have indicated such a velu from the position of the coral rocks on the outer edges on both these faros.

4 Loc. cit., p. 171.

5 Gardiner, loc. cit., p. 167. 
a narrow flat, the outer edge of which is indicated by a line of small coral boulders.

The island of Fusmundu fills the eastern rim of a well-defined faro about a mile in length. It is flanked by high steep coral sand beaches. The outer northwestern edge of the rim of the faro is lined with small coral boulders. From the great height of the beaches enclosing the central part of the island it presents a dished appenrance. A few fine large trees rise in the central part of the island, but many bushes and smaller trees of the outer belt have been killed by the spreading sand or are in a dying condition from the encroachment of the sea.

To the enstward we came upon Muduwari, a small nearly circular island occupying the greater part of the flat upon which it has loeen thrown up. The coral sand beaches are high and steep, the summit of the beach rising far above the central part of the island. The island seems to be wasting away; a small islet covered with a little vegetation once a part of the main islet now stands isolated upon the reef flat near the eastem point of the island.

On the central part of the north side of Hoholundı Island sand has been blown from the summit of the high sand beaches well towards the interior, and has overwhelmed many of the bushes of the outer belt and buried the base of a number of the larger trees. Hoholund I Island, like the islands we have just described, occupies the eastern rim of the flat upon which it has developed. Hoholundu Faro is nearly a mile and a half in length.

At no time during our cruise through the Maldives did we pass through a region containing so many banks, rings, faros, heads, islands, and islets as on our way from Maregiri to Medu, when we cut across the only part of the labyrinth of North Malosmadulu which seemed to promise a . clear passage. The various islands, the different kinds of flats, bars, rings, and faros in the interior of North Malosmadulu, differ in no way from those on the outer rim of the so-called atoll of North Malosmadulu. They have all been formed in the same way both in the interior of the group and on the outer belt. The outer faros and islands being more exposed to the modifying influences due to currents and the action of the winds, have developed more freely and with greater rapidity. Yet some of the islands 
and faros of the interior compare favorably in size, in the extent of the boulder belt, the height and steepness of the sand beaches, the widtl of the rims and reef flats with similar structures on the outer belt of the group. This is specially the case when the islands in the interior basin are in such a position as to face a long reach either of the northeast or southwest monsoon, and are thus placed in conditions more similar to those of islands and faros on the exterior faces of the groups.

Medu, one of the most important islands of North Malosmadulu, is steep to ; it is surrounded by a high steep coral sand beach with many large trees in the interior basin of the island formed by the high beaches, the summit of which rises from four to six feet above the inner flat. The upper part of the bcach we found covered with windrows of masses of pumice. On the wide sea slope flat corals flourish in great abundance at from six to seven fathoms of depth, where the slope drops rapidly, and corals become less numerous; at a depth of abont twelve fathoms they disappear very rapidly as they become separated by lanes and patches of sand and overwhelmed by sand-bars. The regetation of the central part of the island is made up of numerous large trees of Breadfruit, Pandanus, Banyans, and other forest trees surrounded by a thick onter belt of low bushes and trees; many of the bushes belong to genera found on the beaches of Pacific atolls. The summit of parts of the outer coral sand beach of Medu is from fourteen to fifteen feet high; the wide path leading across the island drops from three to four feet towards the interior after passing the flat summit of the beach.

The islands we passed to the north of Medu - Digeli, Tahwahtah, Roongelly, as well as others we saw in the distance - all rise upon flats of considerable size; like Medu, they are surrounded by high and steep coral sand beaches, but their vegetation is less flourishing, consisting mainly of low buslies and shrubs.

We examined the islands on the east face of North Malosmadulu from Kotafuri north to Kuda Kura and near Anguretin; those further sonth and north, which we did not visit, present, according to the chart, no different features from the former. The islands to the north of Kotafuri all have long reef spits extending to the westwart. The beaches of Kotafuri are 
wasting, clumps of bushes and trees standing isolated on the surrounding reef flats. A coarse shingle beach faces the south side of Wandu; towards the east and the west the coral sand beach is ligh and steep. There are no faros on the central part of the east face of North Malosmadulu and only one on the northern and one on the southern extremity of the face; the other islands are generally steep to with narrow reef flats. 'The vegetation of these islands is not prominently developed, though occasionally a fine clump of trees rises above the low onter belt of bushes and smaller trees. The vegetation of Wandu is better developer than that of either Rasmadu or Kuda Kura, the southem beach of which, like that of Kotafuri, is wasting away. The vegetation on Makara is perhaps finer than that of any other island on the east face of North Malosinadulu; it consists mainly of extensive clumps of large trees. The island is surrounded by coral sand beaches with little or no shingle; while on the other islands on the east face of the group the eastern extremities are flanked with shingle.

On Inamadu very coarse shingle extends from the eastern point halfway towards the western extremity on the southern face of the island. where it suddenly changes to fine coral sand. The beaches of the east face of North Malosmaduln are less steep than those of the islands in the interior of the group or on the west face of North Malosmadulu. The islands to the north of Inamadu have the same general character; the vegetation is fairly developed; they are all steep to on the southern and northern faces, with spits or reef flats extending to the westward, but steepest at the eastern points, where the reef flats are narrow and the islands are edged with steep shingle and boulder beaches. On the north faces the shingle and coral sand beaches are distributed much as on the southern faces of the islands.

Kuda Kura is a long narrow island with scanty vegetation; it is nearly in the centre of an extensive reef flat projecting to the westward. A somewhat smaller reef flat, edged by a belt of small coral boulders, forms the enstem point of the island, which terminates in a steep shingle beach. An exceedingly coarse shingle beach has been thrown up on the east face of Rasmadu, as well as on the northeastem horn of Inamadu, where the shingle has been forced inland between the trees over the summit of 
the beach. The narrow reef flats of the eastern faces of these islands are all edged by a belt of small boulders. The eastern spits of the islands to the south of Wandu nearly all indicate a certain amount of wasting away.

Anguretin and the adjoining islands of the northern extremity of the east face of North Malosmadulu are noted for their fine vegetation. Like the southern islands of the east face, they are on the whole steep to, especially on the sea face, with comparatively small reef flats. The islands are surrounded by steep, coarse shingle beaches on the sea face, passing into fine coral sand beaches towards the west. Both the shingle and sand are driven far in between the base of the large trees across the outer belt of bushes and low trees. All the islands of the east face appear slightly dished from the heights to which the outer summits of the beaches rise above the enclosed interior area of the island.

The deepest sounding in North Malosmaduln is thirty-one fathoms. The average of the soundings in the gromp to the north of the "wilderness," as well as to the sonth and west, is between twenty-fom and thirty fathoms. In Middle Malosmaduh the depths vary between seventeen and twenty-four fathoms. In Southern Malosmadulu the greatest depth indicated on the chart is thirty-five fathoms. The interior of this group is somewhat deeper than either North or Middle Malosmadulu, a great many somndings indicating a depth greater than thirty fathoms.

Off the northern extremity of North Malosmaduln, separated by a channel of three miles in width, are Powell's Islands, Etingili and Alifuri, at the two extremities of a narrow isolated bank about three miles in length. We dil not visit them. They stand to North Malosmadulu in much the same relation as do other atolls or lagoon reefs and islands such as Wataru Reef, Rasdu and Toddu Atolls, to Ari and Mulaku.

\section{Makunudu.}

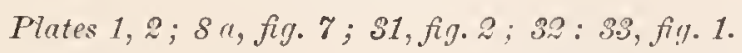

We examined the northeastern part of Makunudu (Pl. 2), an atoll about nine miles west of Miladummadulu. It is about fifteen miles long, run. ning nearly north and south, and quite narrow, - not more than three 
miles wide. The northern face of the atoll is angular; its northeastern horn is well defined by Makunudu Island (Pl. 31, fig. 2); the rounded southern face of the atoll forms its southern born.

The lagoon of Makunudu is of considerable depth; seventeen fathoms are indicated on the chart. As seen from the outer reef flat, it appears to be thickly studded with bars, flats, and heads. There are two shallow passes on the east face of the atoll.

Immediately south of Makunudu Island lies the small island of Fengbu Hurah, in the centre of the east face the islet of Faro Doru (Pl. 33, fig. 1), covered with tall bushes, and on the northwestern horn a cluster of diminutive islets covered with bushes. The reef flat which connects Fengbu Hurah with Makunudu is flanked along its onter edge by conrse shingle, and the islands themselves really constitute one island, connected as they are by long sand spits, forming a more or less continuous coral sancl beach between them.

On the chart the outer reef flat of Makunudn is characterized as a "dry reef." As far as we examined it, and from what we could see looking across the atoll, the outer edgre of the narrow reef flat is edged by a low wall of angular coral boulders and heaps of eoarse shingle (Pl. 32); the boulder wall is undercut and greatly weathered. This belt and the shingle heaps form a dry rcef, as it were; it extended as far as wc could trace it, south to Faro Doru, on the northern face of Makumudu, and on the western face, judging from what we could see looking across the atoll. We examined the wall of weathered coral boulder off the east face of Makunudu, where it is better developed than at any other point of the atoll. It seemed to be made up of coral refef rock and coral boulders cemented together, undercut and greatly weathered; rising above the general level of the surrounding reef flats, they indicate a slight former elevation at that point. We observed at many places in the Maldives patches of similar reef rock, all pointing to a slight elevation at many and widely scattered localities in the Maldives. The narrow reef flat on the east face of Makunndu Island widens out at its northern face where the low wall of coral boulders is broken through to fornı a shallow boat passage leading into a small secondary lagoon of moderate depth which connects with the 
larger lagoon round the northern point of the island. The coral sand beaches of the northern part of Makunudu Island are high and steep, the beaches of the sontheastern face are flanked at the base with reaches of beach rock. Occasionally a larger coral boulder rises on the outer edge of the reef flat above the general ontline of the low wall.

On the onter edge of the reef flat of the northeastern horn of the atoll (Pl. 32), thrown up along a part of the low boulder wall, lies a snall island covered with a clump of bushes. The existence of this islet in its present position, identical with that marked on the chart, seems to indicate that no great changes have taken place in the topography of the northern part of Makunudu, in spite of the existence of the fringing coral boulder wall which has been in part elevated and in part probably thrown up on the east face by the northeast monsoon and on the west face by the southwest monsoon.

\section{Fadiffolu.}

Plates 1, $3^{\circ}: 8$ u, fig. 4: 8l, fig. 11: 8c, fig. 28; 33, fig. 2; 34, fig. 1 .

The southeastern face of Fadiffolu (PI. 3) is bounded by a reef flat, the greater part of which is nearly two miles wide. Aligan, a small ishand, occupies the southwestern horn of the group; a belt of boulders edges its southern point; the northern and western faces of the island are flanked by sand beaches. The vegetation of Aligau (Pl. 33, fig. 2) is not flourishing; much of it is in a dying condition. A belt of coral boulders and heaps of shingle extend along the outer edge of the eastern reef flat. There are comparatively few islands on the eastem reef flat, though one of them, Difuri, ${ }^{1}$ is over three miles long.

1 Loc. cit., fig. 103, p. 397, shows the changes observed by Mr. Gardiner in Moresby's Chart of Fadiffolu. It seems to me rather hazardous to base upon native reeords of the former cxistence of islets and shoals in the centre of the lagoon any conclusions as to the breaking np of reefs and shoals in the enelosed parts of Fadiffolu. With such deep and wirle openings as cxist on the southwest face of Fadiffolu and from the existenee of the broad reef thats on the eastern faees over whieh a greal amount of water ineessantly passes, it ean hardly be called "one of the more circumscribed atolls." It is difficult to riconcile Mr. Gardiner's statement that "the lagoon is increasing on all sirles at the expense of the encireling reefs" (p. 396) with the impression "that everywhere the rim reefs were growing together to form a single enclosing band."

The position of Inawari (loc. cit., p. 399) "too far west on its reef "may be dne to its eastern migration, as is the ease of many other sandy islands whieh inerease cither to the east or west or migrate bodily. 
Were it not for the existence of velus, ${ }^{1}$ the appearance of the reef flats of the southeast fice of Fadiffolu is quite that of some of the reef flats of the Pacific atolls, with their double row of islands.

Fadiffolu is irregularly rectangular in shape with rounded corners. The northeastern and southwestern faces are concave, the others convex. It is nineteen miles in length and about twelve miles in width. On the sonthwestern face a deep gap five miles in width separates Aligau and Lowalafuri (Pl. 34, fig. 1), the next island to the north; between it and Kanifuri, the large triangular reef flat which forms the wester'n horn of the atoll, there are only two small reef flats and a small island on the southwest face of Fiuliffolu. Near the centre of the southwestern gap rises Maduwari, a small island, steep to, covered with low vegetation, much of which is dead or dying, as is the case with the vegetation of so many of the islands and islets in the northern part of Male and north of that group. Lowalafuri is steep to; on the western face a steep shingle beach extends into the base of the outer belt of vegetation; much of this is dying; the sea is evidently encroaching upon the south side of the island. - A lagoon extends off the eastern face of the main island, which is joined by a sand-bar to the islet on the eastern rim of the lagoon reef, which probably was once a part of the larger island.

Lohi is also wasting at the sonthern extremity; both it and Kurangdu are steep to on the western face. Some large trees are growing on Kurangdu, though nearly all in a poor condition; this may be due to the effect of the southwest monsoon.

On the west and northwest faces of Fadiffolu we have a series of independent lagoon reefs, most of them with islands such as occur on the plateaus of Tiladummati and Miladummadulu. In the latter case the faros or atolls are often separated by gaps of from five to ten miles, while in the former case they are only from one to three miles apart. A long reef flat forms the western face of the northern pass into Fadiffolu. We entered Fadiffolu by the wide pass south of Maro.

The difference in structure of the southwestern and northwestern faces

1 Two of the eastern reef flats of Fadiffolu lave been figured by Mr. Gardiner and the differences with the Admiralty Chart carefully described by him, loc. cit., 1. 400, fig. 104. 
of Fadiffolu is most marked when compared to similar faces of atolls like Addu, Minikoi, Gaha Faro, or Goifurfehendu, and others where an extensive lagoon flat slopes gradually from the inner face of the outer reef flat towards the deeper part of the lagoon. In such an open group as Fadiffolu where the lagoon reef flat is limited to the slope of the rims of the component faros the difference becomes most striking; we seemed when at anchor off Mafilefuri to be off the steep slope of an isolated atoll with other atolls looming up in the distance.

The gap between Maro and Mafilefuri forms a deep bay, shut off from the sea face by a belt of boulders running across the gap. On the east face of Mafilefuri a lagoon extends northward, parallel to the island. The eastern beaches of Maro and Mafilefuri are alternate stretches of shingle and coral sancl. The islands off our anchorage, like those to the south on the southwest face, are also wasting away. The western faces of Maro and Mafilefuri are flanked by a steep, coarse shingle beach; the western face is steep to; a narrow reef flat, however, exists at the northern extremity of the island.

We skirted the southern face of the triangular reef flat forming the western horn of Fadiffolu. The extremities of the long narrow islands on the southern edge of that flat are generally covered with coarse shingle beaches, they run elose to the southern edge. When not steep to, they are flanked with coral sand beaches or smaller shingle. The point of one of the islets was specially marked by the mass of small boulders at the base of the beach, forming a low wall of modern reef rock. These boulders were angular, undercut, pitted, honeycombed, and greatly weathered. The action of the southwest monsoon on the sonthwest face of Fadiffolu is evidently very considerable. It sweeps north, umbroken, through the open space between Ari and Goifurfehendu, so that the southwest face of Fadiffolu is exposed to its full strength.

To the enst of Kanifuri the outer edge of the reef flat is fringed by sand banks and is protected by a belt of large boulders; on the south shore of Dehu a steep, coarse coral shingle beach encroaches upon the belt of vegetation. Dehu appears to be wasting at its western extremity, where patches of vegetation are standing on the reef flat, and close to the beach 
portions of the belt of bushes are dying. All along the southwest face of Fadiffolu the inclination of the belt of vegretation and its slant to the eastward shows the effect of the southwest monsoon. On the south shore of Kanifuri, which is not quite so exposed to the full sweep of the sonthwest monsoon, the vegetation becomes quite flourishing again. The sonthern beach of Kanifuri is a steep, coarse shingle beach; the island is edged by a narrow reef flat, and is steep to at the western extremity, which forms the western horn of Fadiffolu. From five to seven feet of water are found on the reef flat of the western horn of Fadiffolu.

Though there are no passes through the great southeastern reef flat of Fadiffolu, yet a great mass of water passes over it. On the northeast face, from Faidn the extremity of the reef flat on the southeast face, four narrow reef flats occupy the outer rim as far as Kuredu, the northern horn of the group. ${ }^{1} \quad$ Two of the flats are separated by narrow passes, but the northeastern pass is wide and of considerable deptl.

There are but few rings, banks, and faros within the Fadiffolu group, all in the western parts, the eastern parts of the atoll being quite clear. The greatest depth of Fadiffolu is thirty-two fathoms; the greater number of the soundings are between twenty and twenty-five fathoms.

On the west face of Kanifuri the corals were found to be most flourishing off the western horn, in the belt from eight to nine fathoms, gradually becoming less numerous towards the surface. They extend to seventeen fathoms, where the sand-bars and lanes and patches of sand gradually become wider, separating the coral masses into distinct clusters, until they become irregular, decrease gradually in size, and finally disappear in the belt of dead and dying fragments of corals at the base of the talus of the reef flat.

The trend of the northwest fice of Fadiffolu with reference to the northeast and southwest monsoon is such that it is raked by both, while the eastern and the western faces of most of the groups are raked by only one of the monsoons, and remain under the lee during the season of the other. This readily explains the distribution of the shingle, of the coral sund beaches, and of the boulder belts on the onter edge of the rims of faros

1 Girrliner, loc. cit., 1. 400, fig. 104. 
or of reef flats, as well as the relative number of islands and islets scattered either on the windward or the lee face of the different groups. We might as a rule call the eastern the lee face, for the strength of the northeast monsoon is not to be compared with that of the southwest monsoon upon the western faces of the Maldive Islands. Of course the west face is the lee during the period of the northeast monsoon. These conditions again are somewhat modified to the south from Haddummati to Suvadiva and Addu, where we are outside of the region of the monsoons, in the area of calms and variable equatorial winds.

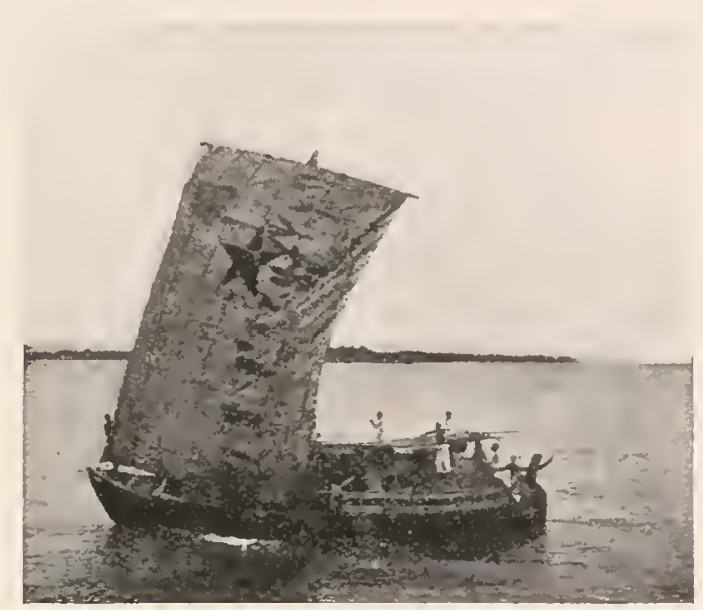

Native Boat, MaLe. 


\section{TILADUMMATI-MILADUMMADULU PLATEAU.}

Plates 1, 2, 3; 8 a, figs. 2-4, 5, 7; 34, fig. 2; 35-53; 79, fig. 3.

Miladumadulu and Tiladummati, the largest and nearly northernmost groups of the Maldives, are in reality parts of the same plateau; their boundary is an artificial one, a mere political division line running east and west sonth of Mavaida (Pls. 2, 3). This great northern plateau is fully eighty miles in length with a greatest breadth of twenty and a minimum width of ten miles. It is in striking contrast to the southern groups, of which the outer faces are more or less well defined by belts of faros or of islands, or by reef flats as in Ari, North and South Malosmadulu, North and South Male, North and South Nilandı (Pls. 1, 4, 5). The outer faces are still better defined in the more southern groups like Mulaku, Felidu, Kolumadulu, Haddummati, Suvadiva and in such smaller atolls as Addu, Goifurfehendu, Makumudu, Ihavandiffulu, Wataru, Gaha Faro, and Karidu.

This northem part of the Maldivian plateau forms a great are convex to the west with a slight indentation in the central part of the western face and one less marked to the south ( $\mathrm{Pls}, 2,3)$. On the east face, however, are two great bights nearly fifteen miles across, forming re-entering curves. The southem part of the interior of the platean is studded for twenty miles with distant islands and faros, some of them of considerable size. They are, however, few in number compared with the many islands, faros, and banks often crowded together as in parts of the interior of North and South Malosmadulu and in some of the central groups like Ari, North and South Male, and Nilandu. In the central part of the platean the islands are less numerous than in the southern part; there are only fifteen in a distance of nearly forty miles, leaving that part of the plateau quite an open sea. In the northern extremity of the plateau the islands are again somewhat more numerous; there are nineteen of them, all except five of considerable size, the largest of the interior islands of Tiladummati. 
The sonthern part of the east face of the Tiladunmati-Miladummadulu Plateau is bounded mainly by distunt erescent-shaped islands or faros with or without sinks or lagoons, and by two large reef flats, on the eastem rim of one of which there are two islands and on the other Kendikolu Island, one of the largest in the Maldives ( $\mathrm{Pl} .3)$. On the southeast face there are two large faros with islands occupying the eastem face of the reef flats, one of which, Ma Faro, is over two miles long and forms the southeastern rim of a small atoll about three and a half miles in greatest length. There is an opening with ten fathoms of water on the northeast face, leading into the lagoon of the atoll, which has a greatest depth of about eight. A conple of islets have been thrown up on the northeastern edge of the rim flat. The other, Edu Faro, to the sonth, is also a small atoll bounded on the enst by a large crescentic island on the outer face of the wide eastern reef flat, which encloses a well-defined, elongated lagoon flanked on the west by a natrow rim flat. It resembles Karidu, but is larger. Atolls similar to Edu Firo, differing, however, in shape, occur on the northern part of the eastern face of Tiladummati. One of them, Hanimadu, is four miles in length.

By far the most interesting feature of the northern hom of Tiladummati are the three atolls which form its northeastern point (Pl. 2). Filadu, the sonthern atoll, with a long bow-shaped island flanking the eastem reef flat, with sinks in the two club-shaped extremities of the island, and a wide pass of nearly a mile in breadth leading into a circular lagoon of nine fithoms in depth, bounded on the sonth by a reef flat nearly two miles wide. Kelai, the northern atoll, forming the castern hom of Tiladummati, is over four miles in length. Its eastern fice is flanked by a large hookshaped island on the onter edge of a wide reef flat, tapering to the west and towards the southwest to form the narrow rim of a large lagoon, with a greatest depth of eight fathoms. The western rim of the lagoon is narrow, much broken, with narrow passages leading into the lagoon through the open western rim. A small island ocenpies the westem hom of the faro. The western atoll, Warifuri, is a pear-shaped faro with a narrow island on the southern edge of the narrow rim of the eastern reef flat; the lagoon enclosed by it is circular and a wide triangular western rim 
reef flat forms the northwestern hom of the faro. The lagoon lias a greatest depth of more than seven fathoms.

Nearly the whole western face of Tiladummati and of Miladummadulu is edged with large faros with or without islands, which may vary from a sand islet to islands of more than a mile in length.

Filadu, Kelai, and Warifuri occupy a striking position. They are placed on the steep edge of the hom of a plateau, which on the eastern face slopes in a distance of about five miles to seven hundred and eighty-one fathoms, on the northern face to six hundred and one fathoms, and two hundred and fifty fathoms in a northwesterly direction, while the depth of the central part of the plateau within the area enclosed by these lagoon reefs is nowhere greater than twenty-nine fathoms. So that on the theory of subsidence we should have to accomt for the sinking of the eastern face of Kelai, Filadu, and Baura to a depth of over seven hundred fathoms, while the western faces werc formed during a subsidence of less than thirty fathoms. On the same theory the southern faces of Kelai, Warifuri, and the other lagoon reefs of the northern face of Tiladummati were formed during a subsidence of from twenty to thirty fathoms, while the northerm faces subsided from two hundred and fifty to six hundred fathoms! Again, in the same inner basin of Tiladummati and Niladmmmaduln are a number of smaller lagoon reefs, atolls in every sense of the word, which on the theory of subsidence could only have been formed during a subsidence of about thirty fathoms. Some of them in the central part of the group have become islands; others are still lagoon reefs, as will be seen by a glance at the charts. To the former category belong Muradu, Mahafai, Kumberidu, and nearly all the islands in the central part of Tiladummati and Miladummadulu, such as Faidu, Madidu, Kandute, Rebudu, and a number of small and nameless islands in the eastern and southern part of Miladummadulu. To the latter series belong Goadu, Maruri, Wagaru with a lagoon of eight fathoms in depth, Kabafaro, Dureadu with a lagoon of eightecn fathoms in depth, Maddedı with a lagoon of eight fathoms, and a number of unnaned rings and diminutive lagoon reefs in the southern part of Miladummadulu.

The conditions which have shaped the formation of the faros of the reefs and islands of Tiladummati and Miladummadulu are similar to those which 
have led to the formation of the faros, the inner and outer lagoon reefs of North and South Malosmadulı, of North and South Male, of Ari, of Nilandu, and other Maldive groups. They show in great detail that subsidence cannot account for the formation of atolls upon banks of such great differences in depth as those of the Maldives, and all within short distances of one another. It would require an irregularity and a range in the vertical oscillations of different parts of the Maldivian plateau entirely without precedent. The deepest soundings indicated on the chart for the Tiladummati-Miladummadulu plateau is thirty fathoms, but the greatest number of soundings range between twenty and twenty-four fathoms.

Entering, as we did, Miladummadulu from the west, to the sonth of Digu Faro (Pl. 2), one cannot fail to observe, looking either east or soutl, low little land is visible, how open and nnobstructed is this stretch of Miladummadulu, and how exposed are its opposite shores, according to the season, to the full action of the prevailing winds. One gets quite the impression of being in the open sen, with a few islands looming up here and there on the horizon. They are, however, so far apart and so few and insignificant in size, that they afford little or no shelter from the monsoons to islands even at a small distance. A glance at the chart cannot fail to bring this ont. Great stretches of the interior of the central and northern part of Miladummadulu are bare of islands, with here and there a diminutive patch. They give the impression of a great open tract of sea, - fully sustained when one steams through the area delineated on the chart.

The most characteristic features of this platean are the open nature of the interior waters and the number and great width and depth of the passages between the islands and faros on the outer faces of the group. On the central part of the east face is a wide opening nearly ten miles across; five passages are over four miles in width, four are nearly three miles wide, twelve are over two miles, and five are two, with at least fifteen or sisteen passes of a mile between the smaller islands and faros. On the west face there are nine passes of more than one and a half miles. In fact, the length of deep open water on the fices of the Tiladummati-Milidummadulu group far exceeds in length that of the islands, faros, and flats 
(Pls. 2, 3), a condition which can hardly be called that of an atoll. Such a state of things seems to indicate that coral reefs and atolls may begin at any point or knoll or ridge or range or summit or flat of a platean, having the depth at which corals may begin to form, provided its waters have the necessary temperature and the proper exposure to currents or trades. The surface of the Maldivian platean consists of a lost of such knolls, summits, and ridges of greater or less dimension, upon which have risen the complicated system of islands, faros, reef flats, and atolls with which we have become familiar during our exploration of the Maldives.

To understand the coral reefs of the Maldives, we must look upon each ring or faro or islet or island on a reef flat as a thing by itself, just as much entitled to be caller an atoll as any of the smaller atolls found in the Pacifie, - atolls which only incidentally play a secondary part as reef flats of the outer faces of the grroups, but which in spite of their position do not hold to the enclosed water the same relation which the reef flats or land rim of an atoll hold to the enclosed lagroon.

Nowhere in the Maldives have we met with better examples of the modifying effect of the regular southwest and northeast monsoons as compared to the effect of winds in regions of southerly variable winds and squalls than in the northernmost groups of the Maldives. One can readily trace the direct action of the monsoons upou similar islands when situated either on the east or west face or on the inner waters of the group. Of course all that part of the Tiladummati and Miladummadulu groups which lies north of North Malosmadulu cannot fail to be greatly affected by the action of the southwest monsoon on the western face of the group. ${ }^{1}$ Entering Tiladummati to the south of Muradu, we had to stem a current sweeping west with great violence, it being the season of the northeast monsoon.

It is interesting to note the changres which have taken place in the outlines of many of the islands on the rim reef flats of both the western and eastern faros of the group since 1836. Some of the islands which were isolated at that time and are represented on the charts als single distant islands on opposite extremities of the rim of a fino have either both greatly

1 Gardiner, loc. cit, p. 315, has called attention to the small importance of the agency even of heavy gales on the edges of the reefs. 
increased in size so as nearly to become mited, or they form only a single crescent-shaped island on the outer edge of the rim reef flat. The further change these crescentic islands undergo from the action of the monsoons are often very striking. In fact, the erescent-shaped islands on the east face of the group almost seem to move in the direction of the prevailing monsoon, like great horseshoe-shaped dunes. Only their motion is linited to the extension of the horns of the crescent in the direction of the wind until the horns have locked, and the ring, once a crescent-shaped island partly enclosing a small lagoon, ends in completely surromending the lagoon and forming the typical and mythical atoll so often described by writers on geography, but which really is only found very rarely in the great atoll regions of the Pacific, but finds its greatest development in the thousand isles of the Maldives. The islands of the interior of the platean are wasting; the imner banks appear to be all of the same height; and from the bridge we could see no indications, from the discoloration of the water, of banks growing up or having come near the surface.

The crescentic islands on the eastern face of the northern part of Tiladummati show this process of growth admirably, and there we can readily trace the development of a large single island from two smaller islands placed at each extremity of the atoll. We need only look at the charts and follow the gradual junction of the two islands of Hanimadu now connected by a low narrow sand spit, or those of Filadu or of Baura and Kelai or Noliwang Faro, and pass to such an island as Kuludu Faro, which occupies fully one half of the faro flat, to Komangdu and finally to Nuriwari, each occupying a gradually greater part of the reef flat rim till the island occupies the whole, and appears as at circular or elliptical island steep to, surroumded by an insignificant fringing reef flat!

\section{Miladummadulu.}

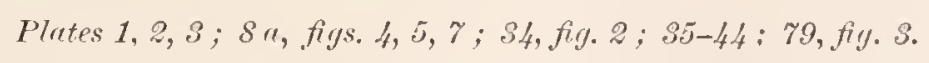

The southern part of Karema, the southernmost island on the south face of Miladummadulu, is wasting away; many of the trees and bushes are well 
out on the small reef flat of the southern end of the island.' Karema, like most of the islands on the outer faces of Miladummadulu, is steep to ; it is bordered by coral sand beaches. On Wataru (Pl. 34, fig. 2 ; 35, fig. 1), to the northeast of Karema, a large island occupies the southern rim of the faro. The vegetation of the island is poor; most of it is dead or dying, the sand and shingle of the high steep beaches having been blown far in between the trees through the onter belt of bushes. The southwest monsoon must strike the south face of Miladummadulu with considerable force; the tops of many of the cocoanut-trees are blown off, leaving nothing but the trunks. The lagoon of Wataru is circular and occupies the northern part of the faro; it is surromded by comparatively wide rims and has a greatest depth of threc fathoms. On Wataru flats as well as on the southern flat rims of the east face of Edu Faro are extensive violet and dark green patches of corals. The south face of the southem island of Edu Faro is bordered by steep shingle beaches, and a belt of boulders and shingle extends along the outer edge of the reef flats. Edu Faro (Pl. 35, fig. 2) is steep to, with an extremely narrow reef flat on the sea face. The long lagoon to the west of the wide eastern rim is shallow; its greatest depth is only three fathoms; it is flanked on the west by a moderately wide reef flat rim.

The two islands on the eastern face of Edu Faro (Pl. 35, fig. 2) must once have been separated by a gap of greater width than the one now existing. From the opposing extremities of the islands are forming extensive sand spits and sand flats broken up into a number of bars and islands and islets, covered with more or less vegetation. These islets, bars, and spits, as is more clearly seen in more northerly islands of this group, will eventually unite into one large island.

Denduni and a nameless island to the eastward with a wide reef flat on the northern face present no peculiar features; they both are steep to, and have steep coral sand beaches with an outer belt of low bushes and rather scanty vegetation. On Huludu, a small island nearer the western face of

1 Darwin, loc, cit, p. 103, mentions that one of the Maldive reefs "which witlin a fuw years existed as an islet, bearing cocoanut-trees, was found by Lientenant Prentiee, entirely covered with live corals and Madrepore." The nalives believe that the islet was washed away. Darwin, however, attributes the eliange to subsidence. 
Miladummadulu, the vegetation is again quite flourishing; some large forest trees occur on the western face. Huludu is also steep to and flanked by steep coral sand beaches. Similarly Lofara and Watu, small islands to the south of which we passed, have steep coral sand beaches, are steep to, and covered with scanty vegetation.

All the islands of the southern part of Miladummaduln, with their high and steep coral sand beaches, enclosing an inner area somewhat lower than the summit of the beaches, give one the impression of being slightly dished.

Mavila, on the west face of Miladummadulu, is a triangular island with a reef flat on the northwestern face. It is steep to, surrounded with steep coral sand beaches, and fuirly well wooded; some of the trees on the eastern point are of considerable size. About six miles to the north on the west face of Miladummadulu, and separated from it by a circular furo of fully two miles in diameter, with a lagoon of a greatest depth of eight fathoms, rises Digu Faro, an elliptical faro pointed to the south. The small islet with its clump of trees indicated on the ehart as existing on the southern spit of the faro has disappeared; nothing can be seen but a diminutive sand bank on which a few terns were collected.

Deha Faro consists of two small islands on opposite faces of an irregular elliptical reef flat covered with low bushes; they are bounded by coral sand beaches; the eastern island is wasting away; the outer belt of bushes runs close to the water's edgre.

Maddedn (Pl. 36, fig. 1), in the very centre of the southern part of the group, is a triangular faro with a reef flat occupying the eastern part and an island at its eastern spit; while the western half is a small lagoon, bounded by a sunken narrow rim flat, having a greatest depth of eight fathoms. The island is covered with low vegetation, much of it in a dying condition; the eastern face is wasting; the outer edge of the reef flat is bordered by a belt of boulders; a beach of coarse coral shingle flanks the east face.

To the southeastward of our track we passed by Tolandu, a small steep-to island on the east face of the group, with a scanty outer belt of low bushes surrounding the cocoanuts of the interior of the island. The western face is a long steep coral sand beach; the base of the coarse 
coral shingle beach of the northeast face is edged by a belt of boulders; as far as we could judge from the charts, and from what we saw of the small islands to the north and west of Ma Faro, they present no special features of interest. The deep pass with a depth of ten fathoms leading into the lagoon of Ma Faro, with its islets in the reef flats in addition to its larger island flanking the east face, gives to that faro all the appearance of a small atoll. ${ }^{1}$

Kendikoln (Pl. 37) is one of the largest reef flats of the sonthern part of the east face of Miladummadulu, the greater part of which is oecupied by the island of Kendikolu, one of the largest in the Maldives. It is steep to on the east face; the western face is occupied by a comparatively narrow reef flat somewhat wider at the northem extremity. The sontherm point of Kendikolu is bordered by steep shingle beaches, while all the way to the north extends a magnificent steep coral sand beach. Corals grow in great profusion on the slope off the western face of Kendikolu. The island is noted for the long sinks which oecupy the greater part of the central portion of the island. We visited the northerm one (Pl. 38); it is somewhat nearer the eastern face of the island, separated from it only by a narrow ridge of shingle and of sand. The depth of this brackish pool is only about eighteen inches; its shores are overgrown with mangroves. There are many Pandanus, Hibiscus, Breadfruit, and other forest trees on Kendikolu; the vegetation is quite dense.

The islands on the eastern face of Miladummaduln to the north of Kendikolı, as far as Nalandu (Pls. 2, 3), proved most interesting. In general they are small crescentic islands occupying a greater or less area of the edge of the rim reef flat of the faro cncircling in part a small lagoon. From this stage we find all possible conditions of devclopment from a closed ring surronnding a diminntive lagoon or only a sink in an island where all trace of its mode of formation has disappenred.

Komandu (Pl. 36, fig. 2) is a cireular island, stecp to, with large boulders on the south beach; a coarse shingle beach extends round the eastern face, and a steep sand beach flanks the west side. A small reef flat covered with shingle extends off the north point. The vegetation of both Komandu and

1 Ma Faro is three and a laalf miles long, Gardiner, loc. cit., p. 395. 
of Breyfasdu (Pl. 39, fig. 1) is tall and dense; the latter has, like the former, a stretch of large boulders on the southeast face. ${ }^{1}$ Both islands are wasting away.

In Bomasdu (Pl. 39, fig. 2) the lagoon has become entirely silted up; nothing is left of it except a very shallow sink almost filled with patches of sand, which cross it in every direction. The sand beaches of the sea face are steep; the outer edge of the reef rim flat is crowded with large patches of flourishing corals.

Bodu Mandu (Pl. 40, fig. 1), also on the east face of Miladummadulu, is steep to; the greater part of the lagoon has been filled up to the general level of the rim reef flat; the lagoon is shut off from the sea by a steep shingle beach which now joins the two horns of the erescent-shaped island and eneloses a lagoon with a depth of five fathoms. In 1836 this lagoon was, according to the chart, connected with the sea across the narrow still slightly submerged rim reef flat, but it is now elosed. In all the crescentshaped or linear or other islands on the reef flats of the faros of the east face of Miladummadulu or of other groups which have increased in size and been formed by the coalescence of smaller islands, it is always possible to detect, by the difference in the eharacter of the vegetation, those parts of the land rim which are of more recent origin and have grown up on the connecting spits or horns. No atoll we have seen shows in a simpler and more convincing manner than Bollu Mandu how an enclosed lagoon of considerable depth, completely shut off from the sea, has been formed by the throwing up of a shingle dam comnecting the horns of the crescentshaped island and enelosing a part of the old rim flat and central area of the faro.

In Kuda Mandu (Pl. 40, fig. 2), the next atoll to the north, the lagoon is not quite shut off, it is only partly closed by a bar of shingle thrown up on the shallow rim of the reef flat. There is to the eastward of the bar a boat passage giving free access to the sea at all stages of the tide.

Another interesting crescent-shaped atoll is Dureadu (Pls. 41, 42, fig. 1), situated in the centre of the narrowest part of Miladummadulu. It is a faro

1 IIainbuddu I did not visit. According to Gardiner, loc. cit., p. 394, it is unique anong the Maldives in having a definite reef flat on all sides except the west. 
or atoll with a wide-rimmed reef flat that has only reached the surface, close to the homs of the island. The rest of the rim flat is submerged, leaving the lagoon open for the whole width of the faro, with as much as five fathons of water on parts of the rim. The principal island of Dureadu is clothed with luxuriant vegetation; at the extremity of the eastern horn rises a small island covered with large bushes and separated from the principal island by a line of large coral boulders. The east face of the islet and of the principal island is flanked by a shingle beach with stretches of small coral boulders which extend also on the northern face of the main island of the atoll. The lagoon of Dureadu is one of the deepest of the small independent atolls in the Maldives; it is fully a mile across with a depth of eighteen fathoms. Dureadu resembles Nalandu, though the lagoon of the latter is much smaller and its greatest depth is not more than two fathoms. ${ }^{1}$

All the islands we passed on the east face of Miladummadulu are steep to; there are no reef flats or spits extending from the flats on the lee side, as in the islands of many of the other groups. The original flats must have been limited to the areas now occupied by the islands or faros.

Ekasdu (Pls. 42, fig. 2; 43) is perhaps the most advanced stage of an enclused central lagoon. It could be well seen from aloft. The outer beaches are all steep coarse shingle slopes. The lagoon of Fkasdu is of a dark blue color, indicating a depth fully as great as that of the lagoon of Bodu Mandu with a greatest depth of five fathoms.

Ereadu, the next island to the north, though less than a mile in diameter, is the largest of the chain of small islands between Kuludı and Furnadu on the east face of Miladummadulu. The crescent-shaped island, open to the west, encloses within its homs an elliptical lagroon, slallow at its southern extremity with a wide shallow western rim over which the sea flows freely into the lagoon; parts of the rim are barely awash. Ereadu represents one of the earliest stages in the closing off of a lagoon where no dam or shingle heap has as yet been thrown up on the reef flat between the horns.

1 Of the central islands it was only at Dureadu that Gardiner found on the northwest faee the existence of a definite but very limited reef flat with a well-formed fissure zone of gradual slope to the general level, loc. cit, p. 388. 
The reef flat enclosing the islands of Furnadu (Pl. 44, fig. 1) and Farukolu $^{1}$ is nearly two miles wide and four in length; the islands are separated by a wide reef flat with islets and sand banks thrown up on the onter edge of the eastern fice. At the extremities of the central part of the reef flat a small shallow lagoon has been formed. The western face of the reef flat is covered with patches of flourishing corals. The two islands are hook-shaped; the narrow deep bays formed by the extension of the hooks or spits to the north and south enclose a shallow part of the reef flats, indicating clearly how the shallow sinks of such islands as Kulndu and Kendikolu are formed. Such sinks or lagoons or rather shallow enclosed bays of parts of the reef flats must not be confounded with the enclosed lagoons of faros of such islands as Nalandu, Milandu, and the small crescent-shaped islands to the south or the larger crescent-shaped islands on the northeastern horn of Tiladummati. Sinks or enclosed bays like those of Kulndu exist on Makindudu and to the north in Kuludu Faro, and the two extremities of Filadu. In the northem faros, as in Kuludu, these sinks occur on faros or atolls where the lagoons are well developed, plainly showing the distinet differences in the mode of formation of the two.

The northwestern point of Makandudn is flanked by a large pile of coral boulders and beach rock slabs on the east face, exposed to the northeast monsoon; the island is bounded by steep coral shingle beaches. The island is steep to with a small shallow sink in the eentral part of the island.

The southern face of Milandu is wasting away; off the beach great clumps of trees and bushes are standing on the reef flat. The coral shingle has been driven by the southwest monsoon far in between the elumps of trees and bushes. Milandu is a narrow creseent-shaped island, somewhat dumb-bell-shapecl; it lies on the outer edge of the eastern reef flat which forms the eastern rim of the shallow lagoon enclosed between it and the westem rim flat. On the chart the greatest depth of the lagoon is marked as two fathoms; its light green color would not indicate even that depth. The western rim flat connecting the horns of the island is quite shallow, the sea breaking over the greater part of it. The horns of the island have extended westward somewhat beyond the position indicated

Gardiner, loc. cit, p. 391, lig. 99. 
on the chart, the opening into the lagoon over the western rim being much narrower than when it was surveyed in 1836. The beaches of Milandu are all steep, of coral shingle, even the inner beaches flanking the eastern face of the lagoon. The dumb-bell shape of the crescent-shaped Milandu Island indicates that at one time there were two islands on the extremities of the reef tlats of the faro; the spits making both ways and extending north and south from them, they gradually joined and finally formed a single crescentic island.

The structure of Nalandu (Pl. 44, fig. 2), the northernmost of the crescent-shaped islands of Miladummadulu, throws considerable light on the mode of formation of atolls which, like Kuludu, Filadu, and others, have both a lagoon and a sink, or enclosed bay, once forming a part of the outer rim reef flat. Nalandu is a small island, less than a mile in diameter, with a lagoon two fathoms deep and a pass open to the south; it also has a closed sink or bay, one fathom in depth, communicating with the lagoon and considerably larger than the lagoon itself. At low tide a great part of the sink is bare, the bottom being fine coral ooze; it is an exceedingly pretty sheet of water surrounded on all sides by clumps of large forest trees, with bays and bights reaching out from all faces. The sink is separated from the eastern part of the lagoon by a low sand point covered with a thick tangle of bushes and trees; a wide rim covered by tall forest trees and mangroves divides it from the sea on the eastern and western sides; it is flanked on the north by a narrow rim flat. On the onter face Nalandu is surrounded by steep coral shingle beaches; off the western face of the island lies a small reef flat awash; on its onter edge a belt of boulders and heaps of shingle have been thrown up; they pass into the boulder and shingle spits of the horns of the island. 'The southeastern face of the island, as well as the western point, is wasting away.

To the west of Ereadu begins an inner line of small, steep to islands, with the exception of Kabafaro, which is crescent-shaped and flanked by a small reef flat. This imner line of islands runs northerly from Ereadu to Fivaku, nearly parallel to the eastern face of Miladummadulu, at a distance of from two to three miles. They have no distinguishing features from similar inner or outer islands of other groups in the Maldives. 
We passed at a short distance off Kuraidu, the northernmost of this inner chain of islands; its sonthern face is flanked by steep, coarse shingle beaches, with a mass of boulders along the southwestern point. The island is steep to; its vegetation is scanty. Faidu and Marlidu, which are more in the central part of the group, are steep to, and both have, according to the chart, small central sinks. They are, like Kuraidu, surrounded by steep, coarse shingle beaches. The vegetation of both is poor; it seems to be affected by the action of the sonthwest monsoon.

Looking to the northeast, while off Madidu, we are facing the great central gap of Miladummadulu, between Fivaku and Mavaidu, nearly fifteen miles wide, with only $\mathrm{Nu}$ and Numara on the horizon across this great and deep passage.

On the western face of Miladummadulu, to the sonth of Bilifuri, are a number of large faros and reef flats and islands, similar in all respeets, according to the charts, to those we examined, as well as a few small islands scattered towards the centre of Miladummadulu to the north of Dureadu, similar to the inner line of small islands near the east face of the group.

Kofenbe, to the south of our track, is a large faro over two miles in diameter, with a lagoon of a greatest depth of three fathoms, and a wide rim flat. A large triangular island oceupies the greater part of the eastern rim. The vegetation eonsists of low bushes, though on the eastem face there are a few elumps of large trees. The island is flanked by steep coarse coral shingle beaches.

The island of Bilifuri occupies a good part of the eastern rim flat of the faro. The southern extremity of the island seems to be extending westward as a sand spit forming the northern face of a small bay surrounded with large forest trees. The southern spit itself is flanked by a coarse coral shingle beach. The island is covered by fine trees and a thick outer belt of bushes and smaller trees. Along the eastern face of the islind the steep shingle beaches are of still coarser material, with an outer belt of coral boulders as large, if not larger, than any we have seen thus far in the Maldives. Close to the northern point of the island the narrow entrance to the lagoon is still plainly visible, and as we swept past it we obtained an 
excellent view of the western shore of the island and of the part of the lagoon enclosed by the wide rim of the reef flat on the western face of the faro. The lagoon of Bilifuri is quite shallow; its depth is not more than one and a half to two fathoms; its light-green color scarcely marking the outline of the lagoon, blended as it is with the greenish tints of the wide rim enclosing it, and covered with a few feet of water; on the northem face of the rim flat the sea breaks along the outer edge and all the way across. Beyond the diminutive pass into the lagoon the outer edge of the rim reef flat is flanked by a belt of heaps of shingle and of small boulders. Magnificent coral patches dot the outer rim of Bilifuri as well as of the eastern rim flat of the large faro to the north of it on the western face of Miladummadulu. This large faro is over four miles in length, pear-shaped; the larger of the enclosed lagoons is open at the northern extremity of the faro; near the southern face a smaller circular lagoon less than half a mile in diameter is enclosed by the wide crescentic reef flat rim of the faro. The narrow sand bank on the eastem face of the faro is scantily covered with trees and an outer belt of small bushes. The beaches of the narrow islet of the faro to the north of Bilifuri are flanked with beach rock, and near the northern point with a few boulders at the base of the steep, coarse shingle beaches. Much of the beach rock and some of the boulder reaches are undercut, pitted, honeycombed, and greatly weathered. Stretches of this weathered coral boulder belt extend along the northeastern face of the faro; they indicate a former slightly greater elevation.

As we passed out of Miladummadulu west of Goadu, we steamed by the long narrow channel leading into the lagoon at the tip of the northwest horn of the faro to the west of Goadu, a mere strip of light-blue water flanked on both sides by a light-greenish flat rim.

Kandute and Goadu are the two northernmost islands of the west face of Miladummadulu. To the north of them a large elliptical faro nearly five miles in length, with a spur off its eastern face, marks the artificial northern boundary drawn east to west between Tiladummati and Miladummadulu. Kandute and Goadu are both flanked with saudy beaches along the eastern part of the faces of the islands, while steep shingle beaches surround the 
western extremities. At the western extremity of Kandute a small detached island rises upon the suall reef flat; it is flanked with beach rock and coral boulder masses, greatly weathered. That part of the island is exposed to the full force of the southwest monsoon.

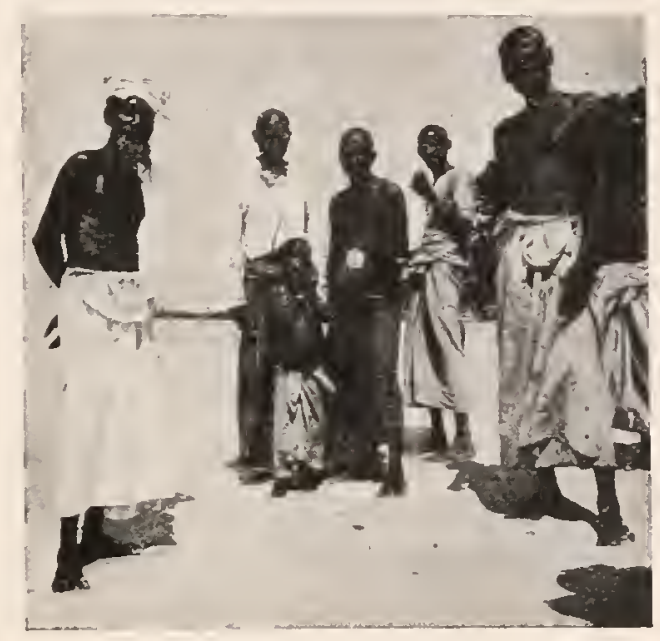

Natrives of Kuludu.

\section{Tiladummati.}

Plates 1, 2; 8 a, figs. 2,$3 ; 45-58$.

Immediately north of the artificial boundary drawn between Miladummadnlu and Tiladummati, on the west face, lies a bank with irregular soundings varying from three to fourteen fathoms (Pl. 2). Next, to the north, comes Muradn (Pls. 45; 46, fig. 1), a circular faro of about two miles in diameter with a wide rim reef flat. On the chart of 1836 a long narrow island is drawn upon the eastern face of the rim flat, and a smaller island on the inner edge of the western rim (Pl. 2). We were surprised to find that these two islands are now comected, forming a single crescent-shaped island, a long sand spit having extended from each somewhat diagonally across the inner face of the northern rim. They are connected by a high coral sand ridge partly covered with low bushes and a scanty vegetation near the old islands, and bare on the more recent central part. The 
original islands form knobs at the extremities of the single somewhat dumbbell-shaped island. The onter edge of the sonthern reef rim flat is bordered by small boulders, and the eastern face of the island is flanked by shingle beaches and boulders.

The outer belt of the rim of the large pear-shaped faro to the north of Muradu is, with the exception of a belt of large boulders on the northern face of the ring, covered with patches of flomishing corals. 'The northern rim reef flat of the faro slopes into deeper water than the shallower southem rim. There is no well-marked pass into the central lagoon.

The next faro to the north is elliptical, with a wide opening leading from the east into the central lagoon; this is bounded by a wide reef flat rim on the southern face. On the horn of the southem rim flat a few large boulders stand as sentinels at the entrance, with heaps of shingle on the northern rim; the opening of the pass is flanked by isolated boulders, and to the westward, on the northern face, the faro is bordered by a long reach of large boulders. A small sand bank has been thrown up on the inner face of the northern rim near the pass; this is not shown on the chart.

Muadu is a faro to the northeast of the last, dividing the eastern entrance of the wide and deep pass between it and Naguri into a northern and southern chamel. The eastem end of Muadn is occupied by a long triangular island, which has thrown out along the northern rim a sand spit covered with low bushes. A similar coral sand spit extends along the southern face of the faro enclosing in part a wide bay; these spits enclose the greater part of the lagoon of the faro. From the northwestern corner of the island a coral sand spit forms the western boundary of a wide bay open to the north. The southern face of the faro is bordered by a belt of boulders and the eastern face of the island is flanked by steep, coarse coral shingle beaches.

Naguri (Pls. 46, fig. 2; 47) is a large faro nearly three miles in diameter with a large island extending towards the central part of the lagoon, clubshaped at the western extremity and T-shaped at the eastern. The southern rim flat is flanked by a low wall of shingle and large angular undercut bonlders, all greatly weathered and separated from the beaches of the island by a shallow reef flat. The club-shaped and the T-shaped parts of the 
island were evidently once distinct islands, the one on the outer edge of the eastern rim flat, the other extending across the wide southern rim of the faro. They have become united by a high sand bank, the extension of the shank of the T-shaped island.

The island of Mulieri, about two niles east of Naguri, represents the type of islands characteristic of the inner waters of Tiladummati. They are all steep to with ligh beaches, generally shingle beaches on the southwest faces and coral sand beaches on the northern ones; according to the trend of the islands and their greater or less exposure to the prevailing monsoons, they have wider or narrower reef flats, with accumulations of small boulders at the terminal spits.

Kurimbe Island in the central part of Tiladummati is about a mile in length, steep to, with high and steep shingle beaches on the northern as well as on the southern face, they are exposed to the southwest and the northeast monsoon, both of which have a sweep of considerable extent over that part of the central area of Tiladummati. The shingle beaches alternate with sandy reaches, according to the position of the shore with reference to the prevailing winds. The summit of the sand beach of the central part of the southem face of Kurimbe is fully fifteen feet high, and at other points it is from eleven to twelve feet high. A coarse, high, and stcep shingle beach flanks the southeastem point of Kurimbe, and huge boulders are scattered along the edge of the narrow reef flats of the point. Kurimbe is surrounded by an outer belt of large bushes and smaller trees, enclosing several fine clumps of large forest trees.

On the northern islands of Tiladummati and at Makunudu we find many Pandanus; they are not as common in the central and sonthern parts of the Maldives. There are some large forest trees on the northern points of Kurimbe and Kumberidu (Pl. 48, fig. 2). On both these islands as well as on the northern islands of Tiladummati, both the shingle and sand beaches are much higher and steeper than in any of the southern groups.

Kurimbe, Kumberidu, as well as Mahafai, Muradu, two inner islands near the northern part of Tiladummati, and a few other islands in the central part of Tiladummati which we did not visit, belong to the same 
type as Muheri. We examined Mahafai and Muradı (Pl. 48, fig. 1), two of the inner islands near the northeastern extrenity of Tiladummati. They are both steep to on the eastern face and flanked by steep shingle beaches on the east face with steep coral sand beaches along the western side (Pl. 49, fig. 2); on the western face of Mahafai there is a narrow reef flat.

We examined the faros on the east and north faces of Tiladummati, north of Nuriwari. Those on the east face all have islands on the eastern rims of the faros occupying a great part of the area of the eastern reef flat. The southern point of Nuriwari is covered by low vegetation, swept by the prevailing winds; the island is flanked by high, steep, coral sand beaches driven far into the outer belt of bushes. At the northern point and on the eastern part of the morth face, which is evidently wasting away, large coral boulders are found along the outer edge of the rim of the diminutive secondary lagoon at that extremity of the island.

At the southern extremity of the crescentic-shaped island of Noliwang Faro, a few isolated islands and islets flanked with coarse shingle and covered with tall bushes rise on the reef flat rim; the edge of the reef flat is bordered by a few boulders. The small islands form the eastern face of the entrance to the shallow lagoon extending off the west face of the island; the western face of the pass is indicated by an accumulation of coral shingle. The western rim of the lagoon is narrow with but few coral patches on the rim of the slope which falls off very gradually towards the west. The northerm part of the island of Noliwang Faro is clubshaped, with a hook-like extension to the south, occupying the northern part of the western rim reef flat, partly enclosing a deep, open shallow bay. This northern part was clearly at one time an island distinct from the southern extremity; it is now connected with it by a long coral sand ridge; the vegetation of the connecting ridge clearly indicates that its formation is of more recent date than that of the two extremities.

The eastern rim of Hanimadu, the next atoll to the north, is flanked by a convex dumb-bell-shaped island, the clubs of which are united by a very narrow coral sand ridge; this gradually reached north and south from the disconnected extremities of the original islands at the northern and southern 
horns of the atoll until the spits joined in the central part of the rim of the east face. The vegetation of the connecting ridge was undoubtedly at one time as scanty as that of the more recently formed connecting ridge betwcen the two islands of Muradu on the western face of Tiladummati. The western face of the northern part of Hanimadu is flanked by a coarse coral shingle beach which must have been thrown up on that face of the island before the formation of the ridge connecting the north and south islands of the atoll. The connecting ridge is very narrow, as one can see the eastem face of the atoll throngh the low belt of bushes growing upon it; the western rim of the shallow lagoon in the southern part of the atoll is narrow; the wide reef flat rim to the north of the lagoon is shallow. Hanimadu is a narrow atoll about four miles in length with a greatest width of a mile.

At our anchorage off Hanimadu we seemed to be surrounded by land, and well shut in by islands rising up in all directions; in marked contrast to the open character of the platean south of the boundary between Miladummadulu and Tiladummati as seen from the western face looking towards the wide open gap between Mavaidu and Fivaku.

Seen by moonlight with the moon high above the horizon, the rims of the faros present a most striking appearance; they appear like great flats painted a dull white with the thin glaring line of coral sand-beach in the background topped with the dark line of vegetation. The flats stand out so prominently that one might alınost be tempted to navigate between the islands at night.

Baura (Pl. 49, fig. 1), the next atoll to the north of IIanimadn, is a circular lagoon reef over two miles in diameter, surrounding a small central lagoon with a greatest depth of three fathoms. The sontherm half of the reef flat is occupied by a broad dumb-bell-shaped crescentic island open to the north. The land of the sonthern rim of Baura undoubtedly consisted at one time of two distinct islands situated the one on the eastern, the other on the western face of the reef flat. These islands have become united by a broad ridge in the same manner as we have described the jumction of other crescentic islands on the east face of Tiladummati. Seen from the north across the wide rim, the central lagoon forms a deep bay betwcen the two horns 
of Baura. On the sea face of Banla the beaches are covered by coarse coral shingle, and the outer edge of the reef flat is flanked by a belt of large boulders.

The larger crescent-shaped islands on the eastern face of Tiladummati, such as Hanimadu, Baura, Filadu, Kelai, have, like Muradu and Naguri on the west face and others elsewhere in the Maldives, been formed by the coalescence of separate islands, gradually united into one by the extension of sand spits and bars. This is admirably shown both in Hanimadu and Filadu (Pl. 50, fig. 1); in the latter the comnecting ridge is a mere sand-dam. flanked by shingle on the sea face, and so low and so narrow that, steaming along the sea face, one can look across far over the reef flat rim of the western face of the lagoon reef.

The lagoon reef of Filicdu was at one time a lagoon open to the north with a wide eastern reef flat rim, on the northern and southern extremities of which were situated small islands (much as at Muradu in 1835); these must have gradually increased in size and become united by a narrow sand ridge reaching little by little north or south from the existing terminal islands, - a connection at first made by sand-bars or by piles of shingles. The vegetation of the connecting ridge of Filadu consists of low bushes and is in marked contrast with that of its club-shaped extremities. The lagoon reef of Filadu is nothing but a small atoll, with a well-defined land rim, a broad reef flat, and an opening nearly a mile wide with three fathoms of water leading into the lagoon, the greatest depth of which is nine fathoms. A small islet of coarse coral shingle, not indicated on the chart, marks the horn of the reef flat rim on the westem side of the pass into the lagoon. There is a secondary lagoon in each of the extremities of Filadu; the northern one we could look into as we passed; its color indicated a depth of about one fathom, probably formed like that of Kuludu.

Filadu, Kelai (Pl. 50, fig. 2), and Warifuri (Pl. 51, fig. 2), the three lagoon reefs forming the northeastern horn of Tiladummati, are in reality three atolls of considerable size. Kelai is over four miles in length and nearly two miles wide, Filadu is about three miles in length and two miles in greatest width, while Warifuri is somewhat smaller.

On the western face of Kelai, there is an entrance to the lagoon, with a 
depth of three fathoms, somewhat blocked by coral heads and sand banks. The northern side of the entrance is narked by a low sandy islet at the western extremity of the narrow northern rim of the lagoon, the depth of which varies from four to eight fathoms. The western rim of the lagoon is narrow, and both the northern and southern rims are extensions, tapering westward, of the wide reef flat rim on the eastern face of the lagoon reef, the greater part of which is occupied by the donble hook-shaped island of Kelai.

The widest reef flat rim of the lagoon reef of Warifuri forms the northwestern horn of the atoll, its southwestern rim is quite narrow as well as the sonthern rim reef flat, which is edged by a long narrow coral sand island covered with low vegetation, and from each extremity long sand-bars are extending northward along the western and eastern rims of the lagoon reef. The lagoon of Warifuri has a greatest depth of over seven fathoms. Two small narrow islands covered with low vegetation extend along a part of the northern rim of Warifuri. In the course of time these islands may reach south on the western reef and unite with the sonthern island so as to form a single island on the western face of the lagoon reef, as we find it to be the case with Gafuri and Miledn, two lagoon reefs to the westward on the northern face of Tiladummati, in both of which the islands are on the western rim flat, as are also usually the widest rim flats on the faros of the western face of Tiladummati.

Dedu (Pl. 51, fig. 1) occupies the eastern face of a triangular lagoon reef, the western rim of which is narrow; at one time it was composed of two islands now united by a central comnecting ridge, as can be seen from the character of the vegetation covering the ridge.

The western part of the southern rim of Gafuri is bordered by a wide belt of boulders extending northward from Dunacoori ( $\mathrm{Pl}$. 52, fig. 1), a small islet at the southern horn of the rim. The southern part of the lagoon is very shallow, though the charts indicate a depth of seven fathoms at the northem end of the lagoon. Gafuri is separated from an adjoining ring to the west by a very narrow deep channel, a mere line of dark-blue water of a depth of ten fathoms. The outer edge of the wide rim of the ring is crowded with large colored patehes of corals extending nearly to the edge of the small lagroon of the ring. 
The eastern face of Miledn (Pl. 52, fig. 2) is flanked by coarse coral shingle beaches; the northern point is buried in large coral boulders. Miledu, Tukandu, and Marandu are all steep to, and characterized by a belt of large boulders on the eastern face. The finest boulders are on Tukandu (Pl. 53), towards the southeastern extremity and on the eastern point of Marandu. The reaches of boulders are separated by sand or coarse shingle beaches. On the western sides the islands are bordered by high and steep sand beaches.

\section{Ihavandiffulu.}

Plates 1, 2; 8 a, figs. 1,$8 ; 54,55$, fig. 1.

Ihavandiffułu (Pls. 1, 2), the northernmost atoll of the Maldives, is irregularly rectangular in shape, abont thirteen miles in length, and seven in width; its trend is from southeast in a northwesterly direction. It is separated from Tiladummati by Gallandu Channel, about two and a half miles in width at its narrowest point and with a depth of two hundred and fifty-one fathoms in the centre. A sharp ridge must connect Ihavandiffulu and Tiladummati, as both to the enst and west are found soundings of over six and seven hundred fathoms (Pl. 1).

- The sonthern horn of Ihavandiffulu is occupied by Digufuri, an elongated, pear-shaped reef, with wide flats at the two extremities enclosing a shallow lagoon, occupying the central area of the reef flat. The outer rim of this flat is edged by a low wall of small coral boulders like that which fringes Makunudu. A few ill-defined sand-bars rise on the outer belt of the northern face of the reef flat towards Ihavandu Island.

North of Digufuri the concave western face of Ihavandiffulu is bordered by a reef flat from one to two miles in width; its northwestern horn sweeps eastwardly to form the northern boundary of the atoll. On the sea face of the western reef flat extends a long chain of narrow islands and islets set. back somewhat from the outer edge of the reef flat (Pl. 54, fig. 2). The western faces of these islands and islets are bordered with sand or coarse shingle beaches with short reaches of beach rock at the base of the beaches. A belt or low wall of small, weathered, angular boulders similar to that of 
Digufuri extends away to the northward on the outer rim of the western reef flat. The vegetation on the islands of the western reef flat of Ihavandiffulu is meagre, but those in the interior as well as on the northeastern face of the atoll are covered with a flourishing outer belt of bushes surrounding imner clumps of taller forest trees.

A belt of small boulders skirts the edge of the narrow reef flat of the northern point of Ihavandu Island; a steep, high, coarse coral shingle beach mixed with small boulders has at times been driven through the onter belt of bushes between the base of the trees to a height of more than twelve or thirteen feet.

We examined Manafur as a type of the islands in the central part of Ihavandiffulu; they are all steep to, with small reef flats. The eastern half of the northern face of Thavandiffulu is open, with a single small lagoon reef island (Wagaru) near the centre of the northern side.

On the northeastern face of the atoll are three small islands, steep to with small reef flats, and towards the northeastern horn a larger island, Uleguma, also steep to, and over two miles in length. The southern part of the northeast face ends in a long lagoon reef flat, at the extremities of which are two islands of considerable size, Muladu and Gumati; the gap between them (Pl. 54, fig. 1) is apparently closing, as the low vegetation of the inner extremities clearly indicates their recent origin. The long sand spit forming the northern extension of Muladu with its low vegetation and ending with small distinct tufts of bushes indicates elearly the extent of the recent addition to the island. The corresponding spit of the southern part of Gumati is much shorter. The small reef flat forming the northern horn of Gumati is nearly covered by small boulders.

The southern point of Beranundu is formed by a high, steep sand beach, while its northem point (P1.55, fig. 1) and the southern point of Muladu are high, steep, coarse coral shingle beaches, with heaps of boulders at the base.

The passes on the northeast face of Ihavandiffulu are wide and deep; those of the northern face are as wide, but of a less deptli. The western pass through which we entered the atoll is more than sixteen fathoms in depth and fully a mile and a quarter wide. On the sontheast fice, for a 
distance of over six miles, the small island of Galandu and a few coral heads alone bar the free circulation from the eastward. We passed out of Ihavandiffulu atoll through the deep pass to the south of Murdu. The deepest part of the lagoon of Thavandiffulu is thirty-one fathoms; the majority of the soundings are between twenty and twenty-six fathoms, and in the northwestern part of the atoll they are considerably less, from twelve to sixteen fathoms.

\section{Toddu.}

Plates 1, 4.

Toddu is a small steep-to island to the north of Rasdı Atoll, about a mile and a half in length by a mile in width, rising on the western edge of the plateau extending to the west of North Male, and which unites Toddu, Rasdu, and Ari. The greatest depth between Toddu and Rasdu is one hundred and fifty fathoms. There are no soundings to the north of Toddu. The island of Toddu is surrounded by a narrow reef flat somewhat wider on the western face; it resembles in every respect the larger steep-to islands of the interior or outer faces of the larger Maldivian groups.

We did not visit either Toddu or Rasdu.

\section{Rasdu.}

Plates 1, 4.

Rasdu Atoll resembles in a general way Wataru Reef; it is irregularly cireular in outline, somewhat more than four miles in diameter. The western face is formed by a continuous reef flat. At each extremity of the eastern face of the atoll is found a faro and two small islands. The southern pass is divided by an islet; its western side is occupied by a small island. The greatest depth of the atoll is twenty fathoms. The lagoon is studded with coral heads, and a belt of rings and banks extends diagonally across it in a northwesterly direction from the southern pass.

Rasdu is separated from the northern part of Ari by a channel four and a half miles wide with a greatest depth of one hundred and forty fathoms. 


\section{Ari.}

Plates 1, 4; 8b, figs. 12, 14; 8r, fig. 25: 55, fiy. 2; 56, 57, 58, fig. 2.

No island group in the Maldives has the characteristic features of the archipelago so well marked as Ari. We may call it a great agglomeration of banks and faros over an elliptical area fifty miles in length and fifteen in width (Pl. 4). The western face of the group is flanked by comparatively few faros, some of considerable size, over five miles in length. The eastern face, on the contrary, is bounded by a great number of small faros and banks, and towards the north the northeast face of Ari is quite open. Within this great area are dotted nearly two hundred lagoon reefs (faros) and banks, many of them, especially in the northern half, over two miles in length. A number of the lagoon reefs are comnected with islands. Over twenty islands and islets on banks varying in size from a few yards in length to more than two miles are scattered irregularly through the central part of Ari. There are but few islands on the faros of the west face, while on the east face there are islands on nearly every lagoon reef or bank. Some of the islands are a mile in length.

The greatest depth of Ari is forty-three fathoms. The majority of the sommdings within the group averages thirty fathoms.

Many of the faros on the east face of Ari are most irregular in outline; they all tail westward, ${ }^{1}$ and are separited by deep channels with from twenty to thirty fathoms in the centre of the passes. Shingle or large coral boulders flank the eastem spits of many of the faros, and the surface of the rims of the lagoon reefs is covered with patches of flourishing corals.

To the north of Midu a pear-shaped faro extends westward for nearly two miles, with two islands on the eastern and southerm part of the rim, which encloses a large lagoon with a depth of seven fathoms. Midu itself is a large island occupying nearly the whole of the reef flat upon which it has arisen.

\footnotetext{
1 The trend and shape of the islands on the east faces of the northern groups show in general the dircction in which the sand is driven from the sea fares to the westward, both by currents and by the prevailing winds. The same effect ean be traced on the faros and islands of the interior of the larger basins and on their western or other faces.
} 
As we steamed along the eastern face of Ari, we could see that the eastern part of Ari was filled with numerous diminutive banks and faros and coral heads which render its navigation dangerous (Pl. 4). We entered Ari north of Digura by a pass (Pl. 55, fig. 2) nearly two miles wide. To the north of the pass the faros are closely packed and irregular in shape, - dumb-bell, comma, circular, or crescentic in outline. Dugati, immediately north of the pass, is a crescent-shaped faro enclosing a lagoon of from five to seventeen fathoms and edged on the western face by a similar crescent made up of a line of small banks, the southern horn of which is flanked by a belt of corals awash. The southem face of Ari is flanked by two large reef flats separated by Ariadu, a large irregularly circular island with deep passes on either side.

On the eastern part of the western reef flat are four islands, the largest of which is Mamigeli (Pl. 56). Three lagoons are enclosed within the flat, the two largest on the western part of the reef flat.

Digura Island is nearly two miles in length; it flanks the eastern rim of a wide lagoon with from four to seven fathoms of water. The northern part of Digura Faro is more than two miles wide. On the western part of the same lagoon reef flat are Didu and two other islands. 'To the south of Digura Island a line of small islets extends towards Kurafuri the gaps between the islets are nerrly filled by sand spits and bars which will eventually unite the two larger islands. On the outer face of Digura a long line of large black boulders crops up on the edge of the enstern rim flat; on its western slope a magnificent belt of corals extends from twelve fathoms to the surface; they extend eastward along the elge of the rim flat far towards the lagoon slope. The edge of the westem reef flat is quite irregular; at a short distance from the outer edge huge coral kmolls rise nearly to the surface from a depth of twelve to fifteen fathoms, forming a series of submarine buttresses more or less connected with the corals growing on the western face. At many points they have thus materially widened the area of the rim flat on the west of Digura lagoon. We found only a few patches of corals on the bottom or slopes of the rim of the lagoon; nowhere perhaps have we seen a finer example of the great development of corals on the so-called lagoon face of the land rim of an atoll, as at Digura. 
Off the western face of Digura we found only fine and coarse coral sand, but none of the sticky ooze so characteristic of the bottom of the lagoons of the Pacific atolls. To the north of our anchorage off Didu we saw a large, most regularly elliptical faro fully a mile in length. Immediately to the west of Digura Pass are a number of large faros of various shapes, with very regular rim flats and some with lagoons of considerable depth. Some of the banks we passed have no velus indicated on the chart; it is difficult to say that this is an error of the survey, or betokens a change, as is suggested by Mr. Gardiner for North and Sonth Nilandu. ${ }^{2}$ In one of the faros we find from six to seventeen fathoms, in another from four to ten; another has a greatest depth of nine, and several have depths of five to six fathoms. We did not check these somndings, yet we conld see that these faros had undergone only slight changes since they were surveyed in 1834. In areas protecter from the action of the monsoons a faro with a deep lagoon and well-submerged rim must ehange slowly; its rim inereases very gradually in width and height, and its lagoon fills at a very insignificant rate.

The horn of the eastern face of the south pass into Ari, as well as of the western face of the pass, is edged with large boulders, and a mass of coral rubble is thrown up on the flats of Ariadu, on the southern face of the island.

To the west of Mamigeli a number of sand-bars have been thrown up on the south side of the eastern, irregularly shaped lagoon of the faro. The northern rim of the lagoon is a mere narrow flat; its slope and summit are covered with a magnificent growth of corals. The western islands of Mamigeli Faro are separated from the terninal lagoons by a wide green flat covered with from two to six feet of water. The northern horn of this faro is sharp, and is separated by a pass with not more than six fathoms from the faro to the north of it, the first link of the chain of large faros flanking the westem face of Ari; six of these are at least four miles in length; they are quite irregular in outline.

At the northivest angle of Ari is Matiwari, an irregularly shaped faro resembling Dugati, at the southeast angle of Ari, only the reef flat area is more extensive in the northern faro; like the southern faro it seems 
to have been formed by the coalescence of smaller faros or patches, once separated by comparatively shallow water. The depth of the passes between the faros of the west face of Ari is not as great as on the eastern, where the average depth of the narrow passes is fully twenty-four fathoms. On the western face are several passes with not more than from six to fifteen fathoms. The lagoons of the faros of the west face of Ari are many of them quite deep; ten, fourteen, fifteen, sixteen fathoms are the depths indicaterl on the charts. These faros are also characterized by the great width of the western rim flats of the lagoons. Throughout the sonthern part of Ari are a number of small and ineipient faros in all stages of development. On the little island which divides the second southem pass on the west face of Ari, the small reef flat is covered with great slabs of beach rock. ${ }^{1}$

About five miles to the southeast of Mandu Faro and about three miles and a half south of Furadu, is a large elliptical ring over two miles in length (Pl. 57, fig. 1), with a fairly wooded island on the southern rim flat and a small sand bank on the western face of the rim, which is nearly all awash.

The faros in this part of Ari have been somewhat modified since they were surveyed by Captain Moresby. On the rims of several we find islets and ishands, or sand-bars and banks, which did not exist at the time of the survey. The changes in this part of the group may be due to the position of the faros exposed to the action of the northeast and specially the sonthwest monsoon in that area of Ari. The existence of the lines of boulders on the outer rims of the faros of the southern and western faces of Ari shows the extent of the action of the sontbrest monsoon on the faces of the faros exposed to them.

Abont a mile and a half south of Furadu there is a circular faro (Pl. 57, fig. 2) fully a mile in diameter with a lagoon evidently deepest at the enstern extremity, where it is of a dark blue color, and shallower, of a greenish-blue tint, towards the western end. The lagoon is surrounded by a wide greenish rim of uniform width, flanked with fine patches of corals on

I Gardiner (loc. cit., p. 341) has given an excellent account of the formation of terraces of beach sandstonc, off a sand beach; sandstone beach rock is not necessarily, as is stated by him (loc. cit., p. 342), formed on a beach, to a large extent protected from the heavy ocean rollers, or the waves within a lagoon. Among other cases in the Pacitic coral reefs (Mem. Mus. Comp. Zoöl., Vol. XXVIII.) where this is not the case, I migbt mention especially the beach rock on the east face of Nanuku Luevu in Fiji (Pl. 106, A. Agassiz, Bull. M. C. Z., XXXIII.). 
the outer edge; the rim is awash on the northern face where sand is accumulating on the rim flat.

Furadu (Pl. 58, fig. 2), a small island covered entirely with low atoll regetation, is flanked with steep sand beaches and a narrow reef flat. To the east and north of Furadu, a number of large rings are found, one of which is nearly four miles in length. On the south face of Ari a heavy swell coming from the southwest was breaking hard upon the outer edge of the reef flats. The onter face of the reef flats of the southern face of Ari was everywhere lined with fine patches of corals.

The northern part of Ari is not well defined; for a stretch of nearly twelve miles it is open to the northeast; this long stretch is only broken by one large faro, two much smaller ones, and a few diminutive banks, cropping up at about the thirty-fathom line. The northern parts of Ari and of North Malosmadulu have the open character of Tiladummati and Miladumnadulu; they illustrate the passage between the very open groups to those that are more closed, like North Male and the central groups of the Maldives.

\section{North Nilandu.}

\section{Plutes 1, 4. 5: 86, fig. 14: 59-61; 78, fig. 1 .}

The faros in the interior of North Nilandu are large (Pl. 5), some of them a mile and a half in diameter. They are principally in the central part of the group; only a few are near the south and north faces.

The outer rim of North Nilandu is made up of comparatively few large faros, more numerous on the east face than on the west, of an irregularly elliptical shape, enclosing extensive lagoons; wide and deep passes separate the faros. The principal islands on the eastern face of the outer rim are small, with four large wooded islands in the interior of the group. The largest of the inner islands is Biladu; it is well wooded, about a mile inside of the pass separating the faros of Adago and Magudu, near the southern part of the east face of North Nilandu; it is well seen from the sea, across the outer rim of faros. North Nilandı is nearly circular; its greatest length is seventeen miles; the western face being slightly eoneave; 
it is separated from South Nilandu by a channel of three miles and a half in width, with a greatest depth of two hundred and thirty-five fathoms in the centre. ${ }^{1}$ The greatest depth of North Nilandu is thirty-five fathoms, the soundings in general vary from twenty-four to thirty fathoms.

The flat-topped banks we passed all have velus, although the rim is indieated only on two of the banks. Mr. Gardiner has called attention to this defect in the charts of both North and South Nilandu. ${ }^{2}$ He thinks that their absence on the charts proves their formation by solution since the days of Moresby, as in other atolls, their existence is always correctly indieated on the charts. It is difficult to decide this, as the original eharts of Moresby are not accessible. I would also call attention to the same defect in the ehart of Ari, where some of the banks with velus are drawn merely as flat-topped banks with an outer belt of growing corals. None of the imner banks have disappeared, on the contrary, Mr. Gardiner speaks of finding six meharted shoals in the southern part of North Nilandu $;^{3}$ according to him this wonld indicate a rather unimportant action by solution on the inner banks in both North and South Nilandu. Mr. Gardiner's figures of North and South Nilandu do not strike me as indieating the decreased breadtl 1 of the lagoon reefs of the outer rim, upon which he lays great stress. Some of the velus of the outer lagoon reefs had evidently increased in size, but as I lave stated (page 62) this is not necessarily due to solution.

The faros of the east face of North Nilandu enelose large lagoons of considerable depth, varying from six to ten fathoms. There are only three islands of any size on these faros; the others, six in number, are but diminutive islets on the horns of the faros. The western face of North Nilandu is flanked by five faros, all with large and deep lagoons. The central, the largest faro. las, according to the Admiralty Chart, five lagoons, in two rows; Mr. Gardiner ${ }^{4}$ shows three on his figure, its eastern edge flanked by coral spits forming cusps extending as small bays to the eastward, similar to the bays formed by the eusps of the faro sonth of Akirifuri on the west face of North Male. There is only one small island on the western face of North Nilandu.

1 According to the soundings of Mr. Gardiner, loc. cit., p. 405.

8 They are not shown in his Figure 105, page 405, loc. cit.
2 Loc. cit., p. 405, fig. 105.

4 Loc. cit., p. 405 , fig. 105 . 
The depth in the passes between the faros on both sides of North Nilandu clearly indicate here and there the greater elevation of parts of the outer rim of the plateau than the central basin.

On the flat of the northeast face of Farna (Pl. 59) flanking the pass separating it from the faro to the north, a large coral boulder has been thrown ıp; the flat of the southeast horn is covered by similar but smaller boulders.

On the faro to the sonth of Farna (PI. 78, fig. 1) a well-wooded islet occupies the western spit of the rin; the eastern face is edged by patches of coral boulders. On the eastern edge of Hekara, the next faro (Pl.60, fig. 1), the coral boulders are thrown up in larger bodies, and on the eastern edge of the faro flat to the south of Hekara runs a long line of angular coral boulders, pitted, honeycombed, and undercut. The eastern edges of the faros of North Nilindu are all covered with large patehes of corals extending well westward on the rims towards the enclosed lagroons. The edge of the southern face of the pass south of Hekara is also flanked by a line of rounded large coral boulders, mainly masses of Porites, pitted, loneycombed, and many of them undercut as well as on the sea face spit of Feartu. The sea face of the bushy islet occupying the northern extremity of this faro is flanked by a coarse shingle beach, as is also the beach on the east spit of Feartı (Pl. 61, fig. 1).

'The greater part of the east face of Mawafuri (PI. 61, fig. 2) is edged by a belt of angular masses of coral boulders, deeply pitted and honeycombed and undereut, separated by stretches of shingle or smaller rounded boulders, a similar belt of smaller boulders and coarse shingle edges the southern horn of the faro flanking the pass to the south of Mawafuri. The same belt of coral boulders and coarse shingle extends for nearly four miles on the sea face. These lines of coral boulders thrown ip on the rim flats of the eastern face of North Nilandu indicate the luxuriant growth of corals on the sea face of the faros. These lines of coral boulders are pitted and loneycombed, forming little spires and pinnacles, they remind one only on a small seale of the edges of the great reef flats of Australia with their belt of horse heads. The horn forming the south face of Adago is flanked by a similar belt of small horse heads pitted, honeycombed, and deeply undereut, as is the eastern face of Magudu. 
In none of the groups of the Maldives do we find the great well-defined reef platforms which are so characteristic a feature of the atolls of the Pacific. There the islands have in many cases been cut out and denuded from the higher parts of the underlying reef platforms, while in the Maldives the islands have merely been washed up as coral sand and deposited by the drift, the winds and waves, on the rims of the faros or of the diminutive flats. The surface of these is not always made up of recent movable sand, when corals have spread upon them, they lave become covered by a recent reef rock and with loose masses of corals cemented by Nullipores and coral sand.

\section{South Nilandu.}

Plates 1,$5 ; 87$, figs. 18,$17 ; 63.68,64$, fig. 2; 78, fig. 2.

In South Nilandu (Pl. 5) the western and eastern faces rum north and south; the northeru and southern faces are rounded; its greatest length is about twenty-two miles, and the width thirteen miles.

The banks and faros of South Nilandn are fairly uniformly distributed over the area of the group, although the larger faros and banks are situated in the northern part. The onter land rim of Sonth Nilandu is made up of extensive faros and reef flats. The reef flat forming the southwest face of the group is over twelve miles in length. ${ }^{1}$ 'The entrances to the enclosed basin of South Nilandu are deep and wide, several of them over two miles across. Only a few islands oceur on the southwest and northwest face of South Nilandu, the principal islands and islets being on its east face; there

J The Admiralty Chart of South Nilandu does not show any differenee in the indistinet velu of the sonthwestern reef flat from that sketched by Mr. Gardiner on Fignre 105, which has left, as he says, "a series of isolated reef masses, parts of the original great breakwater." Mr. Gardiner says that the changes he observed in both South and North Nilandu were merely local, and that within the lagoons no changes in depths were found.

The shoal indieated by Mr. Gardiner in the pass north of Maimbudu may be an ontgrowth of the reef Hat, as are probably those he indicates south of Feartu in North Nilandu; they are perhaps indicated on the Admiralty Chart, only more to the westward.

Mr. Gardiner* indicates a smaller number of new velus on the inner banks and on the outer lagoon reef flats of South Nilandu than in North Nilanulu; only one relu is adderl on one of the flats of the eastern face, while he potes ehanges in nearly all the lagoon reefs of the southern part of the east face of North Nilandn.

* Loc. cil., fig. 105, p. 405 . 
are a number of large and well-wooded islands in the northern and southern part of the central area. South Nilandu is somewhat deeper than North Nilandu, its greatest depth being thirty-nine fathoms. In both North and South Nilandu the general depth is about thirty fathoms, with many soundings over thirty-five fathoms.

The northern and northwestern faces of South Nilandu (Pl. 5) are flanked with large rectangular faros with from five to nine fathoms in the lagroons. The southern part of the west face is flanked by a narow bowshaped reef flat, enclosing a small lagoon at the northern extremity and studded with a few islands near the sonthern part. A narrow belt of water from six to ten fathoms in depth is partly shut off from the waters to the eastward by a series of disconnected coral banks ruming parallel to the outer reef flat. A similar long reef flat extends along the southeastern face of South Nilandu. It encloses a long narrow lagoon; it is diffienlt to decide whether this lagoon has been formed by a series of independent coral patches similar to those off the reef flat on the western face of South Nilandu, which have gradually joined as they came to the surface and have formed the western rim of the lagoon, or if the rim lhas grown up along its whole length from the surface of the South Nilandu platean, as have the small faros of the interior of the groups of the Maldives.

We entered South Nilandu through the wide pass between Madali and Huludali. The island of Huludali is on the northwest face of a large faro; its sea face is flanked by a belt of boulders and coarse shingle. The rim of the south horn of Madali is flanked by a narrow belt of coral boulders and coarse shingle, and the southern face of the island is formed by a steep shingle beach.

The Jewellers Islands (Pl. 7S, fig. 2), the most important of the inner islands of Sontl Nilandu, are three large well-wooded islands with steep coral sand beaches and short lines of boulders on the south faces of the reef flats surrounding them. Middle Jeweller Island tails out to the westward, forming a small reef flat enclosing a small lagoon. To the west of the same island is fomd a small faro with a diminutive and shallow lagoon, a mere slit in the flat; whenever this becomes filled by sand, it will be elinnged into a sand flat. 
On our way to the east face, across South Nilandu, we passed four large faros; they presented no special features of interest. The number of large well-wooded islands found in the northern part of Sonth Nilandu is one of its marked features. To the south of our track we passed a low sand bank covered with a few bushes, rising on the edge of a faro with a most diminutive lagoon; it forms the beginning of a larger island, which when the lagoon has been filled will cover the whole sand flat thus formed. We then came upon a large flat with a sand-bar and withont any trace of vegetation, and next upon a small faro with a narrow rim enclosing a deep lagoon with an islet on the eastern rim. The northern part of the east face of South Nilandu is flanked by rectangular faros with lagoons of from four to seven fathoms in depth.

With two exceptions the passes separating the outer faros of South Nilandu are deep, over twenty fathoms. We passed out of South Nilandu, south of Konipafuri, and made for the southern extremity of Mulaku. Male Faro, the faro to the south of Konipafuri, is marked by the great width of its reef flat.

When coming north from Kolumadulu, we examined the southern part of the east face of South Nilandu (Pls. 62, 63, 64, fig. 2), from Maimbudu, the faro forming the southeast angle of South Nilandu. In the centre of the faro lies a large lagoon with from three to five fathoms; each extremity is occupied by an island. To the north on the east face follows a smaller faro with a small lagoon to the west of Wani Island. The sea face of the faro is edged by a boulder belt. A similar belt crops out along the sea face of the faros of the eastern side of South Nilandu. 'The beaches of the islands are steep, of coarse shingle, separating an occasional reach of coral sand. The sea is encroaching on the islands of the east face. We passed many cocoanut-trees lying on the beach, and here and there a palm boulder, if I may so call the elump of roots of cocoanuts left occasionally on the reef flats and coral sand beaches.

North of Kandimas (Pls.62, fig. 2; 63, 64, fig. 2), on the next reef flat to the north, we find ontliers of coral reef rock between the beaches of the islands and the boulder belt, - ontliers which have been undercut and are deeply pitted, eroded, and honeycombed, and rise slightly above the general 
level of the surrounding reef flats. To the north of Kandimas Island also begins the narrow lagroon which extends nearly the whole length of that reef flat for a ristance of about six miles. 'The inner rim of the liggoon is much narrower than the outer sea face rim flat, the greater part of which is edged by a boulder belt. Great patches of corals are scattered on the sea face of the reef flat, and often extend well across the onter lim towards the lagoon of the faro. This long faro is separated from Huluwa Island (Pl. 62, fig. I) by an angular faro with a long spit at the southwest lom, on which a coarse shingle beach and heaps of boulders have been thrown up. The limits of the rim of this faro are well defined by the light green belt surrounding the lagoon. Reddish Nullipores cover many of the boulders forming the outer fringing belt of the faro.

The many gaps between the numerous small islets and islands which dot the east face of Sonth Nilandu afford an excellent opportunity to study the formation of the islets, their change into small islands, and the gradual passage into larger islands by the coalescence and junction of the sand spits and sand-bars of adjoining islets and islands.

\section{South Male.}

Plates 1, 4: 81, figs. 12, $16 ; 8 c$, figs. 19, $27: 79$, fig. 2.

The structure of South Male (Pl. 4) resembles in a general way that of North Male; it is smaller, elliptical, and its outlines defined by a greater number of reef flats and fewer faros. There are few rings within the central basin; the banks are more numerous than in North Male, and only five small islands in the central area.

South Male has a greatest length of nineteen miles, and eleven miles in width towards the northern extremity. It is separated from North Male by Wadu Channel, not more than two and a cuarter miles in width and a depth of about two humled and fifty fathoms, and from Felidu to the south by Fulidu Chamel, abont seven miles in width with three hundred and seventyfour fathoms in the centre of the channel. South Male is as a whole shoaler than North Male; its greatest depth is thirty-two fathoms, but by far the majority of the soundings are between twenty and twenty-seven fathoms. 
Along the east face of South Male, north of Hutekoln, nothing of special interest is to be seen on the extensive wide reef flat which forms the southeast horn of South Male. The reef flat is shallow, with the exception of a belt of deeper water, ruming diagonally across it south of Haru Hura. The islands on this flat are covered with low vegetation. On the outer edge of Mafuri, the reef flat to the north of Guradu, are heaps of small boulders, and great patches of corals cover the rim of the flat. A goorl part of the island of Mafuri (Pl. 79, fig. 2) is wasting; what once formed its northern extremity is now an islet with fallen cocoannt-trees covering the intervening reef flat. The island and islet on the faro to the south of Gurn are flanked with shingle beaches near the onter edge of the faro, passing into sand beaches close to the inner edge. Large heaps of shingle are piled on the outer edge of the reef flat of Guru.

The lagoon of the large faro north of Guru on the east face is remarkable for its great depth; it is not less thin nineteen fathoms, fully as deep as that of Dureadu in the central part of the southern half of Miladummadulu. The faros of the western face of South Male present no new feature, umless it be the irregularity of their outlines.

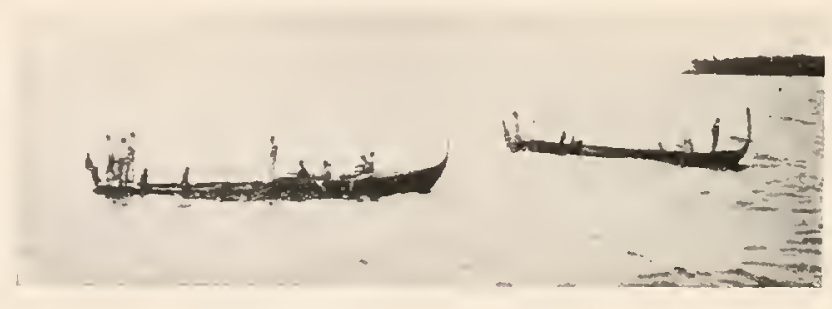

Native Boats off South Male.

Felidu.

Plutes 1, 4. 5; $s$ b, figs. 15, 16 .

Felidu (Pl. 5) is the most irregular in outline of the Maldive groups: it is somewhat boot-shaped, the foot forming a long projection to the eastward, bounded by a narrow reef flat with three small islands at the enstern horn. Along the southern face and eastern extremity runs a continuous narrow 
reef flat with four narrow lagroons, in one of which near the eastern horn is found eleven fathoms of water. Along the northern face of the eastern part of Felidu four elongated reef flats extend, separated by narrow passes. One of the flats is an elliptical faro with seven fathoms in its lagoon.

The faros on the southwestern and eastern face of Felidu are most irregular in shape. In no group have we found such irregular edges to the inner face of the reef flats as on the northwest face of Feliclu. Off each flat runs a series of cusps, spits, and points, similar to those south of Akirifuri on the northwest face of North Male. Some of these extend a considerable distance into the lagoon. They form bays and hooks enclosing parts of the adjoining waters, some of them of considerable depth varying from three to twelve fathoms. It is probable that the eastern extension of the narrow reef flat forming the foot of Felidu was originally developed from a series of such cusps and spits growing on a shallow part of the Felidu plateau, and uniting small faros more or less elliptieal, once separated by shallow passes.

The faros of the western and eastern faces of Felidu are separated by comparatively narrow and deep passes. There are no less than ten of these along the southwestern face in a distance of about twelve miles. The western part of Felidu is dotted with rings, faros, banks, and heads; several of the rings are nearly a mile in diameter. There are only four islands and islets in the central part of Felidu; the eastern projection of Felidu is nearly elear of obstructions. The greatest depth of Felidu is forty-one fathoms in the sontheastern part; the majority of the soundings range between twenty and thirty fathoms.

Rakidu Island is on the east of the pass by which we entered Felidu; to the east of the island is another very narrow pass, a long spit makes out from the westem extremity of Rakidu enclosing a small lagoon. On the west side of the pass a small islet has been formed by the accumulation of sand behind the heaps of shingle and of boulders thrown up on the eastern edge of the reef flat of the large faro on the west side of Rakidu Pass. As far as could be seen, similar heaps of shingle and of boulders flank the outer edge of the west face of the faros forming the southwest face of Felidu. 
The western edges of the faros are bordered with shingle jetties rumning at right angles to the sea face; some of them terminate in small sand islets. The island of Rakidu is built up of two adjacent islands, which have become united; the old gap once separating the two islets is still plainly visible when seen from the centre of the channel. On the western spit of Rakidu, a number of cocoanut-trees have fallen on the reef flat and near the beach; the position of the bushes and vegetation covering other parts of the shore of the island indicates a certain amount of wasting away of the western and northwestern portion of the island.

Steaming to the eastward inside of Felidu, we skirted the reef flat to the east of Rakidu, along this extends a very narrow lagoon not shown on the chart, unless it be the extension of the long spit running into the lagoon, and indicated on the chart about a mile west of Buri Hura Island. The whole length of the edge of the western rim of this narrow lagoon is covered by a long line of small yellow angular boulders, greatly pitted, honeycombed, and underent, an ontlier of reef rock rising somewhat above the surrounding reef flat.

To the north of the spit rises a well-defined faro about a mile in diameter with a comparatively deep lagoon, judging by its color. An islet with low bushes lies on its eastern rim, and on the northern rim a patch of reef rock undercut, pitted, and honeycombed indicates that this faro is probably of greater age than many central faros we have thus far seen.

The northern face of Buri Hura is also wasting away. Fallen cocoanuttrees are seen on the beaches and reef flats adjoining the island. To the west of Buri Hura Island a large ontlying block of honeycombed reef rock rises from the inner edge of the reef flat; on the southern sea face of Felidu a long line of angular boulders forming a long low wall of perhaps eighteen inches in height runs along the outer edge of the reef flat on both sides of Buri Hura. This belt of coral bonlders is undercut, pitted, and honeycombed, and greatly resembles the patches of reef rock we saw on the inner face of the reef flat.

While crossing the atoll of Felidu from Buri Hura to Kendu, we passed to the eastward of a bank covered with angular boulders of reef rock, rising in the centre to a height of about eighteen inches. The boulders are 
apparently identical with the reef rock forming the boulder beit off Buri Hura. There is evidence of a more general erosion at Felidu than in any other group of the Maldives.

There is a large faro with a wide rim on the eastern face of Felidu to the south of Keadu; the chart indicates a depth of four fathoms in the lagoon. Keadu and Felidu are two well-wooded islands; to the north on the eastern face of Felidu, Tinadu and Alimata are the only islands on the outer faros. The passes between the larger faros of the east face are usually divided by long sand banks, leaving only narrow but deep passes on each side, judging from the deep blue color of the central part of the pass. These bars are well indicated on the chart; the sand-bars awash are perhaps larger; otherwise no important change seems to have taken place on that part of the east face of Felidu since 1836. Passing out of Felidu between two faros halfway between Tinadu and Alimata we found the outer horns of the faces of the pass distinetly marked by piles of angular boulders undercut, pitted, and eroded. On the outer rims of the faros of the eastern face sandbars often took the place of the boulder belt, while to the north of the pass above mentioned, the reef rock patches and shingle heaps continue on parts of the outer edge of the reef flats and faros. Extensive patches of corals also dot the outer rims of the faros. The northern passes of the eastern face, as seen skirting the outer edgre, stand out as well-marked, inverted funnel-shaped entrances, with dark blue bands indicating the deep parts of the chamel. The outer beaches of Alimata are steep coral sand beaches, with but few bonlders on the outer edge of the reef flat. The lagoons of the two large faros to the north of Alimata have depths of five and seven fathoms. Digeri Island is situated just inside of the pass separating these faros.

While there are a great many passes leading into Felidu, yet no part of its periphery is open. The widest passes are less than a mile, the majority being narrow cuts of considerable depth, often more than twenty fathoms. 


\section{Wataru Reef.}

Plates 1,$5 ; 8 b$, fig. $15 ; 58$, fig. 1 .

Wataru Reef (Pl. 5) is a large isolated lagoon reef (atoll) rising upon a small steep plateau lying in the centre of the channel separating Mulaku from Felidı. The northern part of the channel between Wataru and Felidı is two miles, the southern between Wataru and Mulaku, two miles and a lualf wide. Wataru is triangular in shape with rounded corners, its greatest length a little less than four miles. The rim reef flat is nearly awash at several points; its position is elearly indicated by the color of the water. There is a very narrow entrance into the lagoon at the southern extremity, flanked on each side by low bushy islets (Pl. 5S, fig. 1). The outer erlge of the rim flat is covered by a belt of coral patches; here and there a patch of coral boulders cropped up along the east face of IVataru, as well as at the base of the steep shingle beach flanking the islets at the entrance of the lagoon.

The northeast horn of Wataru is edged with angular houlders greatly pitted and honeycombed; they form a fine sweep as they follow the curve of the horn with the monsoon sea breaking upon them. As is seen from its deep blue color, the lagoon of Wataru Reef is of considerable deptli; twentyone fathoms are indicated on the chart.

We passed the reef at high tide; at low water when the rim of the faro is nearly awash it must be one of the best-defined faros of the Maldives.

\section{Mulaku.}

Plates 1, $5: 8 b$, figs. $18,15,18 ; 64$, fig. $1: 65$.

Mulaku (Pl.5) is irregularly triangular; its westem face runs dne north and south for a distance of twenty-five miles. The greatest width east and west is about fifteen miles; it is flanked by thirteen small reef flats and faros of irregular elliptical shape, on only two of which are islets.

A number of somdings in the central basin of Mulaku range from forty to forty-two fathouns the greater number of the soundings vary from twenty-five to thirty-five fathoms. 
Mulaku and Felidu resemble more the groups forming the single line like Kolumadulu and Haddunmati than the groups forming parts of the double chain, like the Nilandus to the west and the Males to the north, though there are more faros on the outer faces of the northern gromps than in the southern atolls. In many cases, especially in the southern groups, it is difficult to determine the mode of formation of the faros and their enclosed lagoons, and to decide whether they are formed, as seems to be the case in the southeru part of the western reef of South Nilandu, by the coalescence of numerous pitches growing up parallel to the inner face of the reef flat, and enclosing thus a long lagoon, as in the long reef flat on the east face of South Nilandu, and as may have been the case also in the formation of the lagoons within the long narrow reef flats on the eastern face of Mulaku; or by the junction of independent faros.

There are few rings within the area of Mulaku, all of a small size, and only one inner island, Mulaku, facing the central pass of the east face of the group, but a multitude of small banks, mainly on the western side. The western face of Mulaku is flanked by a number of small irregnlarly shaped faros enclosing shallow lagoons; some of them are crescentic with widely separated horms; the faros forming the northern and northeastern faces are larger. The east face is flanked by two great reef flats; the northem one encloses two lagoons near the broad eastern horn, with six fathoms of water and a smaller one near its southern extremity. On the southern reef flat there are three long lagoons with six fathoms of water. The eastern faros are studded with chains of islands constituting the principal land of Mulaku, as there are only a comple of small iklands on the faros of the northeastern and western face. The northeastern face is bounded by four reef flats with long spits at the angles trending west.

Mulaku is interesting as being the northermmost of the Maldive groups, which to some extent assumes the appearance of some of the larger atolls of the Paumotus. This is shown by the land rim of the eastern face, which consists of only two long reef flats, enclosing, it is true, lagoons, as when the faros are numerous and small. Yet it is possible that these large faros lave, as in the case of the larger flats of South Nilandu, grown up from the coalescence of adjacent small reef patches. and not from the regular upward 
growth of an elongated ring of corals enclosing an interior lagoon. The great land rims of the Paumotus, however, have beell cut down from ledges once of a greater height, upon the outer faces of which corals have grown; while in the Maldives the flats are made up of recent corals which have grown up from the base forming the underlying plateau of the Maldives and have only been slightly elevated.

As we go south from Mulakn the Maldivian character typical of the island groups gradually disappears more and more. A mere glance at the chart shows this conclusively (Pl. 1). Neither Kolnmadulu nor Haddummati would be chosen as typical representatives of Maldive groups with their claracteristic rings and faros; they combine Maldivian features with extensive narrow reef flats, characteristic of Pacific atoll-lagoon reefs. The northeast horn of Haddunmati reminds us of the eastem horn of Arlmo in the Marshall Islands. The Maldivian type is still less apparent in Suvadiva and Addu, an atoll on the southernmost plateau of the group, such as might be found either in the Paumotus or the Ellice, Gilbert, and Marshall Islands.

It is true that within the area of Mulaku there are more than one hundred flats and rings, but they are small and do not compare with the characteristic larger, circular, or elliptical, faros, often several miles in length, crowded in North and South Male, Ari, and within the basins of other northęrn groups. The absence of flats and faros within the area of the southern groups is striking in Kolumadulu, still more in Iladdummati and Suvadiva. The aspect of the southern enclosed basins (lagoons) reminds us of such large lagoons as Fakarava and others of the Paumotus, where there are either numerous small islets or only shoals to be seen in the great expanse enclosed within the outer land rim.

The western face of the western faros of Mulaku is edged by stretches of small coral boulders and coarse shingle set in transverse dikes running at right angles across the outer rim of the faros, they are more prominently heaped up on the two sides of the passes separating the faros (Pls. 64, fig. 1; 65, fig. 1). These stretches of bonlders and shingle are largest on the western face of Kureli Faro; they are usually mainly masses of Porites tailing into long sand spits towards the east. When seen entering the pass 
to the north of Kureli Faro, they appear like a series of great parallel furrows thrown up near the outer edge of the rim. Similar ledges of boulders and lines of shingle extend from Kureli to Kolufuri, the southernmost point of Mulaku.

Fine patehes of corals grow on the imner rim flats, and on the sea slope of the outer faces corals must also grow in great abundance, judging from their extension eastward over the onter rim thats and from the mass of coral boulders and coral shingle thrown up as dikes on the sea faces of the faros along the whole western face of Mulaku. The outer edge of the reef flats are discolored by the dark patches of growing corals stretehing to the eastward across the outer rins of the faros.

Kureli Island is on the extremity of the southern faro of the west face of Mulaku, set back a short distance from the western edge of the rim reef flat, flanked by a belt of rough, angular coral boulders forming a low wall of pitted, honeycombed, and undercut masses passing towards the inner face, first into coarse coral shingle and then into coral sand on the east face. The southern face of Kureli Faro (Pl. 65, fig. 2) is edged by a similar wall best seen off the west face of the island itself, indicating a former higher level of Kureli.

We also examined the northern half of the west face of Mulaku; it is bounded by a number of small faros of irregular outline, separated by deep passes. The faces of the passes are usually indicated by heaps of shingle or small boulders or accumulations of sand. Along the sea faces of the faros, shingle or sand jetties project to the eastward.

North of Tuvaru there are no islets on the faros of the west face except on the northern faro, near the northwest horn of Mulaku, where rises a small island flanked by a coral sand beach and covered with low vegetation. Neither this island nor the small wooded island we saw on a sand bank to the eastward are indicated on the charts of 1836 ; they have both been formed since that date. The sonthern extension of the northwestern horn of Mulaku is a narrow reef flat, the western edge of which is crowded with flourishing patches of corals. The western face of the faro to the south is also edged with coral patches. 


\section{Kolumadulu. \\ Plates 1,$5 ; 87$, figs. 17,$18 ; 8 \mathrm{c}$, fig. $20 ; 66$.}

Kolumadulu (Pl. 5) is nearly circular; its greatest diameter from east to west is twenty-nine miles; the north and south dimensions are somewhat less. Its sea faces are Hanked by narrow reef flats, with the exception of the wider flat bounding the southern face from Vaimandu to Hirilandu; on this flat are also some of the larger islands of Kolumadulu. A few islands are scattered on the reef thats of the northeast face, and a long line of islands and islets extends in a southerly direction on the southeast face from Fahala, an island nearly four miles in length, and one of the largest in the Maldives.

Kolnmadulu is deeper than the northern groups; it attains a depth of forty-five fathoms in the central area; the greater number of the soundings are near forty fathoms. ${ }^{1}$ The interior of Kolumadulu is dotted with small banks; they are more numerous in the southern half of the western part of the atoll. 'The only islands in the atoll are near the western face opposite the pass to the south of Kandudu and on a large faro to the eastward of Hirilandu.

The islands of the northern part of the east face of Kolumadulu present no features of special interest; they are fairly covered with low vegetation and edged by steep coral sand beaches. Fahala, one of the larger islands of the Maldives, over three and a half miles in length, is covered with fine vegetation; south of it, on the greater part of the islands of the east face of Kolumadulu, the vegetation consists almost entirely of low reef vegetation similar to the scanty flora of many of the Pacific atolls.

South of Fahala ${ }^{2}$ a number of islands have been thrown up diagonally across the reef flat; the points and beaches of their onter faces are coverer

1 Mr. Gardiner found no changes in the depth of the lagoon of Kolumadulu, and says that in but few of the islands of the outer reef flats did he detect any changes with the exception of a "slight washing away of their seaward faces." * He also speaks of important changes in two of the passages he examined; thicy are not indicated in his Figure 106, p. 407.

Mr. Cooper states that a few of the shoals rejresented on the charts as reaching the surface only existed as mounds well below the low-tide level. $\dagger$

2 The most marked ehanges which have taken plaee in the land rim of Kolumadulu, Mr. Gardiner notes at Fahala; he has observed that the island has become joined to the small island marked on the chart to the nortl of it; in its place is now found a velu, the washing away of its soutbern end. (Loc. cit., p. 407.)

$$
\text { * Loc. cit., p. } 407 .
$$


with coarse shingle. Towards the inner face it gradually passes into smaller and finer shingle and finally into coral sand. The slingle points are often comnected by bars of small boulders or coarse shingle, forming a belt or breakwater on the outer edge of the reef flat. Thus an outer bay is formed, coarse sand is deposited behind the low dam of shingle, it sand-bar soon rises well above the general level of the reef flat, scanty vegetation begins to cover the summit of the bar, and then a crescentshaped or open rectangular island is formed; it eventually becomes filled with sand blown in both from the sea face and the lagoon side. The small independent islands are thus gradually comnected into larger ones, forming perhaps even such a large island as Fahala.

Some instruetive stages of this process of consolidation of the islands occur between Fahala and Diyageli (Pl. 66, fig. 2). In one of the gaps in the immediate vicinity of Fahala rose a mere islet flanked with bushes and sand-bars forming a bridge between the adjacent islands. The east face of Kolumadulu recalls vividly the aspect of the outer rim flats of many of the Marshall and Gilbert Atolls, where the islands form great square bays, often becoming connected on the lagoon face after they have been shut off from the sea by the long line of boulders and shingle forming the breakwater connecting their sea face extremities.

South of the eastern pass dividing the two narrow reef flats which flank the east face of Kolunadulu extends a line of angular coral boulders similar to that on the edge of the northern reef flat; it must be at least three quarters of a mile long and forms a boulder and shingle breakwater on the outer edge of the reef flat connecting two of the islands upon the onter part of the rim flat, distant at least tlree quarters of a mile. On the inner edge of the rim flat rise sand banks, islets, or islands, more or less covered with vegetation, gradually closing the open gap between the inner extremities of the islands first united by the breakwater thrown up on the outer face of the reef flat. One of these breakwaters connecting adjoining islands enclosed a bay nearly two miles in length; the inner face of the bay was Hanked by four small islands with sand spits extending from both extrenities nearly joining them. On the islands of the east face of Kolnmadulı we noticed many Pandanus trees. 
To the nortbeast of Timarafuri the reef flat becomes more than a mile wide. The northern face of Timarafuri Pass is flanked by a wide flat edged with lines of boulders, and Timarafuri Island is edged with a steep beach of coarse coral shingle. The corals on the inner face of the reef flat to the northeast of Timarafuri are far less flourishing than the corresponding belt of corals of the more northern groups. It is perhaps what might be expected in such groups as Kolumaduln, the interior basin of which is comparatively shut off from the outer waters; the outer land rims being more continuous leave only few and narrow openings allowing access to the oceanic currents. Thus a great amount of pelagic food is shut out from the central basins of such groups as Kolumadulu, while in the central and northern groups of the Maldives where the outer land rim is formed of atolls, separated by wide and deep passes, the currents rush in and out with great rapidity.

The larger groups forming the single line of the Maldives from Kolumadulu south to Addu, all have the same characteristics; while the smaller groups on isolated parts of the Maldivian platean, like Rasdu and Toddu to the north of Ari, and Karidu, Wataru Reef, Gaha Faro, have all the characteristics of the smaller faros of Ari and of Male. Some of them, like Gaha Faro, are really only larger faros separated by deeper and wider channels from the adjining groups. In fact, we may consider such great plateaus as the three plateaus of Malosmadulu as one extreme, and islets like Karidu and Fua Mulaku as the other extreme; while plateaus such as Tiladummati and Miladummadulu, where the atolls are separated by wide but shallow passages, are an intermediary stage. On the larger plateaus many small atolls have been formed, while on the smaller plateaus or summits small faros have grown up, resembling more or less Pacific atolls, in accordance with the size and shape of the underlying base.

Nothing we have seen thus far in the Maldives indicates any marked elevation; nowhere do horses of old reef rock flanking the beaches or rising upon the reef flats indicate any considerable amount of erosion. The cxistence of a few pitted and honeycombed and deeply undercut outliers of modern reef rock near the outer rim of some faros, rising perhaps two or three feet above the reef flats, indicates only a very slight elevation in some 
of the Maldive groups, or a long stationary period, during which the faros and atolls of the Maldives have grown to their present condition from the underlying plateau and its secondary elevations.

We examined the south and west faces of Kolumaduln from Kimbudu, one of the easternmost islands on the wide curved reef flat of the faro which forms the south face of Kolumadulu and a part of its western face. The lagoon of this faro extends nearly the whole length of the reef flat; it varies in depth from four to seven fathoms, and is fully a mile wide in places.

The structure of the faces of Kolumadulu is in striking contrast; the northern and eastern are flanked by narrow reef flats. On the small flats of the northern face there is only an occasional island, while on the two long reef flats forming the eastern face runs a nearly continuous line of islands from Falhala to the pass north of Guradu, and then again to Timarafuri on the long and narrow southern reef flat. On the southern face, and on the southern part of the western reef flat, we have a well-developed faro lagoon, as well as faros to the north of the western pass and on the flat which divides the western pass into two passages. So that the eastern face of Kolumadulu (the northernmost of the single line of groups sonth of the central Maldives) assumes the characters of the sonthern atolls, while the western face with its lagoons takes that of the central groups to the north of it. The central part of some of the encircling reefs of Kolumadulu, Haddummati, and Suvadiva is occupied by shallow lagoons or velus. In places they seem to have been formed by inner lines of coral patches growing parallel to the outer reef flats, and enclosing a part of the original rim shoal of the lagoon.

The sea face beaches of the islands on the southern side of Kolumadulu are steep. The vegetation extends close to high-water mark, and in many places the sea washes the base of the trunks of the trees. The outer spits of the islands usually terminate in shingle beaches or patches of small boulders, while the inner beaches become sandy. Many isolated sand bal's and banks are irregularly scattcred over the sonthern reef flat, between the outer edge and the lagoon of the faro. The outer edge of the reef flat is flanked by a belt of coral boulders. 
Kimbudn, the southernmost island of Kolumaduhn, extends nearly to the outer edge of the faro. Its southern point is protected by coarse shingle and boulders, and on both the eastern and westem faces we readily trace the passage of the coarse shingle of the onter point into the fine shingle and coral sand beaches of the island towards the lagoon face of the faro.

The shape of the lagoon of the westem land rim between Kandudu and Weligandu can be traced by its color; it is of a brilliant light blue, passing into the light green belt of shallow water of the extensive reef flat reaching from Weligandu as far north as Kandururi pass. Judging from the absence of colored patches, few corals flourish on the upper parts of the sea face slope of this northern reef flat.

The island to the northeast of Hirilandu, opposite the pass, is on the western face of a large faro, fully two miles in diameter, surrounded by a wide rim enclosing a lagoon with four fathoms of water. 'The northwest point of the island is edged by a prominent boulder belt.

Opposite Naraka we find ontliers of reef rock undereut, pitted, and honeycombed, extending parallel to the outer edge between the island and the boulder belt along the sea face. The sea is encroaching on the island to the soutl of Naraka (Pl. 66, fig. 1). Several cocoanut-trees are lying on the flat, the roots well away from the beach. 'These isolater roots look like coral boulders, and at a distance might readily be mistaken for such. In the northern part of the Maldives we often found such masses of isolated roots, at a distance from the beaches and well ont on the reef flats adjoining the islands. North of Naraka sand-bars and patehes and belts of shingle extend as far as Hirilandu. Some of the shingle belts are mere threads, often ending in small sand bars or banks.

To the south of Hirilandu a narrow curved pateh of corals projects off the lagoon face of the reef flat, and nearly shuts in a small area of the lagoon with twenty-one fathoms of depth. The existence of sneh a spit readily explains the formation of small faros with lagoons of considerable depth. Their growth in a linear direction parallel to the lagoon face of a reef flat would also account for the formation of long lagoons like that extending from Vaimandu nearly to Hirilandu, with depths varying from two to seven fathoms. South of Hirilandn corals seem to flourish abun- 
dantly on the outer rim of the reef flat; great patches of corals extend over it towards the lagoon side of the flat.

The southwest point of Kandudu is formed by a steep shingle beach flanked by small boulders, pitted and honeycombed. At Kandudu we found the corals on the lagoon slope of the reef flat very flourishing; they consisted of the same genera we observed before. The lagoon slope of the reef flat where we anchored is steep. The patches and clusters of corals extend from one or two fathoms to twelve, where the sand lanes begin to separate the clusters of corals; patches of corals also extend over the reef flats towards the steep beach in from one to two fathoms. The greater part of the reef flat is covered with Nullipores growing over small masses or fragments of dead or dying corals.

The northern part of the western reef flat presents no feature of importance. It is an unbroken flat, eovered at low tide, extending from Weligandu to the pass west of Kandufuri. The chart gives an excellent idea of the character of that face of the atoll.

\section{Haddummati.}

Plates 1,$6 ; 8 c$, figs. 20,$22 ; 67-70,77$, fig. 1 .

Haddummati ( $\mathrm{Pl}, 6$ ) is somewhat pear-shaped, with a huge spit forming its northeastern horn. The northwestern and southwestern fices are flanked by narrow reef flats, becoming wide near the southern side. On the northwest side are two narrow passes and a wider one on the west side. The sonthwestern reef flat is studded with islands, two of which, on the enstern extremity of the reef flat, are large. Three large islands, well inside of the wide southern pass, block its western face. The east face of Haddummati is flanked by a wide reef flat covered with many large islands; this flat narrows as we go north, the islands become smaller, and two narrow passes separate the flats of the eastern face from the great trimgular flat forming the northeastern horn of Haddummati. ${ }^{1}$ The sonthern part of the east face

\footnotetext{
1 Mr. Gardiner* has indicated slight changes from the charts in Gadu Channel, on the reef flat north of Waduni Pass and at Dambich, south of Isdu. He has left the north shore of Isdu still too far from the outer edge of the reef flat.

* Loc. cit., p. 408.
} 
reef flat is in the trend of the prevailing monsoons. Kolumadulu and Haddummati, though somewhat protected by the banks to the north, are like the northernmost atolls of the Maldives exposed both on the east and west faces to the full action of the monsoons, while Suvadiva and Addu are completely isolated from the banks to the north of them.

The greatest depth of the northern part of Haddummati is forty-three fathoms. The majority of the soundings in the central area are over thirty fathoms.

In the southern part of Haddummati are found a few sand-bars; on the whole, it is quite as clear of islands as most of the Pacific atolls. In the lagoon of Haddummati we do not meet the many faros characteristic of the northern Maldives. Haddummati belongs more to the type of a large Pacific atoll than to a Maldivian group. The greatest length of Haddummati from north to south is twenty-six miles, its greatest breadth is fifteen miles.

On the western face the majority of the islands are on the sonthem reef flat between Mavaru and Hitadu. The west face of Haddummati, sonth of the northwest entrance, is flanked by two large reef flats, with five islets on the southern one covered with low vegetation. No welldefined lagoons are found on either of the flats. The outer rims are edged with numberless patches of corals extending well over the reef flat. The horn nortl of Munafuri pass is edgerl with a narrow belt of boulders. The western faces of the islands are edged with small boulders or coarse shingle passing into coral sand towards their eastem faces. Where there are no islands, the enge of the reef flat is bordered by a belt of small boulders. At low water the reef flats are awash.

Somewhat soutl of Mavaru (Pl. 67) a nmmber of small islands run diagonally across the reef flat forming bays. The extremities on the sea face are connected by a belt of boulders and shingle forming a low ridge between them; it also gradually passes into coral sand towards the eastern end of the islands. This belt of boulders is exposed to the full force of the southwest monsoons. Further south the bays thus formed (Pl. 67, fig. 2) are closed on the eastern side by sand banks and islets or islands, covered with low vegetation, thrown up on the eastern rim of the land rim flat. 
On the west face of Phares Island rises a low shingle beach with spits extending towards the line of boulders on the outer edge of the rim flat. On the reef tlat south of Phares many spurs of coral shingle and small boulders rum at right angles from the outer edge of the rim flat to its inner edge.

The vegetation of the islands of Haddummati is fairly luxuriant, but does not compare to that of the istands on the southern groups, Suvadiva or Addu. Pandanus are quite common; there are but few hard-wood trees.

Two large islands, Kunahandu and Hitadu, separated by a long narrow gap, occupy the eastern horn of the southern reef flat. Hitadu is flanked by a shingle beach with a belt of small boulders along the outer face of its reef flat. Some large trees are seen on the eastern extremity of Hitadu.

The eastern face of the south pass of Haddummati is flanked by a wide reef flat forming the westem horn of its enstern land rim. It is edged by a narrow belt of small boulders and shingle composed in great part of small masses of coral boulders. The southern pass between Gadu and Hitadu is nearly three miles wide; facing its westeru side are three well-wooded islands. In the pass itself we could see coral heads and masses of corals separated by sand lanes in abont eleven fathoms. The color and number of the coral patehes indicates that comparatively few corals grow on the lagoon face of Haddummati. As we steamed by, off the westem face we could see, on the reef flats, a few shallow sinks, but nothing to indicate the well-defined deep lagoons on the reef flats of the northern groups.

On the reef flat opposite our anchorage off Funadu there is from three to four feet of water at high tide. 'The slope of the lagoon face of the rim flat is quite steep; in from ten to eight fathoms begin patches of somewhat delicate Madrepores followed by stouter species with Millepores and Pocillopores; in about four fathoms follow masses of Astreans and of Porites. These form great patches on the lagoon slope and in shallower water cover extensive disconnected areas, gradually diminishing as they extend over the shallower parts of the reef flat. They appear again on the bottom of the deeper parts of the reef flats; but, as a whole, the corals in the lagoon have not the flourishing appearance of those growing in the interior of the northern groups of the Maldives. 
On the southern part of the eastern land rim of Haddummati are two long islands, Fmadu and Gang; the last, nearly four miles long, is one of the longest islands of the Maldives. Between Gadu and Funadu the outer edge of the reef flat is edged by a narrow belt of small coral boulders; at the western point of Fumadu we came upon an extensive and mueh wider boulder belt than is generally found in similar positions in the Maldives. From the imner edge of the boulder belt long lines of small boulders and of shingle run to the westward. At many points the boulders have become cemented, and are deeply undercut, pitted, and honeycombed, forming occasionally a low wall on the sea faee of the reef flats. During the northeast monsoon a slight surf breaks mpon it and dies out very gradually beyond the boulder zone. There is a marked contrast between the very moderate forces at work on the outer faces of the Maldives, and the action of the gigantic Pacific rollers which pound incessantly upon the narrow and steep reef flats of the Pacific atolls. On the western faces of the Maldives the sea is much higher during the season of the southwest monsoons than it is on the eastern faces during the northeast monsoons, yet it never attains as great a height, and the surf never has the carrying power of the seas rolling north from the Southern Ocean and often transporting colossal masses of rocks high up on the beaches, or forming extensive boulder flats or high dams along miles of the sea face of some of the tropical Pacific atolls.

In the Maldives the boulder belt is generally narrow, the dams formed by it are low, and the boulders themselves diminutive compared to the size of the boulders in the Pacific. It is interesting to compare views of the boulder belts of the Pacific and Indian oceans: such regions as the great boulder flats of Aki, of Rangiroa, and of Makemo in the Pammotus, the dam at Taritari, ${ }^{1}$ with the boulder belt at Kureli Island, in the southern part of Mulaku (Pl. 65, fig. 2), the finest example we have seen in the Maldives.

On the sen face of Funadu the beaches are steep and flanked at the base with stretches of beach roek. Between Funadu and Kadu, the second island south of Gang, a large bay has been formed, closed on the sea face by a low dam of small boulders and heaps of coral shingle; behind these, sand

\footnotetext{
1 Mem. Mus. Comp. Zool., Vol. XXViII. Rangiroa, Pls. 11, 12, fig. 2; Tikei, Pl. 40, fig. 2; Makemo, Pl. 63, fig. 2 ; Funafuti, Pl. 136, fig. 2 ; Taritari, Pl. 158, fig. 2.
} 
and shingle have accumulated, forming bars and islands rumning at right angles to the line of the outer edge of the reef flat, and reaching out towards similar sand islands and bars thrown up on its imner face, thus forming a great rectangular bay enclosing an incipient lagoon, a shallow disconnected part of the reef flat, which will eventnally connect Gang with the islands to the north of it. This clearly shows the last stages in the progress of growth of sand spits from adjoining islands, gradually closing up the opening between them, until the gap is reduced to a minimum and the two sides finally become united into one island. To the north of this bay an extensive outlier of recent reef rock, somewhat higher than the surrounding reef flat, extends parallel to its outer line. This part of the edge of the outer reef flat is in many places of a reddish tint due to the growth of Nullipores upon the dead coral boulders; this is unusual in the Maldives.

The beaches of the southern part of the east face of Gang are edged with beacl rock; the reef flat is narrow in plices, the outer slope seems to be the extension of the beach rock belt; in others the eastern reef flat widens ont irregularly, the eastern face of the island is as a whole steep to. Where the reef flat is narrow or forms the shore of Gang, some of the coarse coral shingle beaches on which the surf breaks thus form the outer steep to edge of the reef flat. On one of the narrow reef flats of Gang we observed a large boulder, undercut, pitted, and honeycombed, perhaps the largest we have seen; it measured from three to four feet in dianeter. Another but somewhat smaller boulder was observed to the north of Gang, with a number of still smaller boulders scattered along the edge of the narrow reef flat. To the north of the central part of Gang the reef flat widens out again greatly, and is covered with a wide belt of small coral boulders and of coral shingle. On the northern part of Gang the beaches are mainly stretches of small coral shingle. The island south of Gang is separated from it by a narrow gap or mere ditch with a sand-bar nearly reaching across; this is perhaps the narrowest and best-defined gap we have seen in the Maldives. The small islands further to the north run generally at an angle to the trend of the reef flats, and form the sides of a series of more or less distinct bays closed on the outer edge of the reef flats by a belt of coral boulders or heaps of shingle. On the lagoon side these bays are 
partially closed by sand-bars and islets, thrown up from the west across the gaps scparating the islands forming the sides of the bays. The eastern points of these islands often extend into the boulder belt; they are generally flanked with boulders; these pass into shingle beaches and sand beaches towards the lagoon face of the reef flats. The onter spit of an island to the north of Karaidu is covered by such a mass of boulders; many of them are undercut, pitted, and honeycombed. To the north of Mandu a narrow pass with eight fathoms of water leads into Haddummati.

The northeastem hom of Haddummati is a great triangular reef flat more than five miles in length and four across its base. The extremity of the horn is occupied by lsdu (Pl. 70), a large island nearly three miles in lengtl and steep to on the northem face. The chart shows a wide reef flat smrounding Isdu, but from the position of the island it has evidently encroached on the flat, especially at the eastern extremity, so that its beaches have become the onter edge of the reef that. The great triangular hom of Haddummati is full of sand-bars, and a number of small lagoons are enclosed within the flat with from four to six fathoms of water. From Isdu to Waduni Pass, a distance of nearly fifteen miles, only one small island ocenpied the edge of the llat of the north side. A wide boulder belt extends along the sea face of the eastern edge of the reef flat. North of Mabadu Pass are ten small islands sonth of Dambidu, generally placed at an angle with the trend of the sea face; their beaches are usnally composed of coarse coral shingle, passing into finer shingle and sand towards the west. The gaps between these islands are narrow, almost choked with lines or jetties of conse shingle or small coral boulders, leaving but the merest narrow and shallow channels between many of them. Horses of eroded coral reef rock, undercut, pitted, and greatly weathered, extend from the boulder belt to the roots of the trees on the top of the beaches, showing trices of a slight former elevation of the reef flat.

Looking north across the great triangular eastern reef flat, through one of the graps (Pl. 69, fig. 2), one can see its northern edge dimly indicated by an occasional sand-bar; seen throngh the gap between Dambidu and Isdu its edge is marked by the small well-wooded islet which rises immediately to the west of Isdu. The northerm edge is also indicated by a thin 
line of breakers. The great white flat is streaked with belts of light green, light or darker blue, according to the depth of the bodies of water scattered over its surface. The line of the lagoons trends in a northeasterly direction immediately to the westward of Dambidu and of Isdu. The boulder belt is of great width on the east face of Isdu; within this belt, towards the eastem horn, has been left a small islet, an outlier of coral reef rock slightly higher than the level of the surrounding reef flats.

On the reef flats we observed a few pits and pot-holes, but not in great numbers, as on the reef flats of many of the Pacific atolls which have been planed down by the action of the surf.

Towards the east the reef flat of Isdu becomes narrower, the boulder belt and the stretches of shingle beach unite until near the eastern point the reef flat has disappeared, the slopes of the continuation of the shingle beach run rapidly seaward, the narrow wedge-shaped point of Isdu, forming the northeast horn of Haddummati, becomes steep to, and the sea breaks directly upon the coarse shingle beaches of the enstern extremity of Isdu.

A short distance to the westward of the northeast horn of Isdu, a narrow reef flat runs for a distance along its northern face, the flat gradually widens westward, and for a distance of four miles it increases in width, when it gradually narrows and passes into the long and narrow strip of reef flat which extends in a soutluwesterly direction as far as Waduni Pass. From the northern side of the horn we could trace the positions of the numerous sand-bars and banks scattered over the surface of the horn to the westward and northward of the line of lagoons.

From the rapid examination we made of the northeastern horn of Haddummati, it is difficult to determine acenrately the mode of formation of the lagoons. I am inclined to consider them as parts of the original lagoon or reef flat which have little by little been enclosed and isolated by the growth of sand-bars and patches of corals or of spits, somewhat as we find outgrowths on the edge of the reef flat to the east of Wadmi Pass and of Mavaru Island, where a part of the lagoon, with eight fathoms of water, is nearly enclosed by a coral belt. The east face of Haddummati is characterized by the great extent of land formed by the nearly continuous islands on this reef flat. Looking back from the eastern extremity of Isdu 
(Pl. 70, fig. 1), the line of islands on the east face seems like a solid stretch of land as far as Gang, and again from Gang to Gadu, with the exception of the wide gap between it and Funadu.

Mr. Gardiner ${ }^{1}$ describes Kolunadulu as ending the series of Maldive Banks in a typical atoll, yet it has a large faro with four fathoms in the velu to the northeast of Hirilandu Pass, and pools (velus according to Gardiner) with six and seven fathoms of water in the reef flats circumscribing the southem and western faces of Kolumadulu. He speaks of Haddummati as "still more perfect in shape . . . with no trace of velu." This is not the case, as in the flats of the northeast horn of Haddummati to the sonthwest of Isdu are several velus with from three to six fathoms of water. Mr. Gardiner attempts to show that the varying depths of the banks from Tiladummati to Kolumadulu is due to the perfection of the atoll condition rather than to the position of the banks on the greater Maldivian plateau. The difference in the depths of the banks is not great enough to warrant such an inference. On the contrary, the soundings indicating the pitch of the greater bank to the north and to the south point to differences in depths far greater than those of the basins of the smaller banks.

\section{Suvadiva.}

Plates 1, 6; 8r, figs. 22, 23; 71-75; 79, fig. 1.

Suvadiva (Pl. 6), one of the largest of known atolls, is somewhat pearshaped; it is forty-four miles long north and south, and thirty-four miles in breadth. Though many of the reef flats of Suvadiva have the characteristics of the reef flats of Pacific atolls, yet large stretches of the outer face of the group are flanked by faros with deep lagoons similar to those of the northern groups. Such are the great faros on the northern face of Suvadiva, along which we skirted; the faro, with its great lagoon, which forms the western face of the northwest pass into Suvadiva, and the lagoon reefs of the northwest face. A number of most irregularly shaped banks and faros lie to the south of the outer northern line of faros, and occupy a great part of the northwestern face of Suvidiva.

1 Loc. cit., p. 156. 
Along the southern part of the western rim of Suradiva we find three narrow reef flats, separated by deep passes, flanked on the western faee by numerous islands, while on the eastern faces are a number of small lagoons or bays or extensive narrows with from three to ten fathoms in depth, formed by the growth of coral patches or stretches off the eastern face of the western reef flats. These patches, becoming connected, enclose a part of the littoral area of the lagoon, shutting it off more or less from the greater lagoon. ${ }^{1}$

Notwithstanding the general resemblance of Suvadiva to some of the large atolls of the Marshall Islands, where corals do not flourish in the interior of the lagoons, yet the corals on the slopes of the interior banks and on the inner slopes of the outer reef flats of Suvadiva are more flourishing than either in Kolumadulu or Haddummati. From the great area of the deep passes opening into Suvadiva, as compared to that of Kolumadulu and of Haddummati, we can readily see how the inner waters of the group retain a far more oceanic character than the enclosed areas of Haddummati and of Kolumadulu. A glance at the cliart (Pls. 5, 6) will bring out the marked contrast existing in that respeet between these groups.

Within the lagoon many islands and a great number of small banks are scattered over the platean of Suvadiva. It should be remembered in comparing the Maldive atolls and those of the Pacific that the character of the islands in the lagoons is very different from that of the islands within the groups of the Maldives. In the former they are few in number and generally the remmants of the extensive denudation of somewhat more extended land areas, consisting of older limestone rocks, while in the Maldives the islands are the result of the active growth of corals now going on.

On the sea face of Mafuri ( $\mathrm{Pl}$. 73) horses of conglomerate run across the base of the beach and the reef flat; the position of these horses indicates

1 When diseussing the origin of the Maldives, Darwin * states that small reefs within large lagoons or hroad lagoon channels would grow up during subsidenee, and therefore would sometimes be found rising abruptly from a greater depth than that at which the effieient polypifers can llourish. 'Tlis Darwin considers to be well exemplified in the small abruptly sided reef with which the deep lagoons of the southern Maldive atolls are studded. He considers that the rings in the margin of the northern Maldive atolls, althongh broader than the exterior of an ordinary atoll are only modified portions of sueh a reef, and that the central rings oceupy the same relative position as the knolls occurring in lagroons.

$$
\text { * Lor. rit., p. } 141 .
$$


a former slightly higher elevation of the reef flats. On the sea face the beach has been thrown up from four to five feet above the highest point of the beach conglomerate, thus flanking what appears like a shallow sink, - a low, somewhat swampy depression.

As we passed Huradu, we could not fail to notice its luxuriant vegetation, as well as the splendid growth of trees found on the islands (Pl. 74, fig. 2) to the south of Mafuri (P1. 72), and on our way to Dandu across Suvadiva, as well as on the eastern and southern faces of Suvadiva. Iatedu, one of the central islands, is also covered with luxuriant vegetation, its narrow reef flat is edged with great patches of corals, the beach is flanked with beach rock and small horses of conglomerate, as on the sea face of Mafuri.

The great lagoon of Suvadiva is fairly clear of patches; though, as I have already stated, a great number of banks and bars are seattered throughout the group, principally near the land rim, on all of which the masses of colored patches of corals extending from the edge of the flats indicate a most luxuriant growth of reef corals. Many of the low sand-bars were covered with numberless black terns, with white heads, great flights of which were met with in all parts of the lagoon.

During January the elimate of Suvadiva and of the southern Maldives differed greatly from that of the northern part of the arehipelago. The southern Maldives are in the region of variable winds, and rain and squalls from the northwest are frequent.

A great, slightly submerged reef flat, nearly a mile wide encloses Daudu and Hura Mula, an island to the south. At the base of the inner beach of Dandu extend (Pl. 75) stretehes of slabs of beach rock, and high, steep sand beaches fringe the island. The prineipal trees consisted of Pandanus, Bread-fruit, Hibiscus, and a few other hard-wood trees.

Sonth of Dandu the east face of Suvadiva is flanked by a number of wide reef flats well marked by the onter line of breakers, with islands of considerable size, ${ }^{1}$ as Maldive islands go, all of which are well wooded. 'To the east of the islands the reef flats are unusually wide. In the lagoon

\footnotetext{
1 They are such islands as Hura Mula, Mamadu, Wegeli, Funadu, and many others on the east face as far south as Gau.
} 
itself, Hanlus Island is covered with large trees. In Dandu Pass we found the corals, judging from the extent of the patches, to be growing in great abundance on both sides of the pass, on the reef flats flanking it to the north and south.

On the eastern points of many of the islands on the east face masses of small coral boulders were thrown up on the outer edge of the reef flats. Shingle beaches also stretched along the more exposed faces of the islands; the base of the steep shingle or sand beaches was frequently protected by stretches of beach rock. Diaddu Island is marked by a long spit extending westward nearly two miles beyond the entrance of the pass to the north of the island.

On the east face of the island to the north of Kandu Huludu (Pl. 74, fig. 1) are several fine stretches of shingle beaches. At the south end of Kandu Huludu a large, elongated bay has been formed by the shutting off of a part of the reef by coral boulder and reef rack ledges and slingle beaches thrown up along the outer edge of the reef flat. Other reef rock ledges also crop out on the reef flat between the sandy beaches of the bay and the outer line of breakers on the edge of the reef flat. Long bays, like the one described above, when closed by the junction of points of adjacent islands, form a shallow lagoon parallel in a general way to the trend of the outer reef flat; while, when formed by patches parallel to the immer edge of the reef flat, which have enclosed parts of the lagoon, they often become lagoons of considerable depth. It should be remembered that in the building up of a faro, the walls are continuous and usually enclose a deep lagoon, while the lagoons on reef flats are generally shallower, and their rims formed by the coalescence of independent coral patches or bars of sand or of recent reef rock; this often crops out on the reef flat between the inner edge of the reef flat and the outer line of breakers.

The western point of the wide reef flat to the south of Kandu Huludu is edged by a well-marked belt of coral boulders and of reef rock ledges with heaps of coarse coral shingle, forming incipient islands on the western face of the reef flat. The east face of Huluwarolu, to the south of Kandu Huludu Pass, is flanked by high shingle beaches. 
Althongh several of the passes into Suvadiva are shallow, ${ }^{1}$ south of Madu we have only sis fathoms in the channel, south of Diaddu and of Kandu Huludu, seven, yet the greater number are wide and deep, admitting free access to the ontside sea, so as to make Suvadivi a strictly oceanic atoll, if I may so call open atolls of great depth like Suvadiva. Suvadiva has a greatest depth of forty-nine fathoms, with the majority of the somdings near forty fathoms. It is by far the largest body of deep water in the Maldives; and though it contains at least two hundred islands and banks, they are quite lost in this huge atoll, and so far apart that one often seems to be steaming at sea or through an archipelago of small distant islands, or making for the outer rim of a neiglhboring atoll, as when passing from the face of one group to another. The dark color of the deep enclosed waters adds to the deception.

Many bays are to be seen on the sea face of the larger islands on the eastern side of Suvadiva, plainly showing that the larger islands have been formed by the coalescence of smaller ones, joined at first, perhaps, merely by a shingle bar, or a line of coral boulders or of sand-bars. With the accumulation of material the connecting belt of shingle becomes a string of banks or of islets, till finally the outer extremities of adjoining islands are united, and a shallow sheet of water is enclosed within three sides of a rectangle. The open lagoon face in its turn is barred in the same way by chains of sand-bars or islets; they, in their turn, become united, and thus a closed, shallow lagroon is formed. The long island of Huluwarolu is only in a more advanced state of coalescence than the smaller and still independent islands and islets to the south of it. On the west face of Suvadiva a similar process has been going on, but the islands are nore disconnecter than on the east face. Only a few larger islands have been formed on the reef flats of the western face, such as Havaru, Kindudu, Hondedu, and Nadale. The western reef flats are edged with numerous small islands and islets, until we reach the large islands on the sonthern reef flats of Suvadiva, like Fiori and Matoda, all composite islands, like those of the east face.

1 In a number of the passes of the central Mlaldives, the onter soundings on the rim are shallower than those on the inner faces; they indicate the submarine extension of the crest of the adjoining reef flats, and arc well within the depths at which corals may grow.

The same is the case in a few of the passes of the northern Maldives, the northern passes of Haddummati, and many of the passes on the faces of Suvadiva and of Addu. 
The sea face of the islands on the east face of Snvadiva are flanked by coarse shingle beaches; they pass, as is usually the case, into finer shingle towards the west, and on the lagoon face the beaches become coral sand beaches. Numerous shingle jetties, passing into sand-bars, run at right angles from the outer edge of the reef flats. They are the first indications of small islets which eventually become covered with scanty regetation, and become comnected at the sea or lagoon faces to form the larger islands reaching nearly across the width of the reef flats.

The original gaps between the islands or islets vary greatly in width. Sometimes they are not more than a few yards wide, or they may be nearly a mile across, their width depending in a great measure upon the exposure of the faces of the reef flats to the prevailing winds, the abmiance of corals on their sea slopes to supply the material for the bonlder belts, reef rock ledges, and shingle or sand beaches which are to fill the graps. A shingle bar often rises in the centre of a bay, rumning parallel to the outer edge, thus forming a shallow lagoon divided into two distinct pools.

South of Dandu (Pl. 75) the sea face of the reef flats are generally lined with boulder's and large masses of corals, honeycombed and pitted, remnants of the elevated reef rock, or with smaller masses of corals and coral shingle, forming lanes and jetties extending towards the lagoon. The eastern extremity of the islands, which extend close to the eastern edge of the reef flats, are flanked with masses of boulders or with coarse coral shingle beaches, gradually passing into coral sand beaches towards the west. The passes between the reef flats, as at Gadu and Gan, are usually flanked by wide reef flats edged with a belt of boulders or of shingle; the onter shores of the islands are



BOAT OFF GADU. flanked by shingle beaches. A few bars of reef rock crop up on the outer reef flats inside of the boulder belt, with an occasional stretch of beach rock at the base of the shingle or coral sand beaches.

Gan Channel and the passes between it and Wadu, although partly 
closed by reef flats and faros, yet form a series of wide, deep openings for a distance of more than eight miles; they allow a great mass of water to How in and out of the southern face of Suvadiva. Four of these passes are more than thirty fathoms deep. A single such pass would almost give to the enclosed waters an oceanic character; and if we add to this the mass of water entering through the many passes of the western, southern, and eastern faces, one can form some idea of the volume of water constantly pouring in and out of Suvadiva, in addition to what is forced into it over the reef flats.

On measuring roughly the width of the passes and length of the reef flats of Suvadiva, and taking from these the length occupied by the islands on the reef flats, it will be found that the open spaces are large in comparison to the bars formed by the islands. There are at least twenty-six miles of deep passages leading into Suvadiva. The remainder of the periphery is occupied by reef flats, over which water passes freely at all stages of the tide. Taking the periphery of Suvadiva to be about one hundred and thirty miles, not more than forty-five miles of it is occupied by islands and islets. Thus on fully two thirds of the circunference of Suvadiva oceanic waters pass freely into the lagoon. This readily accounts for the great purity of the inner waters, the rim being a very open sieve.

The corals growing on the slopes of the bars and banks and islands of this huge enclosed basin are bathed by currents bringing an abundant supply of oceanic water, though they are not washed by as strong a surf as are the outer faces of the land rim of Suvadiva, especially churing the period of the sonthwest monsoon. The greater strength of that monsoon is elearly indicated by the trend of the summit of the trees and bushes on the sea face of the western side of Suvadiva, on the islands in the atoll, and on the lagoon face of the islands of the east side. Steaming north from Gan Channel through the eastern part of Suvadiva in the clirection of Dandu, we passed a number of small banks and islands all accurately plotted on the chart; they presented no points of special interest. The islands were evidently formed upon banks or faros in the manner already described, some of them occupying but a limited area of the bank, others a somewhat larger one, and others the whole of the bank, being steep to and leaving only a 
small or a narrow rim as a reef flat. The southern islands in the basin of Suvadiva, like those to the west of Gan and in the northern part of the atoll, are covered with luxuriant vegetation. The trees form great clumps, reaching close to the top of the steep sand beaches; as a rule, but few cocoanuts grow on the islands. Hanlus and Labadu are excellent examples of Suvadiva lagoon vegetation.

Corals were growing in great profusion on the edge and part of the flats of the banks we passed, forming spits in the direction of the stronger of the prevailing winds. On the southern face of Suvadiva a number of crescent-shaped banks have been forned with crescentic islands; they resemble the more irregular faros of the northern groups. Where strong currents exist, as through the channel between Gan and Wadu, the corals have grown in spits and form the erescent-shaped banks of the southern face of Suvadiva.

Matoda is one of the larger crescent-shaped islands on the westeru extremity of one of the southern reef flats. They have probably been formed by the coalescence of adjacent patches growing parallel to the lagoon face of the reef flat. On the western face the coral patehes have formed small bays, eventually uniting the eastern extremities of the islands and islets on the outer edges of the reef flats.

At a depth of nine fathoms in the pass to the north of Wegeli, we could plainly see the bottom covered with patches of masses of corals. 'To the north, the islands of the east face are well elothed with luxuriant vegetation, some of the trees being of considerable size. The litgoon faces of the reef flats we examined slope rery gradually. 'The boulder belt is specially developed on the east face of the reef that of Funarlu, and to the south of the northern spit of the island. At Digura the boulder belt forms an incipient dam on the outer edge of the reef flat; within that patehes of recent elevated reef rock, pitted and honeycomberl, stam ont at a somewhat higher level than the surromding reef flat. Stretches of beach rock extend along the base of the sea beaches of many of the islands on the east face of Suvadiva to the north of Funadu.

\footnotetext{
1 Mr. Gardiner eonsiders these pratehes to be remnants of the breaking up of a long line of reef.
} Loc, cit., P. 413 . 
The outer rims of the reef flats of the Maldives are in striking contrast with those of the Pacific atolls. The latter are characterized by the presence of the deep tongues of water penetrating well into the reef flats, scalloping the cxterior edge so that the whole becomes a mass of broad digitate lobes, many of them forming diminutive boat harbors. These lobes are separated by high, rounded masses of brilliantly colored Millepores, Pocillopores, and Nullipores. Nothing of this kind exists in the Maldives; the edge of the reef flats is sometimes flanked by a low wall of coral, or a belt of boulders, or by colored patches of corals extending over the outer part of the reef flat, forming a very insignificant border as compared to its Pacific representative.

The sonthem point of Kudu is flanked by a steep coarse shingle beach, with a few coral boulders on the outer edge of the reef flat, forming the north face of the pass to the south of the island. The shingle beach passes into fine shingle and sand towards the west. To the north the edge of the outer reef flat is flanked by a wide belt of coral boulder, forming occasional heaps backed by shingle and sand, with short stretches of coral reef rock, pitted and honeycombed, rising slightly above the general level of the surrounding reef flats.

There are three bays on the east faces of Wiringili, formed by outer lines of coral boulders and heaps of coarse shingle, connecting projecting points of the island; they indicate plainly where the gaps existed which once cut Wiringili into a number of separate islands that are now united. Their former separation can also be detected by the low vegetation growing on the sand-bars connecting the separate islands, contrasted to the large trees that grow on the older parts which once existed as separate islands, as they are still marked on the charts; changes like these are the most prominent errors that can be detected on the charts. To the north of Wiringili are extensive patches of recent reef rock, slightly elevated, undercut, and pitted, and honeycombed; the outer edge of the flat is flanked with a belt or heaps of coral boulders.

The great reef flat which forms the northeastern horn of Suvadiva extends unbroken in a northwesterly direction from Wiringili for more than ten miles; with the exception of the islets north of Wiringili, there are no 
islands on it until we reach Mameta, about halfway to the northern extremity of the reef flat. The water on the reef flat is shallow; many sandbars rise from it. North of Wiringili a narrow velu extends almost to Mameta, it is indicated on Mr. Gardiner's chart of Suvadiva ${ }^{1}$ the outer edge is flanked for nearly its whole length by a boulder belt, or by heaps of shingle and small boulders.

It will be seen that I differ greatly from Mr. Gardiner ${ }^{2}$ in considering Suvadiva as an open and oceanic atoll, and do not-as he does-look upon its rim as anything but perfect. Mr. Gardiner circumnavigated the lagoon of Suvadiva, and paid special attention to the lagoon face of the western encircling reef. He considers the differences he noticed in the existence of reef patches on the enstern face of Hondedu and east of Fiori as due to the breaking up of the reef, which is inclicated as continnous on Moresby's Chart, and to the fusion of the separate velus into one. The islands of the west face south of Nadale are evidently washing away on the lagoon face. ${ }^{3}$

Mr. Gardiner has in his chart of Suvadiva ${ }^{4}$ indicated the depth of the central flat as ranging from forty to fifty fathous; the majority of the soundings on the Admiralty Chart in that region are less than forty-five fathoms, with only one sounding of forty-nine fathoms. Mr. Gardiner infers from his line of soundings between Gadu and Nadale that there has been an increase in depth of about two fathoms in that part of the lagoon of Suvadiva. He further concludes that as the coral shoals and heads in the interior of the lagoon are precipitous to thirty fathoms, they could not have arisen from a base of that depth, and that the greater depth must be due to solution of the bottom of the lagoon; while recognizing the efficiency of solution that does not preclude reef corals from obtaining a foothold at that depth.

On comparing his line of soundings with those on the Admiralty Chart, the two deepest soundings, 48 and 46 , are in an area not sounded by Moresby, and there is nothing to indicate that they may not have been the normal soundings in 1835 as much as the soundings to the eastward.

\footnotetext{
1 Loc. cit., Pl. XXI.

2 Loc. cit., p. 409.
}

8 Loc. cit., p. 413.

4 Loc. cit, PI. XXI. 
As to the missing shoal marked in passage to the south of Kuradu, that may have been wrongly marked, or merely a spur of the reef flat projecting into the passage, much as we found coral patches growing in great abundance on both sides of the pass north of Dandu.

Mr. Gardiner states ${ }^{1}$ that on the west face of Suvadiva the islands south of Nadale are wasting on the lagoon face, while north of Nadale to Hondedu "they show little or no sign of erosion." So are many of the islands of the east face, yet a number are sending out very marked spits lagoonward from the angles of their lagoon faces, as are the islands on the south face between Gan and Wadu. Some of the islands we passed in the lagoon seem to be wasting on the western faces.

On the west face, according to Gardiner, great changes have taken place in the shape of the land of Tinadu; he considers the two passes to the south to be closing (he could not examine them), and yet in the immediate vicinity the lagoon was deepening, as he anchored in twenty fathoms where the chart marked seventeen. Owing to the changes of the shape of the reef flat the evidenee is not very conclusive, specially as less than a quarter of a mile off, soundings are given of twenty-five and twentythree fathoms; he considers the hook-shaped spit to the east of Tinadu as indicating the former presence of a velu now opening into the lagoon.

1 Loc. cit., 1. 413.



UNder the Wing of the ('Hef l)ande. 


\section{Fua Mulaku.}

Plates 1, 6, sc, fig. 23.

We were unable to visit the island of Fua Mulaku; it rises in the Equatorial Channel from a deptl of about thirteen hundred fathoms, at a distance of less than two miles. It is twenty miles distant from Addu, and trends in a northeasterly direction. The island is two miles long, about three quarters of a mile wide, steep to, except at the southeast face, where a long shoal with soundings varying from two to seven fathouns extends for about one and a half miles southward. Mr. Gardiner ${ }^{1}$ states that, according to native accounts, Fua Mulaku has a pool of fresh water in the centre.

\section{Addu.}

Plutes 1,$6 ; 8 c$, figs. 21, 23; 76, 77, fig. 2 .

While some of the larger groups of the Maldives, like Kolumadulu, Haddummati, Suvadiva, and Felidu, bear a close resemblance to atolls in the Paumotus, the Marshall, Ellice, and Gilbert Islands, yet the groups which most resemble the Pacific atolls are smaller atolls like Addu, Wataru Reef, Rasdu, Gaha Faro, Goifurfehendu, Fadiffolu, Makunudu, and Ihavandiffulu.

Addu (Pl. 6), perhaps, is more like some of the Pacific atolls than any other Maldivian group. It is isolated from the rest of the groups, fifty miles from the nearest atoll to the north, and its position reminds us of that of Fumafuti, one of the atolls of the Ellice group, forty miles distant from Nukufetan, the next island to the north, separated by a clannel more than twenty-four hundred fathoms deep. Between Addu and Suvadiva we have a depth of over twelve hundred fathoms.

Addu on the south is as far isolated from the Maldives as is Minikoi on the north, both resembling low Pacific atolls, and quite different in structure from the typical Maldivian atoll; both are bounded by reef flats, not by faros; but the climatic conditions under which they are placed are quite different. Minikoi is in the region of the northeast and southwest monsoons, while Add $u$ is in the equatorial region of variable southerly and westerly winds,

1 Loc. cit., p. 419. 
with rain squalls prevailing. These conditions readily explain the differences existing in the development of the land rims of Addu and of Minikoi.

Addu (Pl. 6) is irregularly triangular in outline, and seven miles from north to south; its northern face is concave, about ten miles long, while the others are slightly convex. The hook-shaped extension of the northern point of Hitadu Island forms the northwestern horn of Addu, and the islets extending westward from Midu flank the northeastern horn of the atoll. There are two narrow and comparatively shallow passes, separated by islets on a reef patch, in the central part of the northern face, and two wider passes, the southeastern and the southwestern (Pl. 77, fig. 2). Wide and continuons reef flats occupy the whole of the western and eastern faces; the flats are narrow along the northern face of the atoll.

At Midu on the northeast corner of Addu the vegetation of the eastern face is quite luxuriant; that of Wiringili, the island flanking the western face of the sontheast pass of Addu, being, perhaps, as luxuriant as that of any island in the Maldives. This fine vegetation extends to the islands on the west face; though south of Huludu the vegetation is poorer, and in some of the smaller and narrow islands to the north of the southeast pass it is reduced to mere scrub, so that steaming along the east face one can look into the lagoon across the narrow belt of islands and islets. The eastern edge of the reef flat is edged by a wide belt of masses of boulders reaching the very base of the shingle beaches on the outer face of the islands. Such a narrow land rim reminds one of similar lines of islands in the Marshall Islands, where they form the merest wall separating the lagoon from the ocean. On the sea face of Midu a wide sandy bay, separated from the ocean by only a narrow belt of boulders, occupies the central part of the island.

The shingle beach on the outer face of Wiringili is, perhaps, the highest we have seen in the Maldives. Slight changes have taken place since 1836 in the topography of Wiringili, as represented on the chart. The loug sand spit edging the reef flat on the west side of the pass did not exist, and the island to the west of Wiringili was not connected with it by a sand spit, as it now is, these additions forming the sides of a great bay enclosing three sides of the Wiringili reef flat. 
The southern part of the eastern face of the southeast pass is flanked by a long spit edgred by a belt of coral boulders, with patehes of shingle near the western extremity of the spit, the position of which is clearly indicated by a line of breakers skirting its edge.

The largest islands of Addu are on its western face, separated by comparatively narrow gaps. Several of the islands on the western face are throwing out spits towards the onter edge, and forming bays partly shut off from the sea. $\quad$ The larger islands all show traces of having been made up of separate islands now mited by sand spits or bars. This is well seen at Hitadu on the western and at Midu on the eastem face. The lagoon beaches of the islands of Addu are high and steep, far steeper than those we have seen near any of our anchorages.

The northern part of the southeast face is flanked by a reef flat at the angle of which is the large island of Midu, forming the northeast horn of Addu. To the south of Midu the greater part of the reef flat is occupied by a line of narrow islands far smaller than those on the west face of Addu; they do not compare in size with Hitadu, which is four miles in length and a mile wide in places.

There are no islands in the lagoon of Addu, and only five small sand-bars. The greater part of the lagoon is about thirty fathoms in depth; it varies from twenty-four to thirty-nine fathoms, its greatest depth.

At $\mathrm{Gan}$ (Pl. 76) the vegetation on the lagoon side reaches to the summit of the beach. In places the lagoon seems to be slightly encroaching on the

\footnotetext{
$1 \mathrm{Mr}$. Gardiner* has ealled attention to the seven small islands thrown up (since 1835) off the west face of Gan and Faidu, elose to the onter edge of the reef flat. Aeeording to him, the topography of the northeast horn of Addu, which we did not visit, has been eonsiderably modified. The line of small islands to the west of Midu consists of a greater number of jslands than is indieated on Moresby's Chart. $f$ The western face of the flat of the northeast horn is figured by Gardiner as much wider than on the Admiralty Chart, having eneroached upon the northeast bay of the lagoon, and formed a false velu, $\neq$ as be calls the deep and narrow strip of water, five fathons deep, separated fron the lagoon by an outer reef. Sueh false velus are like those of Tahanea, and are found in many of the Paumotus. I have ealled them secondary lagoons. \$ In the Paumotus they are usually parallel to the outer reef flat. The northwestern horn, which was charted elear of coral heads by Moresby, is now partly shut off by coral knolls. He also states that the bank off the western point of the eastern reef flat of the southeastern pass has beeome united with the reef flat; it is, however, on his ehart still indieated as an independent bank. The bank with seven fathoms on the opposite side of the pass is, I think, a spit of the western face of the pass.

$$
\begin{aligned}
& \text { * Loc. cit., p. } 415 \text {. } \\
& \dagger \text { Loc. cit., pp. } 318,415 \text {. }
\end{aligned}
$$$$
\ddagger \text { Loc. cit., p. } 415 \text {. }
$$$$
\S \text { Mem. M. C. Z., Vol. XxVIII., p. } 86 .
$$ 
land. On the lagoon slope of Gan corals, although growing in many irregular patches, yet do not seem to me to grow as vigorously as they are stated to do by Gardiner in Addu. ${ }^{1}$ In from eight to ten fathoms the matsses already grow somewhat apart, and gradually become separated by wide lanes of coral sand.

$1 \mathrm{Mr}$. Gardiner states that Addu is filling with sand deriverl from the disintegration of the eoral growth, whieh, taken as a whole, he says, "quite surpasses in viror anything in my experienee elsewhere, either in the Mlaldives or in the l'aeific." This Mr. Gardiner bases on soundings taken by Mr. Cooper,* and asks for a comparison of his amended chart with the Admiralty Clart, though Mr. Gardiner recognizes the uselessuess of isolated soundings, from the diflieulty of fixing points of reference, due to ehanges in the land; he says, "we could get no even approximatively fixed points for our sight." $\dagger$

Mr. Gardiner on his amended eluart places the northeast point of Addu nearly half a pnile more to the eastward than Moresby, and thus shows a great inerease in the dimensions of the northeast horn flats; this renders it impracticable to loeate Mr. Cooper's soundiugs on the Aduiralty map. Taking the general trend of the lines south of IIngadu - Gardiner, loc. cit., p. 415, fig. 109- to the western spit of the southeast passage, thence towards Ilika and the line immediately south of the northwestern passage with its northeastern extension to Balihura, we do not find Mr. Cooper's soundings sufficiently elose to the positions of Moresby's soundings to warrant his eonelusions. Mr. Gardiner's soundings of thirty-our fathoms, or any other, as plotted, do not come suficiently near the thirty-nine-fathom spot of MIoresby to be proof of a ehange of level of eight fathoms.

Granting that in Addu, being ontsile the influence of the trades, $\ddagger$ the eurrents due to them eannot affect the eireulation of its lagoon as greatly as in more open northern atolls, yet the cireulation due to the tides alone is sulficiently active to induee comparatively rapid change in the waters of the lagoon. Mr. Gardiner aseribes the filling of the lagoon "rather to the want of solution" and deerease in depth of the passages (which is not demonstrated) "tlum to the luxmiant growth of corals;" yet the northwestern horn has been shut off by eorals since 1836. Against this $\$$ he sets the possible deerease of the area from which the sediment is supplied, which he attributes in one case to increase of land, and in the other looks upon it as an "effective souree of sediment." While aeknowledging the important ageney" of solution in modifying the lydrography of a lagoon, it secms hazardous to measure its efficieney by the comparative surveys made by $\mathrm{Ir}_{\mathrm{r}}$. Garliner in the Malelives: $\|$ its existence and extent is far more readily perceived in the changes whieh, by analogy, we may fairly estimate in sueb atolls as Fulanga, Argo, Ongea, Yangasá, and others in Fiji. I

Mr. Gardiner estimates** that five-sevenths of the lagoon of Addu is protected by land, and that there are but ten miles of flats over which water ean have access to the lagoon. It certainly is well protected on the west face, and on a good part of the eastern faee; but it seems to me that Mr. Gardiner's estimate of the effeet of this protection is altogether tongreat. Ten miles of flats, together with two ehannels with only a narrow irregular rilge separating deep water from the lagoon, is an area quite suffieient to allow a fair eirculation of water in the lagoon, and to aeeount for a better growth of corals where the water from the flats strikes the lagoon. Mr. Gardiner speaks of the water in the lagoon of Aildn "as considerably elenrer than in most basius." $\dagger \dagger$ Our experience during our short stay in Addu wis quite the contrary; the water was everywhere remarkably turbid. Although the reef flats of Addu average more in breadth than those of any of the other NIaldive groups, yet the difference does not appear important enongh to sustain Mr. Garliner's conelusions that although there bas been solution, now there is little solution, owing to the want of cireulation, for aceording to his views, when au atoll is more or less elosed, then begins the period of solntion in deptll.
* Loc. cit., p. 318 .
$\dagger$ Loc. cit., p. 415.
$\S$ Loc. cit., p. $32 \mathrm{t}$.
*** Loc, cit., p. 320.
+ Loc. cit., p. $32 \mathrm{t}$.
\| Loc. cit., p. 323.
$\uparrow \uparrow$ Lor. cit., p. 320
T Bull. M. C. Z., Vol. XXXill1, py. 57, 60, 62. 


\section{TEMPERATURE OF THE LAGOONS.}

THE bottom temperature of the lagoons of the Maldives differs but little from that of the surface.

At Addu, the northern part of Suvadiva, Haddummati, Kolumadulu, Fadiffolu, and Tiladummati, the temperatures were identical. The bottom temperature was slightly colder (from $0^{\circ} .5$ to $1^{\circ}$ ) at North Malosmadulu, the southern part of Suvadiva, Mulaku, and Ari. While at Felidu and North Male the bottom temperature was $0^{\circ} .5$ warmer than the surface. The water was from $0^{\circ}, 5$ to $6^{\circ}$ warmer than the air at Haddummati, Suvadiva, Addu, Kolunadulu, Felidu, Fadiffolu, North and South Malosmadulu, North Male, and Tiladummati. In the sonthern part of Ari we found the temperature of the air $1^{\circ}$ greater than that of the surfice.

The water of the atolls is evidently heated to a temperatmre above that of the adjoining oceanic waters. According to the observations of the "Valdivia" between the Maldives (Suvadiva) and the Chagos Archipelago, the temperature at a depth of fifty metres was $26^{\circ}$ Centigrade, and that at seventy-five metres had dropped to $21^{\circ} .8$ Centigrade. ${ }^{1}$

The following observations were made:

Temperatures usually taken at 8 P.M.

Dec. 28, 1901 . Air, $84^{\circ}$ at anchor off Ariadu (Ari). Surface of water, 83.5 (Fahrenheit).

Bottom, $82^{\circ}$, thirty fathoms.

Dec. 29, 1901. South part of Mulaku at anchor in thirty-four fathoms.

Surface, $83^{\circ}$.

Bottom, $82^{\circ}$.

\footnotetext{
1 Temperatur Curven, Pl. XXIII., Wiss. Ergebnisse d. Deutsehen Tiefsee Expedition. Text, Eister Band, 190\%.
} 
Jan. 1, 1902. South part of Haddummati at anchor in twenty-seren fathoms.

Air, $79^{\circ}$.

Surface, $82^{\circ}$.

Bottom, $82^{\circ}$.

Jan. 2, 1902. North part of Suvadiva (Mafuri) at anchor in twelve fathoms. Air, $79^{\circ}$.

Surface, $82^{\circ}$.

Bottom, $82^{\circ}$.

Jan. 4, 1902. Sonthern part of Suvadiva (Gadu) at anchor in twentyeight fathoms.

Air, $77^{\circ} .25$.

Surface, $81^{\circ} .5$.

Bottom, $81^{\circ} .75$.

Jan. 5, 1902. Southern part of Addu (off Gan) at anchor in twenty-two fathoms.

Air, $76^{\circ}$.

Surface, $82^{\circ}$.

Bottom, $82^{\circ}$.

Jan. 9, 1902. At anchor off Kandudu (Kolumadulu) in twenty-four fathoms.

Air, $80^{\circ} .5$.

Surface, $82^{\circ}$.

Bottom, $82^{\circ}$.

Jan. 11, 1902. At anchor off Buri Hura (Felidn) in twenty-six fathoms.

Air, $82^{\circ}$.

Surface, $82^{\circ} .5$.

Bottom, $81^{\circ} .5$.

Jan. 13, 1902. At anchor off Kagi (North Male) in twenty-two fathoms.

Air, $80^{\circ}$.

Surface, $81^{\circ}$.

Bottom, $81^{\circ} .5$.

Jan. 14, 1902. At anchor off Maro (Fadiffolu) in twenty-six fathoms.

Air, $80^{\circ} .2$.

Surface, $81^{\circ} .5$.

Bottom, $81^{\circ} .5$. 
Jan. 15, 1902. At anchor off Turadu (South Malosmadulu) in twentyone fathoms.

Air, $79^{\circ}$.

Surface, $81^{\circ}$.

Bottom, lost thermometer.

Jan. 16, 1902. At anchor off Medu (North Malosmadulu) in twenty-one fathoms.

Air, $80^{\circ}$.

Surface, $81^{\circ} .5$.

Bottom, $81^{\circ}$.

Jan. 17, 1902. At anchor off Anguretin (North Malosmadulu) in twentyeight fathoms.

Air, $80^{\circ}$.

Surface, $81^{\circ} .5$.

Bottom, $81^{\circ}$.

Jan. 19, 1902. At anchor off Hanimadu (Tiladummati) in sixteen fathoms.

Air, $81^{\circ} .5$.

Surface, $82^{\circ}$.

Bottom, $82^{\circ}$. 


\section{BOTTOM DEPOSITS IN THE LAGOONS.}

AT a number of localities, generally at our anchorages in the Maldives and in the central parts of the lagoons, we collected samples of the bottom deposits as well as of the sand or other material forming the beaches, both of the lagoon and of the sea faces of the islands we visited. It is proposed to work up this material in connection with similar collections made during my explorations of the coral reefs of the Pacific and West Indies. I hope later to publish a report on the extensive collections brouglit together to illustrate the nature of the lagoon and beach deposits on coral reefs.

A few notes only are given here to show the character of the bottom of the Maldive lagoons. ${ }^{1}$

At anchor off Male Island, in twenty-six fathoms, the bottom consisted of broken and rolled coral fragments covered with Nullipores.

At anchor off Kagi, extreme northern part of North Male, in twenty-two fathoms, the bottom was covered with sponges and Nullipores, and fragments of coral.

At anchor off Maro (Fadiffolu), in twenty-six fathoms, the bottom consisted of fine gray coral sand, the dredge brought up many shells, a few Crustacea, and a Maretia.

At anchor off Turadu (South Malosmadulu), in twenty-one fathoms, the bottom was composed of Corallines and Algae, with Orbitolites, Nodosoria, with masses of broken and worn shells and fragments of Laganum and of Metalia.

At anchor off Medu (North Malosmadulu), in eighteen fathoms, the bottom consisted of Nullipores, Corallines, Alyae, and dead corals.

At anchor off Anguretin (North Malosmadulu), in twenty-eight fathoms, the bottom made up of broken shells, coral sand, and Corallines.

1 An interesting analysis of the deposits collected by Mr. Gardiner, prineipally in the huge lagoon of Suvadiva, has been given by Sir John Murray; this is supplemented by general notes on the lagoon deposits of the Maldives from Mr. Gardiner (loc. cit., p. 581). 
At anchor off Nalandu (Miladummadulu), in twenty-four fathoms, the bottom consisting of coarse coral sand and sponges.

At anchor off Hanimadu (Tiladummati), in sixteen fathoms, many specimens of Asymmetron came up in the dredge from a Coralline bottom. Mr. Gardiner ${ }^{1}$ collected his specimens mainly on sandy bottoms exposed to currents. We collected Asymmetron lucayanum (Andrews) in abundance in the sand of some of the northern groups in twenty to thirty fathoms.

At anchor off Kuludu (Miladummadulu), in twenty-three fathoms, we found a bottom of coarse coral sand and broken shells.

Off Turadu, in thirty fathoms, the bottom of Ari is composed of broken corals and shells and coral sand.

At our anchorage inside Ariadn, in thirty fathoms, we found the bottom to consist of coarse fragments of coral.

At anchor off Buri Hura, in twenty-six fathoms, the bottom consisted of fine sticky bluish coral sand.

The bottom near the southern horn of Mulaku, in thirty-four fathoms, was made up of very fine coral sand. This part of the group is not sheltered by a land rim, the sea can sweep across the rim flats; we find the bottom often consists of a fine sticky ooze, such as we find in similar conditions in Pacific atolls.

The bottom of Kolumadulu, off Timarafuri, in twenty-nine fathoms, is hard, consisting mainly of large pieces of broken corals.

At anchor off Kandudu (Kolumadulu), in twenty-four fathoms, we found a bottom of coarse coral sand with a few broken shells.

The bottom at the south end of Haldummati, off Funadu, in twentyseven fathoms, consisted of fine coral sand, somewhat sticky, and broken shells. At anchor near our former anchorage, off Funadu, at the sonth end of Haddunmati, we obtained in twenty-eight fathoms a bottom composed of Nullipores and Corallines.

The bottom off Mafuri anchorage (Suvadiva), in twelve fathoms, consisted of coarse coral sand, rather sticky, and broken shells.

The bottom at anchor off Dandu (Suvadiva), in twenty-four fathoms, was hard, covered with Corallines and Algae.

$$
1 \text { Loc. cit., p. } 359 .
$$


The bottom at anchor off Gadu, in twenty-eight fathoms, was hard, swept clean by currents.

Sounding in thirty-nine fathoms in the centre of the northern part of Suvadiva, we brought up a piece of Millepora evidently cut off from a living cluster. This is a far greater depth, I bclieve, than that at which any reef builder has as yet been dredged. In making a second sounding nearly in the same position, we found the bottom to consist of Corallines, Coralline fragments, and sand and ooze.

The bottom off Gan (Addu), in twenty-two fathoms, was somewhat sticky and consisted of coarse coral sand mixed with Corallines and broken shells; we brought up in the dredge a number of specimens of species of Balanophyllia. In all, the smooth base was perforated near one extremity by an opening leading into a cavity occupied by a small Sipunculoid. 


\section{THE PEIAGIC FAUNA OF THE MALDIVES.}

A Number of pelagic hauls were made in the atolls, and a few deep intermediate hanls off the principal passes into them.

We usually towed in the evening from the ship, while at anchor. Off Male Island we collected five or six species of Copepods, Atlanta, Styliola, Hyalea, and other Pteropods. ${ }^{1}$ Small Salpae with blue nucleus, Sagittae, Sapphirina, Hyperids, Collozoum, bells of Siphonophores, Diphyes, young Fishes, Thrichodesmium, Sergestes, Antolytus, Oceaniae, and Crustacean larvae. From another haul, with a strong current from the east coming through the southeast pass, we obtained many Sagittae, Sapphirina, Hyalea, and other Pteropods, Sergestes, sundry Macruran larvae, Worm larvae, Salpae, Aurelia, Geryonia, Ephyra, probably the Ephyra of the Aurelia so common in the Maldives, and which we also saw on our way from Colombo to Aden, two species of Diphyes, and many young Fishes.

From a surface haul while at anchor off Kagi, northern extremity of North Male, we obtained a few swimming Trematods, Sagittae, Pteropods, among them a Tiedemannia, masses of a very large species of Copepod, Crustacean larvae, both Macrurans and Brachiurans, Sergestes, Thrichodesmium, Geryonia, and Aglaura.

From a surface hanl at our anchorage off Ariadn we obtained only a few Copepods and larvae of Macrurans and Brachiurans, Thrichodesmium and many pelagic Algne.

In a surface hanl off Turadu (South Malosmadulu), we obtained many Sagittae, small Crustacean larvae, Sergestes, Styliola, two species of Cunina, Eutima, Oceania, Thrichodesmium, Collozoum, and two species of Diphyes.

1 The abundance of Pteropods in all the tows is rery marked, and probably accounts for the Pteropod ooze found in the atolls of the Maldives. 
In a surface haul off Anguretin (North Malosmadulu), we obtained many Sagittae of all sizes, Sergestes, Crustacean larvae, masses of spores of Algae, and of Thrichodesminm, very many Copepods of a small species, and a great number of Geryonia, and of Eutima.

- At ten in the morning we made a surface haul about halfway between Miladummadulu and Makunudu. The sea was smooth with a bright sun shining, and the water was swarming with life. We collected a great number of Porpita, among them a few very diminutive ones, a colossal Cestum with bright yellow pigment at the extremity of the flappers, Globigerinae, Halobates, young Flying Fish, Diodon, Balistes, and Mollusks; Sergestes, masses of a large blue Copepod, large blue Shrimps, young of Physalia, many different species of floating fish eggs, Sagittae, Sargassum, and Thrichodesmium.

We found a species of Aurelia in great abundance in the northern part of Tiladunmati, specially at our anchorage off Hanimadu, and in the northem Maldives. It is found as far south as Addu.

Off Timarafuri Pass (Kolumadulu) we made three hauls with the tow net in fifty, one hundred, and one hundred and fifty fathoms. We obtained free swimming Amphioxus larvae, perhaps the young of some pelagic species. It seems to be the same larva as that collected by Gardiner in the south of Miladummadulu Atoll and in Fadiffolı Atoll.' The net also contained hosts of Hyalea, Atlanta, Criseis, Cuvieria, Styliola, Phyllosoma, Hyperia, three species of Siphonophores, two species of Medusae, huge Sagittae, Sapphirina, Sergestes, brilliantly colored Macrurans, Oxyrhynchus, large blue, red, and small light-brown Copepods, and numerous large Appendiculariae.

About two miles west off Kandudu Pass (Kolumadulu), we made a pelagie haul in about seventy fathoms. We obtained masses of Copepods, Sagittae, Pyrosoma, Macruran and Brachinran larvae, Sergestes, Collozoum, Aglaura, Rhopalonema; a remarkably large transparent Zoea with a huge carmine patch, Oxyrhynchus, transparent, Syllis-like Amnelids, Diphyes, and two other genera of Siphonophores, Sapphirina, Atlanta, and Spirialis.

1 C. Foster Cooper Cephalochorda, p. 354, Pl. XVIII., fig. 3, Part I. Vol. II. J. S. Gardiner, Fauna and Geog. of the Maldive and Laceadive Archipelagoes, June 15, 1903. 
At anchor in Kolumadulu off Kandudu we obtained from the surfaee a number of large-sized Appendiculariae in their houses, Mnemiopsis and Aglaura, small Isopods, Sagittae, Collozonm, and many Crustacean larvae.

At anchor in Felidu Atoll off Buri Hura, we obtained from the surface Sagittae, Copepods, a large species of Appendicularia, Crustacean larvae, both Macrurans and Brachiurans, a young Turris-like Medusa and Thrichodesmium.

While crossing the Veimandu Channel (between Kolumadulu and Haddummati) in a dead ealm, we passed a great number of flying fish: they conld, as a rule, rise but little; the tail, or the pectorals and tail, both tonched the water as they skimmed along. In the former ease they left a line of a single series of rings, lapping more or less, formed by striking of the tail at regular intervals. In the second ease the contact of the tail and fins formed three lines of rings which interfered in a great many ways, and in both eases left the delicate rings thus formed to disappear gradually long after the flying fish had sunk below the surface.

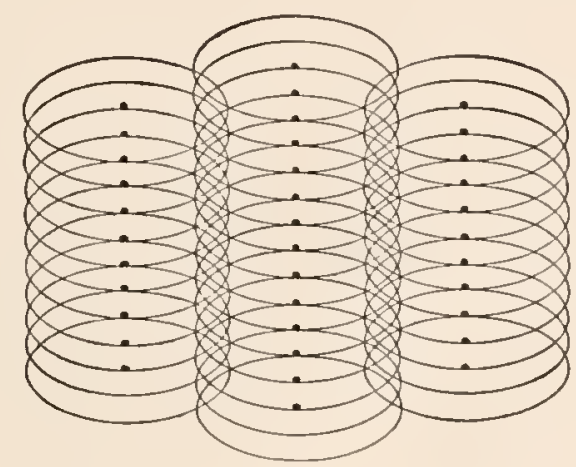

Track of Flyivg Fisi (tail and fins).

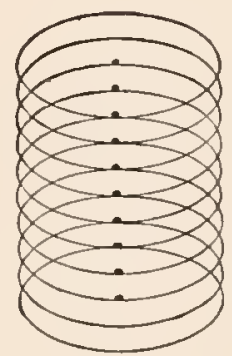

TaIL Track.

In the Veimandu Channel we also passed a great number of Eutimas and of Aurelias, the same speeies we have met with before.

We made two pelagic hanls off the sonthern entrance to Haddummati in one hundred fathoms, and obtained many Sagittae, a few large red Copepods, Collozoum, Rhopalonema, and parts of Medusae, fragments of Diphyes, Sergestes; numerous larvae of Crustaceans, both Macrurans and Brachiurans, Thrichodesmium, Tomopteris, and Alciopa. 
At our anchorage off Funadu (South Haddummati), just before sunset we found the water swarming with Sapphirinae; when gathered in a jar they produced the most beautiful effects from the variety and intensity of the metallic colors reflected by them while swimming about. A large species of Eutima and a species of Berenice were also abundant at this locality. We found the Sapphirina and Eutima again swarming round the ship early in the morning.

At our anchorage off Funadu (south part of Haddummati), we made a most successful surface haul. It was specially marked for the large number of Medusae it contained; there were Stomobrachium, Ephyrae, Hybocodon, a Medusa allied to Gonionemus, Geryonia, Glossocodon, many Styliolas, a number of Halobates, young of Ianthina, fragments of Ctenophores, Diphyes, Veligers, Sea-urchin larvae, Sagittae and Copepods in great number.

In a haul made later in the evening we collected only a few Copepods, Sagittae, Crustacean larvae, and Appendiculariae.

In a surface haul off the south pass of Haddummati, we obtained a great number of Crustacean embryos, both Macrurans and Brachiurans, Sagittae, Salpae, Sapphirinae. Two species of Diphyes, Styliola, Spirialis, Appendicularia, and a few Copepods. Salpae were very abundant in the lagoon as well as a species of Aurelia, which we found everywhere in the Maldives and in the Indian Occan, all the way from Ceylon to Aden. In another surface haul, at our anchorage, in the southern part of Haddummati we obtained Zygodactyla, numerous Halobates, very many Aureliae, and small Copepods shining like Sapphirina.

We made a haul off Dandu (Suvadiva) and collected fine large transparent Macrurans, Sergestes, larvae of Crustaceans, among them a huge Megalops, masses of Copepods, large transparent Syllis-like Annelids, Tomopteris, with colossal lateral appendages; Sagittae, Salpae, Beroë, Ocyroë, Cydippe, Mertensia, Bolina, Geryonia in all stages, two species of Diphyes, Tima, Dipurena, Cunina, Aglaura, Zygodactyla, Stomobrachium, Oceania, Circe, Ephyra, and Rhopalonema.

We made a pelagic haul off the Gan Channel (Suvadiva), in twenty-five fathoms, with poor results. 
We made a surface haul at our anchorage off Gadu (south part Suvadiva), and obtained Sagittae, Diphyes, young Fishes, Collozoum, Crustacean larvae, Salpae, and Thrichodesmium.

In a surface haul at our anchorage off Gang (Addu), we obtained Sagittae, Sergestes, Copepods, Crustacean larvae, Collozoum.

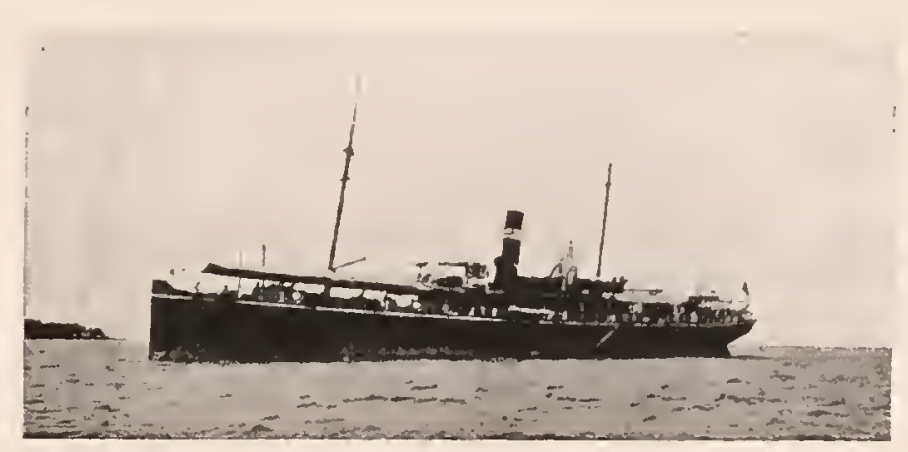

B. I. S. N. Co. S. "AMra." 



\section{N D E X.}

Adago, 107, 109

Addu, 145 , Pls. 1,$6 ; 8 c$, figs. 21,$23 ; 76,77$, fig. 2 Absence of islands in lagoon of, $14 i$

Bottom deposits of, 154.

Connection with Chagos Archipelago, 6

Corals on lagoon slope of, 148

Gardiner on Addu, 147, 148

Growth of corals in, 148

High shingle beach at, 146

In Equatorial region, 145

Isolation of, 145

Lagoon encroaching on land of, 147

Position of islands of, 147

Resemblance of, to Pacific reefs, 145

Shape of, 146

Temperature of lagoon of, 150

Vegetation of, 146

Addu Ridge, 6

Agatti, 5

Aidu, 60, 1'. 22, fig. 1

Akirifuri, 51

Bays of, 51

Vegetation of, 51

Alifuri, 71

Aligau, 73, PI. 33, fig. 2

Vegetation of, 73

Alimata, 117

Androth, 5

Anghenufuri, 57, 65

Lagoon of, now filled, 65

Anguretin, 71

Vegetation of, 71

Ari, 103 , Pls. 1,$4 ; 8 b$, figs. 12,$14 ; 8 c$, fig. $25 ; 55$, fig. $2 ; 56-58$, fig. 2

Bottom deposits of, 153

Bottom of lagoon of, 104

Changes in islands and rings of, 104, 105, 107

Depth of lagoon of, 103

Maldivian characters of, 103

Northern part of, open, 107

Temperature of lagoon of, 149

Trend of faros of east face of, 103

Ariadu, 105, Pl. 55, fig. 2

Atolls, number of, in Maldives, 1

Description of the, 35
Bassas de Pedro, 5

Baura, 80, 97, Pl. 49, fig. 1

Distinct islands of, 97

Beramundu, 10l, Pl. 55, fig. 1

Bilifuri, 91,

Coral patches on rim of, 92

Great size of faro of, 92

Small pass into lagoon of, 92

Bitra, 5

Bodu Faro, 66

Bodu Mandu, 87, Pl. 40, fig. 1

Junction of islands of, 87

Lagoon of, nearly filled, 87

Boilers and faros, 42

Bomasdu, 87, Pl. 39, fig. 2

Shallow sink of, 87

Steep bcaches of, 87

Bottom Deposits of, 152

Addu, 154

Ari, 153

Fadiffolu, 152

Haddummati, 153

Kolumadulu, 153

Miladummadulu, 153

Mulaku, 153

North Male, 152

North Malosmadulı, 152

South Malosmadulu, 152

Suvadiva, 153

Tiladummati, 153

Breyfasdu, 87, Pl. 39, fig. 1

Wasting of, 87

Bundusi, 47

Buri Hura, 116

Byramgore, 5

Cardamum, 5

Cherbaniani, 5

Chetlat, 5

Cooper, C. Foster, on Cephalochorda, 156

Cora Divb, 5

Corals in lagoon of North Male, 39

Corals in lagoon of faros, 39

Dambidu, 132 
Dandu, 136, PI. 75

Darwin, Charles, on disseverment of the large Maldive atolls, 10

On South Maldives, 135

On subsidence of Maldives, 84

On the Maldives as a barrier reef of great dimensions, 11

Dedu, 99, 1'l. 51, fig. 1

Defili Faro, 56

Deha Faro, 85

Dehu, 75

Denduni, 84

Diaddu, 137

Didu, 105

Difuri, 36, 38

Digeli, 69

Digeri, 117

Digu Faro, 81,85

Reef flat of, 85

Digura (Ari), 104

Digura (Suvadiva), 141

Dina Faro, 67

Gardiner on velu of, 67

Diyageli, 123, ㄱ. 66

Consolidation of islands at, 1\%:?

Dugati, 105

Dunacoori, 99, P1. 52, fig. 1

Dunikolu, 62

Dureadu, 87 , Pls. 41, 42, fig, 1

Great depth of lagoon of, 88

Vegetation of, 88

Edu Faro, 79, 84, 11. 35, fig. 2

Corals on flats of, 84

Gap separating islands of, 84

Ekasdu, 88, Pl. 42, fig. 2

Central lagoon of, 88

Ekuru Faro, 56

Elicalpeni Bank, 5

Embudn, 62, Pls. 26, 27

Cuttle-fish bones and Spirula on beaclı of, 63

Height of beaches of, 63

Pumice on beaclies of, 63

Ereada, 88, Pl. 43

Dimension of, 88

Early stage of closure of lagoon in, 88

Etingili, 71

Fadiffolu, 73, Pls. 1,$3 ; 8 a$, fig. $4 ; 8 b$, fig. $10 ; 8 c$, fig. $28 ; 33$, fig. $2 ; 34$, fig. 1

Absence of rings in, 76

Compared to other Maldive atolls, 75

Corals on western horn of, 76

Dimensions of, 74

Exposure of, to monsoons, 77

Lagoon reefs of, 74
Fadiffolu - Continued

Resemblance of, to Pacific atolls, 74

Sontheastern reef flat, 76

Southwest face of, 75

Trend of coasts, 76

Velus of, 74

Western horn of, 75

Fahala, 122

Coalescence of islands at, 122

Faidu, 76, 91

Farna, 109 ; 1'ls. $59 ; 78$, fig. 1

Faro Doru, 72

Faros of North Male, 36, 38

Bottom deposits of, 152

Coalescence of adjoining, 39

Depth of lagoon of, 40

Origin of large, 40

Rims of, 39

Temperature of lagoon of, 150

Farukolu, 89

Feartu, 101, P1. 61, fig. 1

Fehendu, 54, Pl. 19, fig. 2

Felidu Atoll, 114, Pls. 1, 4, 5; $8 b$, figs. 15, 16

Bank of angular boulders in lagoon of, 116

Closed periplery of, 117

Corals on reef flats of, 117

Faros on outer faces of, 115

Irregular outline of, 114

Islands of, 117

Lagoon cusps of, 115

Narrow passes into, 115

Passes of east face of, 117

Temperature of lagoon of, 150

Femfuri Faro, 57, 66

Fengbu Hurah, 72

Filadu, 80, 98, Pl. 50, fig. 1

Connecting ridge of, 98

Lagoon reef of, 98

Secondary lagoon of, 98

Fiori, 138

Fivaku, 91

Flying fish, track of, 157

Fua Mulaku, 145

Funadu (Haddummati), 129

Funadu (Suvadiva), 141

Furadu, 107, l'l. 58, fig. 1

Furena, 37

Furnadu, 8!, Pl. 44, fig. 1

Small lagoon of, 89

Furudu, 54

Wasting of, 55

Furuwari, 66

Fusmundu, 68

Gadu (Haddummati), 129

Gadu (Suvadiva), 139 
Gafuri, 99

Gaha Faro, 53, Pls. 1,$3 ; 8 a$, figs. 6,$8 ; 8 b$, fig. 11 An atoll like Pacific atolls, 53 Free circulation of sea over reef flats, 53

Galandu, 102

Gallandu Channel, 34, 100

Gan (Suvadiva), 139

Gan (Addu), 147, Pls. 76; 77, fig. I

Gang, 130

Gardiner, J. Stanley, On beach sandstone, 106 On bottom in Maldive atolls, 50 On changes at Fadiffolu, 73

On cbanges at Haddummati, 127

On changes at northeast liorn of Addu, 147

On changes at Suradiva, 144

On changes at Turadu, 62

On changes in Kolumadulu, 122

On changes in North and South Nilandu, 108

On changes in South Nilandu, 110

On chaoges of faros in Ari, 105

On comparison of Moresby's Cliart of North

Malosmadulu with his sketches, 67

On depth of Suvadiva lagoon, 143

On elevated reef rock of South Malosmadulu, 61

On enlargement of velus, 67

On estimate of land and water area of Addu, 148

On Farukolu and Furnadu, 89

On fissure zone in Maldives, 88

On growth of corals at Addu, 148

On growth of individual banks, 67

On Hainbuddu, 87

On islands off Gan, Addu, 147

On Kolumadulu as a ty pical atoll, 134

On Mloresby's Charts, 35

On oceanic condition of Goifurfehendu, 54

On small importance of monsoons on edge of reef, 82

On solution in lagoon of Addu, 148

On soundings in Addu, 148

On soundings across Ariyaddu Channel, 27

On soundings across Wadu Channel, 27

On soundings in central basin, 27

On soundings in channels of Mlaldives, 26

On soundings in North Male, 36

On soundings in Suvadiva, 143

On the filling of Addu, 148

On topography of central plateau, 10

On varying depths of banks of Maldives, 134

On western face of Suvadiva, 143

Globigerina sand, 14

Goadu, 92

Goidu, 54, Pl. 20

Goifurfehendu, 54, Pls. 1, 3; $8 a$, fig. $8 ; 8 b$, fig. 10 ; 19, fig. $2 ; 20$
Goifurfehendu - Continued

Deptl of lagoon of, 54

Exposed to northeast monsoon, 54

Former connection of Feliendu, 54

Furudu on rim flat of, 55

Islands on, 54

Gumati, 101, Pl. 54, fig. 1

Closing of gap of, 101

Guradu (South Nilandu), 114

Guradu (Kolumadulu), 125

Guru, 114

Deep faro north of, 114

Haapai group reefs, 2

Haddummati, 127, Pls. 1, 6; 8c, figs. 20, 22 ; 67-70; 77, fig. 1.

Bays enclosing part of lagoon of, 131

Belongs to Pacific atoll type, 128

Bottom deposits of, 153

Clear of islauds, 128

Corals on lagoon slopes of, 129

Depth of, 128

Effect of monsoons on outer faces of, 130

Formation of lagoons of, 133

Islands on west face of, 128

Large triangular northeast horn of, 132

Narrow boulder belt of, 130

Narrow gap at Gang in, 131

Reef flats of, 133

Temperature of lagoon of, 150

Vegetation of, 129

Hainbuddu, 87

Hanikandu Faro, 64

Hanimadu, 96

Connecting ridge of islands of, 97

Narrow atoll of, 97

Hanlus, 141

Vegetation of, 111

Haru Hura, 114

Islands on flat of, 114

Hatedu, 136

Hauwandu, Pl. 54, fig. 1.

Havaru, 138

Hekara, 109, Pl. 60, fig. 1

Boulders at, 109

Hembadu, 48

Hibadu, Pl. 74, fig. 2

Hirilandu, 126

Hitadu (Addu), 146

Hitadu (South Malos), 61

Hitadu (Haddummati), 128, 129

Hitty, 48, Pl. 17, fig. 2

Hoholundu, 68

Hondedu, 138

Hoskyn, Commander, 1

Huludali, 111 
Huludu (Addu), 146

Huludu (Miladummadulu), 84

Hulule, 37, Pls. 10, 11

Huluwa, Pl. 62, fig. 1

Huluwarolu, 137

Huni Faro, 60

Huradu, 136

Hura Mula, 136

Hurudu, 57

Hute Kolu, 114

Hydrography of the Maldives, 1, Pls. 1-8c

Thavandiffulu Atoll, 100, 1'ls. 1, 2; 8 a, figs. 1, 3 ; 54,55 , fig. 1

Irregular shape of, 100

Ihavandu, 101

Imma, 37

Inamadu, 70

Inawari, 73

Isdu, 132, Pl. 69, fig. $2 ; 70$

Jeweller's Islands, 111, 1'1. 78, fig. 2

Kabafaro, 90

Kadu, 130

Kagi, 51

Meagre vegetation of, 51

Kakuni, Pl. 68

Kalpeni, 6

Kandimas, 112, Pls. 62, fig. 2 ; 63, 64, fig. 2

Kandudu (Kolumadulu), 126

Kandudu (Suvadiva), 138

Kandufuri, 126

Kandu Huludu, 137, 1'l. 74, fig. 1

Kandute, 92

Exposed to southwest monsoon, 93

Kanifuri, 75

Corals off, 76

Exposure of, to soutliwest monsoon, 76

Karaidu, 132, Pls. 69, fig. 1; 77, fig. 1

Karawatti, 5

Karema, 83

Wasting of, 84

Corals on rim tlats of, 84

Kari Faro, 65, Pl. 29, fig. 1

Kaŗidu (Middle Malos), 64

Karidu, 55, Pl. 21

Compared to Maldivian atolls, 59

Compared to Pacific atolls, 59

Faro is an atoll, 58

Forest trees in centre of island of, 55

Lagoon of, partly filled, 56

Opening into lagoon of, 56

Wasting of island of, 56

Keadu, 116
Kelai, 79, 80, Pl. 50, fig. 2

Entranse to lagoon of, 98

Kendikolu, 79, 86

Mangroves at, 86

Sink of, 80

Kendu, 57, 64, Pl. 29, fig. 2

Kiadu, 64

Kiadufuri, 64

Kiltan, 5

Kimbudu, 126

Kofenbe, 91

Kolufuri, 121

Kolumadulu, 122, Pls. 1, 5 ; 8 b, figs. 17, 18 ; $8 c$, fit. $20 ; 66$

Bottom deposits of, 153

Deptlı of, 122

Consolidation of islands at, 123

Interior basin of, sliut off from sea, 124

Line of angular boulders on east face of, 123

Position of islands in lagoon of, 122

Structure of outer faces of, 125

Temperature of lagoon of, 150

Vegetation on sea face of, 125

Komandu, 86, Pl. 36, fig. 2 Wasting of, 87

Konipafuri, 112

Kotafuri, 69

Wasting of, 70

Kuda Kura, 70

Kuda Mandu, 87, 1'l. 40, fig. 2

Kudahitty, 47, 1'l. 17, fig. 1.

Kudu, 142

Kukuludi Faro, 67

Gardiner on clanges at, 67

Kuludu Faro, 89, 1'ls. 37, 38; 79, fig. 3

Kumberidu, 95, 1'l. 48, fig. 2

Kunahaudu, 120

Kumfinadu, PI. 3

Kurada, 144

Kurafuri, 104

Kuraid u, 91

Kurangdu, 74

Kuredu, 76

Kureli, 120, Pl. 65

Boulders on west face of, 120

Kurimbe, 95

High beaches of, 95

Labadu, 141

Laccadive Archipelago, 5, Pl. 8

Laccadives, Plateau of the, 7

Soundings among the, 6

Survey of the, 1

Lofara, 85

Lohi, 74

Wasting of, 74 
Lowalafuri, 74, Pl. 34, fig. 1

Encroachment of shingle on beaches of, $7 . t$

Mabadu, 132

Mabaru, 60, Pl. 22, fig. 2

Madali, 111

Maddedu, 85, PI. 36, fig. 1

Madidu, 91

Madu, PL. 3

Maduni Faro, 56, 67

Maduwari, 61, P1. 25

Ma Faro (Miladummadulu), 79, 86

Ma Faro (Malosmadulu), 56, 66

Gardiner an velu of, 67

Mafilefuri, 75

Mafuri (South Male), 114, Pl. 79, fig. 2

Mafuri (Suvadiva), 135, Pls. 71, 72; 79, fig. 1

Magudu, 107

Mahafai, 95 , 1's. 48 , fig. 1 ; 49, fig. 2

Maimbudu, 112

Makandudu, 89

Sink of, 89

Makara, 70

Makunudu, 71, Pls. 1, 2; 8 a, fig. 7; 31, fig. 2; 32; 33 , fig. 1

Boulder wall of, 73

Depth of lagoon of, 72

Dry reef of, 72

Elevation of, 72

Makunudu Island, 72

Maldive Islands,

Absence of elevation in, 124

Bottom deposits of lagoons in the, 152

Character of atolls of the, 120,124

Changes in the, going south, 120

Contrast of outer rims of the, to Pacific atoll rims, 142

Description of atolls in the, 35

Depth of channels between eastern and western cliain of the, 3

Dip of plateau of the, 3

Distance from Ceylon, 2

Double chain of the, 3

Limits of nonsoons in the, 8

Pelagic fauna of the, 153

l'lateau of the, 9

Single line of the, 3

Male Faro (South Nilandu), 112

Male Island, 41

Malosmadulu Plateau, 56, Pls. 1,$3 ; 8 a$, fig. $5 ; 8 b$, figs. 9,$10 ; 8 c$, fig. $28 ; 22-30 ; 31$, fig. 1

Comparison of, with Goifurfeliendu, 57

Deepest sounding in lagoon of, 57

Deep passes on east face of, 56

Faros in basin of, 57

Faros of, comparesl to atolls, 58
Malosmadulu Plateau - Continued

Faros witl wide reef flats on, 56

Formation of islands on, 67

Position of faros and islands on, 56

Resemblance of, to Ari, 56

Mamanaga Faro, 66, P1. 30, fig. 1

Mameta, 143

Mamigeli, 101, 105, Pls. 55, fig. 2 ; 50

Manafur, 101

Mandu (Ari), 106

Mandu (Haddummati), 132

Manganese nodules, 24

Marandu, 100

Mararxekellu, 57, 65

Maregiri, 66, Pls. 30, fig. 2; 31, fig. 1

Dunes of, 67

Maro, 74

Matiwari, 105

Matoda, 138

Mavaidu, 91

Mavaru, 128, PI. 67

Mavila, 85

Mawa Faro, 56

Mawafuri, 109, Pl. 61, fig. 2

Medu, 57, 69

Vegetation of, 69

Height of beaches of, 69

Megeli, 63

Island not on chart of, 68

Middle Malosmadulu, 64, Pls. 1, 3; 8 b, figs. 9, 10 ; 29 , fig. 1

Clianges in islands of, 65

Islands of, dished, 65

Midu, 146

Miladummadulu, 83, Pls. $1,2,3 ; 8 a$, figs. 4, 5, 7 ; 34 , fig. $2 ; 35-44 ; 79$, fig. 3

Bottom deposits of, 153

Central gap of, 91

Crescentic islands on east iace of, 86

Exposed to southwest monsoon, 84

Formation of atolls from crescentic islands in, $8 \vec{i}$

Inner line of island near east face of, 80

Islands on east face of, steep to, 88

1slands with ligh beaches in, 85

Milandu, 89

Wasting of, 89

Dumb-bell shape of, 90

Miledu, 100, Pl. 52, fig. 2

Minikoi, 7

Mirufuri, 35

Moresby, Commander, Survey of Maldives, 1

Muadn, 94

Spits off east end of, 91

Muduwari (South Malos), 64, 1'1. 28, fig. 2

Muduwari (North Malos), 68

Muheri, 95 
Muladu, 101, Pl. 54, fig. 1

Mulaku, 118, Pls. 1, 5; 8 , figs. 13, 15, 18; 64, fig. $1 ; 65$

Absence of islands on west face of, 121

Bottom deposits of, 153

Corals on inner flats of, 121

Depth of lagoon of, 118

Faros and rings in lagoon of, 119,120

Faros in outer faces of, 119

Reef flats on east face of, 119

Resemblance of, to Pacific atolls, 119

Sinilar to atolls of single line, 119

Transverse dikes of boulders at, 120

Munafuri, 128

Muradu (West Tiladummati), 82, 93, Pls. 45; 46, fig. 1

Change in islands of, 98

No pass into lagoon of, 94

Muradu (Northeast Tiladummati), 95, 1'. 48, fig. 1

Murdu, 102

Murray, Sir John,

Bottom deposits of the Maldives, 152

Mutalifoori, 63, Pl. 24, fig. 1

Nadale, 138

Nalandu, 90, Pl. 44, fig. 2

Sink of, bare at low water, 90

Lagoon and sink of, conected, 90

Naguri, 94, 1'ls. 46, fig. $2 ; 47$

Peculiar slape of, 94

Naraka, 126, Pl. 66

Nipafura, Pl. 60, fig. 2

Noliwang Faro, 83, 96

Nomuka group reefs, 2

North Male, 35, Pls. 1, 3, 4 ; 8 a, fig. 6 ; 8 b, figs. 11 , $19 ; 8$ c, fig. $24 ; 9-18 ; 19$, fig. 1

Absence of vegetation on west face of, 52

Bottom deposits of, 152

Bottom of lagoon of, 43,49

Central sink of islands in lagoon of, 44

Corals on faros of, 46

Corals on slopes of island in lagoon of, 44

Depth of lagoon of, 43

Open northern extremity of, 51

Passage of rings to islands in, 47

Passes into, 49

Purity of water of lagoon of, 44

Rings and faros of, $42,45,46$

Soundings in, 49

Temperature of lagoon of, 150

Vegetation of islands of ligoon of, 44

Wooded islands in, 41

North Malosmadulu, 65, Pls. 1, 3; 8 a, fig. $5 ; 8 b$, fig. $9 ; 8$ c, fig. $26 ; 30 ; 31$, fig. 1

Bottom deposits of, 152

Depth of, 71

Dunes : $t, 67$
North Malosmadulu - Continued

East face of, 63

Enlargement of velus of, 67

"Jungle of reefs" in, 67,68

Large islands on east face of, 65

Open at northern extremity, 65

Sand eneroaching on vegetation of, 67

Soutliwest part of, clear, 66

Temperature of lagoon of, 151

Vegetation of east face of, 71

Vegetation of islands of, 68

Wide passes into, 66

North Nilandu, 107, Pls. 1, 4, 5; 8 b, fig. 14; 59-61 ; 78 , fig. 1

Banks witl velus in, 108

Channel between South and, 108

Cusps on west face of, 108

East face of, 108

Elevation of parts of outer rim of, 109

Islands in interior of, 107

Rim of, 107

$\mathrm{Nu}, 91$

Well-defined reef platforms of, 110

Numara, 91

Nuriwari, 96

Olngeri, 61

Pelagic Fauna of the Maldives, 155

Peremul Par, 5

Phares, 129

Piti Bank, 5

Powell Islands, 58, 71

Isolated atolls of, 58

Powell, Lientenant, survey of Mlaldives, 1

Prentice, Lientenant, on disappearance of un island in the Maldives, 84

Pteropod ooze, 24

Rakidu, 115

Narrow lagoon along, 116

Rasdu, 102, Pls. 1, 4

Depths of atoll of, 102

Rasmadu, 70

Roongelly, 69

Sesostris Bank, 5, Pl. 8

Soundings taken by the "Amra," 12, 29, Pls. 1-8c $\Lambda$ cross Ariyaddu Cliannel, 21, 30, Pl. 8b, fig. 14 Across Central Basin of the Maldives, 13, 19, 30 , 33, Pls. $8 a$, flg. 5 ; $8 b$, figs. 12,$13 ; 8 c$, 28

Across Equatorial Channel, 25, 31, Pl. 8 c, fig. 23 Across Gallandu Channel, 12, 34, Pl. $8 a$, fig. 3 Across Fadiffolu to Miladummadulu, 16, 34, Pl. $8 a$, fig. 4

Across Fulidu Channel, 20, 32, Pl. 86 , fig. 16 
Soundings taken by the "Amra" - Continued

Across Goifurfehendu to South Malosmadulu, 15,33 , Pl. 8 b, fig. 10

Across Kardiva Channel, 16, 33 , I'l. 8 b, fig. 11

Across Malosmadulu Channels, 15 , Pl. $8 b$, figs. 9,10

Across North Mlale to Gaha Faro, 17, 32, Pl. $8 a$, fig. 6

Across One and half degree Channel, 24, 31, Pl. $8 c$, fig. 22

Across Veimadu Channel, 23, 31, P. $8 c$, fig. 20

Across Wadu Channel, 18, 29, 1'l. 8 b, fig. 19

Between Kolumadulu and South Nilandu, 22, $32, \mathrm{Pl} .8$ b, fig. 17

Between Miladummadulu and Makunudu, 12, 34, Pl. $8 a$, fig. 7

Between Miladummadulu and North Malosmadulu, 13, 34, Pl. 8 u, fig. 5

Between MLulaku and Kolumadulu, 22, 30, Pl. 86 , fig. 18

Between Rasdu and Ari, 102, I'l. 4

Between South Male and Ari, 29

Between Toddu and Rasdu, 102, Pl. 4

East of Kelai, 12, PI. $8 a$, fig. 2

East of South Male, 18, PI. $8 c$, fig. 27

From Gahı Faro to Goifurfehendu, 14, 33, Pl. $8 a$, fig. 8

From Mulaku to Wataru and Felidu, 21, 32, Pl. $8 b$, fig. 15

From Murdu to Colombo, 26, 24, Pl. 1

From Nortl to Soutl Nilandu, 22

Off oceanic faces of the Maldives, 12, 20, 29, 30, $32,34,1$ l. 8 c, figs. 21-27

Off thavandiffulu, 12, Pl. $8 a$, fig. I

South of Addu, 25, 31, Pl. 8 c, fig. 21

West of North Male, 17, Pl. $8 c$, fig. 21

South Male, 113, Pls. 1, 4; 86 , figs. 12, 16; $8 c$, figs. 19,$27 ; 79$, fig. 2

Deep lagoon on east face of, 114

Dimensions of, 113

Similarity to North ILale, 113

South Malosmadulu, 59, Pls. 1, 3; 8 , fig. $10 ; 8 c$, fig. $28 ; 22-28 ; 29$, fig. 2

Bottom deposits of, 152

Changes in southeastern horn of, 61

Corals on rim flats and lagoon slopes at, 63

Exposure of, to northeast wonsoon, 60

Sink in islands of, 63,64

Size of islands of, 60

Slope of east face of, 60

Temperature of lagoon of, 151

Vegetation of islands of, 60

Wide passes of southeast face of, 60

South Nilandu, 110 , Pls. 1,$5 ; 8 b$, figs. 13,$17 ; 62$ 64 , fig. $2 ; 78$, fig. 2

Distribution of basks and faros in, 110
South Nilandu - Continued

Formation of islets iv, 113

Formation of lagoon on southeast face of, 111

Jewellers Islands in, 111

Nullipores at, 113

Outliers of coral reef rock in, 112

Passes separating outer faros of, 112

Suheli Par, 5, P1. 8

Surveys of the Maldives, 1

Suvadiva, 134, Pls. 1,$6 ; 8 c$, figs. 22, 23; $71-75$; 79, fig. 1

An open oceanic atoll, 143

Bottom deposits of, 153

Boulders on flats of, 139

Climate of, 136

Comparison of, with Pacific atolls, 135

Corals in passes of, 141

Corals on lagoon slopes of, 135

Depth of, 138

Extent of land rim of, 140

Formation of bays in, 187

Faros on parts of outer faces of, 134

Gaps between islands of, 139

Great size of, 134

Islands and banks in lagoon of, 135

Narrow reef flats of, 135

Reef flat of northeast horn of, 142

Resemblance of, to Marshall atolls, 135

Shallow passes into, 138

Temperature of lagoon of, 151

Vegetation of, 141

Width of passes of, 140

Tahwahtah, 69

Telin Faro, 67

Temperature of the lagoons, 149

In Addu, 150

In Ari, 119

In Fadiffolu, 150

In Felidu, 150

In Haddummati, 150

In Kolumadulu, 150

In Mulaku, 149

In North Male, 150

In North Malosmadulu, 151

In South Malosmadulu, 151

In Suvadiva, 150

In Tiladummati, 151

Tiladummati, 93 , Pls. 1, $2 ; 8 a$, figs. 2,$3 ; 45-53$

Artificial boundary of, 93

A tolls of northeast horn of, 98

Bottom deposits of, 153

Changes in outline of islands of, 93

Coalescence of islands of, 98

Crescent-shaped islands of, 98

Effect of moonlight on reef flats of, 97 
Tiladummati - Continued

Faros of east and west face of, 96

lslands cluaracteristic of inner waters of, 95

Islands of nortlieru part of, closely packed, 97

Pandanus on northern islands of, 95

Tenperature of lagoon of, 151

Tiladummati-Miladummadulu Plateau, 78 , Pls. 1, 2,$3 ; 8$ a, figs. $2-5,7$; 34 , fig. 2 ; 35-53; 79 , tig. 3

Atolls and faros of, based on separate knoils, 82 $\Lambda$ tolls and faros of, not formed by subsidence, 80 $\Lambda$ tolls of, become islands, 80

Atolls of northeast horn of, 79

Boundary line between, 78

Clange in outlines of islands of, 82

Conpared to southern groups, 78

Condition of, not that of an atoll, 82

Cresccnt-sliaped islands of east face of, 79

Current sweeping into, 82

Faros passing to islands in, 80

Formation of faros of, 80

Formation of separate islands of, 83

Great width of passages of, 81

Islands of interior of, 80

Junction of separate islands of, 83

Motion of islands like that of dunes in, 83

Modifying effect of monsoons on, 82

Open interior waters of, 81

Position of islands on, 78

Shape of, 78

Sniall land area of, 81

Subsidence does not account for formation of atolls of , 81

West face of, 80

Timarafuri, 124

Tinadu (Felidu), 117

Tinadu (Suvadiva), 144

Toddu, 102, Pls. 1, 4

Tolandu, 85

Topography of Indian Ocean, 5, Pls. 7, 8

Tukandu, 100, Pl. 53

Boulders of, 100
Tulagiri, 47, Pl. 16, fig. 2

Tulusdu, 36

Tura, 66

Turadu, 61

Gardiner on changes at, 62

Tuvarn, 121

Uleguma, 101

Vaimandu, 126

"Valdivia" Soundings south of Addu, 6

Vehamafuri, 47

Veimandu Channel, 23, 31, Pl. 8 c, fig. 20

Velengeli, 62, 66

Wadu (North Malos), 57

Wadu (Suvadiva), 139

Waduni, 132

Wagaru, 101

Wakarn, 63

Height of beaches of, 63

Wandu, 70

Wandu Faro, 60

Wani, 112

Warifuri, 79, 80, 99, Pl. 51, fig. 2

Deptls of lagoon of, 99

Islands of, 99

Wataru, 84, Pl. 35, fig. 1

Wataru Reef, 118 , Pls. 1,$5 ; 8$, fig $15 ; 58$, fig. 1

Islets on rim flat of, 118

Narrow entrance into, 118

Reef flats of, awash, 118

Wataru Channel, 21, 32, 118, Pl. 8 b, fig. 15

Watu, 85

Wegeli, 141

Welingandu, 126

Wilingili (North Male), 35, 50

Wiringili (Addu), 146

Wiringili (Suvadiva), 142, Pl. 77, fig. 2

Elevated reef rock at, 162

Yucatan plateau, reefs of, 1 



\section{PUBLICA'TIONS}

OF THE

\section{MUSEUII OF COMPARATIVE ZOÖLOGY \\ AT IIARVARD COLLEGE.}

There have been published of the BuLletin Vols. I. to XXXVIII., and also Vol. XL.; of the Memorrs, Vols. I. to XXIV., and also Vols. XXVIII. and XXIX.

Vuls. XXXIX., XLI. to XLV, of the Bulderin, and Vols. XXY. to XXYII., and XXX. of the Menores, are now in conrse of publication.

A price list of the publicutions of the Musemm will be sent. on "ipplicution to the Libruriun of the Musen of Compuratice Zoiilogy, Cimbrillye, Mass. 

$4 x^{4}-{ }^{4}$

$2 \%$

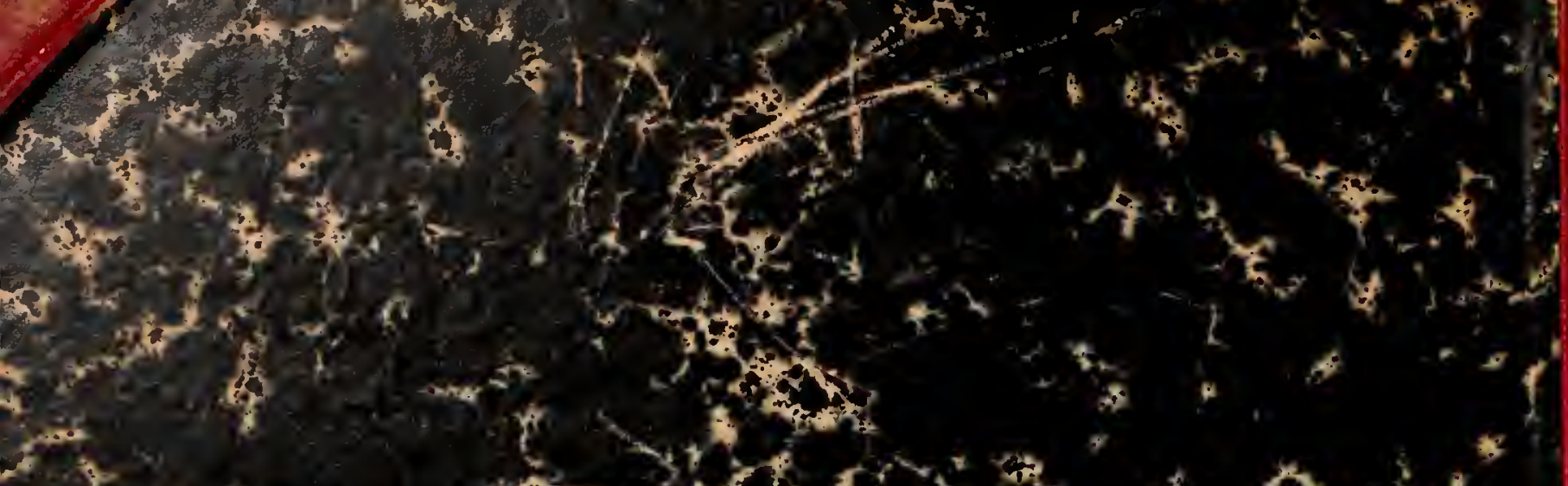









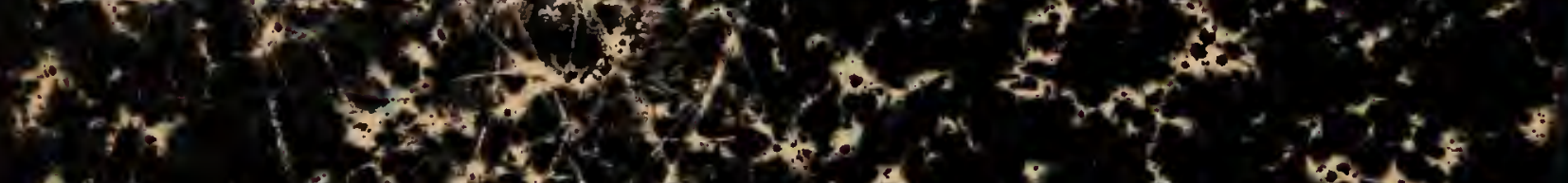

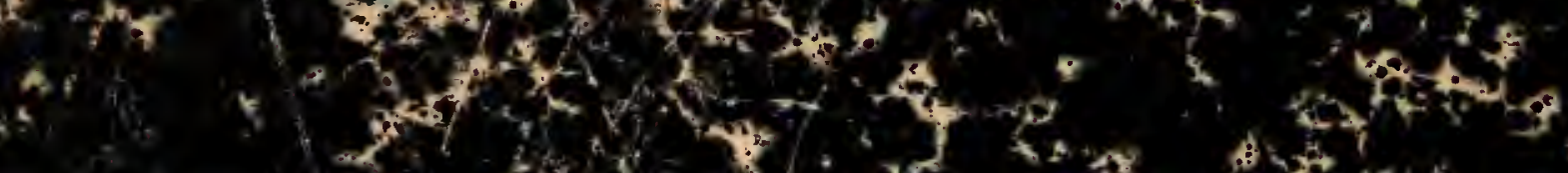

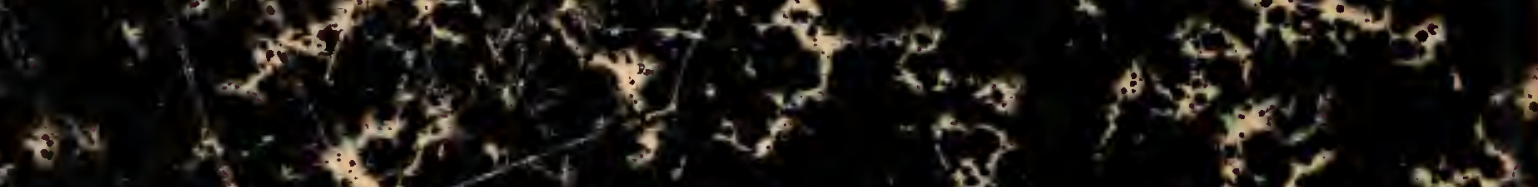

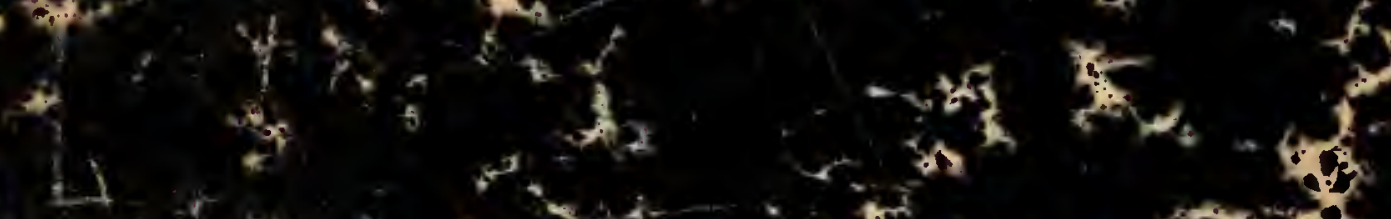

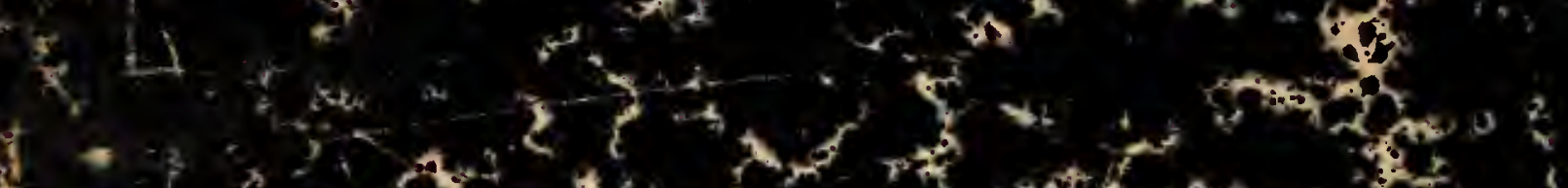

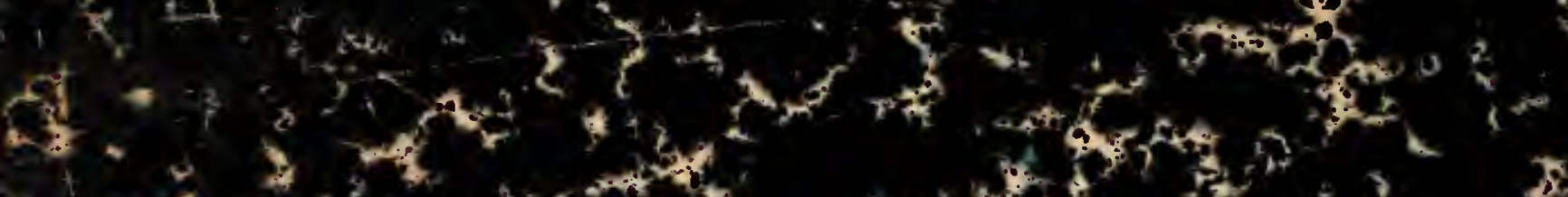

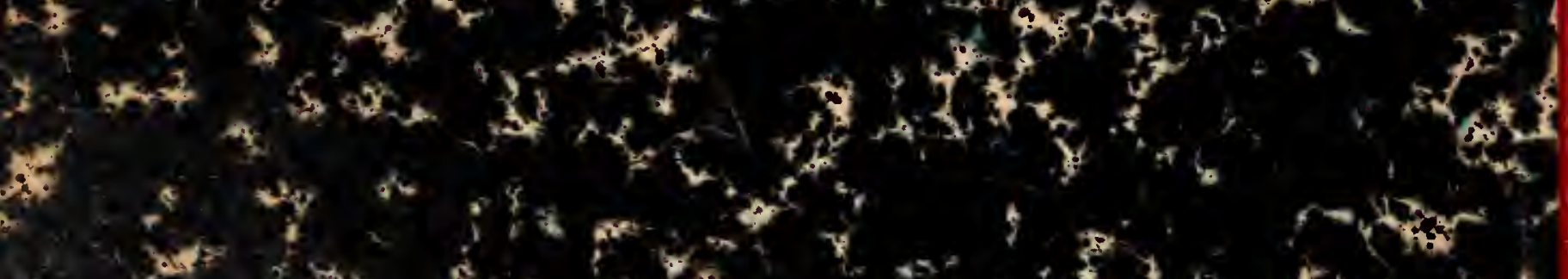

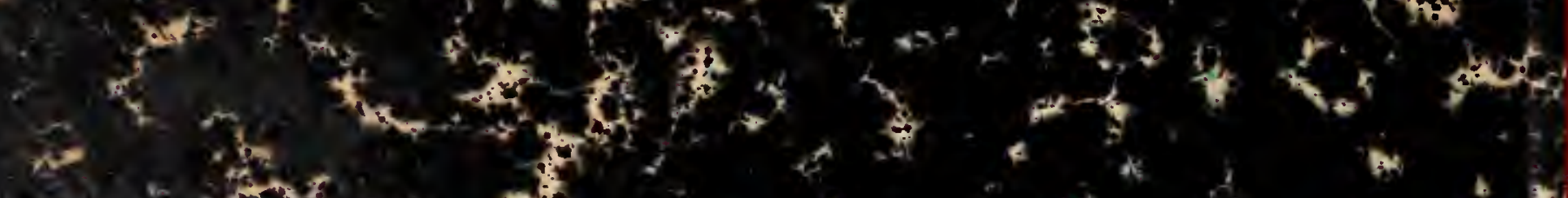

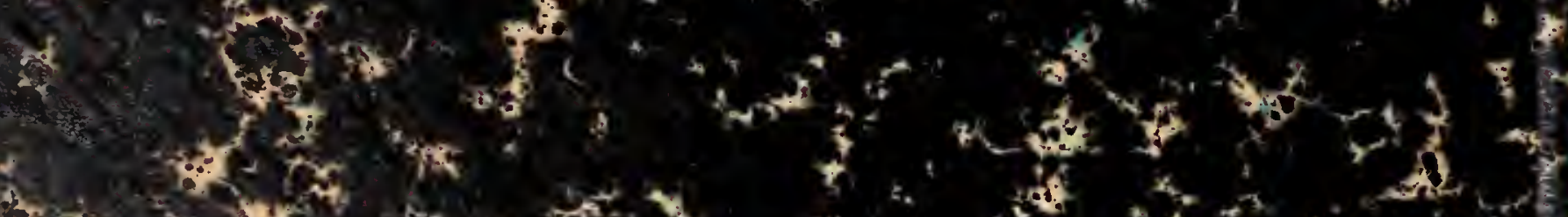

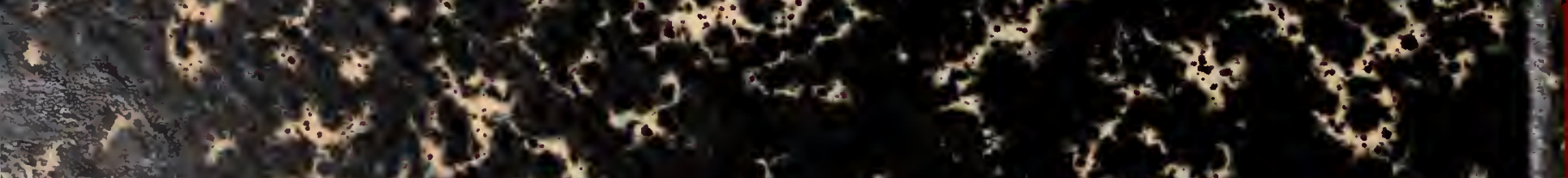



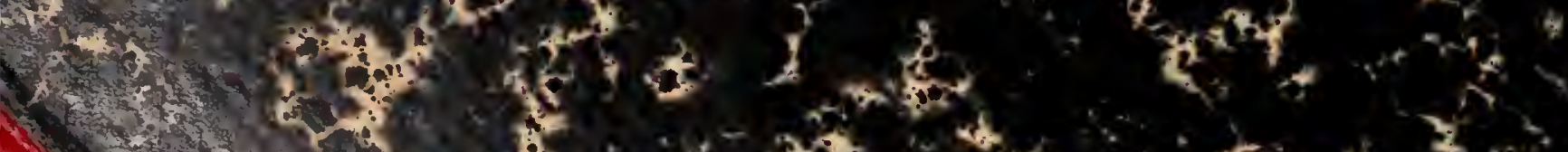

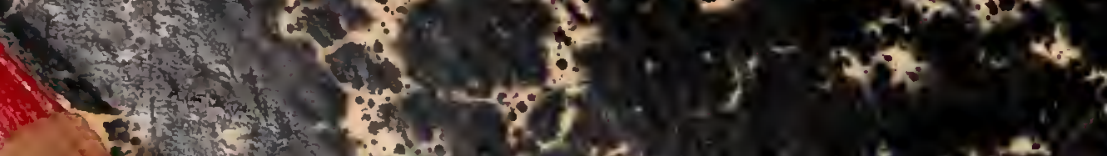

